\title{
Irrigation projects in Iraq
}

\author{
Mukhalad Abdullah ${ }^{1}$ and Nadhir Al-Ansari ${ }^{2}$
}

\begin{abstract}
Iraq has a unique irrigation system since the early history, these systems are functioning through many irrigation projects built over `Tigris and Euphrates Rivers. Irrigation projects include several categories, which are dams, barrages, canals, drains, pumping stations, regulators, and reservoirs.

There are six large dams inside Iraq, 5 are existing in Tigris basin, and one in Euphrates basin, these dams which were built since 1950's are suffering from several issues, like foundation liquefaction, seismic effects, and others.

Tharthar Lake, Habbaniyah Lake, Razzaza Lake, and Southern Marshes are also one of the main projects in Iraq to control flood and storing excess water in some. These lakes serve in protection of the main cities during large floods.

There are also many barrages on Tigris and Euphrates, some of these barrages are part of Tharthar and Habbaniyah projects, while others serving the irrigation projects in Mesopotamia.

On Euphrates, there are several irrigation projects, where the projects upstream Fallujah city are almost small or medium projects irrigated by pumping. Then, in the rest of Euphrates, there are Great Abu Ghraib project, Great Mussayab, HillaKifil, some small projects, and Kifil-Shinafiyah projects. Also, Hilla branch which is the largest branch in Iraq from Euphrates, where this branch is irrigating several irrigation projects.

On Tigris basin, there are Jazeera project irrigated by pumping from Mosul Dam, Kirkuk project that is irrigated from Lesser Zab River, and Diyala are projects. Inside Mesopotamia and over Tigris reach, there are Ishaqi project, Nahrawan project, Middle Tigris projects, Dujailah project, Dalmaj project, and Gharraf Canal projects.

In the middle of Mesopotamian plain, Main Outfall Drain was completed in 1992, this grand drain are serving around 6 million donum of farmlands.
\end{abstract}

Keywords: Dams, Barrages, Irrigation canals, Iraq.

${ }^{1}$ Consultant engineer, Baghdad, Iraq.

${ }^{2}$ Lulea University of Technology, Lulea, Sweden.

Article Info: Received: October 27, 2020. Revised: November 1, 2020.

Published online: November 15, 2020. 


\section{Introduction}

Since the early history, Iraq was known with irrigated agriculture, which was the trigger of civilization. The projects to regulate, store, and distribute water quantities in Tigris and Euphrates Rivers are existing centuries ago. After the establishment of new Iraq in 1921, the wheel moved again to build irrigation mega project, which extends along Iraq from north to south and from east to west.

In this report information was compiled to manifest the water resources projects which include dams, barrages, regulators, pumping stations, canals, drains, reservoirs, and many others.

First, dams and barrages will be demonstrated, then reviewing the irrigation main schemes on Tigris main course, Tigris Tributaries, and Euphrates main course. At the end, a review presented about Main outfall drain and other main drains in Mesopotamia.

\section{Large Dams}

Development Board was first interested in the large dams, Doukan and Darbendhikhan Dams were first constructed during Development Board era. Later, at the second half of 1970s, the interest was coming to front again, where the second batch of dam had built, Hemrin, Haditha, and Mosul Dams. In the 1990s, Adhaim Dam was built. There are still in the agenda, the construction of Bekhme and Makhoul Dams.

\subsection{Mosul Dam}

Studies were initiated to for the dam by Development Board through the companies (Alexander Gibbs \& Partners) and (Munsel Basford and Bafrey), they prepared a study and submitted a joint report in 1953 that included the proposal of two sites near the moonlight village north of Aski Mosul, the proposals included a storage dam with a capacity of 8.7 billion cubic meters, and elevation of $320 \mathrm{~m}$ a.s.l.

Then, the American company Harza was commissioned by Development Board to study the project and it presented the full report in 1960, Harza Company has indicated that the proposed previous sites are not appropriate geologically and proposed two new locations; the first has a capacity of 7.8 billion cubic meters at elevation of $320 \mathrm{~m}$ a.s.l. and the second has a capacity of 13.5 billion cubic meters and elevation of $325 \mathrm{~m}$ a.s.l.

Soviet Company Technopromexport submitted a new study in 1962 and a proposal for a new storage dam with a capacity of 7.7 billion cubic meters at elevation 312 $\mathrm{m}$ a.s.l. Then, Imatran Voima Company was assigned to prepare a study for the proposed dam and it was presented in 1973, the report has been evaluated by Technopromexport and Board of Experts, they both raised notes concerning the dam and the need to intensify geological investigations. Next, the dam construction proposal presented for Hochtief Company to do it in 1974, and after the company review, the agreement did not happen due to the foundations issue of the dam. The 
French company, Solseif, was later commissioned to conduct geological investigations and presented its findings in 1979. Finally, agreement was reached with the Swiss consultants to prepare the dam study, which was presented in 1979 (Adamo, Al-Ansari, et al. 2018; Al-Simawi, 2008).

What has been manifested about studies, where many parties had been involved with an approaching results highlights clearly the sensitivity of Mosul Dam foundations, which resulted that the consulting companies and decision makers to re-examine and study the dam site several times, they convened a final conclusion that the dam underneath has gypsum formations which made a threat to the safety of the dam proposal, the alternative between the site and another of what it takes less remedies, and it will not be possible to find a site far of this negative findings. The length of the dam is $3,600 \mathrm{~m}$, it is and earth fill dam with a clay core. The tallest height of the dam is $100 \mathrm{~m}$ and the operational level is $330 \mathrm{~m}$ a.s.l. The design storage is 11.11 billion cubic meters. The minimum operational level is $300 \mathrm{~m}$ a.s.l., below a dead storage equals to 2.95 billion cubic meters, as the live storage is 8.16 billion cubic meters. The dam has a gated spillway on the left side; the spillway maximum discharge is $7400 \mathrm{~m}^{3} / \mathrm{s}$ at the maximum flooding level of $338.5 \mathrm{~m}$ a.sl. The length of the spillway is 1.013 meters and the width is 50 meters. The flow energy through Flip-bucket end of the spillway which directed the flow $25^{\circ}$ of horizon, Figure 1 Shows a general view of Mosul Dam (Adamo, Al-Ansari et al. 2018; Al-Simawi, 2008; USACE, 2003).

The dam includes 4 power units of Francis turbines on the right side of the dam with a total capacity of $750 \mathrm{MW}$. On the right side also, there are 2 bottom outlets that ensure a minimum discharge of $330 \mathrm{~m}^{3} / \mathrm{s}$ at the elevation of $300 \mathrm{~m}$ a.sl. The dam also includes two diversion tunnels on the right side of the dam shoulder. The project includes a pumped storage hydropower station by storage and pumping, this station aims to meet the consumption during the peak of energy demand without wasting quantities of water. The water is stored in an artificial lake with a capacity of 11 million cubic meters constructed above Taira Hill to the right of the dam, where this plant generates 200 megawatts. There is also within the body of the dam the outlet of the South Jazeera irrigation project, which has not been completed yet, and there is a proposed hydropower station in the outlet route (Adamo, Al-Ansari, et al. 2018; Al-Simawi 2008; USACE 2003). 


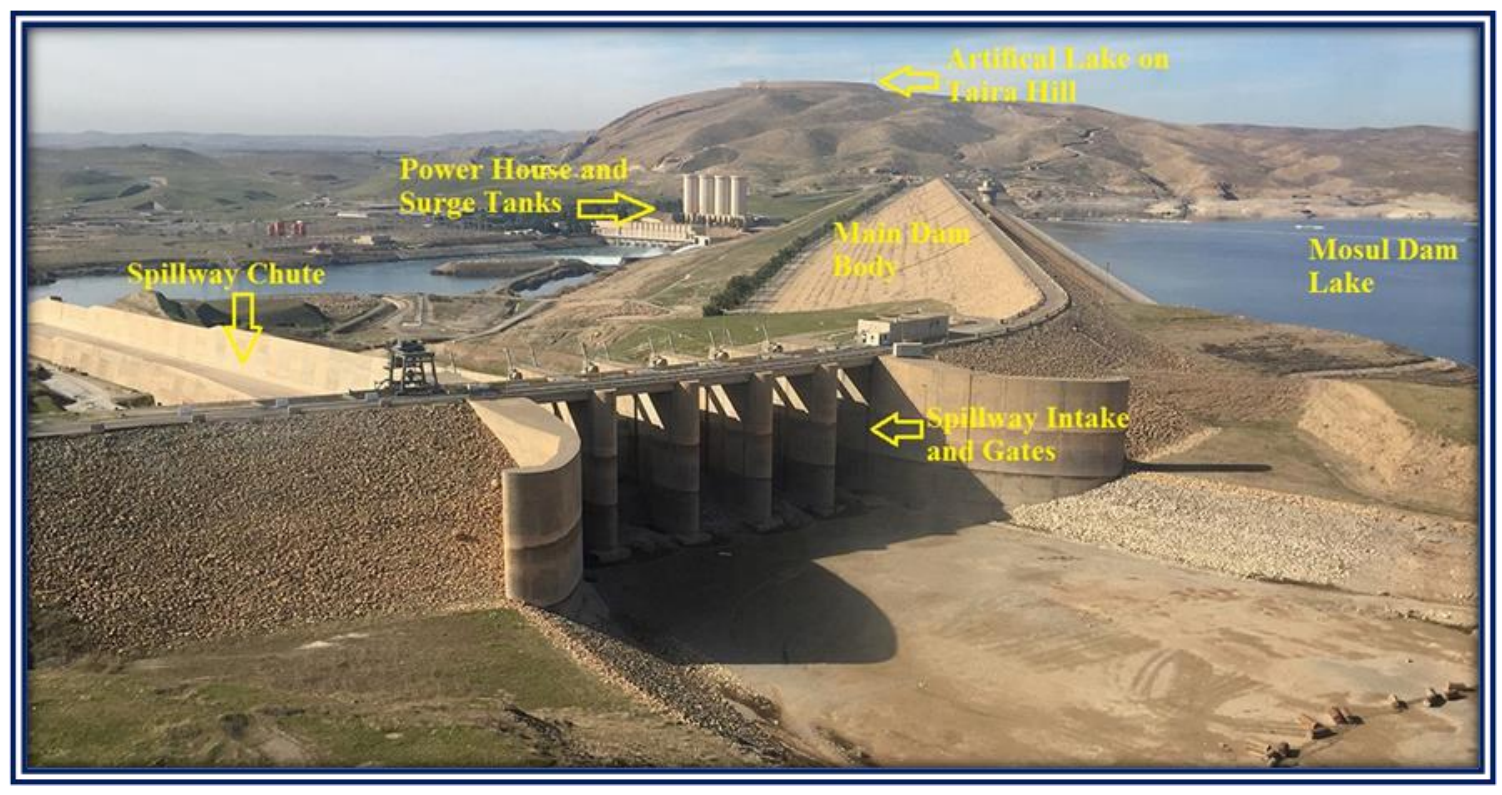

Figure 1: General view of Mosul Dam (Edited by Author). ("Trevi Group Website" n.d.).

Mosul Dam includes as fuse-plug dam on the left side of the main dam, grouting tunnels, electric transformers, piezometers, as well as infrastructure for control, management, grouting and other services. Beneath the main dam, the grouting blanket had been implemented with 20 lines and depths of (25-10m). Further; the curtain grouting were implemented which consists 5 lines, three of them are vertical, and the two on both sides has inclination of $6^{\circ}$, the curtain grouting varies in depth and reaching up to $150 \mathrm{~m}$.(Kelley et al. 2007).

Downstream of the main dam and at a distance of $9 \mathrm{~km}$, the regulation dam was built on Tigris stream to control the high discharges from power plants and ensure a minimum discharge $330 \mathrm{~m}^{3} / \mathrm{s}$. This dam was implemented by Austrian company Allen Union. The length of the regulation dam is $381 \mathrm{~m}$ and the height is $20 \mathrm{~m}$; it is an earth fill dam with storage capacity of 21 million cubic meters. The dam includes tunnels, bottom outlets, spillway and power station that have 4 units of Kaplan turbines with a capacity of $60 \mathrm{MW}$.(Adamo, Al-Ansari, et al. 2018; Al-Simawi, 2008; USACE, 2003). Refer to Figure 2, The Regulation Dam, Mosul Dam project. 


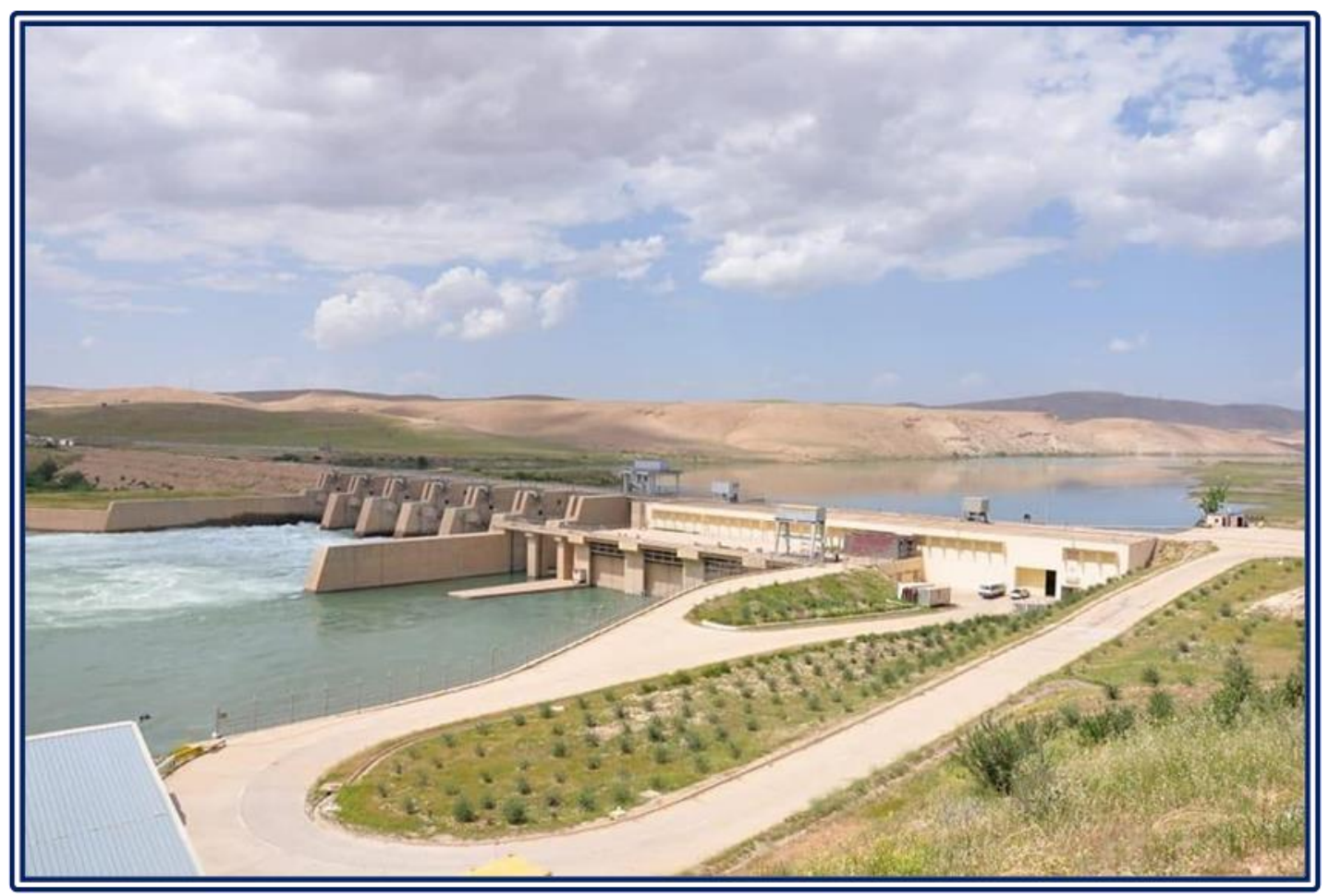

Figure 2: General view of the Regulation Dam, Mosul Dam project (MoWR n.d.).

After the opening of Mosul Dam in 1986, the leaks began to appear from the downstream of the dam body at rates higher than the expected rates. Measurement data for sensors in the dam were periodically discussed with Board of Experts. As a result, they decided that the dam administration to continue the grouting during the service life of the dam. Several sinkholes appeared in the dam site, the first sinkhole occurred in 1986, this was followed by a group of sinkholes that occurred from 1992 to 1998, these sinkholes lying nearly on an axis that parallel to main dam axis. There was also a spring observed in the river stream near the right bank. In February 2003, a large sinkhole occurred suddenly in the left bank near the curtain and the main dam. Also, another one occurred in 2005. A further sinkholes and cavities discovered at the bed of the lake itself and in the surrounding areas. As a result, Board of Experts had recommend to limit the storage at elevation of $319 \mathrm{~m}$ a.s.1. (Adamo, Al-Ansari, et al. 2018; Kelley et al. 2007; (Sissakian et al., 2018; Adamo, Sissakian, Al-Ansari, Knutsson, et al. 2018). Figure 3 shows the locations of sinkholes on the right bank downstream Mosul Dam. 


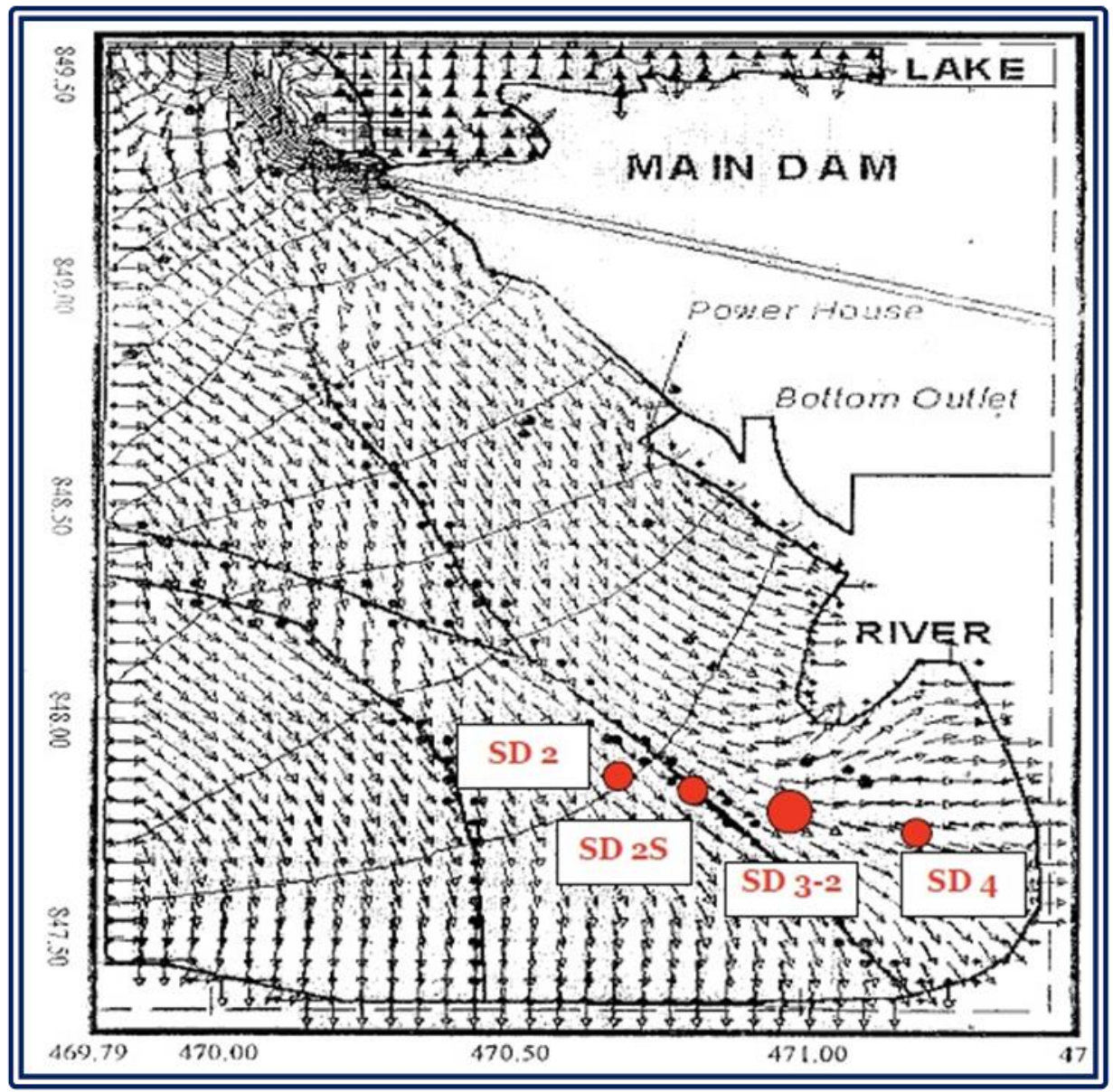

Figure 3: Locations of sinkholes on the right bank downstream Mosul Dam (Kelley et al. 2007).

The justification of the unexpected consequences in Mosul Dam foundations, which appeared after implementation were attributed to the lack of investigation and enough understanding of formations of gypsum beneath the dam. The estimated depth of gypsum formations was $100 \mathrm{~m}$, and then it is appeared that the depths of these formations are up to $300 \mathrm{~m}$ during the implementation. It was possible at the time to overcome this issue by constructing diaphragm wall in the foundation of the dam at the initial stages of implementation, this technique was available at the time, but requires an extension of the implementation period, which had no objections about by the Iraqi representatives.(Adamo, Al-Ansari, et al. 2018; Adamo, Sissakian, Al-Ansari, Knutsson, et al. 2018).

The Ministry of Water Resources after 2003 adopted the option of implementing a middle wall diaphragm, but another alternative adopted later, which is to continue the grouting of the base. After the chaos in 2014 and the occupation of Mosul Dam, the foundations issue spotlighted with an exceptional coverage by global media. This has been resulted the signing of a rehabilitation contract with the Italian company Trevi for the work of grouting, training, and maintenance of the dam. The 
company has continued to carry out the traditional grouting works with the supply of the dam project with modern sensors and rigs; they finalize the works on June 2019 (Al-Simawi, 2008; "Trevi Group Website" n.d.). A number of international organizations have also carried out simulations scenarios of the dam break, in addition to the studies prepared by the consultants who studied the dam at the beginning. Of these studies, it was found that the analysis of the default break of the worst scenario at the storage level $330 \mathrm{~m}$ a.s.l. will cause wave height of $25 \mathrm{~m}$, where the wave reaches the city of Mosul in 1 hour and 40 minutes, and reach the city of Baghdad in 3.5 days. The flood wave has effect on 6 million people, 2 million people with flooded areas to a depth of $2 \mathrm{~m}$ and 270 thousand people with flooded areas to depths of more than $10 \mathrm{~m}$. The most affected city is Mosul (Annunziato, Andredakis, and Probst, 2016). Figures 4 and 5 show the inundation of Mosul and Baghdad cities for the calculated Mosul Dam break scenarios when storage at elevation of $330 \mathrm{~m}$ a.s.l.

It is wise to mention the contribution by one of the researchers who made a bathymetric survey for Mosul Dam Reservoir in 2011. The results showed that the live storage of the reservoir had decreased from 8.16 to 7.597 billion cubic meters; the dead storage also had decreased from 2.95 to 2.37 billion cubic meters. The total storage became 9.967 billion cubic meters. The annual sediment income was 45.73 million cubic meters. The survey showed that the sediments were accumulated at the beginning of the reservoir, which is very natural. The interesting finding of this study is the discovery of cavities at the bed of the reservoir; in sizes comparatively, larger what had been founded downstream of the dam. Figure 6 shows the results of the bathymetric survey of the Mosul Dam reservoir and its comparison with the topography of the lake prior to its operation (Issa, 2015). 


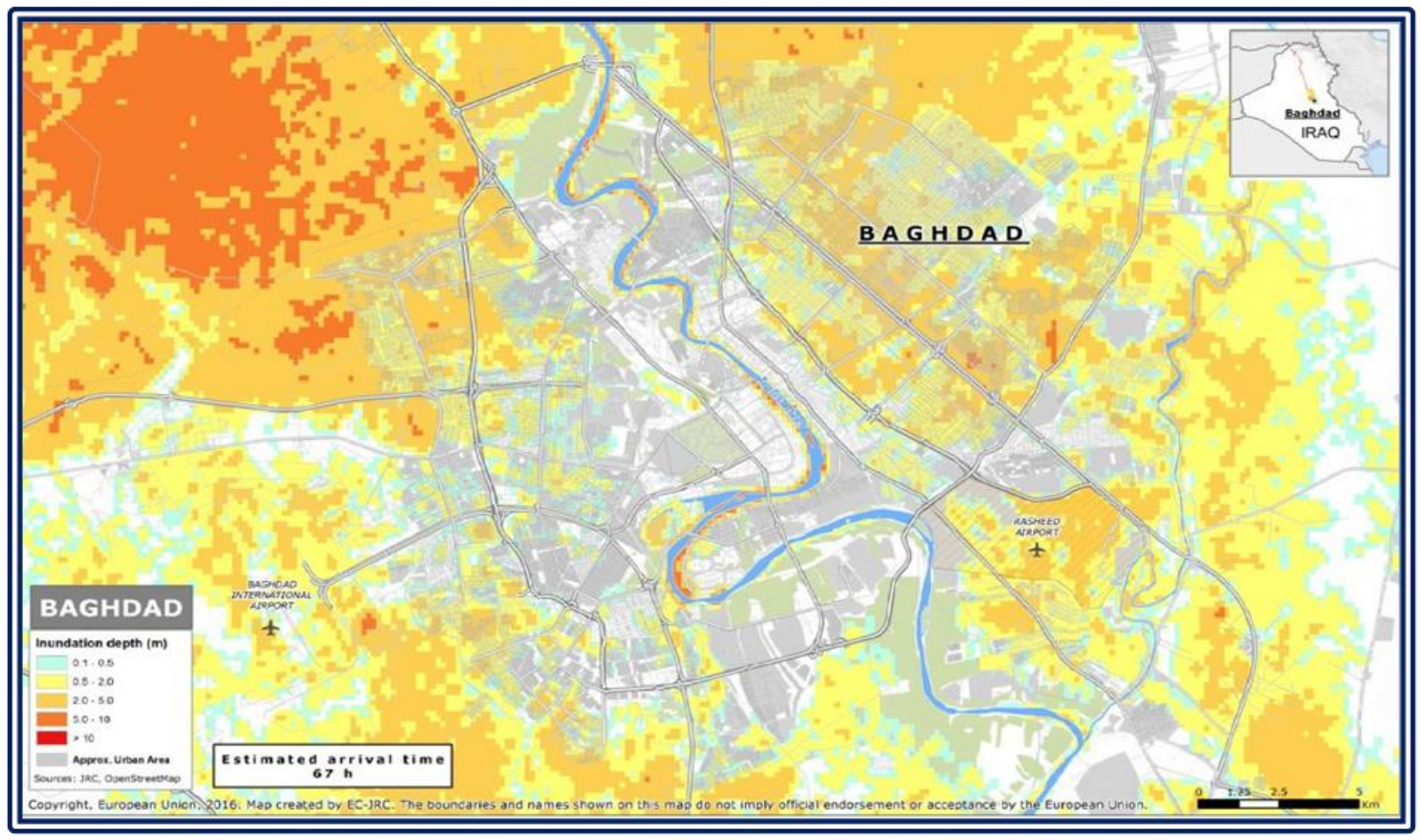

Figure 4: Inundation of Baghdad city for the calculated Mosul Dam break scenarios when storage at elevation of $330 \mathrm{~m}$ a.s.l. (Annunziato, Andredakis, and Probst, 2016). 


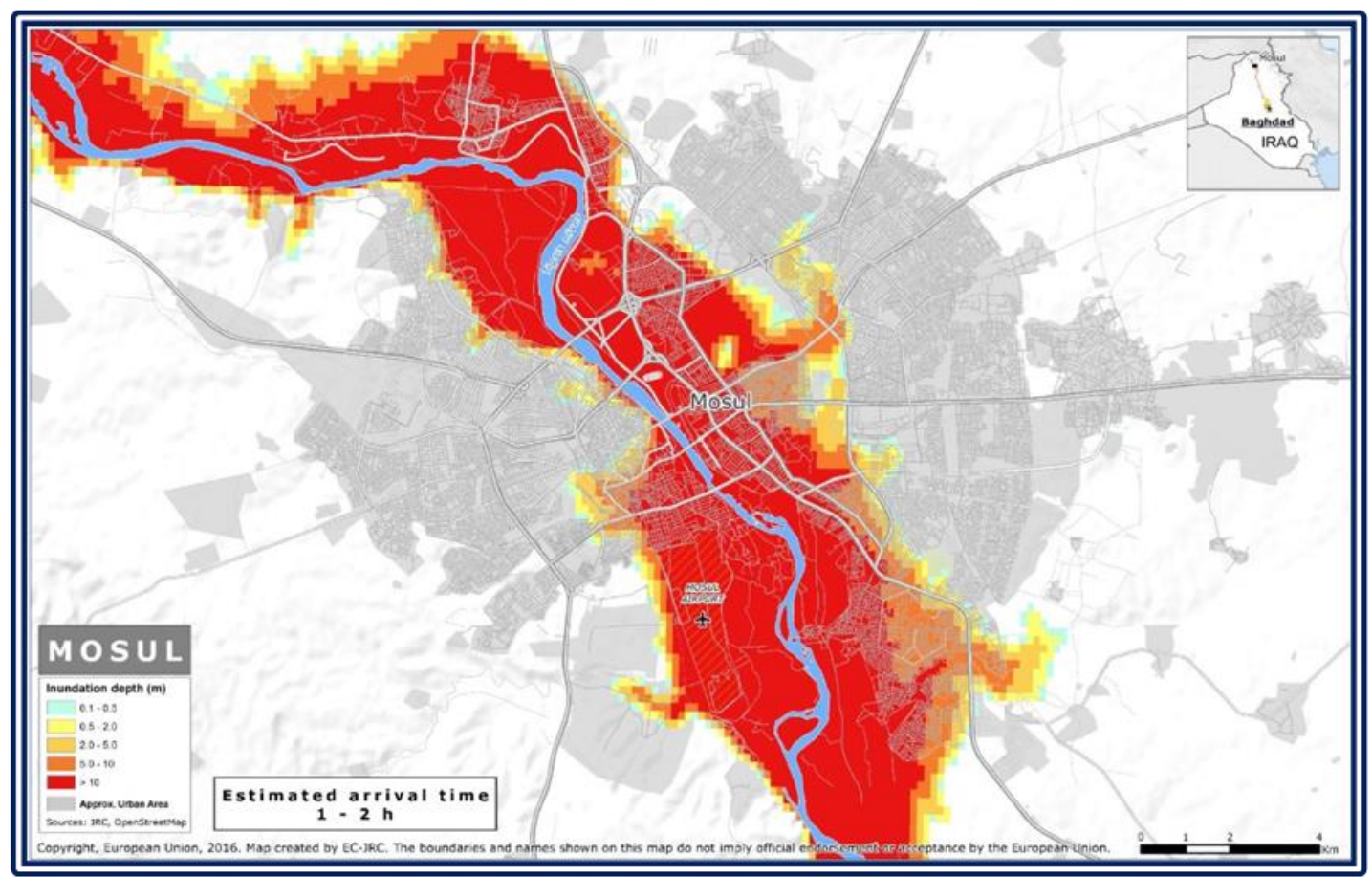

Figure 5: Inundation of Mosul city for the calculated Mosul Dam break scenarios when storage at elevation of $330 \mathrm{~m}$ a.s.l. (Annunziato, Andredakis, and Probst, 2016).

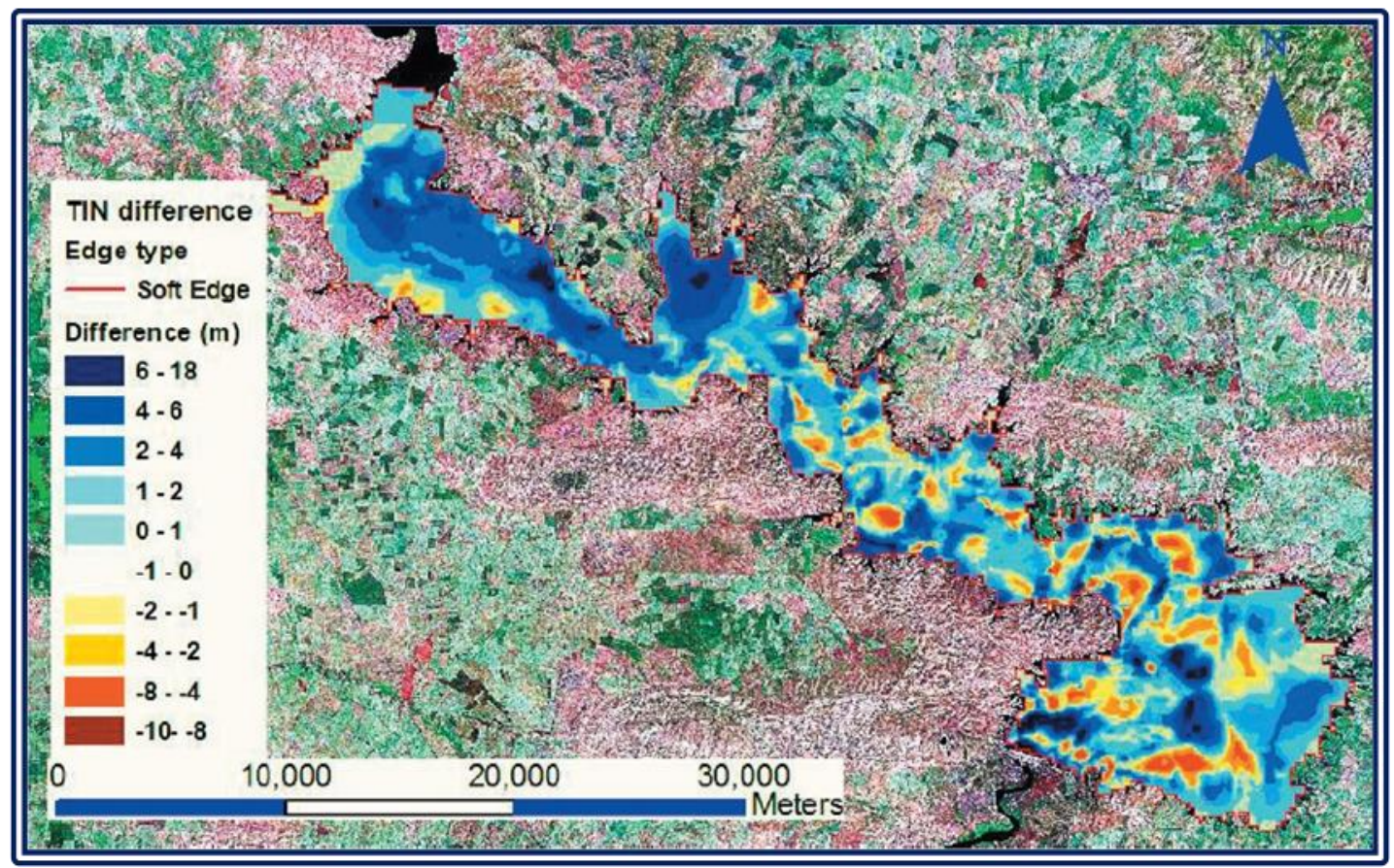

Figure 6: Bathymetric survey results of the Mosul Dam reservoir, and comparison with the topography of the lake prior to its operation (Issa, 2015). 


\subsection{Dokan Dam}

Dokan dam is the first dam that had been built in Iraq in the recent history; it is also the only concrete arched large dam in Iraq. The dam is located on Lesser Zab River in Dokan area and contributed with Dibis Barrage to feed Kirkuk strategic irrigation project. In the period before the era of Development Board, the Committee of Large Irrigation Projects had studied the proposed sites for a dam on Lesser Zab River. It was founded that among the selected sites, Dokan site is the most suitable because of the appropriate foundations and the existence of deep and narrow strait, which does not exceed $40 \mathrm{~m}$ width in drought season, and not exceeding $100 \mathrm{~m}$ width at height of $60 \mathrm{~m}$. When Development Board commenced, Benny and Partners Company were commissioned to study the dam project. The company submitted its report in 1952, and after evaluation by Board of Experts and doing the amendments in accordance with their recommendations, the company prepared the final designs and contractual document. Then, dam construction contract awarded to French company Dumez-Ballot, other contractors were participated in the construction and supplying dam equipment. The dam was completed in June 1959. The hydroelectric power plant works were subsequently appealed and started in 1975 with five Francis turbine units generates $80 \mathrm{MW}$ for each were they completed in 1979.(Al-Simawi, 2008; SMEC, 2006; Sousa, 1966).

The dam according to the final design is an arched concrete dam; the top level of the dam is $516.07 \mathrm{~m}$ a.sl. The tallest height of the dam body is $116 \mathrm{~m}$, the length of the dam at the top with side abutments is $345 \mathrm{~m}$ and the radius of curvature is 120 $\mathrm{m}$. The highest operating level of the Dokan reservoir is $511 \mathrm{~m}$ a.s.l. to impound storage of 6.8 billion cubic meters and a surface area of at that elevation equals to $270 \mathrm{~km}^{2}, 6.1$ billion cubic meters is the live storage. The minimum operational level is $469 \mathrm{~m}$ a.s.l. The dam has a Morning Glory spillway with a diameter of $40.26 \mathrm{~m}$ which is an emergency spillway works at elevation of $511 \mathrm{~m}$ a.s.l. and the maximum discharge is $1860 \mathrm{~m}^{3} / \mathrm{s}$, this spillway built in the left shoulder of the dam, and beside on the left another spillway, which is the basic spillway, it works at elevation $496.5 \mathrm{~m}$ a.s.l., this spillway has three openings with dimensions of $(10 \times 6.8) \mathrm{m}$. Both spillways divert the water through a tunnel buried in the left shoulder with a diameter of $11 \mathrm{~m}$. There are also two bottom outlets lined with steel, where the discharge for each is $110 \mathrm{~m}^{3} / \mathrm{s}$.(Al-Simawi, 2008; SMEC, 2006). Figure 7 shows a satellite view of Dokan Dam. 


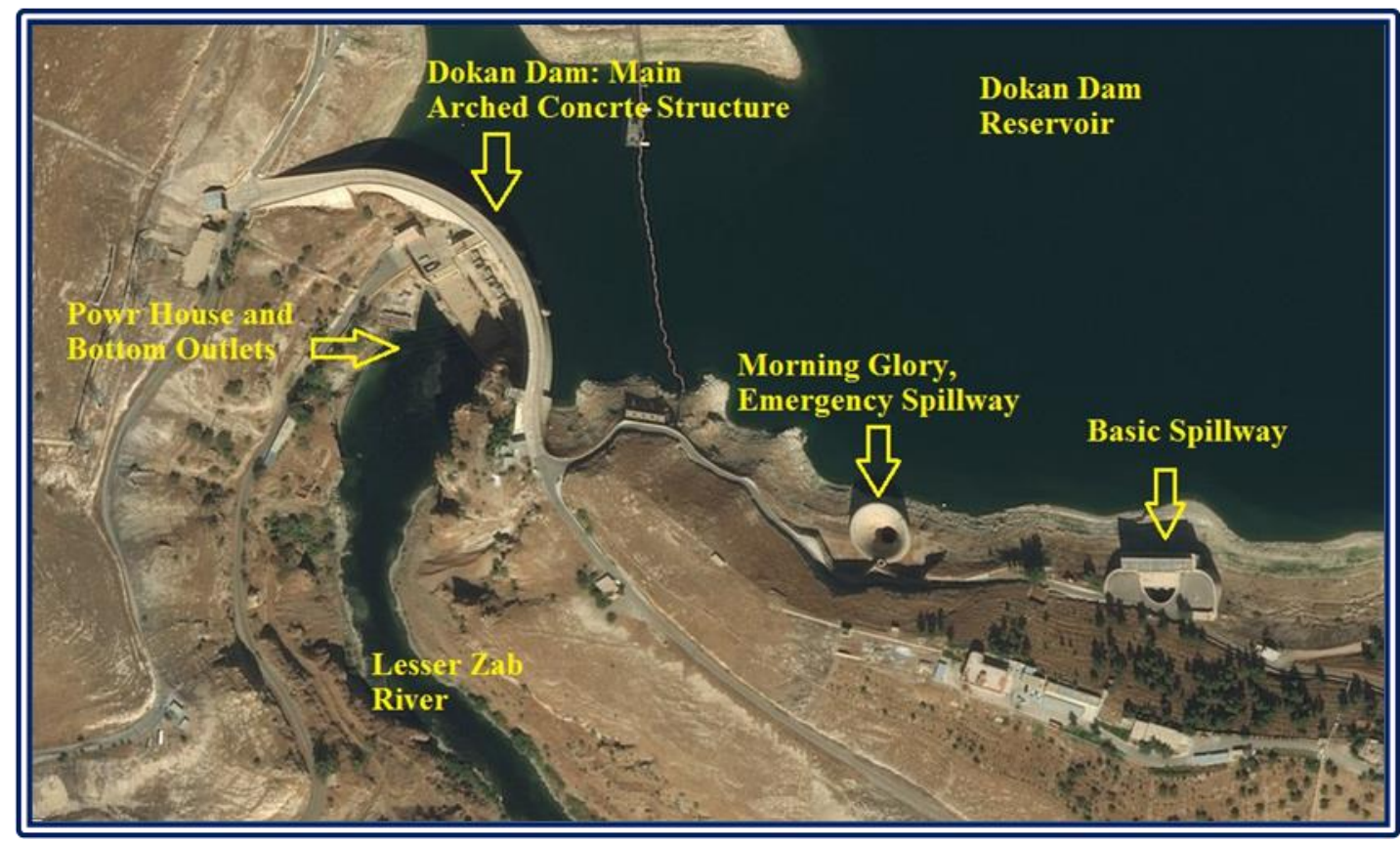

Figure 7: Shows a satellite view of Dokan Dam (Edited by Author; Esri n.d.).

In order to prevent the leaking on dam shoulders, two curtains of grouting had been implemented on both sides and up to depths of $300 \mathrm{~m}$, the length of the first curtain is $1350 \mathrm{~m}$ on the left side, was later extended to 220 meters, and the length of the curtain on the right side is $1000 \mathrm{~m}$.

Two inspection tunnels implemented on both sides, for the main tunnel on the left side it has a length of $450 \mathrm{~m}$. A collapse occurred in sections of the left tunnel, especially during flood seasons and high levels in the dam lake, this was later concrete lined and completed in 1980. There is also number of tunnels on the left side as well as the main tunnel. It was implemented within the body of the dam. These tunnels can be accessed through the elevator on the left of the dam body (AlSimawi, 2008).

The inspection tunnels in the sides of the dam suffer from of filtration, especially after the 1988 flood. Benny and Partners Consultants, were contracted to evaluate the dam in 1998, it was concluded that the source of the leak was the joints between the rock formations. The dam also needs the maintenance for gates of the outlets. Other leaking locations were observed in the structural joints of the Morning Glory spillway, where in 2000 an inspection engineers sent down through the spillway by crane, and the scenes from inside were filmed (SMEC, 2006). Figure 8 shows the leakage locations in morning glory spillway of Dokan Dam. 


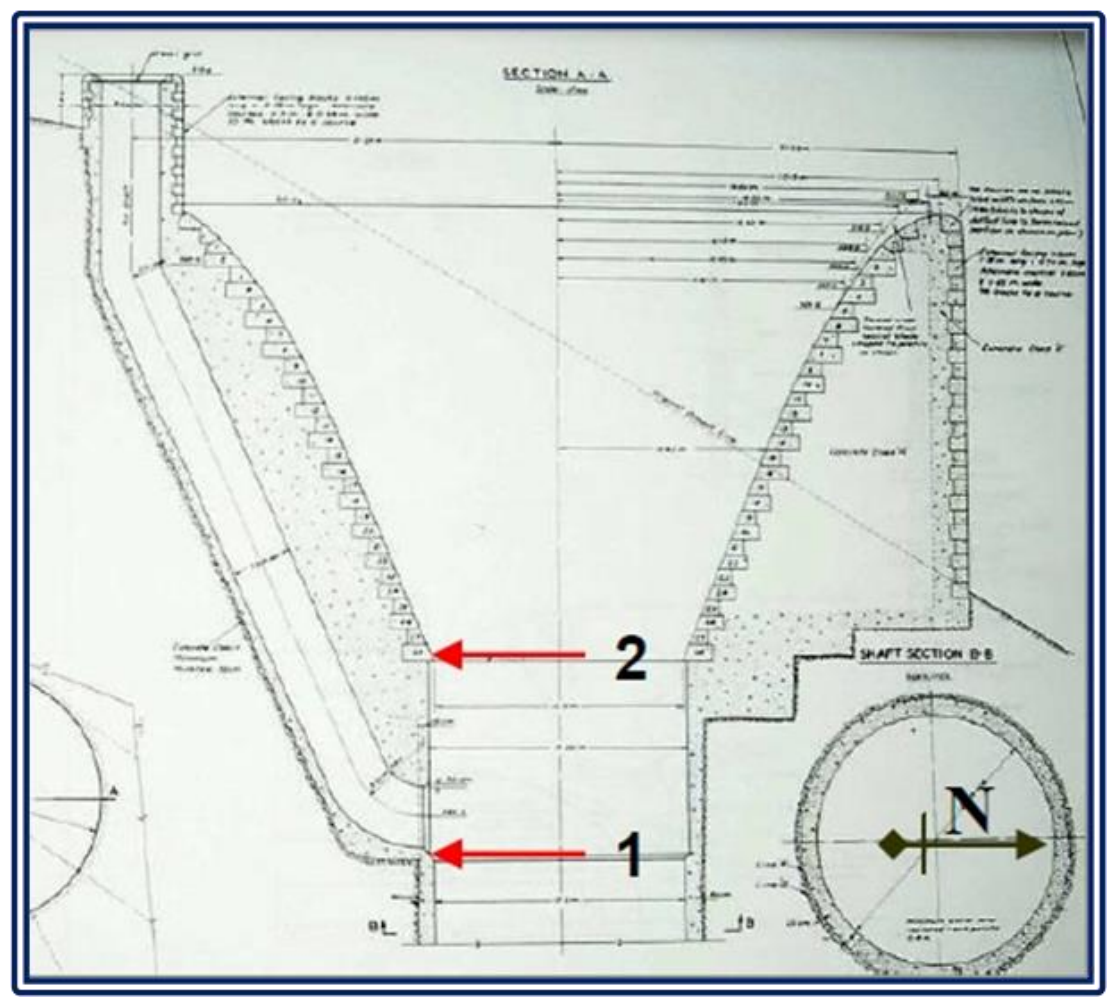

Figure 8: leakage locations in morning glory spillway of Dokan Dam (SMEC, 2006).

Regarding the bathymetric survey of Dokan Lake, a survey has been made in 2014 . The survey was carried out when the lake at storage elevation of $490 \mathrm{~m}$ a.s.l. However, results indicated that for the survey at this condition, the siltation volume was 209 million cubic meters, where the annual rate of sediments is 3.8 million cubic meters. Absolutely, the actual volume of sediments in the Lake is comparatively larger.(R. Hassan et al. 2019).

Despite of the above, it is unfortunate that the Ministry of Water Resources did not made any important treatments for this strategic dam, which is an important source of storage, knowing that there were enough funds achieved for the period of 2003 to 2014 and there were possibilities of contracting and training and the import of specialized materials and equipment easily. The action by the Ministry of Water Resources was to implement marginal and secondary effects projects such as construction of staff houses, forestation. While the essential works did not get the required efforts.

\subsection{Adhaim Dam}

Adhaim Dam is located on Adhaim River, which drains the water from the catchment that extends only inside Iraqi territories; the dam is located at the intersection of the Adhaim River with the Hemrin Hills. Building Adhaim Dam was presented since 1930s, later in the era of Development Board, Binnie and partners 
studied the project as part of its study for the region. The French company Sogreah contributed later to the preparation of a study about Adhaim Dam in 1989. Binne and partners submitted a study about the project again in 1989.

The project construction started in 1989 and stopped due to the blockade after 1990. Then in the mid of 1990s, the Ministry of Irrigation adopted the reinitiating of works in the dam site, Euphrates Design Center prepared the detailed maps and contractual documents, several other entities were participated in the project, including Faw Engineering Company, which had carried out the drilling of the power and irrigation tunnel (Resources, 2005; Ministry of Irrigation, 2001).

The dam project consists of the main dam body; a $3800 \mathrm{~m}$ long earth fill dam with clay core, maximum operational level is $131.5 \mathrm{~m}$ a.sl. with storage of 1.5 billion cubic meters, the tallest height of the dam body is $62 \mathrm{~m}$. Side slope of the dam body from the upstream side has a riprap of concrete blocks with size rages $(1-1.5) \mathrm{m}^{3}$, these blocks were based on a layer of graded gravel sub base (Al-Simawi, 2008). Figure 9 shows a general view of the dam body intake structure.

The dam has ungated spillway with a length of $562 \mathrm{~m}$ and a maximum discharge of $1150 \mathrm{~m}^{3} / \mathrm{s}$, at maximum flooding elevation of $143 \mathrm{~m}$ a.s.l. The dam also includes bottom outlets operating at a minimum level of $86 \mathrm{~m}$ a.s.l. which is the same level of river bet. In addition, there is a $50 \mathrm{~m}$ high intake structure that draws water to the tunnel excavated within the shoulders of the dam, this tunnel diameter is $4.5 \mathrm{~m}$ and it is $310 \mathrm{~m}$ long, and was lined with steel and concrete. The tunnel ends with two power outlets and one outlet for irrigation. It should be noted that the initial plan was the excavations of two tunnels in the adjacent hills, where it was reduced to one tunnel after re-evaluation of the design. The future power station includes two units with a capacity of $38 \mathrm{MW}$. The dam was opened in 1999 and the power plant is still incomplete. There are also needs for many devices and sensors required for safety and operation of dams, which was unavailable at the time of construction (AlSimawi, 2008; USACE, 2003). 


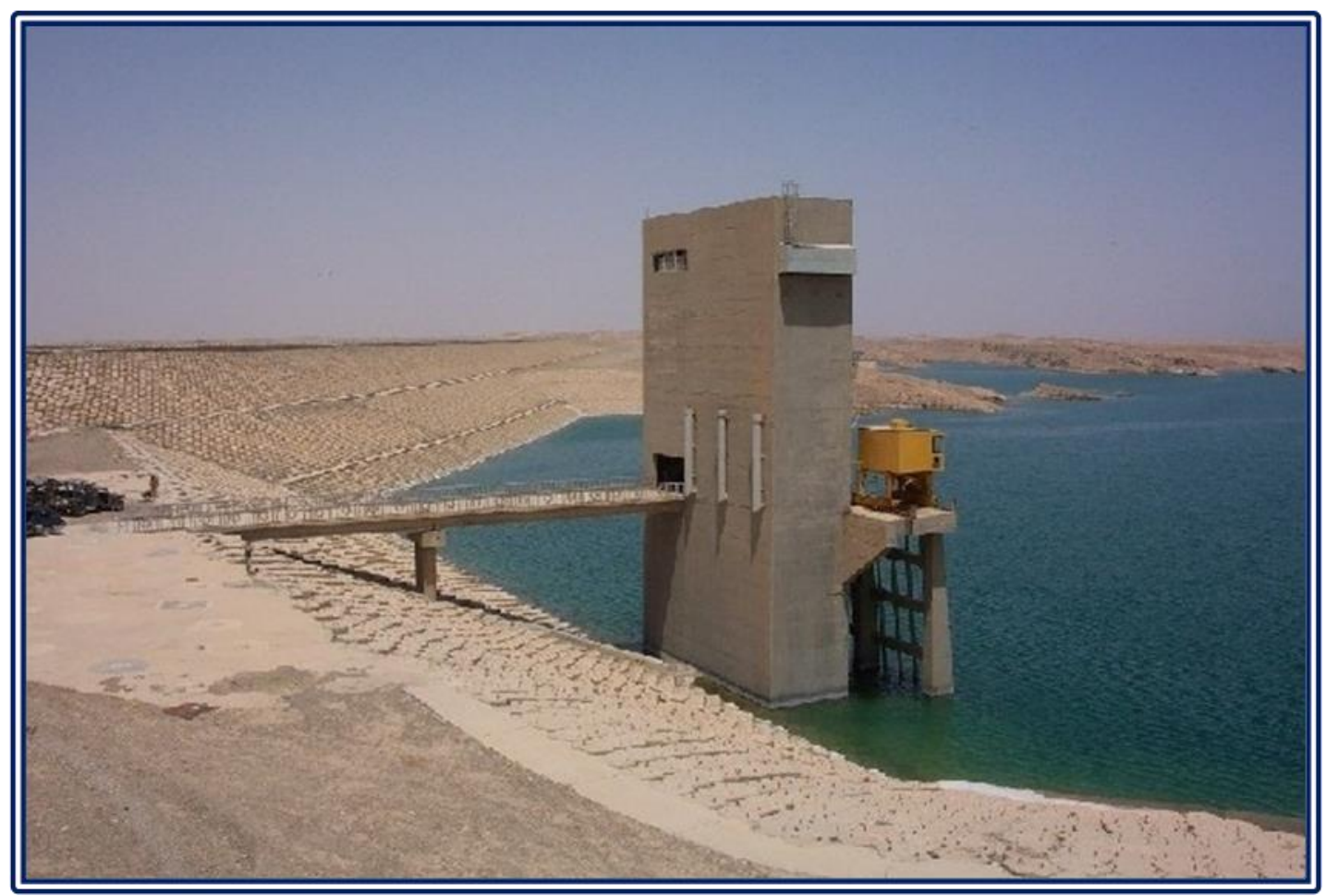

Figure 9: Adhaim Dam general view for the dam body intake structure (MoWR n.d.).

\subsection{Darbandikhan Dam}

Darbandikhan Dam is located on Diyala River at the Strait of Darbandikhan after the confluence of Tanjero and Sirwan tributaries, which form with some of small tributaries Diyala River. The idea of building a dam at the upper reach of Diyala River was put forward in the era of Coode Wilson and Heigh committees in 1930s and 1950s. After commencing of Development Board, Harza was commissioned to study the project and the geological investigations were entrusted to be carried out by Dr. C.L. Willis, where the alternatives was to build either concrete dam or an earth fill dam. The earth fill dam was chosen for technical and economic reasons. The implementation of the dam was initiated in 1956, where several companies took part in the project.

1. Darbandikhan Group of Companies is a consortium of companies including J.A. Jones Managing American Company, Inc. Texas Contractors Crop American Company, Inc. Beton Monierbau German Company, and C.H. Tompkins American Company to carry out the dam body and relevant work.

2. Cementation British company and Sondage Injection Forage French Company for drilling investigations.

3. Sainrapt \& Brice French company to implement sections of the conversion tunnel.

The dam was completed in 1961 (Al-Simawi, 2008; SMEC 2006; Sousa 1966).

Dam body has a clay core surrounded by a stone shell. The highest elevation of the 
dam is $128 \mathrm{~m}$ and the width at the top of the dam is $535 \mathrm{~m}$. The maximum operational level of the Darbandikhan dam is $485 \mathrm{~m}$ a.s.l., while the minimum operational level is $434 \mathrm{~m}$ a.s.l. with a design capacity of 3 billion cubic meter of which 2.5 billion is a live storage. The dam includes a spillway on the right side, the spillway has 3 curved gates with dimensions of $(15 \times 15) \mathrm{m}$, and spillway is divided into three sections that end with a flip bucket configuration. Spillway discharge is $5,700 \mathrm{~m}^{3} / \mathrm{s}$ at the maximum operational level, while the maximum discharge is $14,000 \mathrm{~m}^{3} / \mathrm{s}$ at maximum flood level of level $493.5 \mathrm{~m}$ a.s.l. (Al-Simawi, 2008; SMEC, 2006). Figure 10 shows a general view of Darbandikhan Dam from the upstream.

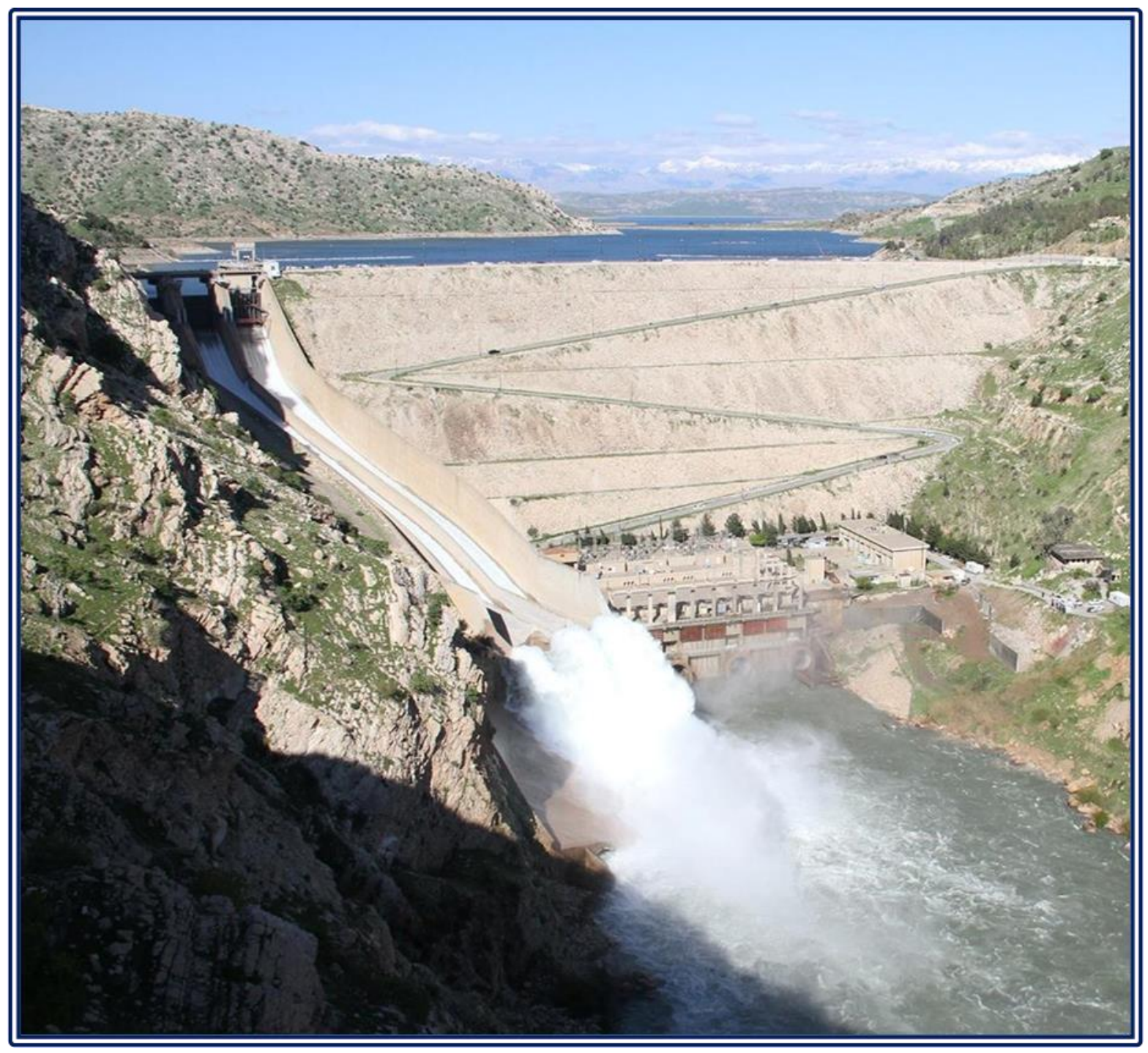

Figure 10: General view of Darbandikhan Dam from the upstream (MoWR n.d.). 
The project also includes two tunnels on the right side, the first one which were utilized for river diversion has a diameter of $6 \mathrm{~m}$ and a length of $775 \mathrm{~m}$, lined with reinforced concrete and ending with a section lined with steel with a diameter of $4.27 \mathrm{~m}$. Beside, another tunnel with a diameter of $9 \mathrm{~m}$ and a length of $662 \mathrm{~m}$, lined with reinforced concrete and the end part lined with steel for a length of $127 \mathrm{~m}$. From the first tunnel of $6 \mathrm{~m}$ diameter, a pipe with $4.28 \mathrm{~m}$ diameter had branched and other 2 similar pipes were branched for the $9 \mathrm{~m}$ diameter tunnel. These three pipes deliver maximum discharge of $446 \mathrm{~m}^{3} / \mathrm{s}$ for irrigation outlets and hydroelectric power station. The discharges to tunnels are controlled by the intake structure which extends with spillway approach inside the like for a distance of 120 $\mathrm{m}$. The intake structure has three openings with dimensions of $(4 \times 9) \mathrm{m}$ and $\mathrm{b}$ level of the bottom of the intake is $410.5 \mathrm{~m}$ a.s.1., two openings discharge to the tunnel with a diameter of $9 \mathrm{~m}$ and the third one to the tunnel with a diameter of $6 \mathrm{~m}$. The Intake is controlled by two steel gates have dimensions of $(4.75 \times 9.5) \mathrm{m}$. (AlSimawi, 2008; SMEC, 2006; Resources 2005).

At the beginning of the project, a mini hydropower station were installed to meet the operation requirements of the dam, this station has a capacity of $1600 \mathrm{KW}$. Later, the main three hydropower units with Francis Turbines, these were installed with total capacity of $240 \mathrm{MW}$, the main hydropower units works done by Polensky and Zöllner German Company which had implemented the works, while Mitsubishi Company installed turbines and generators, the hydropower station started generating in 1990 for the first time (SMEC, 2006; USACE 2003).

The dam also includes two grouting tunnels inside the body of the dam. The right tunnel starts beneath the spillway near the left wall, beginning at elevation of 415 $\mathrm{m}$ a.s.1., then continues with bottom of dam body up to elevation $366 \mathrm{~m}$ a.s.1. and for a length of $175 \mathrm{~m}$. The left tunnel extends from the surface and continues to a level of $373 \mathrm{~m}$ a.s.1. and for a length of $250 \mathrm{~m}$. 75 meters between the right and left tunnels is the space between their both ends without tunneling.

Darbandikhan Dam was exposed to several post-operational technical problems. The first is the existence of the dam within active seismicity area. As noted, the geologist Dr. C.L. Willis omitted the concrete dam choice as there is fault in the river bed. Binnie and Partners had analyzed the dam's seismic safety, and they infer in the 1987 report that the Darbandikhan Dam exists within a fold in the south-west direction, where the convergence of Arab tectonic plate and the Eurasian Plate. The Company had accounted maximum credible earthquake forecasted according data records and the seismic stability of the dam, it was founded that the dam is safe regarding seismic safety, noting that the dam site experience an earthquake during the initial stage of filling.

Unfortunately, the dam does not include sensors to monitor seismic activity, and monitoring devices in Sulaymaniyah had stopped since 1991.

On November 12, 2017, the area nearby the dam in the Iranian city Sarpol Zahab was stroked by 7.3-degree earthquake, the epicenter was $30 \mathrm{~km}$ from Darbandikhan Dam. The body of the dam was directly affected, cracks occurred in the body of the dam. The quake was followed by 53 aftershocks. Surveys were conducted by the 
Department of Surveying after the earthquake. There were cracks and settlements in some locations, especially at the top of the dam where the largest horizontal displacement was $27 \mathrm{~cm}$ in the center of the dam. On the left side, it reached $14 \mathrm{~cm}$ and on the right side $12 \mathrm{~cm}$. Dam body at the top moved toward the center of the dam and to the northeast and north-west direction. While, the vertical displacement was varied from $50 \mathrm{~cm}$ in the middle of the top and it was varied from 15 to $45 \mathrm{~cm}$ at the sides, as shown in Figure 11 (Al-Husseinawi et al., 2018).

The movement included the rocks on the right side mountain, some of which were fallen near the dam and the administration building, and the most dangerous of what had fallen on the spillway channel. These rocks, which are large in size, pose a future danger in the event of repeated tremors or slippage due to unstable positions. The most important threat is the possibility of damaging the gates or important elements of the dam. Figure 12 shows the effects of the earthquake in late 2017 in terms of cracks in the body the main dam as well as the fall of rocks on the channel of the spillway (MoWR n.d.; "Darbandikhan Official Account on Facebook" n.d.). Among essential needs of the currently is to re-evaluate the safety of the dam and the level of storage under the current circumstances, after exposure the dam site to the earthquake that exceeded the estimations. According to the consultant Binnie and Partners in 1987, the dam could resist an earthquake up to 6.5 degrees, but what happened in 2017 is and earthquake of 7.3 degree at a distance of $30 \mathrm{~km}$. A decision had been made to reduce the operational level, until the evaluation and recommendations were made by a technical authority. However, during the flood season of 2019 there was uncontrolled rise of the dam levels to the point where the spillway was operated. 


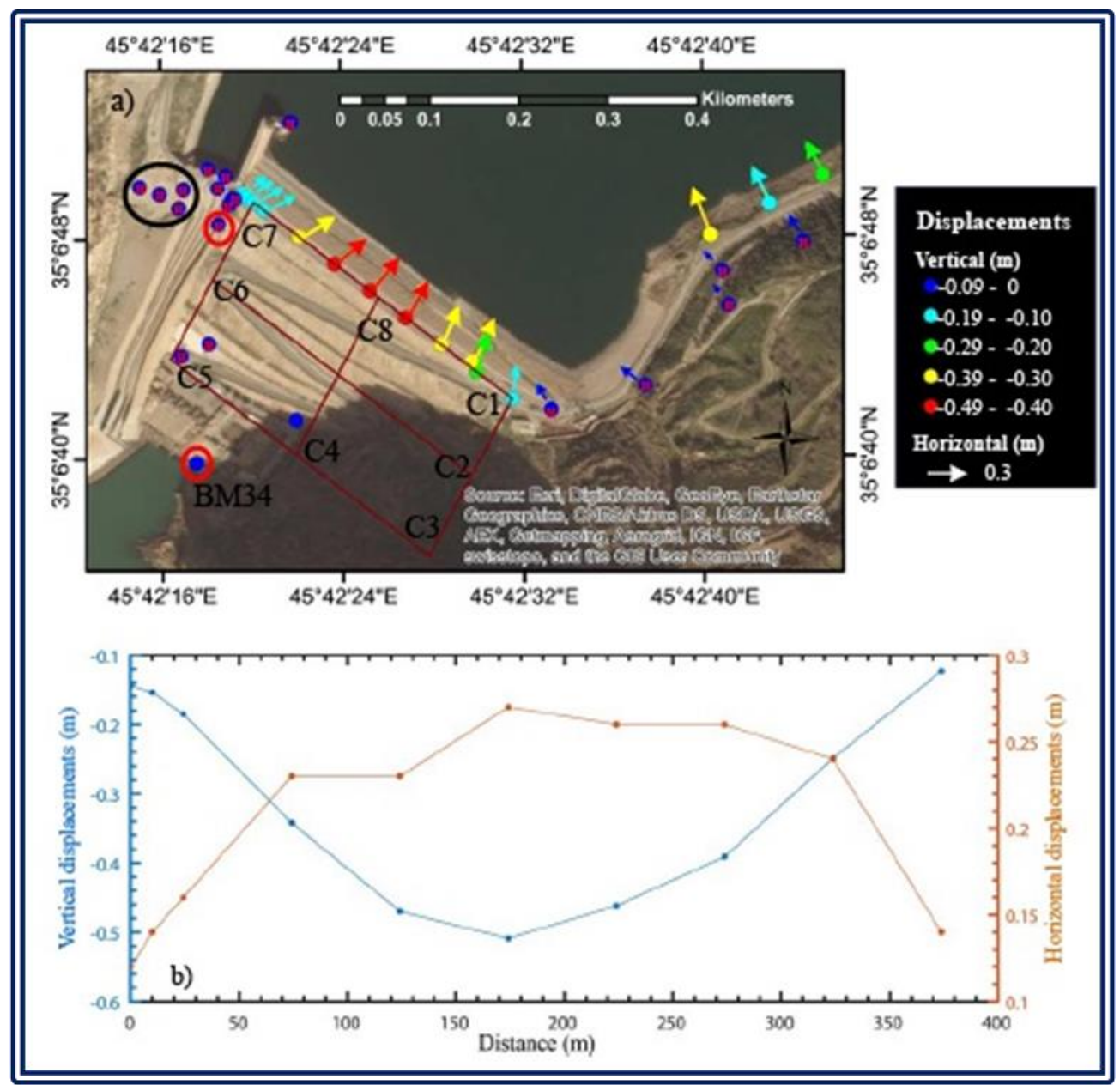

Figure 11: Horizontal and vertical displacement in Darbandikhan Dam body after the earthquake in November 2017 (Al-Husseinawi et al., 2018). 

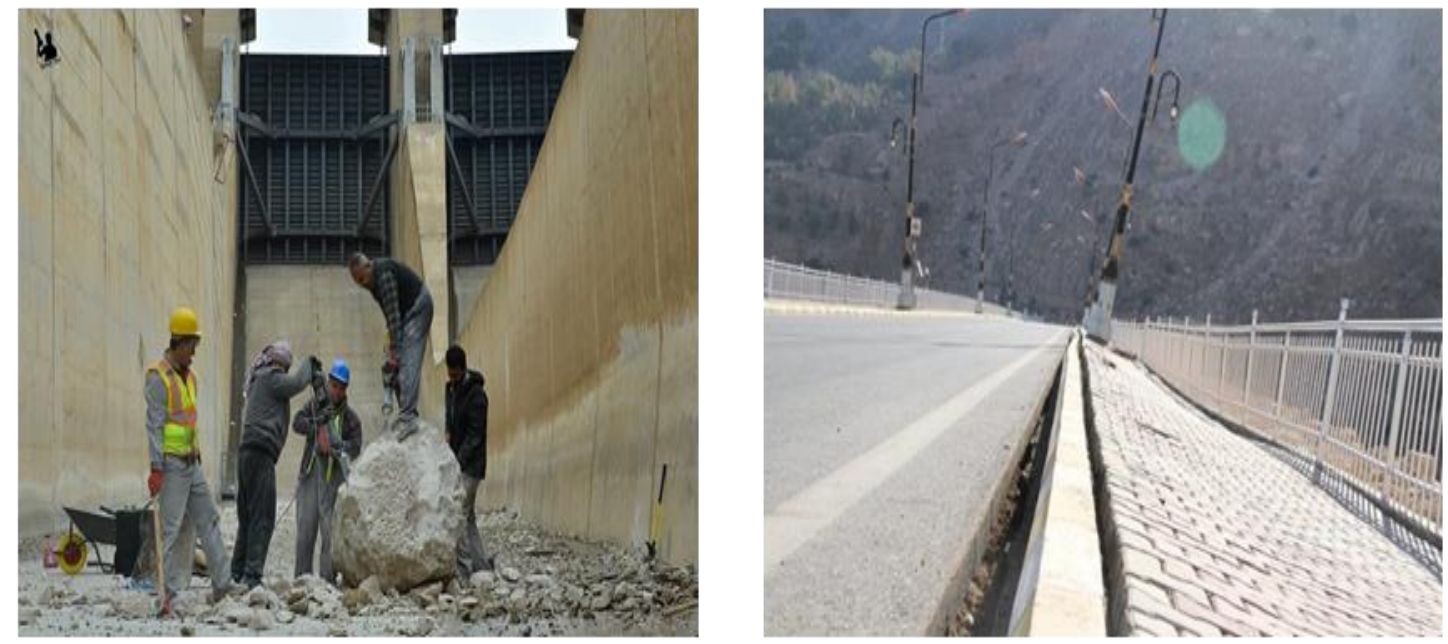

Figure 12: Aftermath of the earthquake in November 2017 at Darbandikhan

Dam; a) Right: cracks in the main dam body b) left: group workers are demolishing a stone that fallen in spillway chute from the adjacent mountain. ("Darbandikhan Official Account on Facebook"n.d.).

Land sliding in the right side of the lake is one of the most important issues in Darbandikhan Dam, this has been diagnosed during the construction of the dam, and measures were taken in terms of increasing the side slope of the dam body. The sliding occurred after five years of lake operation, where the sliding observed at 300 meters from the body of the dam on the right side, it was founded in 1967 that the affected section extends $350 \mathrm{~m}$ long and $200 \mathrm{~m}$ wide with a depression for about $1.5 \mathrm{~m}$. This sliding could make a mass of soil equivalent to 2 million cubic meters. The sliding was caused by precipitation occurred due to an intensive rainfall of 126 mm lasted seven days, and there was further rainfall between November 1969 and January 1970 (SMEC, 2006). Figure 13 shows the land sliding on the right of Darbandikhan Lake. 


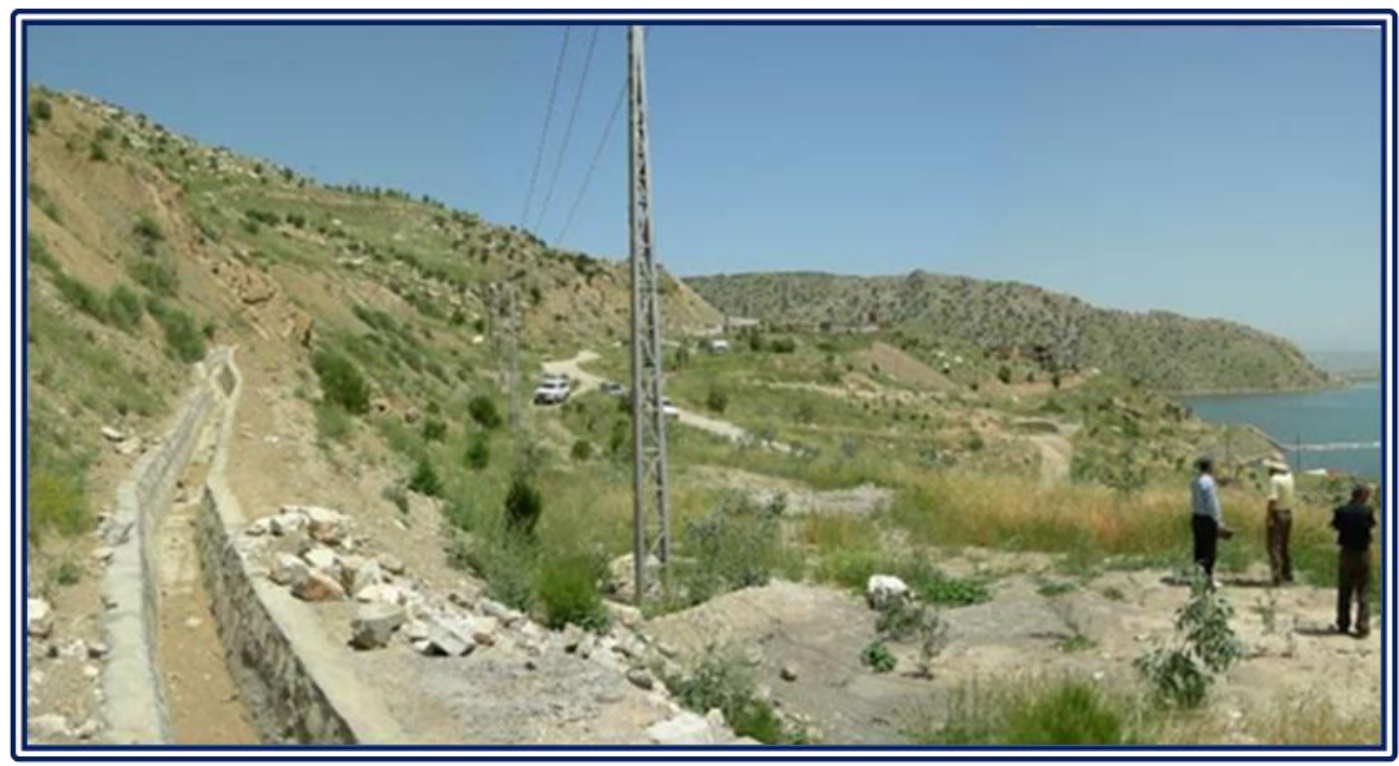

Figure 13: Land sliding on the right of Darbandikhan Lake (SMEC, 2006).

As a result, the French consultant Coyne \& Bellier and Iraqi company Dar Baghdad to had assessed the situation regarding the sliding, and after the study, they submitted the designs and recommendations for remedies in 1975. The main conclusions is that if a failure to stabilize the land sliding occurred, the movement of the soil mass towards the dam body may cause to:

1. The closure of the spillway and the tunnels inlets, which obstructs the flow and this cause a great risk in the flood season.

2. When the lake reaching its maximum level, the land sliding might generates water wave that overflow above the body of the main dam.

In order to address this risk, the consultant recommended the following:

1. Reduce the size of the sliding block and reach to elevation of $448 \mathrm{~m}$ a.s.l.

2. Carry out soil stabilization and drainage systems for the area under consideration.

3. Determination of $460 \mathrm{~m}$ a.s.1. as a minimum operating elevation for the dam lake.

4. Drilling 9 horizontal wells attached to pumping units to reduce moisture content in the affected area.

The implementation of the recommendations was initiated. Later, the dam was reevaluated by the same company and Binnie and Partners until 2006, where Coyne $\&$ Bellier had presented recommendations after a new assessment of the dam. The recommendations are summarized as follows:

1. Determination of $450 \mathrm{~m}$ a.s.l. as a minimum elevation for the operation of the lake, considering that the amount of reduction water levels is no more than 10 $\mathrm{cm} /$ day.

2. There is urgent need to implement surface drainages for the affected area. 
3. There is urgent need to clean and maintain horizontal wells.

4. Continuous monitoring and recording of pumping data from wells (SMEC, 2006).

Another sliding was observed on the left side of the lake near excavations dumping site, $400 \mathrm{~m}$ away from the dam axis. On-site investigations have been carried out and measures have been taken such as drilling horizontal wells. This slippage and other slips at the edges of the roads leading to the dam do not pose a danger to the safety of the dam (SMEC, 2006).

In 2008, fish poisoning occurred in the lake parts near the confluence of the Tanjero tributary. The analysis indicated that heavy metals were present in the water samples, which are pollutants from industrial and municipal waste (Ararat et al., 2008) It should also be noted that the circumstances of the fighting led to the lifting of the gates of the dam and emptying the lake in 1988, the gates were later re-installed (Ministry of Irrigation, 1988).

\subsection{Hemrin Dam}

Hemrin Dam, Darbandikhan Dam, and Diyala Barrage bring out an integrated hydraulic system to exploit Diyala River and the investment of agricultural land within the boundaries of the river. The idea of constructing a dam at the intersection of Diyala River with Hemrin Hills has been discussed since the 1930s and several places have been investigated. As the catchment area downstream Darbandikhan dam up to Hemrin Dam equals to $12,760 \mathrm{~km}^{2}$, this encouraged to think about the benefits of building the dam. In 1959, during the study of Sir M. MacDonald Consulting Company to Diyala River basin, a Reservoir of 2.27 billion cubic meters capacity was proposed at elevation of $105 \mathrm{~m}$ a.s.l.

In 1966, Energoprojekt, a Yugoslavian company was commissioned to study the dam project and conduct the necessary investigations. The company submitted its report in 1970. After the flood of Diyala River in 1974, the dam project came back and Energoprojekt entrusted to carry out additional investigations and final designs. The study and designs were presented in 1976. The same year, Hydrogradnja Company had commenced to carry out the works of the project, while Energoporjekt cooperating with Iraqi authorities had conducted the supervision of dam construction. The dam was completed in June 1981.

Hemrin Dam project consists of a main dam with a clay core, a height of $40 \mathrm{~m}$ and a length of 3,360 $\mathrm{m}$. The operational level of Hemrin Dam is $104 \mathrm{~m}$ a.s.l., the total storage size 2.06 billion cubic meters of which 2.04 billion is live storage. The dam has a gated spillway controlled by five radial gates with dimensions of $(10.6 \times 12.5)$ $\mathrm{m}$ for each gate; the maximum discharge of the spillway is $6,800 \mathrm{~m}^{3} / \mathrm{s}$ at the highest flood level which is $107.5 \mathrm{~m}$ a.s.l. Figure 14 shows the spillway gates of Hemrin Dam. The dam has also 4 irrigation outlets with total discharge of $250 \mathrm{~m}^{3} / \mathrm{s}$. There are also, hydroelectric plant with two Kaplan turbine units and total generation of $50 \mathrm{MW}$. Further, Inspection tunnels are inside the dam's body to lead to power house and irrigation tunnels (Al-Simawi, 2008; USACE 2003; Sousa 1966). 


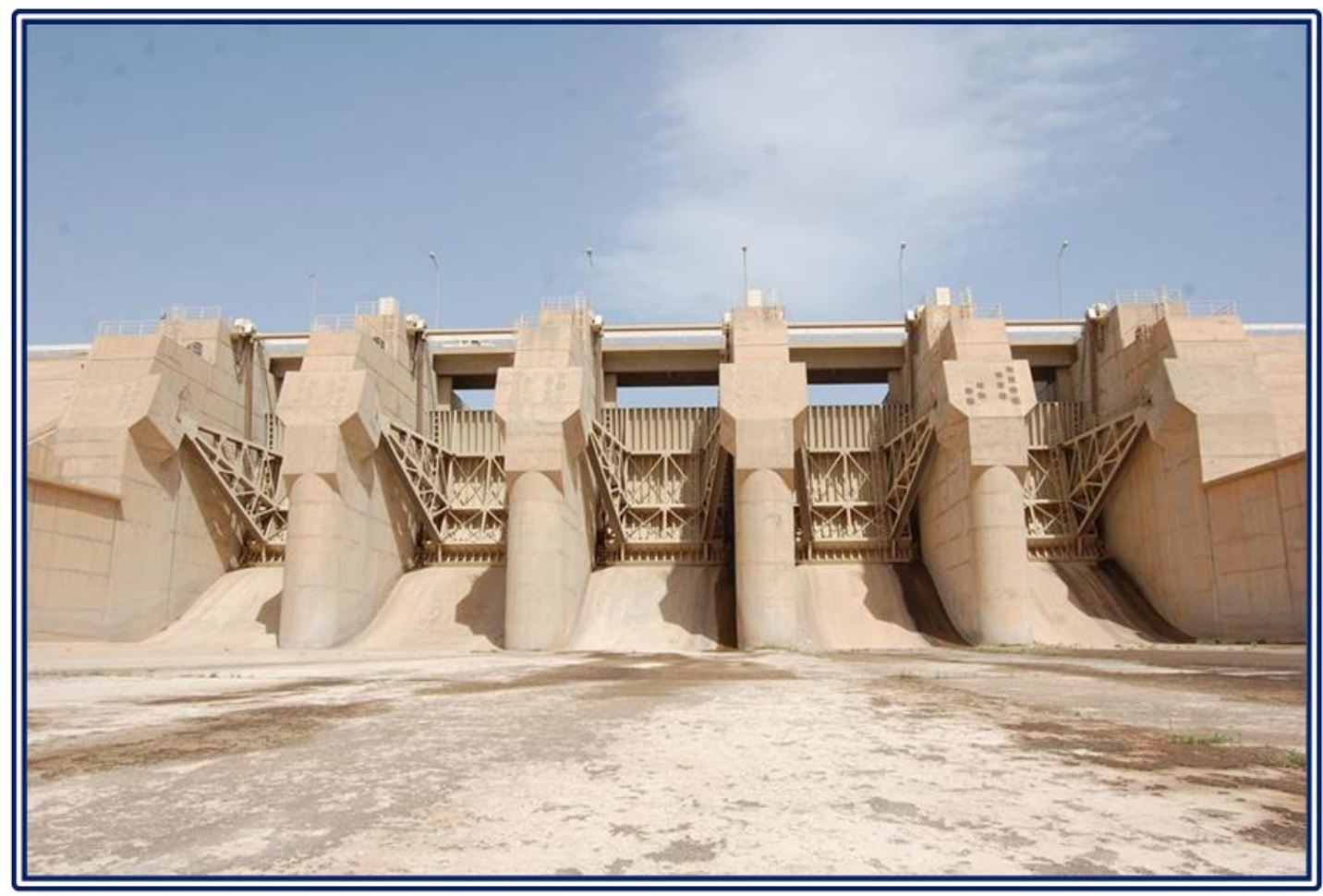

Figure 14: Spillway gates of Hemrin Dam, view from the downstream (MoWR n.d.).

In addition, there is also a fuse plug dam (Saddle Dam) which works as an emergency spillway with a discharge of $6,000 \mathrm{~m}^{3} / \mathrm{s}$, where the water diverted to Saladin flooding course that lead to Schweicha northern depression (Ministry of Irrigation, 1988). The project also included Sadiyah protection dykes to protect the city of Sadiyah, adjacent to the lake of the dam. It should be noted that KhanaqinBaqubah highway is passing inside the dam lake, the road has been built by constructing embankments in the lake, and there is a bridge in the middle allows the water flow between both sides of embankments.

\subsection{Haditha Dam}

Habbaniyah project implementation for some extent had delayed the interest in the construction of a storage dam on the Euphrates River. The first attempt to introduce this subject was submitted by Iraqi Engineer Vahi Sevian in 1945, he proposed in his report build a storage dam in the Upper Euphrates reach. The proposal included two sites: the reservoir of the first dam extends from city of Rawa up to Syrian border, and the second proposal for a dam in Khan Al-Baghdadi, where two sites had proposed, one of them causing the inundation Haditha city. The subject came back to the forefront in 1958, when the area was investigated for the construction of a dam north of Hit city by an Iraqi team, where four sites had proposed on 
Euphrates (Sousa, 1966).

The presence of the Soviet side in doing the irrigation plans and studies with the beginning of the republican era, hence; Technopromexport Company was entrusted to study a proposal of the dam on Upper Euphrates in Iraq. The preliminary suggestions included; first proposal is the building of two dams in Rawa and Haditha to avoid the flooding of the city of Anah and Rawa and, while second proposal is one dam in Haditha city, which is adopted.

Studies and evaluation had been continued by Technopromexport and Swiss consultants. Finally, the contract was signed for the study and design of Haditha Dam between the Iraqi Ministry of Irrigation and Technopromexport Company on 26/11/1947. The study and additional investigations were completed in 1979.

As a result of filling Haditha reservoir, water has to submerge Anah city and parts of the city of Rawa and many villages in the basin of the river, as well as many of the ruins in the area, where one of the most important is Minaret of Castle, which was dismantled and moved to a new location (Technopromexport, 1978; Saiid, 1978). Figure 15 shows the Minaret of Castle that had been moved to a new place. Also, the project included the construction of the new Ana city and the construction of new villages and farms for citizens who have to leave their homes. (Technopromexport, 1978)

Dam works started since 1977 and completed in 1988, the initial works was began before the completion of studies, such as roads, camp, and various infrastructures of the dam site. Detailed design and implementation of the hydroelectric plant were entrusted to the Yugoslav company Energoprojekt. While Technopromexport carried out the other designs and general supervision of the project in cooperation with Directorate General of Dams at the time. The use of Mealy Dolomite as a core material for the earth fill body of the dam was the first time used in the dam in the world, also, it's the first time to use asphaltic diaphragm with this materials for. This exceptional design required more time for the necessary tests and research (Adamo, Sissakian, Al-Ansari, Elagely, et al., 2018). 


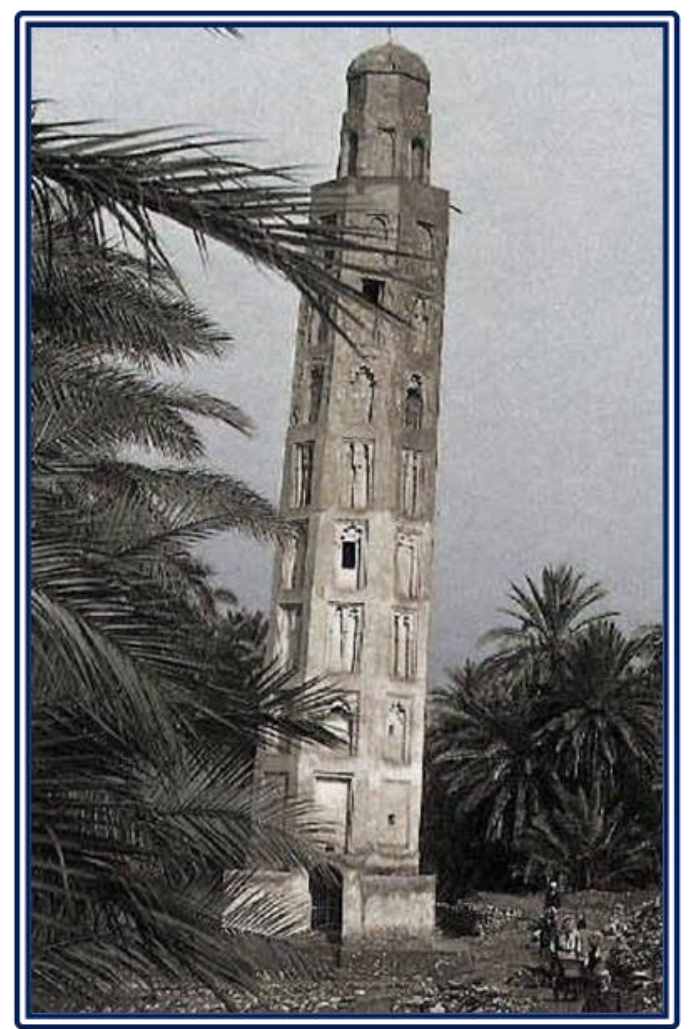

Figure 15: Minaret of Castle before moving due to inundation of Anah city (Saiid, 1978).

Haditha Dam project consists of the main dam with mealy dolomite core and asphaltic diaphragm in the middle, the core is shelled with mixed gravel, and the dam body lined with concrete from the upstream and it is lined with concrete blocks from the downstream as a riprap. The dam body composed of three parts, two earth fill parts and the middle concrete part. The right part has length of 3,230 m, the left part length is $495 \mathrm{~m}$, and the concrete part which constructed in the river section has a length of $580 \mathrm{~m}$ which includes most of the concrete parts such as spillway, power house, and bottom outlets. The tallest height of the dam body is $57 \mathrm{~m}$ and its total length is $8,950 \mathrm{~m}$. The top of the dam elevation is $154 \mathrm{~m}$ a.s.l. The lake of the dam has a capacity of 8.2billion cubic meters at the maximum operational level of 147 $\mathrm{m}$ a.sl., the live storage is 5.8 billion cubic meter. Dam includes also the spillway which controlled by radial gates, the spillway consists of 6 openings of $16 \mathrm{~m}$ width, the maximum discharge of the spillway is $11,000 \mathrm{~m}^{3} / \mathrm{s}$ at elevation of $150.4 \mathrm{~m}$ a.sl., which is the maximum flood elevation. There are two bottom outlets with dimensions of $(4 \times 6) \mathrm{m}$ and discharge of $500 \mathrm{~m}^{3} / \mathrm{s}$, at the minimum operating level of 112 m a.s.l.(Al-Simawi, 2008; Technopromexport, 1978; Adamo, Sissakian, AlAnsari, Elagely, et al., 2018). Figure 16 shows the middle section of Haditha Dam. 


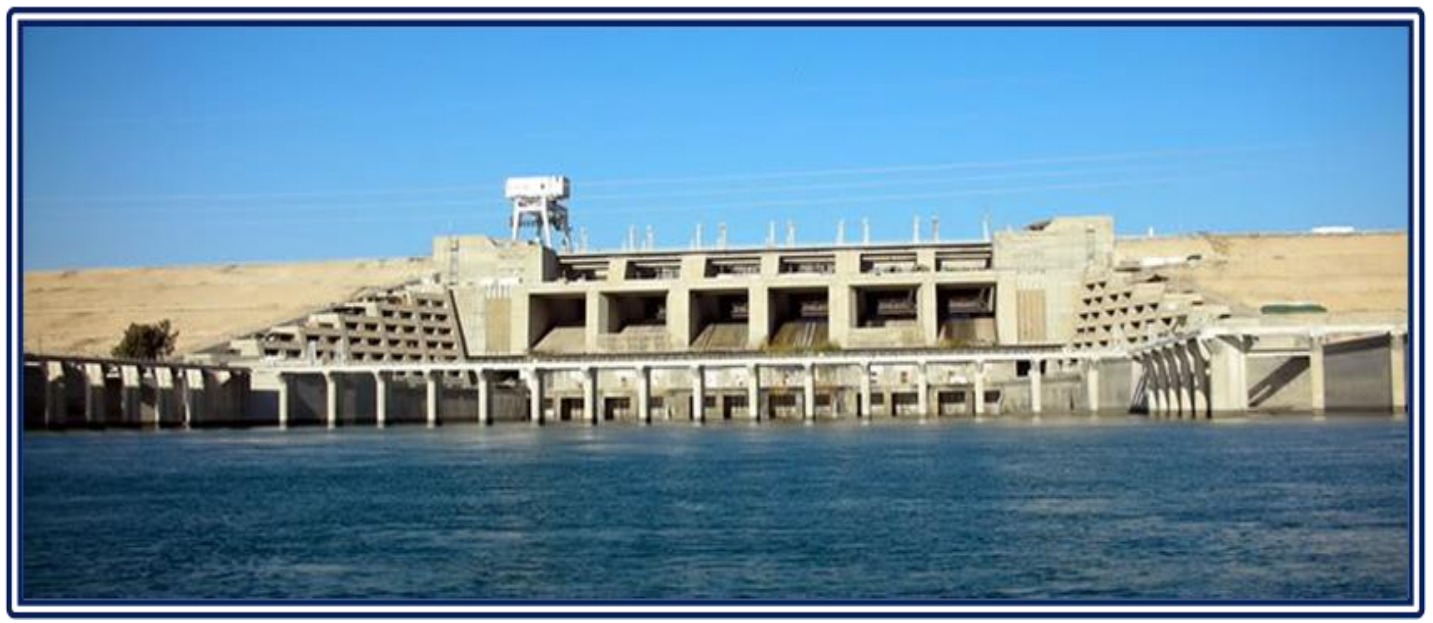

Figure 16: Concrete Section of Haditha Dam, view from the downstream (MoWR n.d.).

Among the most important Haditha Dam installations is the hydroelectric plant, which includes 6 Kaplan turbine units with a capacity of 570 MW and a total discharge of $2.034 \mathrm{~m}^{3} / \mathrm{s}$ (Al-Simawi, 2008; Li et al., 2018).

The dam includes two grouting tunnels for both sides. Regarding the grouting, a curtain grouting was implemented with two lines and depths up to $80 \mathrm{~m}$. Also, blanket grouting was carried out under the foundations of the dam and at depth of $10 \mathrm{~m}$ at the bed of the river, and $5 \mathrm{~m}$ deep under the dam. The seepage control system in the Haditha Dam is the Relief Wells, which are distributed in the downstream of the dam body. The dam is also provided with piezometers and sensors. (Adamo, Sissakian, Al-Ansari, Knutsson, et al. 2018).

In general, Haditha dam does not suffer from major problems, but needs for comprehensive technical evaluation after more than 30 years of operation and requires the maintenance and rehabilitation for piezometers.

In comparison with Mosul Dam, Haditha dam has successful designs and measures in term of foundations treatment, especially the overcoming of karstification problem. Where the measures taken in the Haditha Dam have succeeded more than what is achieved in Mosul Dam, and for the purpose of comparison between the two dams, the following points are presented:

1. The two dams are located on the Arabian plate, where the Mosul Dam is located within Fatha geological formation, while Haditha Dam is located within the Euphrates geological formation.

2. Both of the dams were built on sedimentary rocks where the karst activity is scattering beneath. Karst layer sequencing extends in Mosul dam site for $300 \mathrm{~m}$, while it extends in Haditha Dam for $50 \mathrm{~m}$.

3. Mosul Dam foundations have gypsum layers, while Haditha Dam foundations have limes layers, where the former is more soluble.

4. There was no timetable for conducting geological investigations in Haditha Dam, the work were done with all necessary to make the required tests or 
investigations for developments, and it did not happen in Mosul Dam Project (Adamo, Al-Ansari, et al. 2018; Adamo, Sissakian, Al-Ansari, Knutsson, et al. 2018).

\section{Small and Medium Storage Dams}

Dozens of storage dams of medium and small capacity, and water harvesting dams are scattered throughout Iraq. These dams can be found in three main areas:

1. Mountainous and undulating region of Duhok, Erbil, Kirkuk and Sulaymaniyah governorates.

2. Eastern valleys area in Diyala, Wasit and Maysan governorates.

3. Western Desert area in Anbar, Najaf and Muthana governorates.

\subsection{Small and Medium Storage Dams in the Northern Area}

In Mountainous and Undulating areas, there are many dams, most of which were built after 2003. Data about number and existence of small dams in this territory is not precise; there are many dams, which are not registered by Iraqi Ministry of Water Resources. However, the most important known dams are:

1. Duhok Dam: is located Duhok valley, which is and earth fill dam with clay core. In 1978, the site of the dam was studied and designed by the Bulgarian company Akrocomplect. Implementation was started and completed in 1988. The dam is 60 meters high and length at the top is $613 \mathrm{~m}$. The dam has a storage capacity of 52 million cubic meters. The dam includes morning glory spillway with a discharge of $81 \mathrm{~m}^{3} / \mathrm{s}$. There is also an irrigation outlet, a tunnel 2,035 $\mathrm{m}$ long and $2 \mathrm{~m}$ in diameter leading to the Duhok irrigation project.

2. Harawa dam: The dam is located on the Harawa Valley in Sulaymaniyah governorate. The dam study was prepared by FAO in 2002 . It is $22.5 \mathrm{~m}$ high and $115 \mathrm{~m}$ long, with storage capacity of 0.764 million cubic meters. It was completed in 2007.

3. Azmar Valley Dams: seven weirs on Azmar Valley in Sulaymaniyah governorate. It was completed in 2006.

4. Khasa Chai Dam: it is located on Khasa Chai Valley in Kirkuk governorate. It was made from earth fills with clay core. The height of the dam is $58 \mathrm{~m}$. It is 2,360 m long. The storage capacity of The Dam Lake is 46.36 million cubic meters. Implementation was started in 2009 and completed in 2014.

5. Qashkan Dam: it is located on Qashkan Valley in Duhok governorate. The Dam designs were prepared by Center of Studies and Designs, Iraqi ministry of water resources, and the Implementation was carried out by General Commission of Dams and Reservoirs. The dam is $270 \mathrm{~m}$ long and the size of the dam lake is 1 million cubic meters. The dam includes a $6 \mathrm{~m}^{3} / \mathrm{s}$ discharge outlet.

6. Shirin Dam: it is located on Shirin Valley in Lailan district. It is a 426 meter long earth fill dam. Storage capacity of 1.325 million cubic meters. It has an outlet of discharge $6.23 \mathrm{~m}^{3} / \mathrm{s}$. As well as a 50 -meter-long spillway, with discharge capacity $203 \mathrm{~m}^{3} / \mathrm{s}$. The dam was completed in 2008 . 
7. Wand Dam: the dam is located on Wand River in Diyala governorate. The study on the dam was first submitted by the Bulgarian company Akrokompelket in 1979. It is 1342-meter-long earth fill dam, and $24 \mathrm{~m}$ high. It includes non-gated spillway of $35 \mathrm{~m}$ long and $140 \mathrm{~m}^{3} / \mathrm{s}$ discharge. The storage capacity of the lake is 37.82 million cubic meters. The dam was completed in 2013.

8. Belkana Dam: it is located on Belkana Valley in Kirkuk governorate. It is an earth fill dam with clay core. The dam is $277 \mathrm{~m}$ long, and the operational storage of the dam is 0.89 million cubic meters. The dam has an opening of discharge $6.46 \mathrm{~m}^{3} / \mathrm{s}$. As well as, there is un-gated spillway of $35 \mathrm{~m}$ long and discharge $207.9 \mathrm{~m}^{3} / \mathrm{s}$.

9. Shewasur Dam: the dam is located in Shwan district in Kirkuk governorate. It is 26 meters high and 333 meters long. Storage capacity is 4.45 million cubic meters. The dam was completed in 2016.

10. Bahiri Dam: the dam is located in Zawita area in Duhok governorate. It is one of the dams implemented by Duhok Irrigation Directorate and funded by a U.S. agency. The dam has a height of $18 \mathrm{~m}$ and storage capacity of 0.38 million cubic meters.

11. Chaq-Chaq Dam: it is located in Sulaymaniyah governorate. The dam designs were completed by the Bulgarian company Akrokomplekt and implemented with funding from the international organizations prior to 2003. The dam collapsed due to a high wave in 2005 .

12. Chali Dam: It is located on the Samaqully Valley east of Erbil. The dam reservoir has a capacity of 8.6 million cubic meters. It was opened in 2018.

13. Durger Ajam Dam: it is located in Duhok governorate within the valleys of the Khabur Basin. The dam is $15 \mathrm{~m}$ high and has a storage capacity of 0.15 million cubic meters.

14. Kasnazan Dam: the dam is located in Erbil governorate within the valleys of the Great Zab Basin. It is $10 \mathrm{~m}$ high and has a storage capacity of 0.32 million cubic meters.

15. Hamamuk Dam: it is located in the Koya area. The dam is $24 \mathrm{~m}$ high and the storage capacity is 0.35 million cubic meters.

16. Hassan Kanoush Dam: it is located in the Chamchamal area. The dam is $15 \mathrm{~m}$ high and storage capacity of 0.35 million cubic meters.

17. Bawa-Shaswar Dam: it is located in Koya area. The dam is $23 \mathrm{~m}$ high and storage capacity of 4.4 million cubic meters (Resources, 2005; Al-Simawi, 2008; USACE, 2003; Al-Simawi, 2010). 


\subsection{Small and Medium Storage Dams in Eastern Valleys}

Eastern valleys are promising source of water storage and harvesting. The main problem in the region is the high rate of sediment load; hence, many dams were failed. More measures and fine tuning in selection of the dam site and erosion protection are needed. Other alternatives could be proposed as the underground reservoir, this requires a detailed investigations and data. The dams in this region are:

1. Qazaniyah Dame: it is located on the Harran Valley in Diyala governorate. The dam was studied by Euphrates Center and then studied by Tigris Center in 2004; both are directorate of Iraqi ministry of water resources. The dam is a 6.5 -meterhigh weir dam with lake of 0.9 million cubic meters capacity. It was completed in 2007. Also, the dam considered one of the dams that suffering from sedimentation.

2. Mandalay Dam: it is located on the Harran Valley in Diyala governorate. Studies were started in 2002 and completed in 2004. It is earth fill dam with clay core, $14 \mathrm{~m}$ high and $1,316 \mathrm{~m}$ long. The capacity of the dam lake is 3.63 million cubic meters. The dam has a 250 -metre long spillway and discharge of $1,725 \mathrm{~m}^{3} / \mathrm{s}$. Dam reservoir is almost full with sediments. Figure 17 shows a general view of Mandaly Dam Reservoir filled with sediments.

3. Shihabi Dam: it is located on Shihabi Valley in Wasit governorate. The dam was implemented by Al-Rafidain Company, where the dam is a $275 \mathrm{~m}$ long and $9 \mathrm{~m}$ high. It includes a 160 meter long spillway. The capacity of the dam lake is 0.8 million cubic meters. Like other dams in the eastern valleys, the dam is filled with sediments.

4. Dwerej Dam: the dam is located on the Dwerej Valley in Maysan governorate. The dam is a concrete weir with other retention dam in the form of Gabions. The dam was carried out by Al-Rafidain Company and is $510 \mathrm{~m}$ long and $9.5 \mathrm{~m}$ high. The capacity of the dam lake is 1.87 million cubic meters. It was completed in 2015.

5. Badra Dam: it is located on Badra Valley in Wasit governorate. It is a concrete weir of $3 \mathrm{~m}$ high and 800 meters long (Al-Simawi, 2008; Saeed, 2018). 


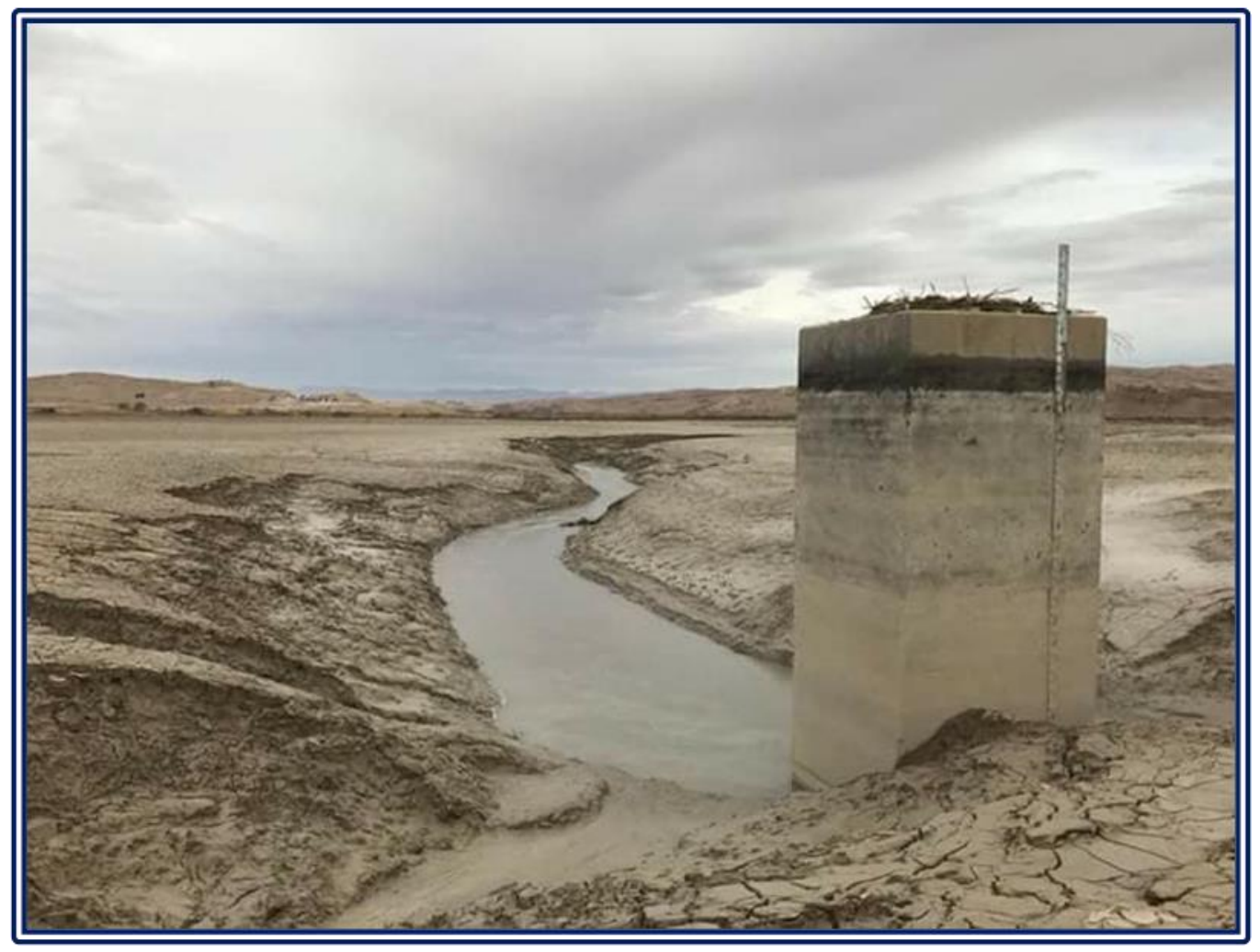

Figure 17: General view of Mandaly Dam Reservoir filled with sediments. (MoWR n.d.)

\subsection{Small and Medium Storage Dams in the Western Desert}

Several dams were built during 1970s and 1980s in the western desert, the area is wide and promising for water harvesting and creating a new spot for living and agriculture in the middle of the desert. Unfortunately, the security issue in the region after 2003 resemble a challenge to continue with building such dams, the dams in this area are:

1. Husub Dam: the dam is located on Husub Valley, southwest of Najaf. The length of the dam is $1050 \mathrm{~m}$ and its height is $11 \mathrm{~m}$. The size of the dam reservoir is 4.2 million cubic meters. It was completed in 2005.

2. Horan 2 Dam: it is located Horan Valley, northeast of the city of Rutbah. The dam is $650 \mathrm{~m}$ long and $14 \mathrm{~m}$ high and has a storage capacity of 4.9 million cubic meters.

3. Rutbah Dam: it is in the Western desert. It is an 848 meter long earth fill dam, and the height is $19 \mathrm{~m}$. The dam has a storage capacity of 32 million cubic meters. It was completed in 1981.

4. Al-Ubailah Dam: it is in the Western desert. It is a 500-meter-long earth fill dam, and the height is $11.5 \mathrm{~m}$. The dam has a storage capacity of 4 million cubic meters. It was completed in 1973. 
5. Al-Aghri Dam: it is in the Western desert. It is a 525-meter-long earth fill dam, and the height is $11 \mathrm{~m}$. The dam has a storage capacity of 6 million cubic meters. It was completed in 1974.

6. Hussainiyah Dam: it is in the Western desert. It is a 512-meter-long earth fill dam, and the height is $13.25 \mathrm{~m}$. The dam has a storage capacity of 6 million cubic meters. It was completed in 1976.

7. Shibaijah Dam: it is in the Western desert. It is a 720-meter-long earth fill dam, and the height is $10.5 \mathrm{~m}$. The dam has a storage capacity of 8 million cubic meters. It was completed in 1977.

8. Rahaliyah Dam: it is in the Western desert. It is a 440-meter-long earth fill dam, and the height is $13 \mathrm{~m}$. The dam has a storage capacity of 4 million cubic meters. It was completed in 1982.

9. Um Al-Tarfat Dam: it is in the Western desert. It is a 990-meter-long earth fill dam, and the height is $11.6 \mathrm{~m}$. The dam has a storage capacity of 7 million cubic meters. It was completed in 1982.

10. Surry Dam: it is in the Western desert. It is a 570-meter-long earth fill dam, and the height is $5 \mathrm{~m}$. The dam has a storage capacity of 0.3 million cubic meters. It was completed in 1976.

11. Abyadh Dam: it is in the Western desert. It is a 448-meter-long earth fill dam, and the height is $20 \mathrm{~m}$. The dam has a storage capacity of 25 million cubic meters. It was completed in 2002.

\subsection{Reservoirs in the natural depressions}

Reservoirs in the natural depressions are one of the earliest irrigation projects in Iraq in the 20th century, where the main concern of the irrigation authorities in the first half of the twentieth century was to confront the flood by the most possible means and the least expensive. The pioneers in this context were the British engineer William Wilcox and British experts who Introduced studies in this tendency.

The idea is to find an escape in the shoulder of the river, to lead the water to a nearby natural depression. This depression utilized to maneuver in the river system operation to absorb the peak of flood waves before permeating into the Mesopotamian plain and causing a loss of human beings and properties. Early plans had been putted in place for the implementation of the first two main projects, Habbaniyah on the Euphrates river basin, and the Tharthar project on the Tigris river basin (Wilcox, 1917). Further, Schweicha reservoir and southern marshes were developed later to serve as the same function.

\subsubsection{Habbaniyah Project}

Habbaniyah project was considered for a period as the main project to protect from floods on the Euphrates River, until Haditha dam had been built. The project was proposed in the recommendations of Wilcox in 1911, but the implementation delayed due to circumstance of the First World War (Sousa, 1944). 
Studies and designs continued after the formation of the Directorate General of Irrigation to utilize Habbaniyah depression, which is located east and southeast of the city of Ramadi. Then, implementation began in 1940, and due to the political events of May 1941 in Iraq, works were stood up. During the time between the formation of the modern state in Iraq and the 1940s, the Directorate General of Irrigation deliberately creates a fracture in the opening of the (Al Sitaieh) west of the city of Khalidiya city. Where for the period from 1924 to 1942, the openings were made eight times to pass the flood waves into Habbaniyah depression which was used to absorb part of the floodwaters (Sousa, 1966). The development of Habbaniyah Lake was initiated again in the early 1950s as part of the recommendations of the Heigh Advisory Committee; this committee was assigned to study the development of Tigris and Euphrates river basins (Commission, 1951). The implementation was carried out mainly under the supervision of Development Board, where this board commissioned in 1950 to invest the oil revenues in the development of Iraq infrastructure. The project was opened on 5/4/1956 (Sousa, 1966).

Figure 18 shows a general map of Habbaniyah project. The project consists the following:

1. Ramadi Barrage.

2. Warrar regulator and Warrar Canal.

3. Dhiban Regulator and Dhiban Canal.

4. Mijarrah Regulator and Mijarrah Canal.

5. Habbaniyah Lake.

6. Razzaza Lake or what is early know Abu Dibis depression.

Ramadi Barrage built on Euphrates River, upstream the city of Ramadi; the structure primary function is to raise water levels that required for operation of Warrar Regulator that divert water through Warrar Canal to Habbaniyah Lake. The Barrage length is $209 \mathrm{~m}$, and it consist 24 gates, their dimensions are $(6 \times 8) \mathrm{m}$, and the design discharge is $3600 \mathrm{~m}^{3} / \mathrm{s}$ at level of $51.5 \mathrm{~m}$ a.s.1. The structure includes a navigational look with dimensions of $(6 \times 40)$ and a fish ladder. 


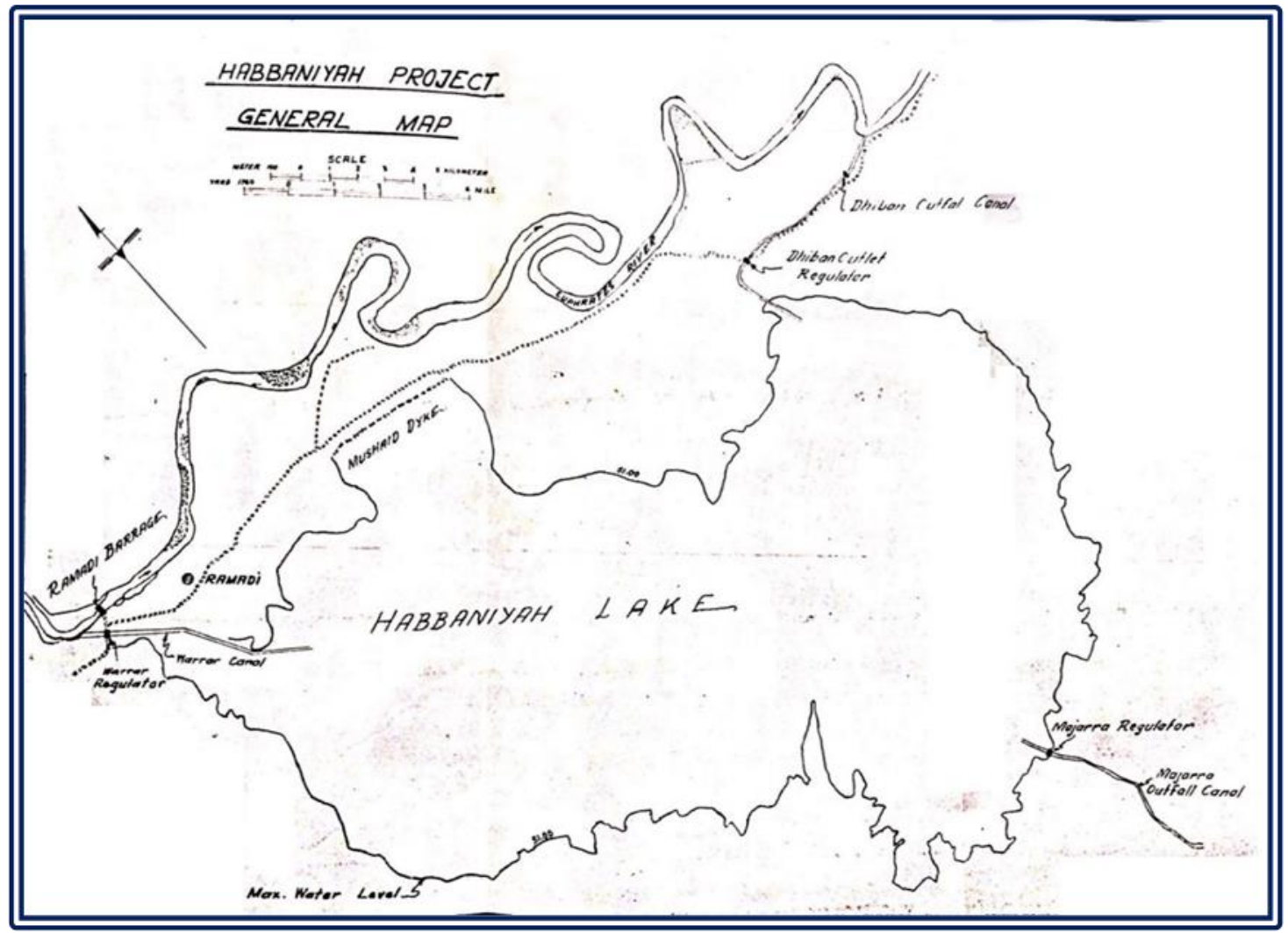

Figure 18: Habbaniyah project, a general map (D. Board 1955).

On the north-eastern edge of Habbaniyah Lake and Habbaniyah air base, the lake is connected with Euphrates River through Dhiban Canal, which has a length of about $9 \mathrm{~km}$, the discharges out of the lake is regulated by Dhiban regulator, which consists five gates with a dimensions of $(4.7 \times 5) \mathrm{m}$ and a discharge of $800 \mathrm{~m}^{3} / \mathrm{s}$. Also, on the south-eastern Edge of the lake there is Mijarrah regulator, which controls the discharge of excess water through Mijarrah Canal to Razzaza Lake. Mijarrah regulator consists 8 openings, could reach a maximum discharge of $1900 \mathrm{~m}^{3} / \mathrm{s}$ (Resources, 2005; Al-Simawi, 2014).

Regarding the lakes, the level of the bottom of Habbaniyah Lake is $36 \mathrm{~m}$ a.s.l, and the maximum operating level of $51 \mathrm{~m}$ a.s.l. the lake total storage is 3.28 billion cubic meters of which 2.72 billion is a live storage, while the surface area of the lake at the maximum storage level is $425 \mathrm{~km}^{2}$. Pertaining Razzaza Lake or what was called Abu Dibis or the Salt Sea, the lake role is to work as a floodwater reservoir from Habbaniyah Lake, the lake bottom level is $17 \mathrm{~m}$ a.s.l. and the maximum storage capacity is 25.75 billion cubic meters at level of $40 \mathrm{~m}$ a.s.l., and a surface area of $1810 \mathrm{~km}^{2}$.(Sousa 1966).

Although Habbaniyah system has an important role to mitigate the dangers of flooding and provide water for irrigation requirements, the construction of Haditha dam and the future construction of Baghdadi dam have a negative impact on project 
feasibility. Habbaniyah project among the most important proposed projects at the beginning of the twentieth century, at the time; no idea had been presented about a dam in the upper reach of Euphrates, where this had been raised during the stage of development board and the subsequent proposals of the Soviets consulting companies. One of Wilcox's proposals was also to re-use the storage of Razzaza Lake, as now Habbaniyah Lake utilized, but the detailed studies later do not recommended that.

The decline of water incomes in the Euphrates River had reflected on the water levels in Habbaniyah Lake, except the wet seasons. Also, this made a very large reduction in the limits and size of the Razzaza Lake, as shown in Figure 19 below. Finally, It's wise to mention that the drainage water of the Hussainiya irrigation project and parts of the Bani-Hassan irrigation project are pumped into Razzaza Lake.

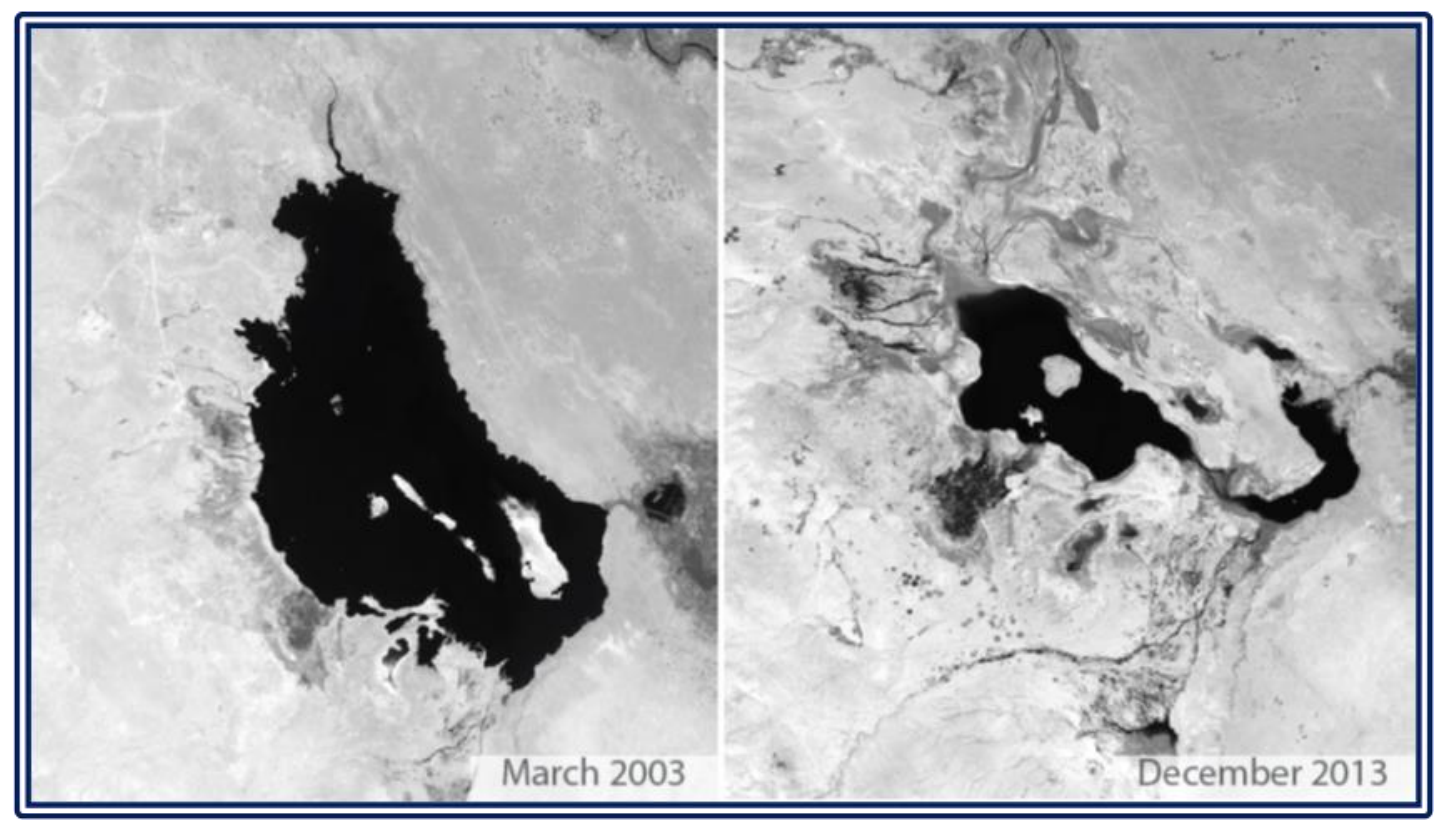

Figure 19: Comparison of aerial photographs of the size of Razzaza Lake between 2003 and 2013 (Iraq 2013).

\subsubsection{Tharthar Project}

Tharthar project is one of the strategic projects that have been carried out in order to mitigate the flood danger threating the city of Baghdad, where the frequent floods that affected the city and its residents contributed to make the issue of flood protection in Baghdad as a priority of the Iraqi government and the Directorate General of Irrigation. William Wilcox had chosen the site to be an escape to prevent flooding of Baghdad. Studies continued after Wilcox, and the implementation did not start until the establishment of the Development Board, this also coincided with the flood in 1954, which is the last flood that was sank parts of the city of Baghdad, 
this flood accelerated the decision to put in place the cornerstone of Tharthar Project (Sousa, 1966). The German company, Zublin, was entrusted to do the implementation of the structure, while Ransom and Rapier British Company carried out hydro-mechanical works. The works started in 1953, and the project was opened on 16/4/1956, where the water was passed to the Lake in the same month (Resources, 2005; D. Board, 1956). Figure 20 shows the elements of Tharthar and Habbaniyah projects. Tharthar project consists the following:

1. Samarra Barrage.

2. Tharthar regulator and Tharthar Canal.

3. Irwayah Canal.

4. Tharthar outlet regulator.

5. Division regulator.

6. Tharathar-Tigris and Tharathar-Euphrates Canals.

7. Tharthar Lake.

In order to divert the flood waves to the Tharthar depression, it was necessary to build a barrier on the Tigris River at the city of Samarra which is Samarra Barrage; it has a length of $252 \mathrm{~m}$ consisting of 17 openings $(12 \times 12)$ meters of dimensions. On the right side of the barrage, a hydro-power plant was installed with 14 units, with a maximum generation of $87 \mathrm{MW}$, the power station opened in 1971, there is also a fish ladder in the barrage. The maximum discharge of Samarra Barrage is $7000 \mathrm{~m}^{3} / \mathrm{s}$. The project also includes 4 irrigation openings, with a diameter of $2.5 \mathrm{~m}$, these lead to underground buried pipes feed the Main Canal of the Ishaqi irrigation project. 


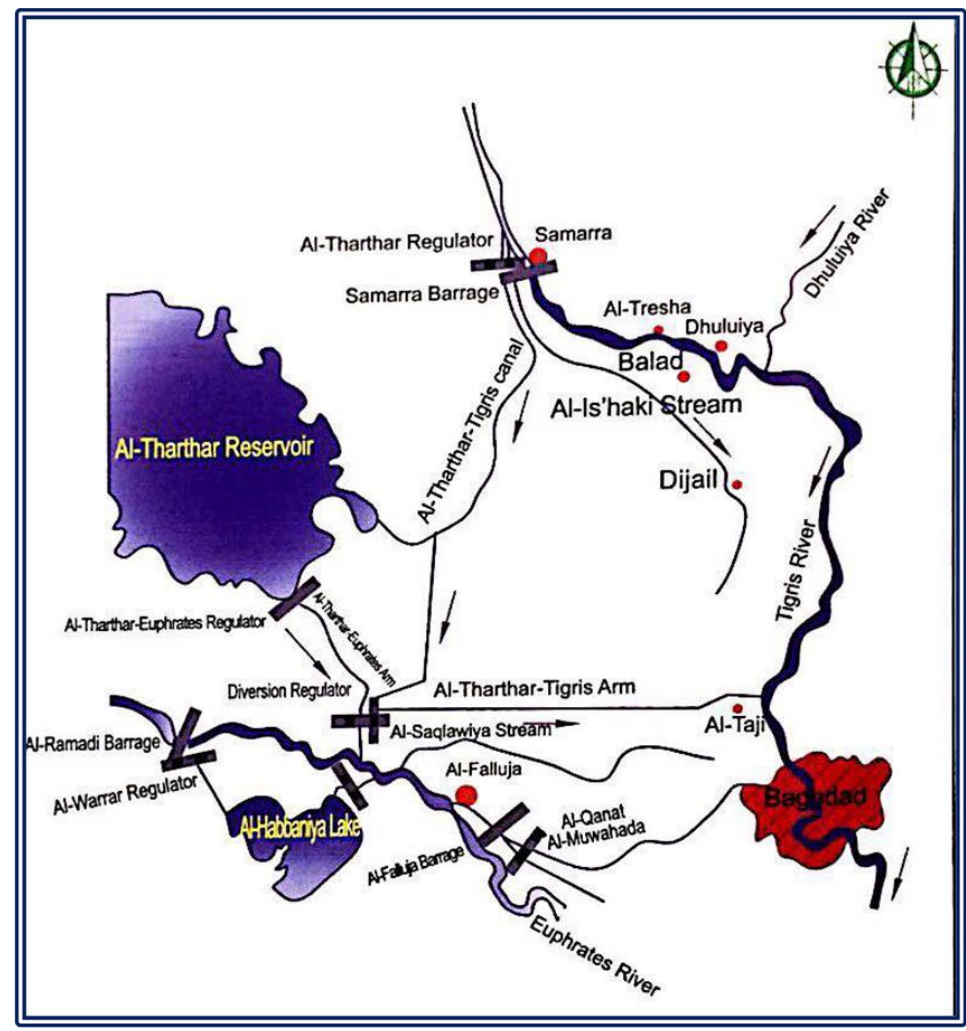

Figure 20: Tharthar and Habbaniyah projects (MoWR, 2005) between 2003 and 2013 (Iraq 2013).

The important part of the project is Tharthar regulator, which is basically the backbone of the project to divert flood waves to Tharthar Lake, the maximum discharge of Tharthar regulator is $9000 \mathrm{~m}^{3} / \mathrm{s}$, during the flood season in $2019 \mathrm{~m}$ there is approximately $1000 \mathrm{~m}^{3} / \mathrm{s}$ passed through the regulator. The structure consists 36 openings with dimensions of $(7 \times 12) \mathrm{m}$. The regulator discharge water to Tharthar Lake via the 65-kilometer-long Tharthar canal.

In 1991, two gates from the left of the regulator were isolated to feed the Irwaiyah Canal, which is an independent path with a discharge of $250 \mathrm{~m}^{3} / \mathrm{s}$ directly connected with Tharthar-Euphrates Canal at the upstream of division regulator. The Irwaiyah Canal is about $97 \mathrm{~km}$ long. Figure 21 shows the satellite view of Samarra Barrage and Tharthar Regulator (Resources, 2005; Al-Simawi, 2014). 


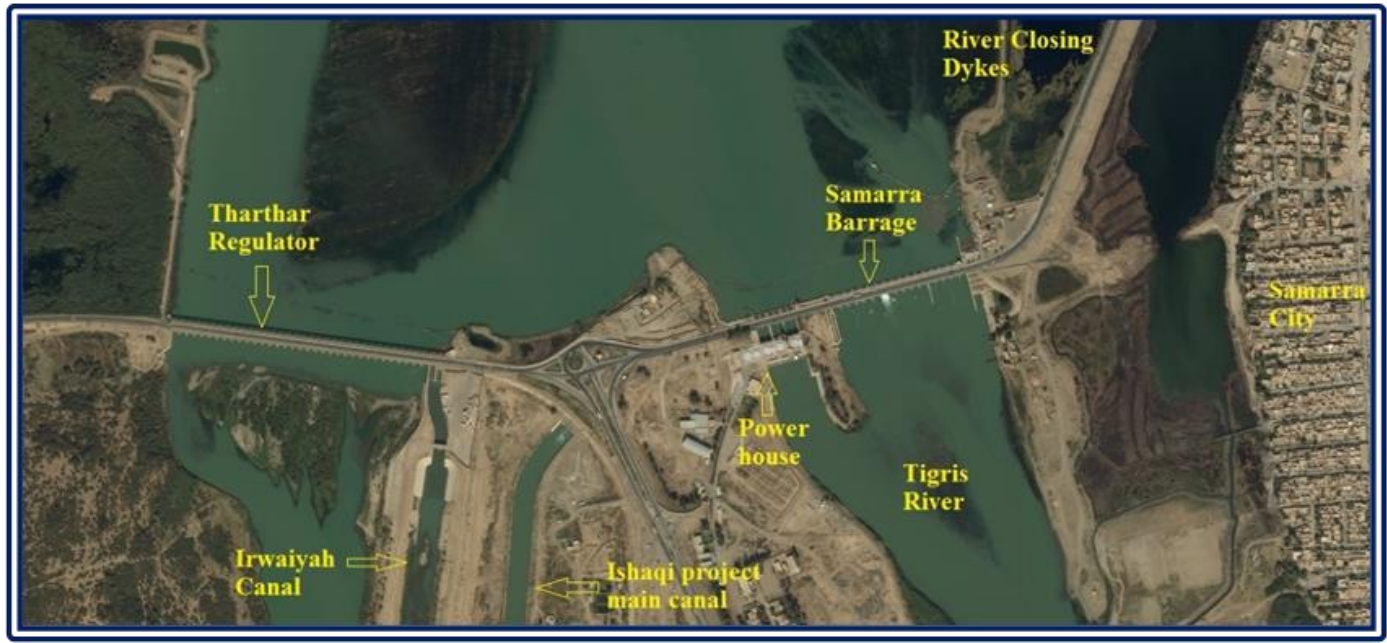

Figure 21: Satellite view of Samarra Barrage and Tharthar Regulator (Edited by Author; Esri n.d.).

The consultants who studied the Tharthar Lake did not agreed about the reuse of the reservoir storage during drought season. However, the decision finally made to dig the canals connecting Tharthar Lake with Tigris and Euphrates rivers. Started in 1972 Tharthar outlet regulator construction begun at the southern edge of the lake, and opened in 1976, the regulator includes 6 openings with a dimension of $(6 \times 8) \mathrm{m}$, and the maximum discharge of $1100 \mathrm{~m}^{3} / \mathrm{s}$. The bottom level of the regulator is $40 \mathrm{~m}$ a.s.l., below that is the dead storage (Sousa, 1966; Al-Simawi, 2014; Construction, 1989).

At the lower edge of Tharthar Lake and starting from the outlet regulator. ThartharEuphrates Canal start in a linear path for a $26.8 \mathrm{~km}$ till the division regulator, there, the division regulator comprised two partitions; on the left the first partition comprises 4 gates with dimensions of $(8 \times 7) \mathrm{m}$ and a discharge is $600 \mathrm{~m}^{3} / \mathrm{s}$, at this regulator, Tharthar-Tigris Canal starts and confluence Tigris River upstream of Baghdad city. The other part which built perpendicular to Tharthar-Euphrates Canal has 4 gates with dimensions of $(8 \times 7)$ and a discharge is $500 \mathrm{~m}^{3} / \mathrm{s}$, this regulator control the discharges on the Tharthar-Euphrates Canal which confluence with Euphrates River near Habbaniyah city. The length of the Tharthar-Euphrates Canal downstream the division regulator is $9.5 \mathrm{~km}$ long and the water was first diverted through the canal to the Euphrates River in 1976. Tharthar-Tigris Canal continues to the east for $28.5 \mathrm{~km}$, at this station, the drop regulator built, the function of regulation is to control the elevations and discharges, the drop regulator includes 4 openings with dimensions of $(8 \times 12.85) \mathrm{m}$ and a discharge of $600 \mathrm{~m}^{3} / \mathrm{s}$; Figure 22 is a downstream view of drop regulator. Downstream this regulator, the ThartharTigris Canal continues for $36.5 \mathrm{~km}$. Water was diverted through the canal for the first time in 1988 (Al-Simawi, 2014; Construction 1989). 


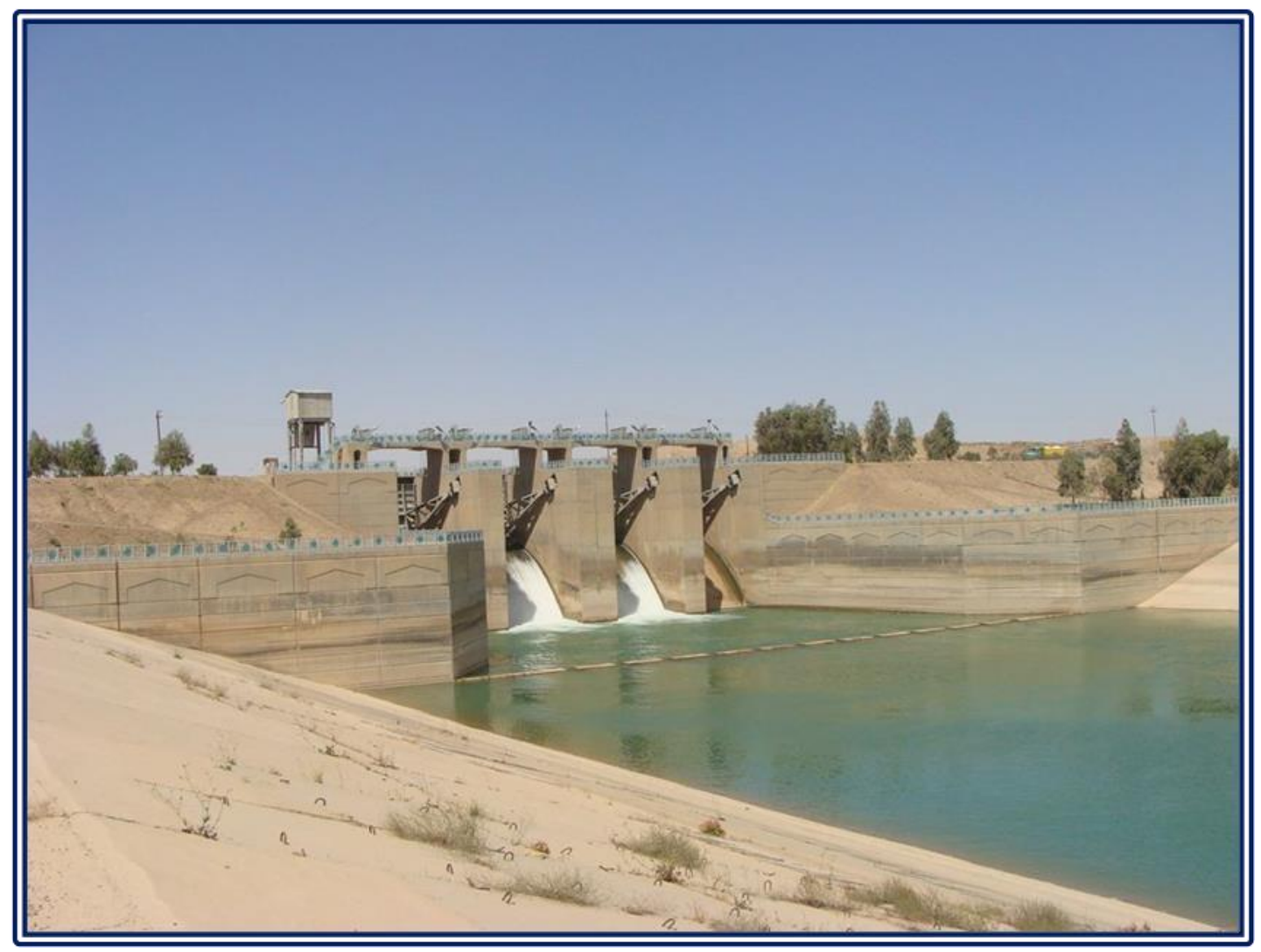

Figure 22: Downstream view of drop regulator on the Tharthar-Tigris Canal (MoWR n.d.).

Tharthar Lake is one of the largest natural depressions in the region, where it's located west of Samarra, the lake has a pear shape with a maximum length of $120 \mathrm{~km}$ and a maximum width of $45 \mathrm{~km}$. Tharthar depression is a natural feature believed to be caused due to karstification and continuous sinking of a subsurface graben. The bottom elevation of the lake $-3 \mathrm{~m}$ a.s.1, and the maximum elevation is $65 \mathrm{~m}$ a.s.l. (Sousa, 1966; Sissakian, 2011). The Lake is a natural continuation of Tharthar valley, which starts from the Sinjar Mountains, which runs north and then to the northwest, this valley drain the southeastern foothills of Sinjar Mountain, and there was a proposals about utilizing the catchment and harvesting the water in the valley before reaching Tharthar Lake, unfortunately; there were no measuring station for this promising valley. Nevertheless, an estimation during the rainy season 20122013 revealed that the upper reach of the valley before the confluence with Tharthar Lake has income about 141.7 million cubic meters at that season (Saleh, Abdulrahman, and Salih, 2017).

Tharthar Lake maximum capacity is 82 billion cubic meters at the level of 65 m.a.sl. The water has been diverted for many years, and the rate of incomes of the lake had been decreased after the commissioning of Mosul dam, and will decrease further after the building of Bekhme and Makhoul Dams. 
Ones of the main issues in Tharthar Lake are the evaporation and high salt content. The surface area of the lake is $1600 \mathrm{~km}^{2}$ at the bottom level of outlet regulator which is $40 \mathrm{~m}$ a.s.l., it rising to $2700 \mathrm{~km}^{2}$ at the operational maximum level $65 \mathrm{~m}$ a.s.l., also, evaporation at the maximum capacity is 7.4 billion cubic meter per year. Additionally, the high rate of evaporation, causes high saline concentrations of water in the lake, this is also caused mainly due to saline leaks from the bottom of the lake. The Directorate General of Industry analyzed water samples from Tharthar Lake when it was first started in operation. It was estimated that the lake had had a solution close to the saturation level before opening the canal for the first time in 1956 where the estimated quantity was 100 million cubic meters. After closing the canal after the first flood water passing, where it was closed on 5/5/1956, and after 24 days of closure, the salts concentration was $3.700 \mathrm{ppm}$, this increased on 20/11/1956 to $9360 \mathrm{ppm}$. After calculating the evaporation salts residual, it was concluded that the solubility of salts from the lakebed, most of which is sodium chloride, is the largest source of salinity in Tharthar Lake. (Industry 1957).

Energoprojekt company conducted in 1971, a study to analyze the salt balance within Tharthar Lake after thirteen years of commissioning, i.e; the period of 19571969. The results manifested that the evaporation from the lake is an additional factor affecting the salt accumulation, as the major contributor is the solution of the salts from the Lakebed. Table 1 shows an approximate contribution of various factors in increasing salt concentration within Tharthar Lake (Consulting Engineering Bearue, 2011). 
Table 1: An approximate contribution of various factors in increasing salt concentration within Tharthar Lake (Consulting Engineering Bearue, 2011).

\begin{tabular}{|c|c|c|c|c|}
\hline $\begin{array}{c}\text { Salt balance } \\
\text { in Tharthar } \\
\text { Lake }\end{array}$ & $\begin{array}{c}\text { Water } \\
\text { capacity } \\
\text { billion } \mathbf{~ m}^{\mathbf{3}}\end{array}$ & $\begin{array}{c}\text { Total quantity of } \\
\text { salt 10 } \mathbf{1 2}\end{array}$ & $\begin{array}{c}\text { Concentration } \\
\text { ppm }\end{array}$ & \% \\
\hline $\begin{array}{c}\text { Old Tharthar } \\
\text { depression till } \\
\text { Jan., 1, 1957. }\end{array}$ & 1.5 & 15.200 & 220 & 14.7 \\
\hline $\begin{array}{c}\text { Diverted Tigris } \\
\text { river from Jan., } \\
1,1957 \text { to Dec., } \\
\text { 31, 1969. }\end{array}$ & 68.6 & 17.200 & 250 & 16.7 \\
\hline $\begin{array}{c}\text { Evaporation } \\
\text { losses during 13 } \\
\text { years period }\end{array}$ & 30.6 & 7.600 & 100 & 6.7 \\
\hline $\begin{array}{c}\text { Bed and wall of } \\
\text { depression } \\
\text { lixivation from } \\
\text { Jan., 1, 1957 to } \\
\text { Dec., 31, 1969. }\end{array}$ & - & 65.000 & 930 & 61.9 \\
\hline $\begin{array}{c}\text { Salt in the } \\
\text { Tharthar Dec., 31, } \\
1969 .\end{array}$ & 70.1 & 105.000 & 1500 & 100 \\
\hline
\end{tabular}

Another aspect of Tharthar Lake is the proximity of the inlet mouth to the outlet regulator. This is reflected negatively on the mixing and the homogeneity of salt concentrations in the lake. (Al-Ta'i, 2015).

The years of drought that Iraq had experienced in 1999 and 2001, and after reaching the level of the lake below the bottom of the outlet regulator, the proposal of installing a pumping station to use the dead storage was presented. This idea was raised again after the dry season 2018, but the pumps did not install yet, although preparation works was partially completed.

\subsubsection{Shweicha Depression}

Shweicha depression is located east and northeast of Kut city, with the following main valleys feeding the depression: Wadi Harran, Wadi Shushrin, Wadi Al-Obeid, Wadi Tarsakh and Wadi Badra. The highest discharge achieved by these valleys is in the Wadi Badra where it reached $3500 \mathrm{~m}^{3} / \mathrm{s}$ (Saeed, 2018).

The depression bordered from the west by the chordal dykes that protects the city of Kut and Baghdad-Kut highway, the depression expands from the eastern side to some limits depending on season.

The idea of exploiting this depression was started at the beginning of the recommendations of the irrigation projects in the Wilcox proposals and the 
subsequent British consultants. Where the first idea was to divert part of the flood of the Diyala River, in addition to what flows from the floods of the eastern valleys and highlands from the Iranian side. These proposals have not been put into practice. The projects currently being built on the Diyala River are already has shortage in supply. Nevertheless, the depression continued to store water coming from the tributaries and discharge the water to Tigris river through Um Al-Jerie regulator which has a capacity to discharge $25 \mathrm{~m}^{3} / \mathrm{s}$. In addition, Nishama Escape also has a discharge capacity of $50 \mathrm{~m}^{3} / \mathrm{s}$, where this escape operates at a specific level during the high storage. Shweicha depression is widely spread and has a low height with a high rate of evaporation; the bottom level is $12 \mathrm{~m}$ a.s.l., and the maximum storage elevation is $15.4 \mathrm{~m}$ a.s.l. Estimates of storage are varying due to the lack of clear boundaries as well as sediments, however, the estimates indicate that they range from 400 to 500 million cubic meters. The depression also is a threat to the city of Kut in the event of collapse of the surrounding dykes on the west. The reservoir is important to supply irrigation requirements downstream Kut Barrage as well as improving navigation on the Tigris, putting in mind to utilize the storage in the same season to avoid evaporation losses. There is also a possibility of increasing the capacity of the reservoir by raising the western embankments. Finally, the case of development of Shweicha depression has a lack of sufficient data and comprehensive study of the area (Sousa, 1947; Hachim, 2018).

\subsubsection{Southern Marshes}

The marshes are one of prominent geographical features of the sedimentary plain. Figure 23 show a satellite view of Southern Marshes. Marshes area had shrunken often for multiple reasons, which are; the agricultural exploitation, the use of some as a balancing reservoir for the main drains, urban expansion, oil exploration as example in the eastern parts of Hammar marshes, security and military reasons, and the most important reason is the decrease in water quantities due to the riparian countries policies, especially after the 1990s. Areas occupied by marshes had compensated with the development of land for agricultural exploitation. That proposal of land reclamation had been raised earlier by British Consultants, namely; Heigh Commission, before the era of Development Board (Commission, 1951). After 2003, the policy of the Ministry of Water Resources changed to re-flood the marshes for livestock development, tourism and environmental purposes (Iraq, 2014). The role of marshes in flood control and the southern marshes resemble a survival system to the main cities in the south, especially Amarah city. Also, it is noted that there is no accurate and confirmed monitoring of the marshes, but only estimates. The area varies widely between the drought seasons and flood seasons due to the high rate of evaporation and the low depths.

Although several promising studies after 2003 were made pertaining re-flooding the southern marshes, where conclusions presented that re-flooding marshes will create invaluable opportunities in the socio-economic development, but none of these had made a proof. Hence, re-evaluating the southern marshes land and water use 
efficiency is very important, deeming the water income decrease, climate change, food security, water security, and achieving positive socio-economic impacts based on representative depiction.

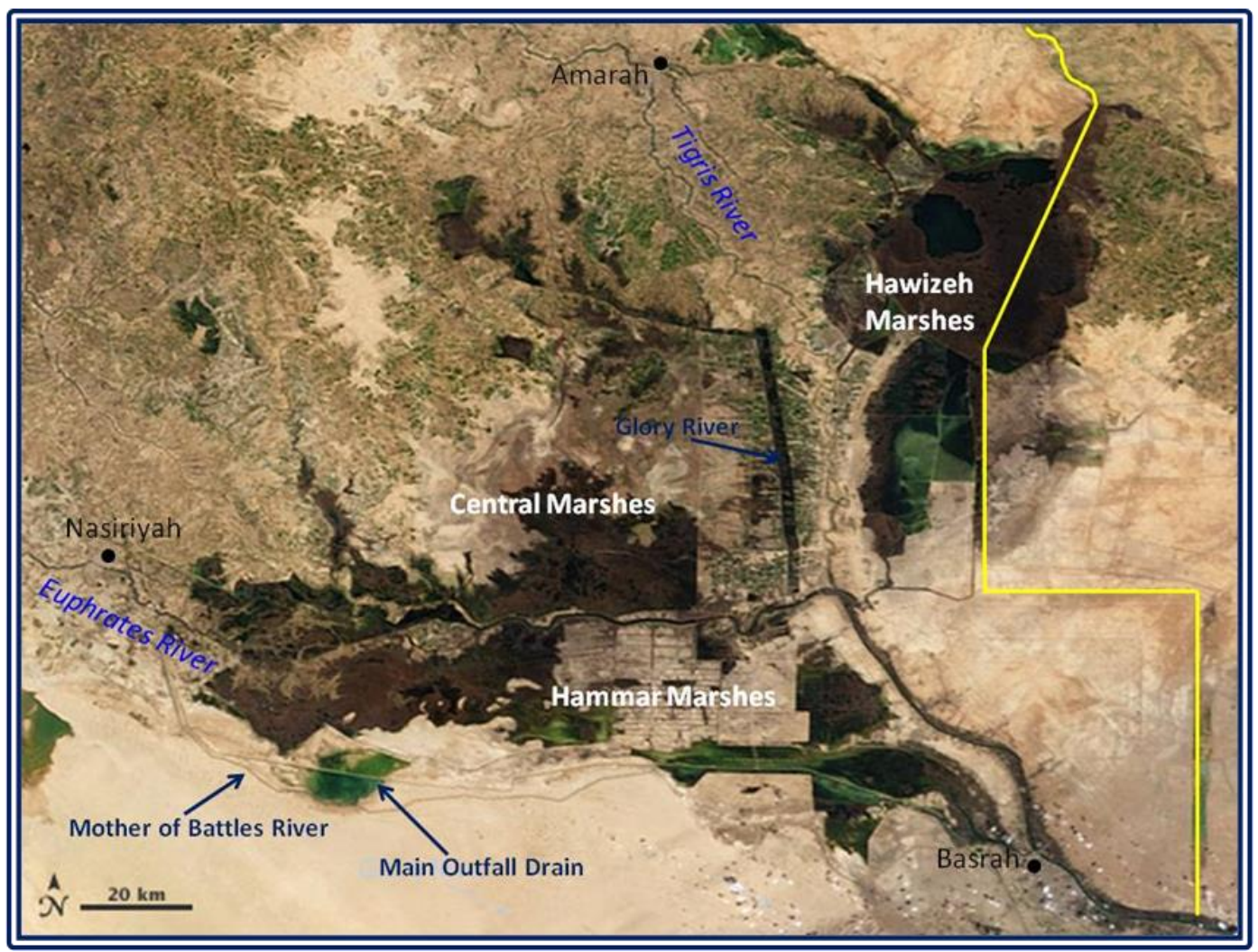

Figure 23: show a satellite view of Southern Marshes (Wikipedia n.d.).

There are three major marshes containing smaller marshes inside, which are:

\subsubsection{Hawizeh Marshes}

Hawizeh is the largest marshes, it's located in the province of Maysan on the left Tigris River, it's also a joint marsh with the Iranian side, and the major feeder of Hawizeh Marshes is Karkheh River, which originates from the Iranian side. Hawizeh Marshes area varies between (2500-1250) $\mathrm{km}^{2}$ between Iraq and Iran (K. H. Hassan, 2006). The exploitation by the Iranian side of the Karkheh River has reduced the area of Hawizeh Marshes. To drain water of these marshes, it effluent the water to the Tigris and Shatt Al-Arab through the Regulators, in order to maintain the water levels inside the marshes, these regulators are:

1. Kassara/Hawizeh regulator: to discharge water to Tigris River, this regulator is located near the city of Ezir. It consists 3 openings with dimensions of $(2 \times 2) \mathrm{m}$, and a side spillway of $65 \mathrm{~m}$ long, regulator discharge is $120 \mathrm{~m}^{3} / \mathrm{s}$.

2. Swaib regulator: to discharge water to Shatt Al-Arab, this regulator is located near the city of Quran. It consists 4 openings with dimensions of $(2 \times 2) \mathrm{m}$, and 
a side spillway of $140 \mathrm{~m}$ long, regulator discharge is $200 \mathrm{~m}^{3} / \mathrm{s}$ (Al-Simawi, 2014).

To mitigate the flood of Tigris River at the city of Amara, Kumait escape regulator constructed in the 1990s, which is located on the left bank of the Tigris River at 5 $\mathrm{km}$ upstream of Kumait city. The Regulator consisting 27 openings with a width of $3.5 \mathrm{~m}$ and a discharge of $400 \mathrm{~m}^{3} / \mathrm{s}$ (Zubaidy, Thamiry, and Khafaji, 2016). The regulator discharges the water to Sannaf marsh, which relates to Hawizeh Marshes. Figure 24 is an upstream view of Kumait regulator.

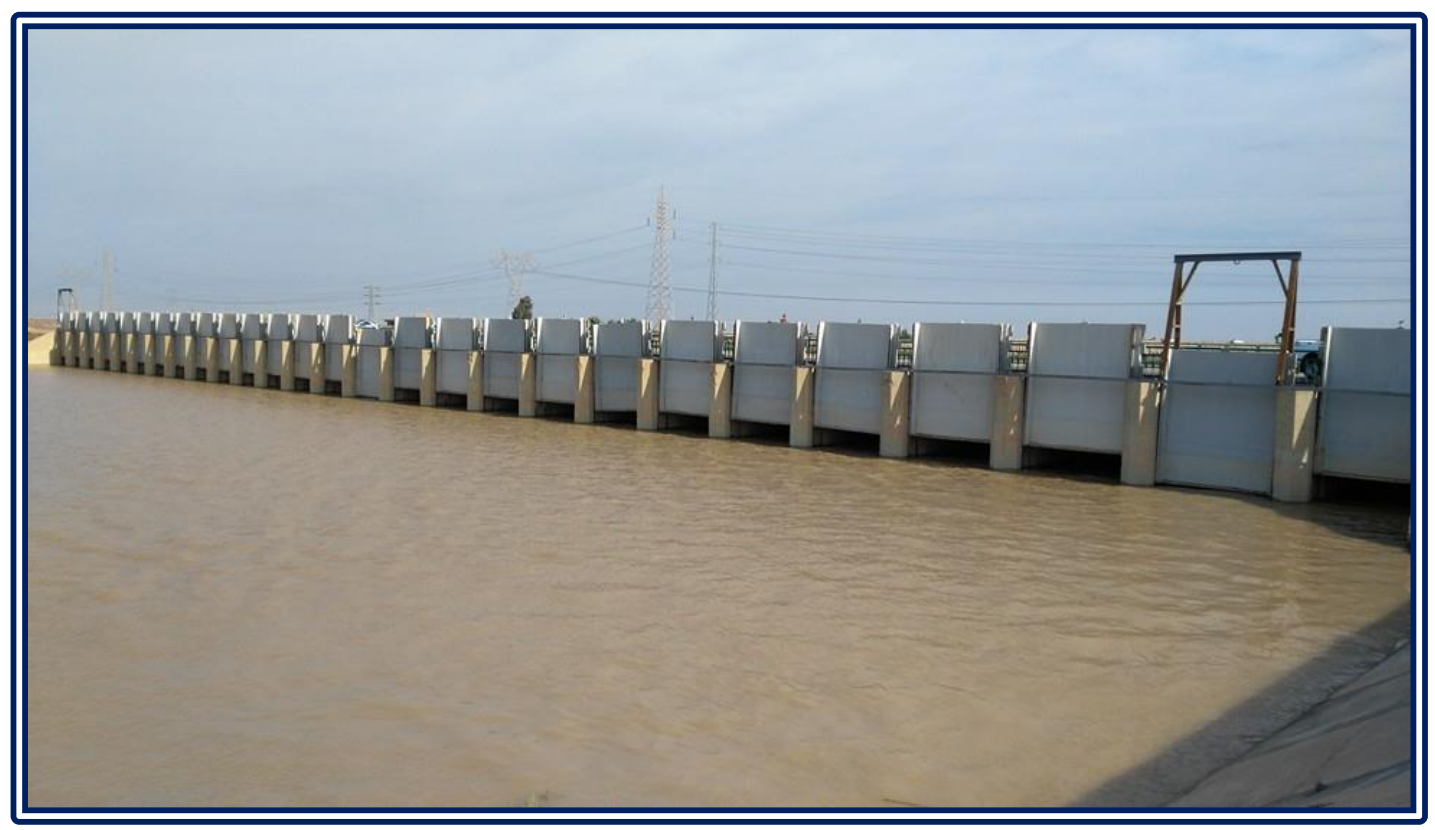

Figure 24: Upstream view of Kumait regulator (MoWR n.d.).

\subsubsection{Central Marshes}

Central marsh also called Qurnah Marshes, it's located within the provinces of Maysan, Basra and Dhi qar between the Euphrates and Tigris Rivers. Central marshes mainly connected with some branches of Tigris River on the right. The Central marshes area varies from $(2350-250) \mathrm{km}^{2}$ (K. H. Hassan, 2006). The most important flood protection escape connected with the central marshes is Musandag flooding escape, which lies to the right of Tigris River. Musandag escape diverts water through Musandag flooding course. Further, the flood waves are dissipated through Buteirah route, this route begin about $15 \mathrm{~km}$ upstream of Amarah city, the discharges to the route controlled by two regulator, namely; Buteirah and Eraidh, for both the design discharge is $700 \mathrm{~m}^{3} / \mathrm{s}$, while the route capacity is much less. During high floods, the Central Marshes overflow the Euphrates River, and connected with Hammar Marshes. The Central Marshes drained through several openings to Euphrates River, one of the most important of them is the outlet of Ezz River (Al-Simawi, 2014; Ministry of Irrigation, 1988). 


\subsubsection{Hammar Marshes}

These marshes located on the left of Euphrates River, connected with several branches downstream the city of Suq Al-Shuyukh. The surface area varies between (1650-595) $\mathrm{km}^{2}$ (K. H. Hassan, 2006). The end of the Hammar Marshes is linked to the Shatt Al-Arab in Grmat Ali, which is the ancient course of the Euphrates River. Dykes had been constructed to isolate the parts of Basra province from that of Dhi Qar province, the purposes of this is to protect oil facilities and to reduce salt concentrations in Shatt al-Arab.

\subsection{Barrages}

Barrages across Iraq are among the earliest built irrigation projects in Iraq. Across the main rivers in Iraq, many barrages had been built and others are under construction. These kinds of structures were constructed since the early time of civilization in Mesopotamia. In the modern history, the shortage of water in Hilla branch obliged Ottoman authorities to build Hindiyah Barrage across Euphrates. Later, William Willcocks recommendations that presented in 1911 had triggered the building of gated Hindiyah Barrage, Kut Barrage, Fallujah Barrage, Ramadi Barrage and Samarra Barrage. Only Hindiyah Barrage was built before World War I. Later in the 1930s, Kut Barrage was built. After commencing of Development Board in 1950s, Ramadi and Samarra Barrages were built, and Barrages in Euphrates lower reach. The works continued in 1960s to build other controlling structures, which are Dibis dam and Diyala Barrage. In the 1980s, New Hindiyah and Fallujah Barrages had built as well as Barrages in Kifl-Shinafiyah reach of Euphrates. Also, Amarah Barrage was commissioned in 2004.

\subsubsection{Dibis Dam}

Although Dibis Dam functioning as barrage, but due to the relatively high storage in term of medium capacity, hence it's named Dibis Dam, more precisely Dibis is a regulating dam. Dibis Dam construction coincided with the implementation of the Dokan Dam, where the idea is to maximize land exploitation that irrigated by Lesser Zab River within Kirkuk-Hawija-Adhaim irrigation project. Development Board has entrusted Binnie and Partners Company to conduct the study and design of Dibis Dam, then Polnesky and Zulner German Company was carried out the project and completed in 1965.

The dam lies near Dibis city, where the project includes 112-meter-long earth fill embankment, behind which a small lake with a capacity of 50 million cubic meters at elevation of $253 \mathrm{~m}$ a.s.l. this is the operational level. Concrete part in the dam is consisting 8 openings with dimensions of $(8 \times 11) \mathrm{m}$ which are controlled by radial gates; the gates could pass the maximum flood discharge of $4300 \mathrm{~m}^{3} / \mathrm{s}$. It also includes fuse-plug spillway, a saddle dam configuration on the right of the concrete partition. The saddle dam is constructed with crest elevation $25 \mathrm{~cm}$ lower than concrete part, to permit the water overflowing during the exceptional floods. Project also includes fish ladder. The earth fill part has a concrete core of $0.5 \mathrm{~m}$ width, the 
core shelled by earth fills, where the tallest height of the body is $22 \mathrm{~m}$.

Kirkuk irrigation project main regulator is a part of the project, this regulator was constructed on the left side of dam body. Kirkuk irrigation project main regulator composed 5 openings with dimensions of $(4.7 \times 7) \mathrm{m}$ controlled by radial gates, could pass maximum discharge of $300 \mathrm{~m}^{3} / \mathrm{s}$, at the maximum operational level. The total length of the project is $650 \mathrm{~m}$.

Dibis Dam was exposed to an overflow over the dam body in 1984 due to the occurrence of high flood wave downstream of Dokan Dam and a human error in the operation of the gates, as well as the accumulation of sediments upstream of saddle dam. A Chinese company between 1985 and 1987 had made the necessary repairs and the dam resume to operation (Sousa, 1966; Resources, 2005; Al-Simawi, 2010; USACE, 2003. Figure 25 shows a general view of Dibis Dam.

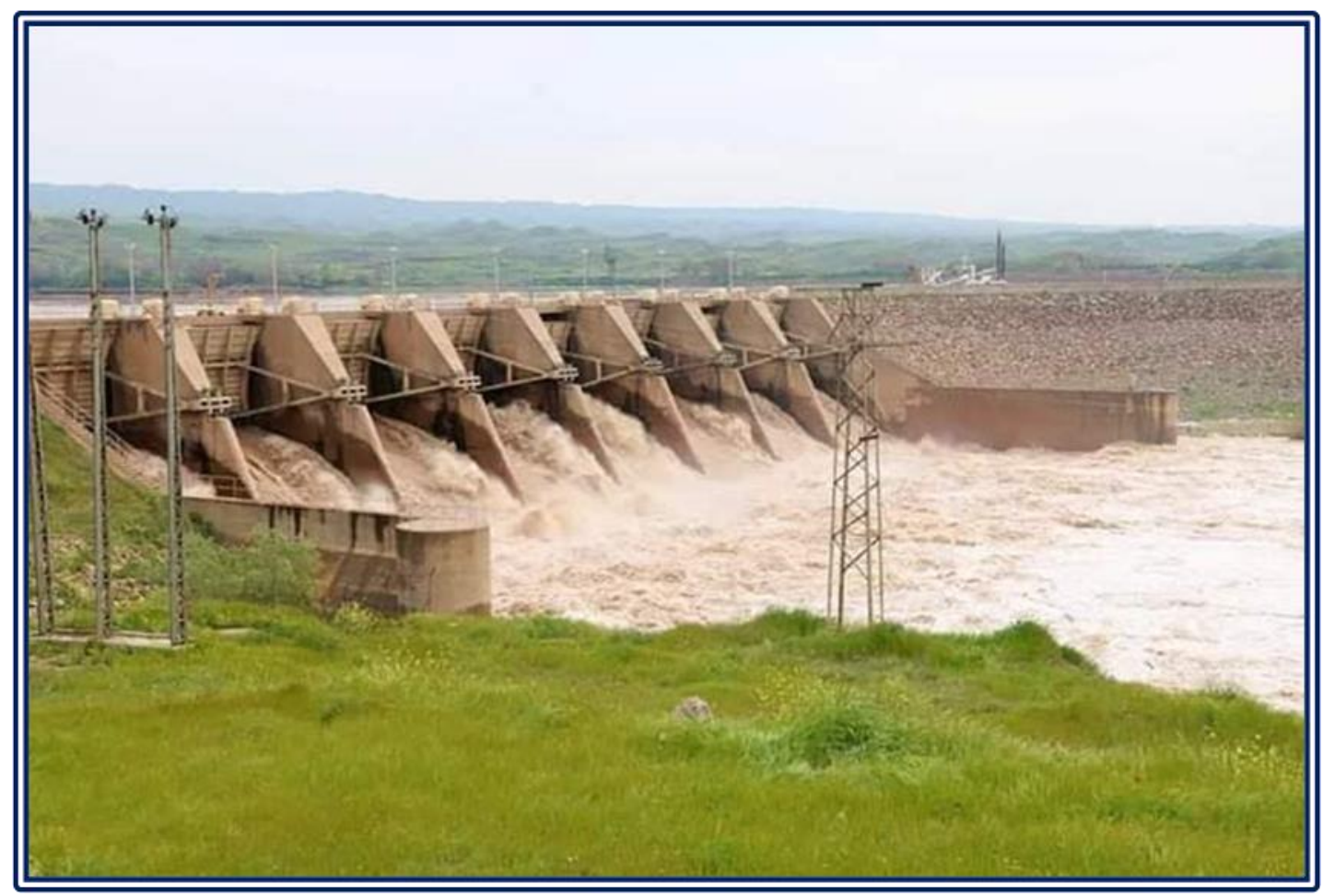

Figure 25: General view of Dibis Dam (MoWR n.d.). 


\subsubsection{Diyala Barrage}

Diyala Barrage is located on Diyala River at $7 \mathrm{~km}$ downstream of Hemrin Dam. This Barrage is serving the irrigation projects in Lower Diyala Area. Namely, Khalis irrigation project on the left and Combined Reach irrigation projects on the right, in addition to the orchards on both sides Diyala River and the municipal requirements of the cities and towns in the region. At the early times, a temporary dam was being built from trees and stone from time to time where it was going to collapse during flood seasons. In 1928, a semi-temporary weir was built, but soon it was collapsed in 1935. Another second weir was re-built between 1936 and 1940 and collapsed in 1946. As the interest in Diyala Basin raised and the construction of the Darbandikhan Dam completed, Sir M. MacDonald Company had been entrusted to study Diyala area, including Diyala Barrage. The company presented in 1963 a study of new gated barrage and head regulators for both Khalis Canal and Combined Reach Canal. Then, the implementation of Diyala Barrage by a Finnish company, the works completed in 1969.

The barrage is $400 \mathrm{~m}$ long concrete structure with 23 openings controlled by vertical gates has dimensions of $(2 \times 12) \mathrm{m}$, the discharge capacity is $1200 \mathrm{~m}^{3} / \mathrm{s}$ at elevation $67.5 \mathrm{~m}$ a.s.l. The main structure are including scour gates on both sides, the right side with three gates and the left side with five gates. All of scour gates have dimensions of $(2.5 \times 8) \mathrm{m}$, the scour gates have maximum discharge of $700 \mathrm{~m}^{3} / \mathrm{s}$. The emergency spillway was prepared on the left side upstream the barrage, in the case of exceptional high floods, the spillway has to lead water to Saladin flooding stream, which is connected to Shweicha depression. Diyala Barrage ensures water levels for two main head regulators, the dimensions of the openings of these regulators are $(2.5 \times 8) \mathrm{m}$, on the right, Khalis head regulator with 3 gates and maximum discharge of $75 \mathrm{~m}^{3} / \mathrm{s}$, while on the left, there is Combined Reach head regulator with 4 gates and maximum discharge of $126 \mathrm{~m}^{3} / \mathrm{s}$ (Resources, 2005; Al-Simawi, 2010; Directorate General of Irrigation, 1954). Figure 26 shows an aerial view of Diyala Barrage. 


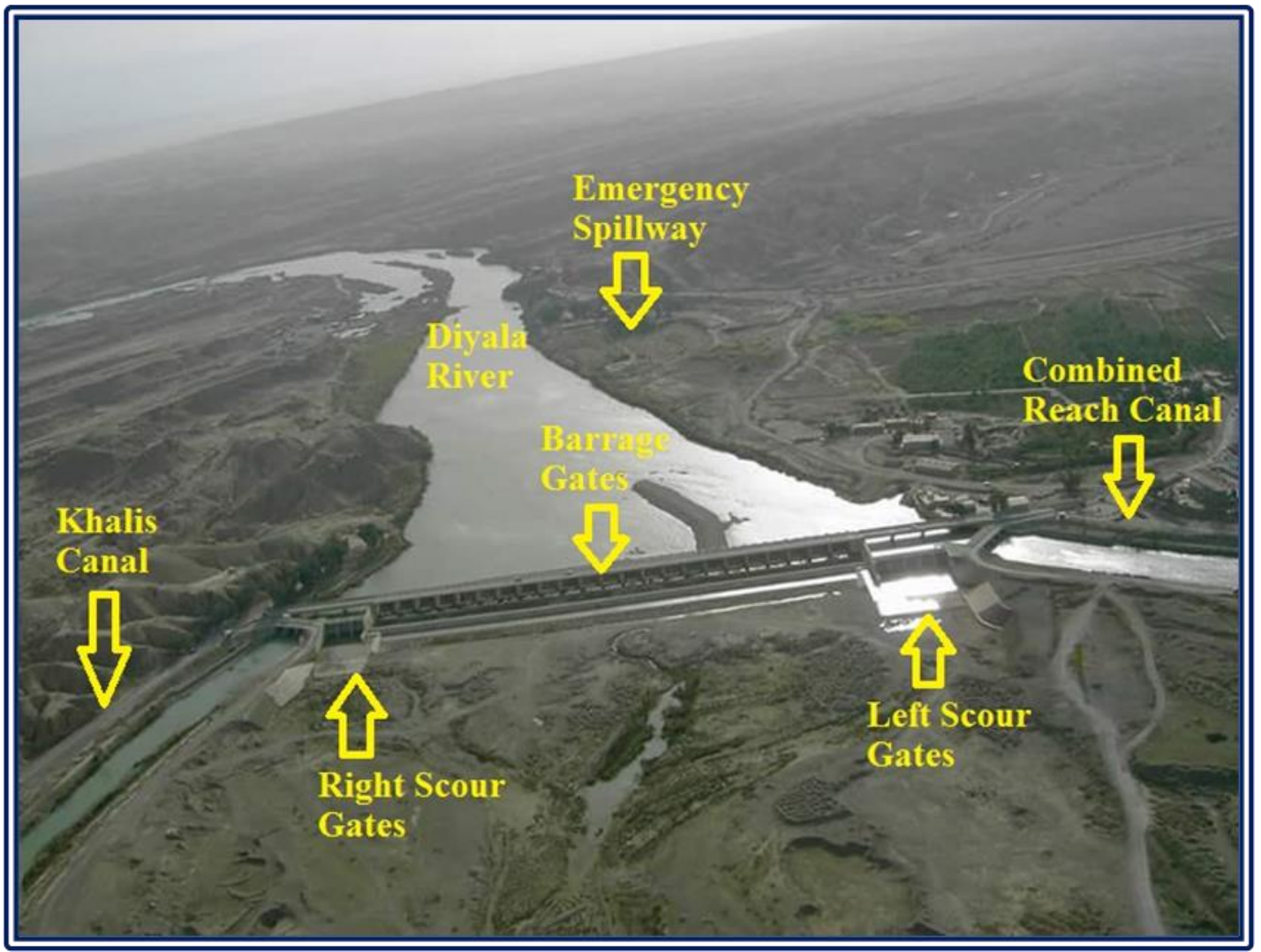

Figure 26: Aerial view of Diyala Barrage (MoWR n.d.; Edited by Author).

Among the main existing problems affecting Diyala Barrage is the excavation work in the adjacent quarries downstream the barrage, these excavations caused changes in the original river cross section. Changes in river cross section have hydraulically negative impacts in term of hydraulic jump location, where it had shifted away from the stilling basin. Scouring began to appear near barrage foundations. As a technical measure, concrete sill was constructed in the stilling basin in 2008 to contain the hydraulic jump within the basin. Excavations in the quarries continued up to date, and still resemble an evolving threat (Al-Simawi, 2010).

\subsubsection{Kut Barrage}

Kut Barrage is the oldest existing barrage on a main river in Iraq, had been suggested by Sir William Wilcox in his 1911 report, where the goal was secure water levels for Gharraf Canal. Sir Coode Wilson \& Partners Consultants undertook the necessary studies and designs as a result of its mandate to study the irrigation projects in 1930s. Construction works in Kut Barrage started in 1936 by the British company Balfour Beatty to carry out the civil works, while Ransom and Rapper had implemented the hydro-mechanical works. The Barrage opened in 1939. Kut Barrage was started to work at elevation of $16.75 \mathrm{~m}$ a.s.l. Later, when Middle Tigris projects had been under consideration, especially Dalmaj project, the barrage 
function was reassessed by Sir M. McDonald Consultant, where it was found necessary to ensure higher levels to ensure the project water supply. Consequently, the barrage modified to a new operational level of $18.5 \mathrm{~m}$ a.s.l. modification works was completed in 1967. Hence, Kut Barrage capable of providing water by gravity to Dujailah irrigation project, two branches of Dalmaj irrigation project, and Gharraf Canal.

Kut Barrage is a concrete barrier of $550 \mathrm{~m}$ long, comprising 56 openings controlled by vertical gates of dimensions $(6 \times 6.5) \mathrm{m}$ with a discharge capacity of $6000 \mathrm{~m} / \mathrm{s}$. On the right side of the barrage, there are fish ladder and beside the navigational lock of dimensions $(16.5 \times 80) \mathrm{m}$. It was vandalized by an air raid attack in 1991 and rehabilitated later by the Iraqi staff.

Dujailah main head regulator is a part of the project, the regulator is at distance 330 $\mathrm{m}$ upstream to the right of Kut Barrage, this regulator as opened with the project, then modified in 1978. It consists of two openings with dimensions $(5 \times 6) \mathrm{m}$ with maximum discharge is $42 \mathrm{~m}^{3} / \mathrm{s}$ and normal discharge is $35 \mathrm{~m}^{3} / \mathrm{s}$.

At $2 \mathrm{~km}$ right of the upstream Kut Barrage, there is Gharraf Canal head regulator. Which consists 7 openings of dimensions $(3.8 \times 6) \mathrm{m}$, in addition it has navigational lock with dimensions $(8 \times 80) \mathrm{m}$. Regulator maximum of is $500 \mathrm{~m}^{3} / \mathrm{s}$, the normal discharge is $350 \mathrm{~m}^{3} / \mathrm{s}$ (Sousa, 1966; USACE, 2003; Resources, 2005; Al-Simawi; 2010; Al-Simawi, 2014). Figure 27 shows a general view of Kut Barrage.

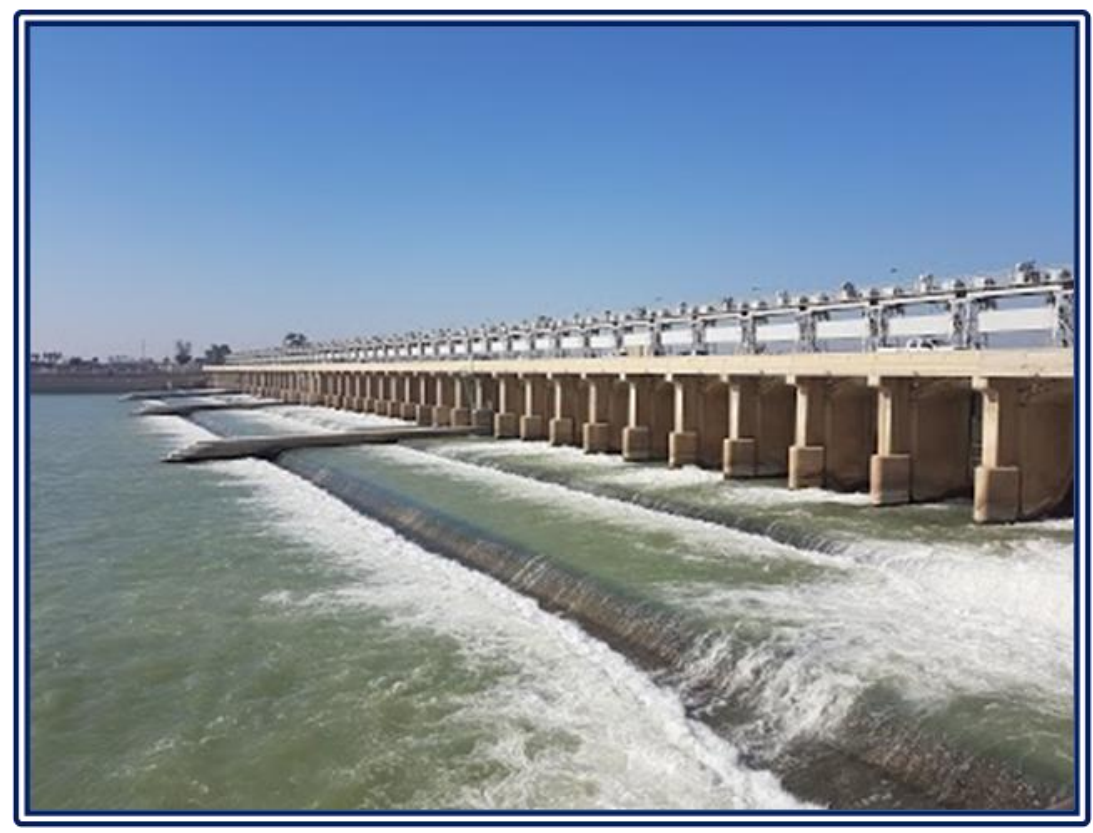

Figure 27: General view of Kut Barrage (MoWR n.d.). 


\subsubsection{Amarah Barrages}

One of the major irrigation projects in Iraq is Amarah great project, which a partially developed project. Project command area is within Maysan governorate, and it depends on the water of Tigris River where many old canals branched from the river. Development of the area was mentioned since Willcocks recommendations in 1911; he proposed the construction of barrages to assure the required navigational depths. The exploitation of Amarah land was assessed later by many consultants, the proposed barrages by consultants was to serve the irrigation purposes. There are three existing barrages across Tigris river, which are:

\subsubsection{Amarah Barrage}

This Barrage had been studied under Great Amarah project by the consultants Seigub and Khairallah Werdi, and the Indianan consultant WAPCOS was conducted the detailed design and submitted the final study in 1982. Construction of the barrage started in 2000 and completed the work in 2004. It consist 6 openings controlled by radial gates of dimensions $(6 \times 8) \mathrm{m}$ to pass discharge of $373 \mathrm{~m}^{3} / \mathrm{s}$. The body of the barrage includes fish ladder and navigational lock with dimensions of $(20 \times 217) \mathrm{m}$. Additional measures were subsequently implemented to protect the city of Amarah as well as the groundwater drainage system, but it was not completed, affecting the operational level, which was set to be $9 \mathrm{~m}$ a.s.l., where the current operational level is $6 \mathrm{~m}$ a.s.l. (Resources, 2005; Al-Simawi, 2010). Figure 28 shows a general view of Amarah Barrage.

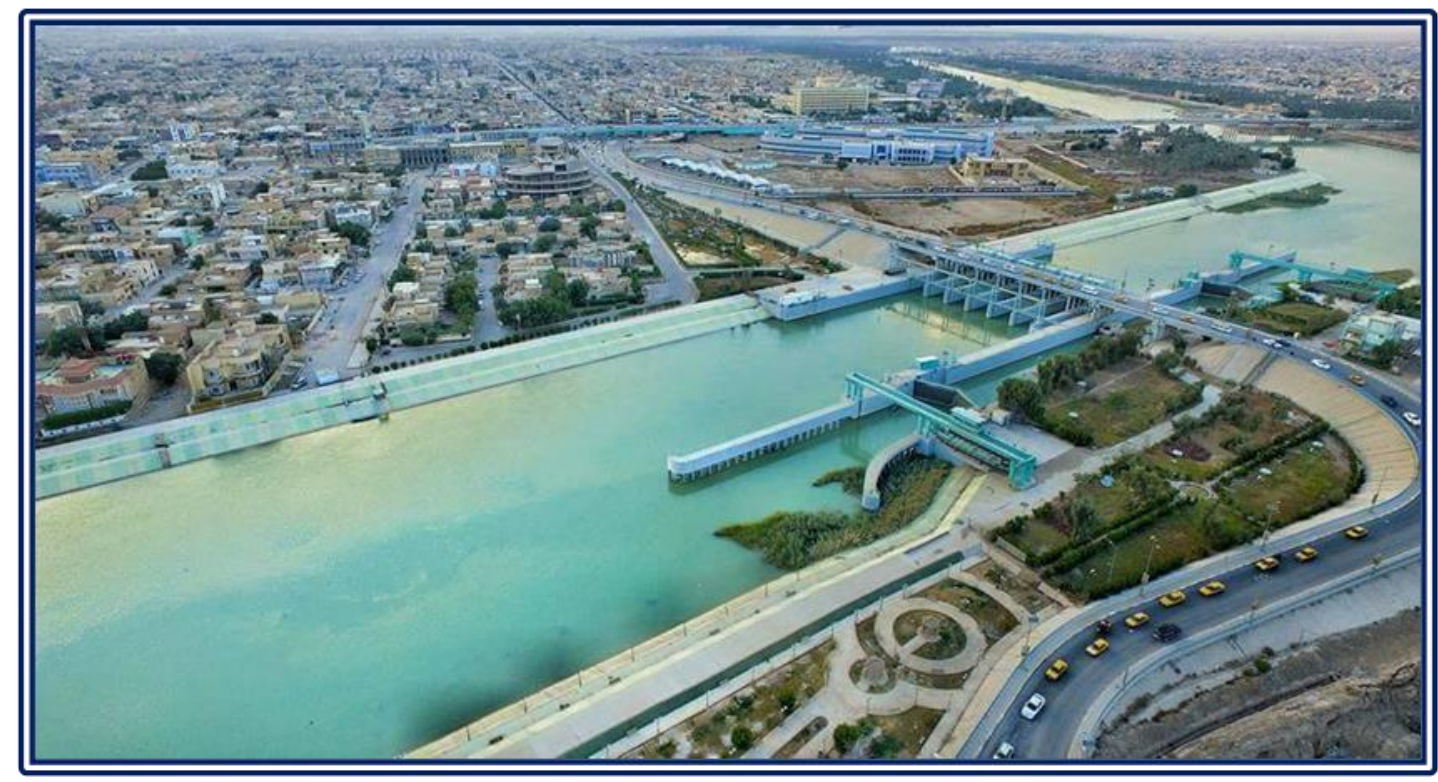

Figure 28: General view of Amarah Barrage (MoWR n.d.). 


\subsubsection{Qal'at Saleh Barrage}

Qal'at Saleh barrage is located near town of Qal'at Saleh on the Tigris, at a distance of $45 \mathrm{~km}$ downstream Amarah Barrage. It was implemented in 1978 and consists of 3 openings with dimensions of $(6 \times 8) \mathrm{m}$ and controlled by radial gates. The barrage includes fish ladder and navigation lock of dimensions $(16.5 \times 100) \mathrm{m}$. It has no sufficient and maintenance despite its existence on a main river.

\subsubsection{Kassara Barrage}

Kassara Barrage is located on the Tigris, at a distance of $70 \mathrm{~km}$ downstream Amarah Barrage. It was implemented in 1978 and consists of 3 openings with dimensions of $(6 \times 8) \mathrm{m}$ and controlled by radial gates. The barrage includes fish ladder and navigation lock of dimensions $(16.5 \times 100) \mathrm{m}$. The barrage is abandoned and needs a rehabilitation to resume to operation.

\subsubsection{Fallujah Barrage}

Fallujah Barrage considered as a part of Great Abu Ghraib Irrigation Project. The Barrage was first proposed to by William Wilcock in 1911 along with Euphrates left Canal, for the purpose of securing water levels to the left Euphrates branches from Saqlawiya to Iskandariya. At the beginning of 1970s, the interest raised about Great Abu Ghraib Irrigation Project. Hence, Selkhozpromexport Soviet Company had commenced to designs the barrage and presented the final report in 1978. Then, Barrage was opened in 1985.

Fallujah Barrage located at Euphrates River at a distance of 5 downstream the city of Fallujah. The barrage has 10 openings controlled by radial gates of dimensions $(8.5 \times 16) \mathrm{m}$; the maximum discharge is $3600 \mathrm{~m}^{3} / \mathrm{s}$ at the maximum operational level $44.79 \mathrm{~m}$ a.s.l. There is fish ladder, and the navigational lock is not implemented, supposed to be implemented in the future. The barrage rise the water to the Combined Canal, that feeding Great Abu Ghraib Irrigation project, this canal is branched from the left side of Fallujah Barrage, where the water discharged through the head regulator which consists of 4 openings of dimensions $(3.5 \times 6) \mathrm{m}$ and has operational discharge of $104 \mathrm{~m}^{3} / \mathrm{s}$.

The Barrage caused the rise of the groundwater level in some areas of Fallujah, which necessitated the establishment of a drainage system. It also suffered damage after the security events in 2014 (Resources, 2005; Al-Simawi, 2010; Al-Simawi, 2014).

\subsubsection{Hindiyah Barrage}

Water shortage in Hilla branch was triggered in the $2^{\text {nd }}$ half of 19 th Century; this was due to the closure of Saqlawiya Canal and the resulting increase of Euphrates discharge. Discharge increments of Euphrates caused scouring of the river bed downstream Hilla Canal branching. Hence, discharges increased toward Euphrates with less discharges in Hilla branch, sediments began to accumulate in Hilla branch bed and caused bed rise. Ottoman Authorities was taken measure at the last quarter 
of 19th Century, where the French engineer Schoenderfer was entrusted to find a solution.

Weir across Euphrates River was built, this weir could not withstand for long. After Willcocks intervention, he presented a design of new barrage with 36 openings of $5 \mathrm{~m}$ width each, the barrage was completed and opened in 1913. This barrage served for decades and passed several flood waves. Then, appeared that there was a need for a new barrage after the deterioration of the long-standing barrage.

Ministry of Irrigation entrusted the French company Sogreah to prepare the designs and studies, where it was initiated in 1978. Then the Chinese Engineering Company started the implementation of the dam in 1984 and completed in 1989. The new Hindiyah barrage project consists of main barrage, a hydroelectric station, navigational locks, and head regulators for Hilla Canal, Kifl Canal, Hussainiya and Bani Hassan Canal, as well as an administrative complex and a residential complex for the employees. Figure 29 shows the details of Hindiyah Barrage.

The new barrage is located $1.7 \mathrm{~km}$ upstream of the old barrage. It consists of the following parts:

1. Main Barrage: a concrete with 6 openings of dimensions $(6.75 \times 16) \mathrm{m}$ controlled by radial gates, maximum is $2500 \mathrm{~m}^{3} / \mathrm{s}$ at the maximum level is $32.55 \mathrm{~m}$ a.s.l. On the right side, there is hydroelectricity station comprises 4 units with a capacity of generating 15 megawatts and discharge $420 \mathrm{~m}^{3} / \mathrm{s}$. Beside the station, the navigational lock with dimensions of $(20 \times 150) \mathrm{m}$ and the fish ladder.

2. Hilla Canal main regulator: to the left of the main barrage is Hilla Canal main regulator which consists 6 openings with dimensions of $(5.4 \times 6) \mathrm{m}$ controlled by radial gates and passes maximum discharge of $326 \mathrm{~m}^{3} / \mathrm{s}$, while the normal discharge is $200 \mathrm{~m}^{3} / \mathrm{s}$, to the left of the regulator is an island within the river had being developed, where the project management building had built. To the left of the island, a 600-meter navigational channel linking Hilla Canal and Euphrates River and includes a navigational lock with dimensions $(6 \times 90) \mathrm{m}$. 


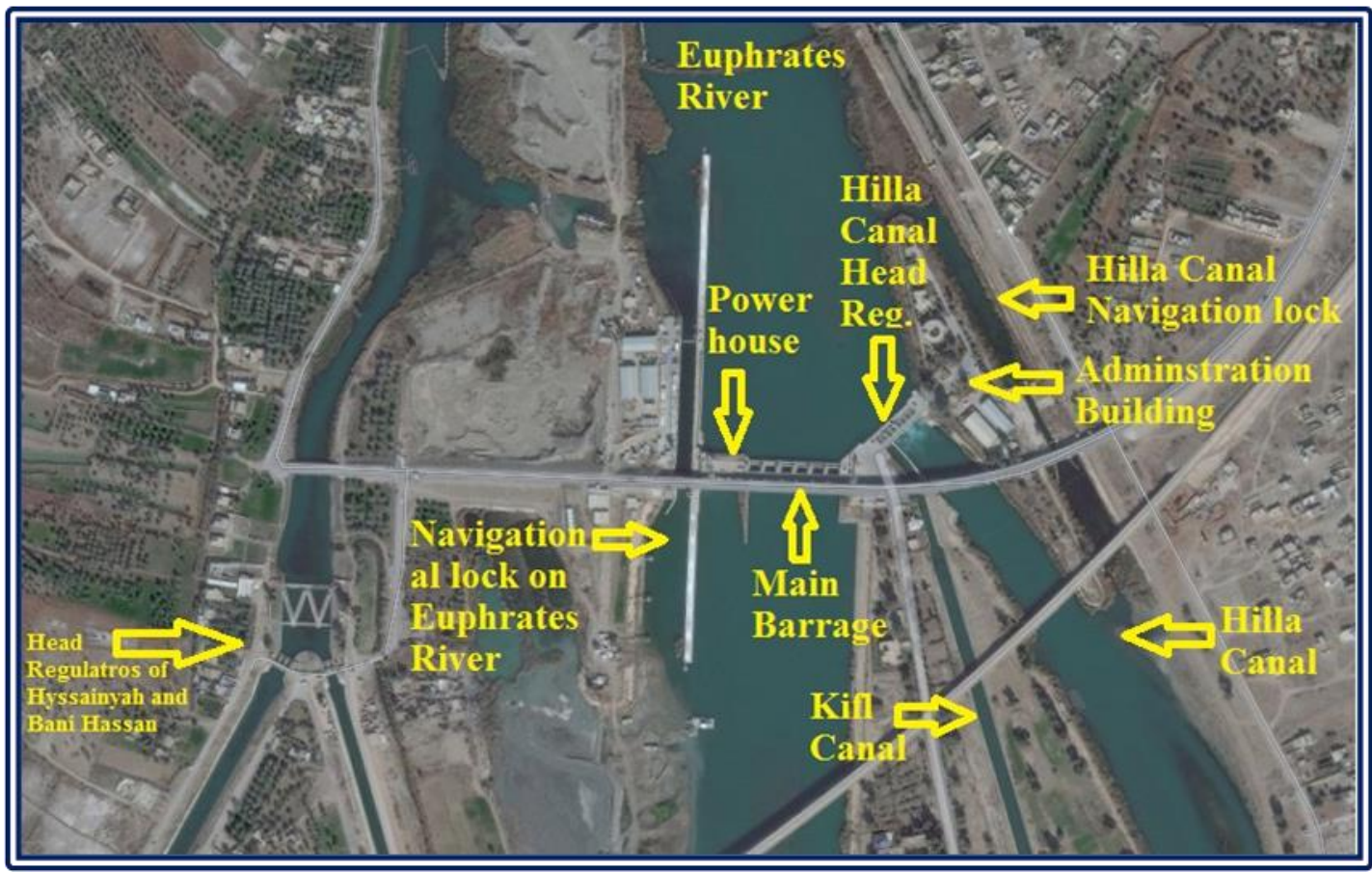

Figure 29: The details of Hindiyah Barrage (Esri n.d.; Edited by Author).

3. Kifl Canal head regulator: this regulator is between the main barrage and Hilla Canal main regulator, it consists two openings with dimensions of $(3.4 \times 4.5) \mathrm{m}$, maximum discharge is $36.12 \mathrm{~m}^{3} / \mathrm{s}$, while the normal discharge is $20 \mathrm{~m}^{3} / \mathrm{s}$.

4. Bani Hassan head regulator: to the right side of the main barrage, there is the closure dykes of the abandoned river reach, then a joint canal leading to the head regulators of Hussainiya and Bani Hassan Canal. Bani Hassan head regulator consists two openings with dimensions of $(3.4 \times 6) \mathrm{m}$ and the maximum discharge is $45 \mathrm{~m}^{3} / \mathrm{s}$.

5. Hussainiya head regulator: it lies right of Bani Hassan head regulator. It consists of 3 openings with dimensions of $(3.4 \times 6) \mathrm{m}$. the maximum discharge of the regulator is $55 \mathrm{~m}^{3} / \mathrm{s}$, and the normal discharge is $32 \mathrm{~m}^{3} / \mathrm{s}$.

6. Fish protection meshes: in order to prevent passing of fish to the irrigation courses, a $1 \mathrm{~cm} \times 1 \mathrm{~cm}$ meshes were installed. The first mesh is at Kifl Canal head regulator with dimensions $(2.5 \times 24) \mathrm{m}$, while the second is at upstream of Hussainia and Bani Hassan head regulators, it was installed in configuration as the letter (W), length of $36 \mathrm{~m}$ and height of $5 \mathrm{~m}$. It is connected to a course to return water to Euphrates River.

7. Infrastructures: include a project management building, a residential complex for workers and a railway bridge for Musayab-Karbala railway (Resources, 2005; Al-Simawi, 2014; Al-Simawi, 2010). 


\subsubsection{Kifil-Shinafiyah Barrages}

Kifl-Shinafiyah irrigation project is one of the major projects in Iraq in terms of area and population. Euphrates River passing across the project through two main branches. Namely, Shamia Branch and Kufa Branch. Several Barrages were built in different times. Which are:

\subsubsection{Shamiya Branch regulators}

Downstream Kifl city, Euphrates River is branching into two streams, to the left Shamiya Branch, and to the right Kufa Branch, Regulators were built across Shamiy Branch to rise the water for the irrigation canals. In this branch the regulators are without navigation locks as the main stream considered for navigation is Kufa Branch. The regulators on Shamiya Branch are:

1. Abbasiyah Regulator: it is the first regulator on Shamiya Branch, located upstream of Abbasiyah city. Sogreah French Company had designed this regulator with others in the area, while Chinese company for construction engineering was implemented this structure with other regulators in 1980s. Abbasiya regulator was opened in 1988, it consists 6 openings of dimensions $(6.3 \times 12) \mathrm{m}$ controlled by radial gates and pass maximum discharge of $1100 \mathrm{~m}^{3} / \mathrm{s}$. The regulator also has a fish ladder.

2. Shamiya Regulator: it is located upstream of Shamiya city at the station $39 \mathrm{~km}$ of Shamiya Branch, was opened in 1986 consists of 6 openings of dimensions $(6.3 \times 12) \mathrm{m}$ which are controlled by radial gates and its' maximum discharge $1100 \mathrm{~m}^{3} / \mathrm{s}$. The regulator has a fish ladder.

3. Khawarnaq Regulator: it is located upstream of Ghamas city at the station 69 $\mathrm{km}$ of Shamiya Branch, was opened in 1986 consists of 5 openings of dimensions $(8 \times 8) \mathrm{m}$ which are controlled by radial gates and its' maximum discharge $1100 \mathrm{~m}^{3} / \mathrm{s}$. The regulator has a fish ladder.

\subsubsection{Kufa Branch Barrages}

The Barrages and Regulators built on this branch are:

1. Kuafa Barrage: It is the first structure on Kufa Branch, with the same companies that had designed and built the hydraulic structures in 1980s in the area, Kufa Barrage was opened in 1988.Kufa Barrage has 7 openings with dimensions of $(6.3 \times 12) \mathrm{m}$ controlled by radial gates passing maximum discharge of $1400 \mathrm{~m}^{3} / \mathrm{s}$. The regulator includes a fish ladder and a navigational lock with dimensions of $(20 \times 150) \mathrm{m}$. The barrage includes also a hydroelectric power station with 4 units generating 6 megawatts. Figure 30 shows a general view of Kufa Barrage. 


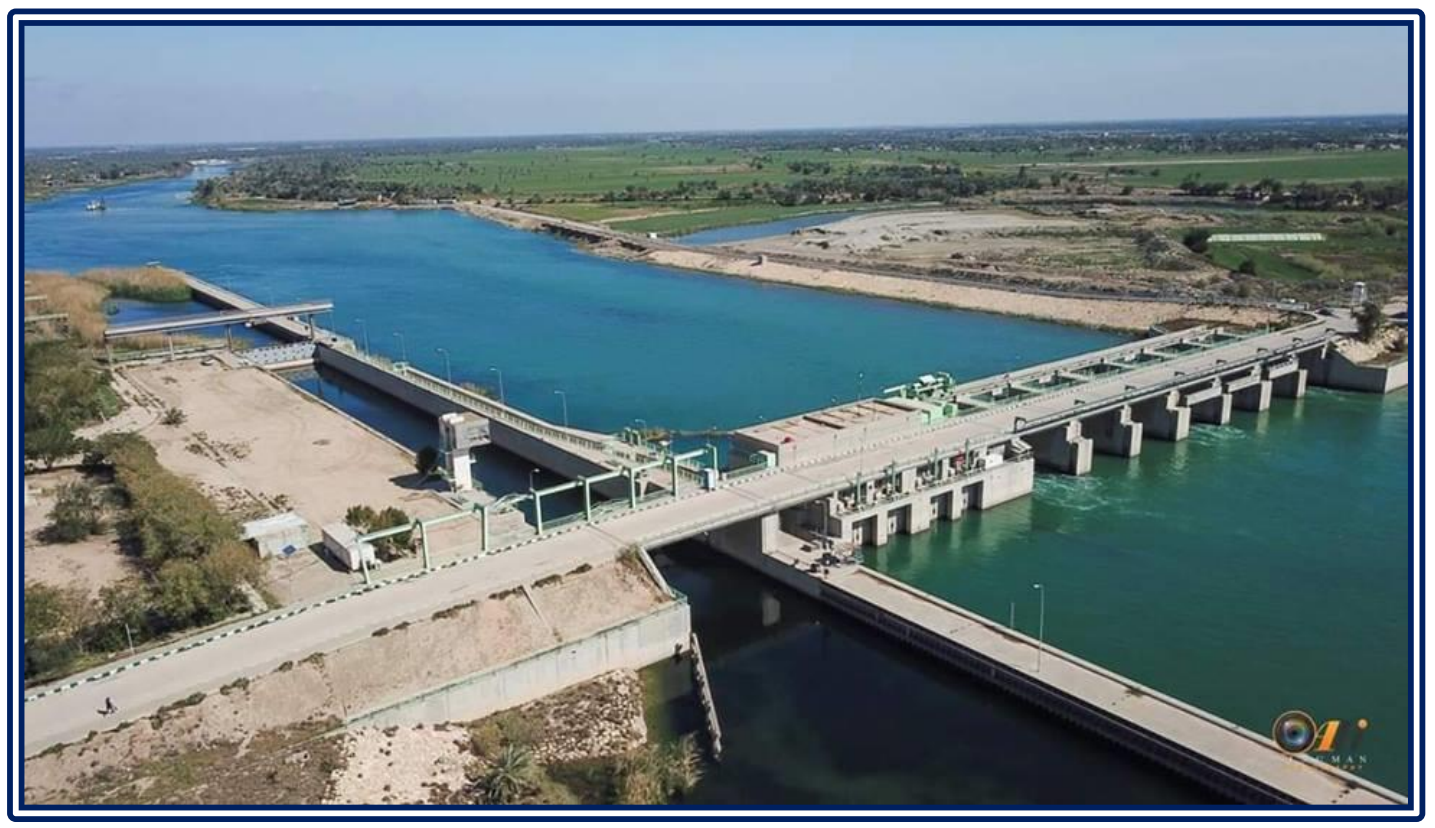

Figure 30: General view of Kufa Barrage (MoWR n.d.).

2. Meshkhab Barrage: This structure is located in Meshkhab city, where it was completed in 1959. The barrage consists 7 openings has width of $12.55 \mathrm{~m}$ controlled by vertical gates and pass maximum discharge of $750 \mathrm{~m}^{3} / \mathrm{s}$. It includes a fish ladder and a navigational lock with dimensions of $(8 \times 80) \mathrm{m}$.

3. Abu Ashraa Regulator: is one of the long standing regulator located near Qadisiyah sub-district. It was completed in 1936, a drop structure had been added also and completed in 1939. The regulator is composed of 4 openings with dimensions of $(2.5 \times 3) \mathrm{m}$ controlled by vertical gates; the maximum discharge is $50 \mathrm{~m}^{3} / \mathrm{s}$. On the left of the regulator there is navigation lock with dimensions of $(6 \times 105.75) \mathrm{m}$.

4. Al-Ya'aw Regulator: It is also one of the old regulators, which is located on the beginning of Al-Ya'aw River, which branches from the upstream of Abu Ashraa regulator at $5 \mathrm{~km}$ to the left. This regulator was completed by the governing company Balfour Beatty in 1940 and is composed of 7 openings with dimensions $(2.5 \times 3) \mathrm{m}$, the maximum discharge is $200 \mathrm{~m}^{3} / \mathrm{s}$ (Resources, 2005; Al-Simawi, 2014; Al-Simawi, 2010; Directorate General of Irrigation, 1954).

\subsubsection{Lower Euphrates Reach Hydraulic Structures}

When Euphrates River passing Near Souq Al-Shouyokh city, it's branching to several branches. Many hydraulic structures where built in the late 1950s and 1960s, to control the water distribution in the farmlands. The main control structures in this reach of Euphrates River are:

1. Ghlewen Regulator: Ghlewen Branch is branching from Euphrates River at a 
distance of $9 \mathrm{~km}$ upstream of Suq Al Shoyokh city. This branch confluence with Euphrates River again near Al Fuhood sub-district. The discharges of the branch were controlled by Ghlewen Regulator, which consists 5 openings discharged $250 \mathrm{~m}^{3} / \mathrm{s}$, the regulator was built in 1968 .

2. Ekaikah Barrage: Safha Branch is starting from the left of Euphrates River at approximately $2 \mathrm{~km}$ upstream Suq Al-Shoyokh city, the length of Safha branch is $10 \mathrm{~km}$ and at the end There is Ekaikah Barrage, which consists of 5 openings of discharge $300 \mathrm{~m}^{3} / \mathrm{s}$, the barrage has a fish ladder and navigational lock with dimensions of $(8 \times 60) \mathrm{m}$. Right of Ekaikah Barrage, there is Garmat Hassan Regulator, which has 3 openings have discharge capacity of $100 \mathrm{~m}^{3} / \mathrm{s}$. Both Structures were opened in 1957. Downstream, Ekaikah Branch is confluence with Ghlewen branch, while Garmat Hassan Branch is confluence with Euphrates River at Al-Taar city.

3. Haffar Barrage: it is the last Barrage on Euphrates River before confluence with Tigris River in Qurna. The Barrage was built near Bani Se'id city in 1957 and consists of 7 openings have discharge capacity $500 \mathrm{~m}^{3} / \mathrm{s}$, in addition to fish ladder and navigational lock has dimensions $(8 \times 60) \mathrm{m}$ (Al-Simawi, 2014; AlSimawi, 2010).

\subsection{Irrigation Project on Tigris River}

Irrigation projects on Tigris River are existing centuries ago, as the example of Ishaqi, others are depending on pumping. After Samarra, all the projects built with drainage networks, where many discharge to Main Outfall Drain or to Tigris. Development stages covered many projects upstream Kut Barrage, but this does widely occurred in the lower Tigris or in Gharraf area yet. However, Gharraf projects, Great Amarah project and Shatt Al-Arab project are an important pending projects to enhance socio-economic conditions, food security and environmental aspects.

\subsubsection{Jazeera Irrigation Project}

It is one of the most important strategic projects in Nineveh governorate; the project's land is located within areas with good rain and good soil and is suitable for the establishment of complementary irrigation projects to maximize the production of the winter season, mainly grain. There were initiatives of thinking about Jazeera project with studies of Mosul Dam, where it was planned where the reservoir would feed the surrounding land as well as other lands to the south. Development Board issued its resolution on July 7, 1956, under which it commissioned the U.S. Kuljian Company to study the possibilities of land development around Mosul Dam reservoir, and a year later the company submitted a proposal to invest $1,037,000$ dunams in three sectors north, east and south, named respectively North Jazeera, East Jazeera and South Jazeera.

The northern part is located northwest of Mosul and extends to Rabiaa and is fed through a pumping station on the right side of Mosul Dam Lake. The southern 
section is located south-west of Mosul city and draws its water from a structure within the dam and passes through a number of tunnels, the most important of which is the tunnel beneath Mount Sheikh Ibrahim, while the eastern part of the project irrigates the plains of Nineveh east of Tigris through the flow of water from the lake through a tunnel, and this section includes the lands irrigated by pumping at the areas at confluence of Great Zab River with Tigris River.

Nedeco Company subsequently prepared the project designs, project implementation were delayed as Mosul Dam project delayed where the implementation started at the beginning of 1985 , when a Chinese company began implementing its first part, North Jazeera Irrigation Project.

Northern Jazeera irrigation project net area is estimated to be 240,000 dunams irrigated by sprinklers, which is in the form of a horizontal strip to irrigate the irrigation unit. Water is pumped into the project through a pumping station submerged in the Lake of Mosul Dam, and this station is unique as it is a capsule of concrete in an oval form within internal diameter of $60 \mathrm{~m}$ and an internal height of $25 \mathrm{~m}$ and thickness of the walls $2 \mathrm{~m}$, the station sucks the water by three openings. There were 12 pumping units distributed diagonally to raise water with design discharge of $34 \mathrm{~m}^{3} / \mathrm{s}$. Through two steel pipes, the water discharged to the stilling basin, which forms the beginning of the main canal. There is also a 130-metre-long service tunnel connecting the station to the lake bank and includes a cabin moved on railway to reach the capsule. The station was implemented by The Korean Company Hank Yung. Figure 31 showing views of the pumping station of North Jazeera irrigation project. 


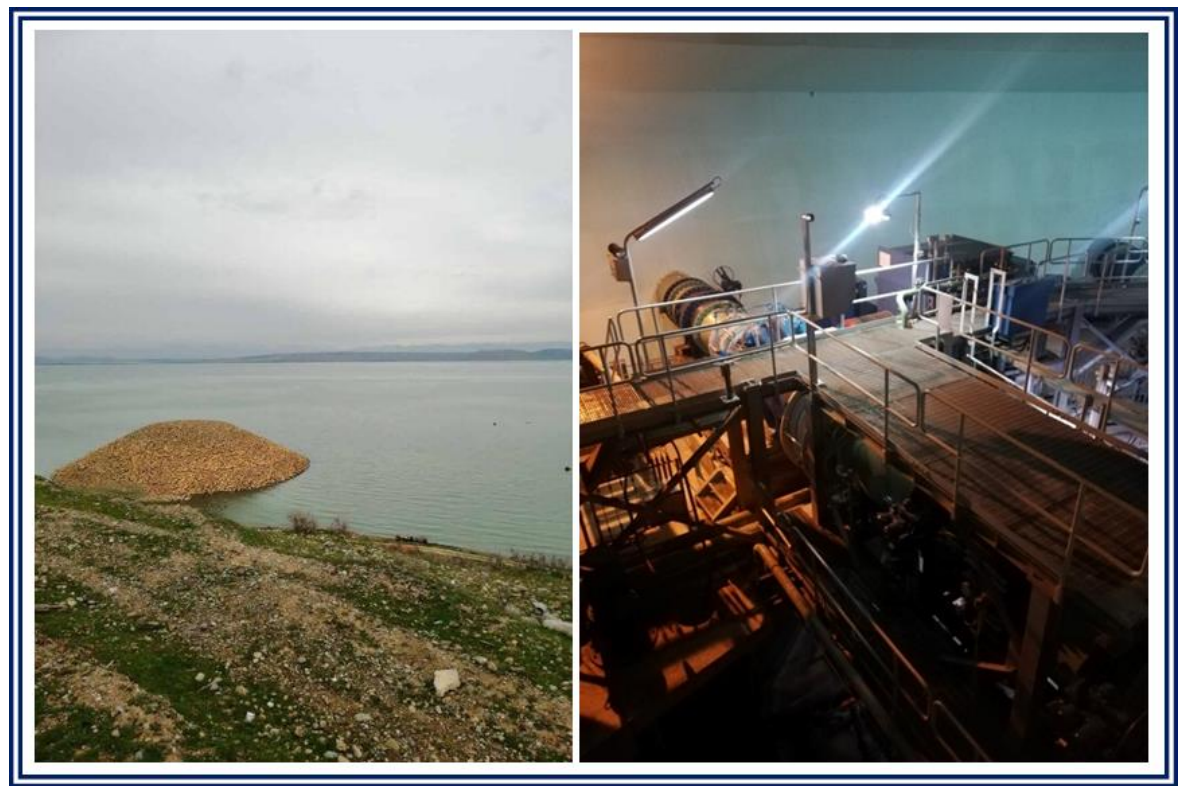

Figure 31: The main pumping station of North Jazeera Irrigation Project. a) Right: The image of the pumping station from the outside is stacked above with stone to resist the buoyance force of the water. b) Left: A picture of the pumping station from the inside (MoWR n.d.).

Water is pumped into the main canal from which many sub-canals are branching, all of which are lined with concrete. Within the project there are two other pumping stations, the first is the Tel Al-Hawa pumping station, which includes 5 pumping units with capacity of $6.3 \mathrm{~m}^{3} / \mathrm{s}$ for the pumping unit, and the second is a pumping station with two pumping units with capacity of $6.3 \mathrm{~m}^{3} / \mathrm{s}$ for each unit. These two pumping stations were equipped with Technopormexport brand pumps.

The project consists of two stages; the first was implemented for irrigation by sprinklers and using sprinklers of the brand (Valley), the area is 157 thousand dunams, and the second within area of 83 thousand dunams irrigated by gravity initially, started to equipped with sprinklers of the brand (Bauer). The sprinklers were vandalized and looted following the security events of 2014. The project does not include field drains, but rather drains water through the natural streams of the area. The project's system gates are Avio and Avis self-propelled type.

The project and pumping stations were mainly vandalized and looted after the events of 2014, and rehabilitation work continues with the support of international organizations.

Within Ease Jazeera project, Salamiyah Irrigation project which is a small project with net area of 7,000 dunams located along Tigris River in Hamdaniya district near Nimrod ruins. The project irrigated by a pumping station that draws water from Tigris River and includes 5 metric pumping units and 5 half-metric pumping units. Project's land is watered by a $12.3 \mathrm{~km}$ main canal and a $7 \mathrm{~km}$ branch canal, and the project does not include drains, as the land naturally drains into Tigris River. 
The project area and pumping station were vandalized after the events of 2014, and the project and the station were reconstructed by humanitarian organizations.

East Jazeera project also includes Zab Irrigation project, which feeds from a pumping station on Great Zab River, where the station has six metric pumping units. The station is located at the village of Abzach and raises the water to a main canal that lasts $12.7 \mathrm{~km}$ from which two branch canals, 6 and $9 \mathrm{~km}$ long, branch. The irrigation system in the project is the pivot and horizontal sprinklers, where the project was started in 1993 and stopped, the resumed in 2005. Also, the sprinklers do not cover the entire area of the project, which amounts to 14,000 dunams, and the project does not include field drains. The pumping station for this project was also vandalized following the security events of 2014 and was rehabilitated by NGOs.

The part of East Jazeera which feeds directly from Mosul Dam Lake, which is the largest part with net area of 215,000 dunams, was started in 2012. Works were hold due to the events of 2014 as well as the national financial crisis. The 800,000 dunams South Jazeera project is still a future project (Resources, 2005; Al-Simawi, 2010; Al-Simawi, 2011; Sousa 1966)

\subsubsection{Small Irrigation projects in Upper Tigris}

Several projects on Tigris River are along, from the south of Biji to the north of Baghdad, which are small projects, the projects generally in the form of a pumping station built on Tigris that feeds a main canal watering the lands near the river, sectors of these projects were studied for the first time by the so-called Naifa Irrigation Project, where Engineers Dr. Ahmed Sousse and Vahi Sevian in 1971 submitted the planning report of the project to the Supreme Agricultural Board and was aimed at studying the land to the left Tigris River in the governorates of Samarra and Tikrit. What was diagnosed in the first studies is the presence of gypsum in the soils, which necessitates the lining Canals to prevent collapsing.

Some projects were subsequently implemented, which included in the studies and other projects as follows:

1. Alam Irrigation Project: The project covers the land located west of Alam city and adjacent to Tigris River and bordered to the south by the Tikrit-Kirkuk road, the net area of the project is 18,000 dunams, the project has been designed and studied by the general establishment of studies and designs and was implemented by the Turkish company Kaska and commissioned in 1985. The project is fed from Alam pumping station on Tigris River, which has a discharge of $3 \mathrm{~m}^{3} / \mathrm{s}$. The water is raised to a $16.85 \mathrm{~km}$ concrete main canal, from which concrete flumes are branching. There are no field drains, but rather natural streams that drain water into the Gulf and Al-Aly valley which flows into Tigris River, the other name of the project is Gulf and Al-Aaly.

2. Albu-Ajil Project: An extension of the land of the Alam project to the south of Tikrit-Kirkuk road. The project covers land with net area of 6,000 dunams. Water is pumped into the project through the Albu-Ajil pumping station on Tigris River, which includes a metric pumping unit and four half-metric 
pumping units.

3. A'wja Project: The project's land is located east of A'wja area in the land adjacent to the right of Tigris River. The project was implemented in 1983 to cover a net area of 6,500 dunams, which is watered from Tigris River by a pumping station of $2.5 \mathrm{~m}^{3} / \mathrm{s}$ discharge capacity.

4. Owainat Project: The land of Owainat is located to the south of the city of Awaja, the right of Tigris River, and feeds from a pumping station with 4 half-metric pumping units to cover an area of 10,000 dunams.

5. Tigris Project: The land of project is located to the east of Tigris district and right to Tigris River within area of 11.5 thousand dunams, the project was implemented in 1984. It is fed from a pumping station on Tigris River with 6 pumping units with capacity of $1.15 \mathrm{~m}^{3} / \mathrm{s}$.

6. Dur project: The project land is located in Dur district and has a net area of 8,000 dunams. The project is fed by a pumping station with discharge of $1.5 \mathrm{~m}^{3} / \mathrm{s}$.

7. Rasasi Project: The project's land is located east of Samarra, where the project was completed through the revival of the old Rasasi River and part of the old Nahrawan stream. The project is fed by gravity from Tigris River through head regulator which intersects with Samarra-Tikrit highway; the regulator has two openings and a discharge of $18 \mathrm{~m}^{3} / \mathrm{s}$. It was completed in 1996. The main canal, which has been revived, is $34 \mathrm{~km}$ long and is planned to irrigate an area of 120,000 dunams, the current area being less. The project was completed within the current phase in 2001.

8. Duloiya Project: it is located near the confluence of Adhaim and Tigris Rivers within the Duloiya area, water is pumped into the project, which is covered by a network of earth canals through a pumping station on Tigris River which includes 3 metric pumping units to meet the needs of the 25,000 dunams project.

9. Nai Project: A reclaimed project, where the land of the project is located to the left of Tigris River, the project feed from a pumping station on Tigris River located $8 \mathrm{~km}$ downstream from the confluence of Adhaim and Tigris Rivers, pumping station discharge is $9 \mathrm{~m}^{3} / \mathrm{s}$. The net area of the project is 28,000 dunams. The project includes a $20.6 \mathrm{~km}$ main canal and two boosting pumping stations are located within the canal's path to raise water. The project drains its lands to Tigris River through drainage network. The project was designed and implemented by the Land Reclamation Establishment, which was started in 1976 and completed in 1983. The project is currently neglected and deteriorated for several reasons (Resources, 2005; Al-Simawi, 2010; Al-Simawi, 2011; S. A. Board, 1977).

Finally, it is worth to mention that small projects in upper Tigris generally suffered from an unstable situation and pumping stations were sabotaged, and the instability of the region after 2003 has contributed to an impact on these projects. 


\subsubsection{Ishaqi Irrigation Project}

Ishaqi project was named after the ancient Ishaqi Canal, a canal which has existed since ancient times and extends from Tikrit to the depression of Agarkof, this canal has been deteriorated for a period of time, and then with the prosperity of the city of Samarra, the upper part of it was revived during the reign of the Abbasid caliph Al-Mutassim. The name of the canal was attributed to the Leader of the police of Al-Mutassim, Ishaq bin Ibrahim. The project returned under spotlights again by the proposals of British consultants in the first half of the $20^{\text {th }}$ century, where the thought was to revive the streams in the areas of the right of Tigris River between Baghdad and Samarra. After the construction of Samarra Barrage, Development Board for the first time started studying the project. Later, Bennie \& Partners completing studies and contracts design from (1) to (8) and in 1966 the Spanish company (Spanco) completed the contracts from (9) to (15). Ishaqi project extends from Ishaqi area to Kadhimiyah district, supplies mainly water from Samarra barrage through four concrete openings with dimensions $(2.5 \times 3.5)$ m extending in the form of tunnels of length of $391 \mathrm{~m}$, then discharge into an open canal which is the main canal of the project, canal discharge is $80 \mathrm{~m}^{3} / \mathrm{s}$, this canal is $30 \mathrm{~km}$ long. At the $30 \mathrm{~km}$ distance, the main canal is divided into two branches east and west branches, from which the boundaries of the project into two main sectors, east and west, the main road of Baghdad-Mosul is almost the separation between the two sectors. The eastern canal extends to the left of the main canal, crossing the Baghdad-Mosul road and runs parallel to Tigris River up to $80 \mathrm{~km}$, the maximum discharge is $38 \mathrm{~m}^{3} / \mathrm{s}$, and canal is lined with concrete. The western canal begins at the branching location of the main canal, continued downstream, with maximum discharge of $42 \mathrm{~m}^{3} / \mathrm{s}$, and a distance of $61 \mathrm{~km}$. This canal was lined with rubber layer due to gypsum content of the soil; this was quickly damaged and replaced with concrete. The western canal is fed through siphons which pass down Tharthar-Tigris canal the lands north of Kadhimiyah district.

The net area of the project is 321,000 dunams with 66.4 thousand dunams of orchards, and in addition to the main canals there are 42 branch canals with total length of $665 \mathrm{~km}$, and 1,642 distributary canals with total length of 3,620 km. The irrigation system is paralleled with two main drains, the $60-\mathrm{km}$-long Eastern drain and discharge of $6.35 \mathrm{~m}^{3} / \mathrm{s}$, and the Western drain which is $56 \mathrm{~km}$ long and $6.2 \mathrm{~m}^{3} / \mathrm{s}$ discharge, the two drains made a confluence and starting point of Main Outfall Drain . In addition to the main drains, there are 27 branch drains, a total length of $971 \mathrm{~km}$, and 1,591 collector drains, a total length of 2,524 km. For the right side of Tharthar-Tigris Canal, its territory is draining through the Sabaa Al-Bour, which flows into the MOD.

The project comprises several pumping stations, 13 pumping stations, 5 for irrigation and 8 for drainage, as shown in Table 2 below. 
Table 2: Pumping stations in Ishaqi project (Al-Simawi 2011).

\begin{tabular}{|c|c|c|c|}
\hline Station Name & Type & $\begin{array}{l}\text { No. of pumping units } \\
\text { and capacities }\end{array}$ & Description \\
\hline $\begin{array}{l}\text { Tarmiyah Drainage } \\
\text { (1) }\end{array}$ & Drainage & $\begin{array}{l}4 \text { units, discharge } \\
3.14 \mathrm{~m}^{3} / \mathrm{s} \text { each. }\end{array}$ & $\begin{array}{l}\text { Draining water from the Eastern } \\
\text { drain and Western drain before } \\
\text { connection with MOD. Pumping } \\
\text { drainage water to Tigris River, } \\
\text { where station discharge is } \\
12.5 \mathrm{~m}^{3} / \mathrm{s} \text {. After connecting the } \\
\text { project to MOD, the station's } \\
\text { role was reduced to only the } \\
\text { emergency. }\end{array}$ \\
\hline Taji Drainage (2) & Drainage & $\begin{array}{l}4 \text { units, discharge } \\
1.16 \mathrm{~m}^{3} / \mathrm{s} \text { each. }\end{array}$ & $\begin{array}{l}\text { Pumping drainage water from } \\
\text { TD } 18 \text { to Western Drain.. }\end{array}$ \\
\hline Drainage WD8 & Drainage & $\begin{array}{l}2 \text { metric units, one } \\
\text { half-metric unit. }\end{array}$ & $\begin{array}{l}\text { Pumping drainage water from } \\
\text { WD } 8 \text { to Eastern Drain. }\end{array}$ \\
\hline Ishaqi Drainage (3) & Drainage & 3 metric units. & $\begin{array}{l}\text { Pumping drainage water from } \\
\text { ED33 to Western Drain. }\end{array}$ \\
\hline $\begin{array}{c}\text { Tharthar-Tigris } \\
\text { canal/Sabaa Al- } \\
\text { bour drainage }\end{array}$ & Drainage & 3 metric units. & $\begin{array}{l}\text { Pumping drainage water from } \\
\text { CD6 to Western Drain. }\end{array}$ \\
\hline Ishaqi Drainage & Drainage & 6 metric units. & $\begin{array}{l}\text { Pumping drainage water from } \\
\text { EDN to Eastern Drain. }\end{array}$ \\
\hline Drainage D15 & Drainage & 3 half-metric unit. & $\begin{array}{l}\text { Pumping drainage water from } \\
\text { D15 to Eastern Drain. }\end{array}$ \\
\hline Drainage GD2 & Drainage & 3 metric units. & $\begin{array}{l}\text { Pumping drainage water from } \\
\text { GD2 to Eastern Drain. }\end{array}$ \\
\hline Abayachi & Irrigation & 4 metric units. & $\begin{array}{c}\text { Supporting station to feed } \\
\text { Eastern Ishaqi Canal form } \\
\text { Tigris. }\end{array}$ \\
\hline Irfaiaa & Irrigation & 3 metric units. & $\begin{array}{c}\text { Supporting station to feed } \\
\text { Eastern Ishaqi Canal form } \\
\text { Tigris. }\end{array}$ \\
\hline $\begin{array}{l}\text { Western Ishaqi } \\
\text { irrigation }\end{array}$ & Irrigation & 4 metric units. & $\begin{array}{l}\text { Supporting station to feed } \\
\text { Western Ishaqi Canal form } \\
\text { Tharthar-Tigris canal. }\end{array}$ \\
\hline $\begin{array}{l}34 \text { Eastern Ishaqi } \\
\text { irrigation }\end{array}$ & Irrigation & $\begin{array}{l}2 \text { half- metric units. } \\
\text { One unit of discharge } \\
0.125 \mathrm{~m}^{3} / \mathrm{s} \text {. }\end{array}$ & $\begin{array}{l}\text { Pumping water from Eastern } \\
\text { Ishaqi canal to EN-34. }\end{array}$ \\
\hline Akshashi & Irrigation & 3 metric units. & $\begin{array}{l}\text { Supporting station to Irrigate } \\
\text { lands of Taji and Sabaa Al-Bour } \\
\text { from Tharthar-Tigris canal }\end{array}$ \\
\hline
\end{tabular}


Project implementation has been started since the late 1960s and began at an accelerating progress in the mid-1970s, the main canal opened in the summer of 1979, and the reclamation works continued until 1994.

The project suffers from several problems, the most important of which is the need for comprehensive maintenance works where it was the scene of various security events after 2003, in addition to the lack of sufficient quantities in the tail, where several pumping stations from Tigris River and from Tharthar-Tigris canal were implemented to confront the lack of water.

The location of the project and the human density within the project's territory require a comprehensive rehabilitation process (Resources, 2005; Al-Simawi ,2010; Al-Simawi, 2014; Al-Simawi, 2011; Sousa, 1948).

\subsubsection{Nahrawan Irrigation Project}

The land of Nahrawan project is located within the area of the confluence of Diyala and Tigris Rivers, where project's net area is 161.6 thousand dunams is irrigated by pumping from the left of Diyala River upstream the confluence of Tigris River and from the left of Tigris River downstream Diyala River.

The project was studied by Development Board for the first time within Diyala-Left Kut projects, and was studied by the consultant Bennie and Partners, who submitted the report in 1956 and the consultant Sir M. McDonald, who submitted their report in 1959. The project has been under way since the 1970s. The project includes the following parts:

\subsubsection{Mada'in Irrigation Project}

The project has an area of 51.6 thousand dunams and irrigates from Diyala River and is fed by 3 pumping stations, which are:

Nahrawan pumping station has 4 pumping units with capacity of $2.07 \mathrm{~m}^{3} / \mathrm{s}$, and 7 metric pumping units.

New Qargholia pumping station has 6 metric pumping units.

Old Qargholia pumping station has 4 metric pumping units.

Because of the fact that pumping stations are located in Diyala River and its proximity to the waste discharge of Baghdad's sewers, the pumping of sewage water affects the quality of water. The project canals are not lined, and the network of the drainage is connected to Wehda project.

\subsubsection{Wehda Project}

The project area is 42,000 dunams implemented between 1972 and 1980, where most of the project's canals are lined with concrete. The project is fed by the main Wehda pumping station that lifts water from Tigris River and includes 4 discharge units of $4.86 \mathrm{~m}^{3} / \mathrm{s}$ discharge per each, while the total discharge is $13.5 \mathrm{~m}^{3} / \mathrm{s}$, within the station there are also 8 metric pumping units. There are also two booster stations on branch canals in the project:

The first booster is comprised of 3 pumping units, capacity of each is $4.81 \mathrm{~m}^{3} / \mathrm{s}$ and 
5 metric pumping units.

The first booster is comprised of 3 pumping units, capacity of each is $2.8 \mathrm{~m}^{3} / \mathrm{s}$ and 5 metric pumping units.

Wehda and Mada'in projects share the drainage to Al-Lej main drain in the south of the project and from there to Salman Pak pumping station, which drains water to Tigris River, the capacity of the station is $5 \mathrm{~m}^{3} / \mathrm{s}$ and includes 5 pumping units with capacity of $1.7 \mathrm{~m}^{3} / \mathrm{s}$.

There are also Irrigated land from Diyala and Tigris rivers by private pumps with total discharge of $20.42 \mathrm{~m}^{3} / \mathrm{s}$ (Resources, 2005; Al-Simawi, 2010; Al-Simawi ; 2011; Al-Simawi, 2014; Ministry of Irrigation, 1984).

\subsubsection{Middle-Tigris Project}

One of the most important projects that extends right and left of Tigris River between Baghdad and Kut, it includes important cities, most notably Suwaira. The project was first studied in Diyala-Left Kut projects under Development Board by Sir. M. MacDonald, study had been submitted in 1959. The project was studied again by Swiss consultants and submitted their report in 1983, and then the Iraqi side re-studied the project, the last of which was a study submitted by the National Center for Studies and Designs in 2008.

The total area of the project is 1.66 million dunams, where some fully or in partially medium and small projects were developed inside the command area, namely, Hafriyah project, jut farm, state farm, Kusaiba, Shuhaimiyah and Radhwan Farm, the total area of 440,555 dunams. Excluding city areas and areas for urban development, Tigris River, transportation routes and current and future infrastructure, the remaining area to be developed is 792,323 dunams as net area.

The development of the project in its integrated form includes two alternatives:

1. Irrigation through the construction of the proposed Suwaira Barrage through which the construction of two right and left canals to irrigate the project's land in addition to the boosters within the project.

2. Irrigation by pumping includes the installation of pumps on right and left of the river for watering the land. The latest study by the National Center for Studies and Designs preferred this option after conducting economic analysis and calculations of the cost of construction and operation.

In addition to future areas, the areas currently invested from the main project include the following projects:

\subsubsection{Hafriyah project}

Also called Suwaira project, the project is located on the left of Tigris River in Suwaira district, it has a net area of 133.6 thousand dunams. The project is irrigated by pumping from three main stations that feed the project, which are:

a. Khachiah First station: it is the largest station, includes 6 pumping units of capacity $5.14 \mathrm{~m}^{3} / \mathrm{s}$, the total discharge of $25.7 \mathrm{~m}^{3} / \mathrm{s}$. The station raises the water 
to the $27.35 \mathrm{~km}$ lined canal. On the canal's route there are some booster stations, the first booster is Khaciha second station at the $13.5 \mathrm{~km}$, the second is Khachia third station at the $25.8 \mathrm{~km}$.

b. Zugaitiya pumping station: Water is pumped into Zugaitiya and Douhan Canals, the station has 4 pumping units of $3 \mathrm{~m}^{3} / \mathrm{s}$ capacity, and 6 metric pumping units. Zugaitiya Canal is a $16.5 \mathrm{~km}$-long earth canal with discharge of $4.75 \mathrm{~m}^{3} / \mathrm{s}$. On the route of the canal, at a distance of 12.5 kilometers, there is a booster with 3 quarter-metric pumping units to raise water. Douhan Canal is also earth canal, $12.5 \mathrm{~km}$ long and discharge capacity is $3.45 \mathrm{~m}^{3} / \mathrm{s}$, at the end of the canal there is a booster, which includes two metric pumping units and 3 quarter-metric pumping units.

c. Rubaidha pumping station: it is the last station to feed the $3.65 \mathrm{~km}$ long canal of discharge $4.8 \mathrm{~m}^{3} / \mathrm{s}$. The station comprises 4 pumping units, each of which is $2 \mathrm{~m}^{3} / \mathrm{s}$, seven metric pumping units and a half-metric pumping unit.

In addition to what had been mentioned, the project includes branch and secondary canals counts 15 and a total length of $123 \mathrm{~km}, 92$ distributary canals with a total length of $166 \mathrm{~km}, 796$ water courses with a total length of $812 \mathrm{~km}$. The Drainage network consists of the following:

a. 3709 field drains with and a total length of $15,439 \mathrm{~km}$.

b. 780 collector drains with a total length of $862 \mathrm{~km}$.

c. 87 Secondary and branch drain of a total length $269 \mathrm{~km}$.

d. $34 \mathrm{~km}$ main drain, also called Hallata drain.

e. Hafriah Southern Drainage station includes 4 pumping units with discharge of $0.7 \mathrm{~m}^{3} / \mathrm{s}$ per unit and a metric pumping unit. Station capacity $2 \mathrm{~m}^{3} / \mathrm{s}$.

f. Hallata main drainage station, which pumps water into Tigris River, comprises 4 pumping units with discharge of $2.2 \mathrm{~m}^{3} / \mathrm{s}$ per unit and the total discharge is $6.51 \mathrm{~m}^{3} / \mathrm{s}$.

The project was implemented between 1974 and 1990. Canals, especially the unlined, suffer from the change in the shape of the section, in addition to the interruptions and lack of maintenance of pumping stations, especially the boosters.

\subsubsection{Kusaiba Project}

Kusaiba project is located south of Suwaira and its land is located between Tigris River and MOD. The net area of the project is 45.8 thousand dunams. The land is irrigated by pumping through a pumping station on Tigris River, which includes 7 pumping units with discharge of $2 \mathrm{~m}^{3} / \mathrm{s}$ per unit and a total discharge of the station is $12.6 \mathrm{~m}^{3} / \mathrm{s}$. The station lifts the water to a $10 \mathrm{~km}$ lined main canal, from which the branch and the distributary canals with total length of $143 \mathrm{~km}$ are branching. Drainage network consists of the following:

a. Field drains, a total length of $1720 \mathrm{~km}$. 
b. Collector drains with a total length of $237 \mathrm{~km}$.

c. Secondary and branch drains of a total length $96 \mathrm{~km}$.

d. $19 \mathrm{~km}$ main drain.

e. A Drainage station on the main drain route includes 5 pumping units with different discharges. Station capacity is $2.86 \mathrm{~m}^{3} / \mathrm{s}$.

Main drainage station, which pumps water into MOD, the total discharge is $4.3 \mathrm{~m}^{3} / \mathrm{s}$.

The project was implemented from 1973 to 1984.

\subsubsection{Shuhaimia Project}

The project is located to the south of the Kusaiba project, where it covers a net area of 167,000 dunams. The project is irrigated by pumping from Tigris River through a main pumping station with 4 pumping units, each $4.3 \mathrm{~m}^{3} / \mathrm{s}$, and the total discharge is $13 \mathrm{~m}^{3} / \mathrm{s}$. The station lifts the water to a main lined canal of $20 \mathrm{~km}$ long, as well a network of branch canals of total length $143 \mathrm{~km}$, and a total of $336 \mathrm{~km}$ of distributary canals. This network is paralleled with a drainage network consisting of the following parts:

a. Collector drains with a total length of $317 \mathrm{~km}$.

b. Secondary and branch drains of a total length $127 \mathrm{~km}$.

c. $13.23 \mathrm{~km}$ main drain.

d. Main drainage station, which pumps water into MOD, the total discharge is $3.2 \mathrm{~m}^{3} / \mathrm{s}$.

e. The project was implemented from 1973 to 1984 .

\subsubsection{Dabouni Project}

It is also called Jut Farm, where its purpose was to invest its land to grow jute and linen. The project is located near the city of Daboni, the left of Tigris River, with net area of 54,000 dunams. The project feeds from Tigris River through a main pumping station with $5 \times 3.2 \mathrm{~m}^{3} / \mathrm{s}$ pumping units and the total discharge of $16 \mathrm{~m}^{3} / \mathrm{s}$. The station lifts the water to a $22.5 \mathrm{~km}$ lined main canal. Another booster pump which is also located on the main canal route, it has 4 metric pumping units. The project is fully reclaimed and covered by branch and distributary canals of total length of $78.8 \mathrm{~km}$ and Flumes of total length of $371.7 \mathrm{~km}$. The Drainage network consists of the following:

a. Field drains with a total length of $1760 \mathrm{~km}$.

b. Collector drains with a total length of $338 \mathrm{~km}$.

c. Branch drains of a total length $199.7 \mathrm{~km}$.

d. Main drain, the length is $33.85 \mathrm{~km}$.

e. Main drainage station, which pumps water into Shweicha Lake, the total discharge is $5 \mathrm{~m}^{3} / \mathrm{s}$, where it has 10 metric units. 


\subsubsection{State Farm}

One of the projects linked to Badra-Jassan project, which will be detailed later. State farm is located south of the Dabouni project, where they are separated by the Dabuni-Badra road; the project has a net area of 25,000 dunams. The project feeds from the main canal of the Badra-Jasan project at the distance of $10 \mathrm{~km}$, where the water is supplied by the $3 \mathrm{~m}^{3} / \mathrm{s}$ state farm canal, irrigation network has Flumes with total length of $23.85 \mathrm{~km}$. Project is draining to Shweicha Lake through main drainage pumping station, it includes 4 metric pumping units.

\subsubsection{Rawdhan Farm}

Also called Rawdhan Forest, the farm is located west of the city of Numaniyah and is irrigated through pumping station on the right of Tigris River; station has 5 metric pumping units (Al-Simawi, 2011; Designs, 2008; S. A. Board, 1977).

\subsubsection{Badra-Jassan project}

Badra and Jassan area is well known over time with palm orchards of rare varieties. Badra Valley, which originates from the Iranian side, had suffered since 1930s from water scarcity, which has begun to worsen in this area, especially after the construction of a dam on Kinjan Jam Valley. Iranian side has diverted the course of Badra Valley itself. The basis for the division of water between the two countries is $3 / 5$ for Iraq versus 2/5 for Iran according to the agreement between the two countries, which the Iranian side has not complied with. The area has been home to centuriesold palm orchards, also the people were displaced, and water for the city was supplied by potable tankers. In 1953, General Irrigation Directorate carried out 18 regulators on Badra Valley to cope with the drought, which did not work. Subsequently, in 1961, Planning Board entrusted Sir M. McDonald to study the provision of alternatives to the area of Badra and Mandalay. The company submitted its report, which included the current alternative, in 1969. The project aims to irrigate:

1. Area of 4,075 dunams of orchards with drinking water in Zurbatiya.

2. Area of 11,075 dunams of orchards with drinking water in Badra.

3. Area of 52,000 dunams is being developed for seasonal agriculture with drinking needs in Jassan.

Because of the circumstances of the Iraq-Iran war, the main route and parts of Jassan lands were implemented. The main path, which forms the backbone of the project, includes the following parts:

1. Pumping station No. 1 on Tigris River, it raises water to the main canal. The station has 5 pumping units, each $3.4 \mathrm{~m}^{3} / \mathrm{s}$. The total discharge of the station is $12.5 \mathrm{~m}^{3} / \mathrm{s}$.

2. Main canal heading towards Badra is $65.5 \mathrm{~km}$ long and the canal is partially lined. At the distance of $10 \mathrm{~km}$, a canal is branched from the main canal to the state farm. The canal passes through its route through two siphons: first at the 
intersection of Shweicha Lake and the second at the intersection with Tarsakh Valley.

3. Pumping station number (2) on the canal path. The station has 4 units of $3.4 \mathrm{~m}^{3} / \mathrm{s}$ discharge, and 4 metric pumping units.

4. Pumping station No. 3 on the canal track at the intersection of the canal with Tarsakh Valley, upstream the siphon structure. The station has 4 units of $3.4 \mathrm{~m}^{3} / \mathrm{s}$ discharge, and 4 metric pumping units.

5. Pumping station No. 4 is located at the end of the canal and feeds two routes, one to Jaasan and the other to Badra. The station has 4 units of $3.4 \mathrm{~m}^{3} / \mathrm{s}$ discharge, and 4 metric pumping units .

6. The canal of Jassan, a lined canal of length $13.2 \mathrm{~km}$ and discharge $13.2 \mathrm{~m}^{3} / \mathrm{s}$. The canal irrigates an area of land of about 25,000 dunams and supplies drinking water to Jassan.

7. Badra Pipe route, running from pumping station no. 4 and $17.5 \mathrm{~km}$ long to pump station no. 5.

8. Pumping station No. 5, which raises water through two pipeline routes, one to Badra and the second to Zurbatiya to supply the requirements of irrigating orchards and drinking. The station has 6 pumping units, each with discharge of 0.35 m³ (S. A. Board, 1977; Macdonald, 1971; Al-Simawi, 2010; Al-Simawi, 2011).

\subsubsection{Dalmaj Irrigation Project}

Dalmaj project extends between the cities of Numaniyah and Kut, bordered to the north by Tigris River and to the south by Dalmaj Lake. The project was first studied by Development Board from 1956 to 1959, where the study was carried out by Sir M. MacDonald. The designs and contract documents were prepared between 1960 and 1963 and one of the requirements for the operation of the project was to raise the operating level of Kut Barrage to $18.1 \mathrm{~m}$ a.s.l. The 237,000 dunams area of the project consists of three main canals connected to a network of branch and distributary canals paralleled by 3 drainage networks for each major canal. The main canals from the upstream to the downstream are Huwar Canal, Hussainia Canal and Mazak Canal. These canals are working on gravity feed except for Huwar Canal, which is feed by pumping; knowing that the proposed Suwaira Barrage will provide the gravity feed for this canal. After the water scarcity and the decision to reduce the operating level of the Kut Barrage to $16 \mathrm{~m}$ a.s.l., this led to the cancellation of the Kut Barrage rising role, which was completed in 1967, this consequence the adoption of the project canals on pumping during the periods low level flow. Figure 32 shows a map of Dalmaj Irrigation project. The main canals of the project have the following details:

1. Huwar Canal: A $24.9 \mathrm{~km}$ unlined canal. On the head of the canal is a pumping station with 3 pumping units of $4 \mathrm{~m}^{3} / \mathrm{s}$ discharge, 5 pumping units with $3 \mathrm{~m}^{3} / \mathrm{s}$ 
discharge, and the total discharge is $20 \mathrm{~m}^{3} / \mathrm{s}$.

2. Hussainia Canal: A $30 \mathrm{~km}$ unlined canal, water is drawn from Tigris River through a 3 openings head regulator with maximum discharge of $13.5 \mathrm{~m}^{3} / \mathrm{s}$ and a normal discharge of $8.34 \mathrm{~m}^{3} / \mathrm{s}$. Also, a pumping station with 12 metric pumping units was installed near the head of the canal.

3. Mazak Canal: A $22 \mathrm{~km}$ unlined canal, water is drawn from Tigris River through a two-open head regulator with maximum discharge of $9 \mathrm{~m}^{3} / \mathrm{s}$, and a normal discharge of $7 \mathrm{~m}^{3} / \mathrm{s}$. And a pumping station with eight metric pumping units was installed on the head of the canal. 


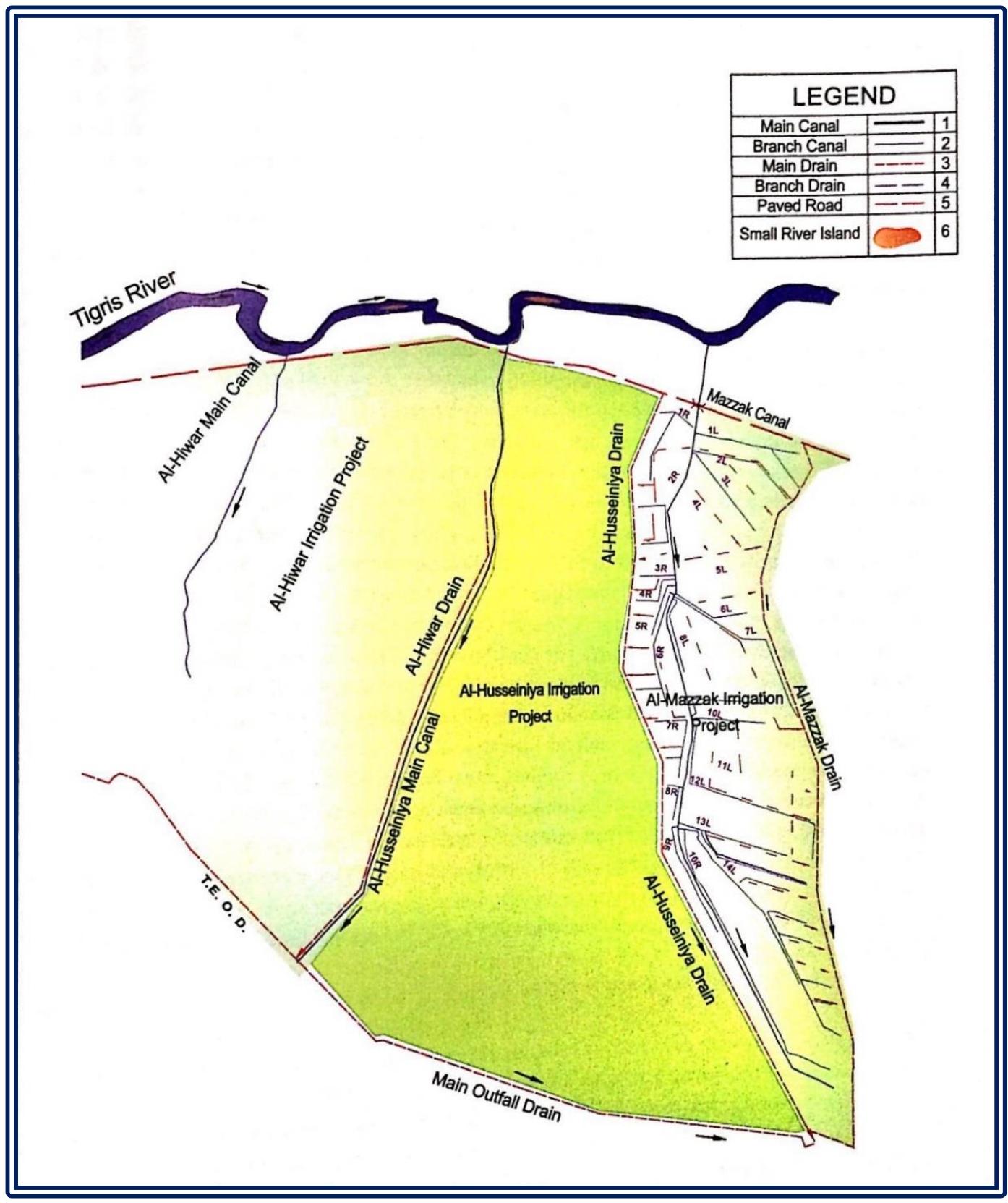

Figure 32: Map of Dalmaj Irrigation Project (MoWR, 2005).

The Drainage network in the project, which drains to Great Gharraf Drain in the south of the project, consists of the following:

1. $90 \mathrm{~km}$ main drains.

2. $392 \mathrm{~km}$ branch drains.

3. $1238 \mathrm{~km}$ collector drains.

4. $8,000 \mathrm{~km}$ field drains. 
The project was reclaimed from 1974 to 1984 by a Pakistani company, where the integrated reclamation works included an area of 153,338 dunams (Al-Simawi, 2011; Al-Simawi, 2014; S. A. Board, 1977; Al-Simawi, 2011).

\subsubsection{Gharraf Canal projects}

Gharraf Canal is the largest and longest branching stream of Tigris River, with length of $178 \mathrm{~km}$ and a maximum discharge of $500 \mathrm{~m}^{3} / \mathrm{s}$. On this canal are several cities, including Muwaffaqiya, Al-Hay, Fajir, Qal'at Sukkar, Rifai and Al-Shatra. Water is provided for irrigation and drinking for these cities ant the territories, as well as providing drinking water through Basra water canal to meet the drinking needs of the cities of Nasiriya, Basra and Suq Al-Shoyukh. The development of Gharraf area has been the interest of all the consultants who worked on the irrigation development in Iraq, the first of which was William Willcocks, who proposed the establishment of Kut Barrage. Later under the Development Board, The American Company TAMS submitted a study on the improvement of irrigation in the region in 1952, followed by CUTHA to study the project and then the company Sir M. McDonald studied the projects of Gharraf, where the projects were divided into two main parts, the lands to the left and named East Gharraf and the lands to the right and named West Gharraf, the company submitted its report in 1968. Then Gersar, a French company, presented a study about the project in 1983, which included the project's drains, which was not presented by M. McDonald's. Later, Swiss consultants have also presented studies on land development downstream of Badaa regulator.

The net area for the project's project is 384,000 dunams for West Gharraf and 475,000 dunams for East Gharraf, development has only made in some sectors in Magheshi and Dawaya, in addition to the construction of regulators, drains and some pumping stations. Dozens of earth canals continuing to supply water from both sides to the non-reclaimed lands of Gharraf area. Gharraf Canal includes the following projects:

\subsubsection{Gharraf Canal Regulators}

On the main canal reach; according to the study submitted by TAMS company in 1952, Polensky and Zöllner form Germany started implementing four regulators, in addition to the construction of dykes on both sides length of $168 \mathrm{~km}$, works completed in 1966, and the details of the works as follows :

a. Regulator No. 1, near Al-Hay city, it has 5 openings and $250 \mathrm{~m}^{3} / \mathrm{s}$ is the normal discharge, the maximum discharge is $500 \mathrm{~m}^{3} / \mathrm{s}$, the regulator includes a navigational lock.

b. Regulator No. 2, near Fajir city, it has 4 openings and $200 \mathrm{~m}^{3} / \mathrm{s}$ is the normal discharge, the maximum discharge is $300 \mathrm{~m}^{3} / \mathrm{s}$, the regulator includes a navigational lock.

c. Regulator No. 3, near Qal'at Sukkar city, it has 4 openings and $120 \mathrm{~m}^{3} / \mathrm{s}$ is the normal discharge, the maximum discharge is $300 \mathrm{~m}^{3} / \mathrm{s}$, the regulator includes a 
navigational lock.

d. Regulator No. 4, downstream of Rifai city, it has 4 openings and $250 \mathrm{~m}^{3} / \mathrm{s}$ is the normal discharge, the maximum discharge is $300 \mathrm{~m}^{3} / \mathrm{s}$, the regulator includes a navigational lock.

\subsubsection{Regulators of Badaa and Al-Shatra}

Two regulators existing at the end of Gharraf Canal, they were created in 1929 from bricks, their details are as follows:

a. Badaa Regulator, which includes 6 openings, 3 of which are of dimensions (2.5 $\mathrm{x} 5.5) \mathrm{m}$ and 3 openings are of dimensions $(3.5 \times 5.5) \mathrm{m}$, normal discharge of the regulator is $25 \mathrm{~m}^{3} / \mathrm{s}$.

b. Al-Shatra Regulator: It is the head regulator of Al-Shatra Canal, it includes 3 openings of dimensions $(2.7 \times 3) \mathrm{m}$ and opening of dimensions $(3 \times 3.5) \mathrm{m}$, normal discharge is $15 \mathrm{~m}^{3} / \mathrm{s}$.

\subsubsection{Magheshi Project}

Part of the West Gharraf Project, the project is located in Fajir area where its water is derived from Regulator No. 3. The project was carried out in the 1970s and consists of only a irrigation network fed by a $17.7 \mathrm{~km}$ main canal of discharge $15 \mathrm{~m}^{3} / \mathrm{s}$.

\subsubsection{Dawaya project}

Dawaiya project is located in the downstream of Gharraf, where it includes earth canals, lands were partially reclaimed. The net area of the project is 135,000 dunams, mostly earth canals, fed mainly by Dawaya canal, which is branched from the upstream of Badaa Regulator. The project was implemented in 1970. Hutaman sector was carried out with and area of 23,000 dunam, as well as Al-Shatra farm, which is area 16,000 dunams, these two sectors are parts of Dawaya project. The project covered by $112 \mathrm{~km}$ of collector drains, $85 \mathrm{~km}$ of branch drains and a $19 \mathrm{~km}$ main drain which discharging to East Gharraf Drain.

\subsubsection{East Gharraf Drain}

The land of Gharraf is surrounded by two main drains, to the east, East Gharraf Drain, and to the west, Great Gharraf Drain and West Gharraf Drain. The $172 \mathrm{~km}$ East Gharraf Drain extends form Dujailah project and connected to MOD, its' discharge is $26 \mathrm{~m}^{3} / \mathrm{s}$. The study and designs of the drain were completed by the French company Gersar in 1986 and work was initiated in the 1990s, where the main pumping station was completed in 1998 and excavations were carried out up to the distance of $65 \mathrm{~km}$ in 2002 . The pumping station was subjected to military sabotage during the occupation of Iraq in 2003. The project was resumed in 2008 and excavations were completed and a pumping station was constructed at the $52 \mathrm{~km}$ distance, comprising 4 pumping units each $6.5 \mathrm{~m}^{3} / \mathrm{s}$ discharge, and the total discharge of the station $19.5 \mathrm{~m}^{3} / \mathrm{s}$. The main pumping station of the drain near MOD 
was completed with funding from international organizations and opened in 2018. It includes 5 pumping units with capacity of $6.5 \mathrm{~m}^{3} / \mathrm{s}$, and a total discharge of the station is $26 \mathrm{~m}^{3} / \mathrm{s}$.

\subsubsection{West Gharraf Drain}

It is $44.75 \mathrm{~km}$ long, the drain discharge water to Great Gharraf Drain through a pumping station with discharge of $17.7 \mathrm{~m}^{3} / \mathrm{s}$. Excavations began in 2007 and are still not yet complete, including the pumping station (Al-Simawi, 2010; S. A. Board, 1977; Al-Simawi, 2011; Al-Simawi, 2014; Al-Simawi, 2011; Macdonald, 1967).

\subsubsection{Dujailah Irrigation Project}

It is one of the important projects in Wasit Governorate on the right of Tigris River, the project feeding as indicated from Kut Barrage. The excavation of Dujailah Canal was initiated in 1937 by General Irrigation Directorate and was completed in 1945, there was distribution of small areas of land to farmers for settlement, and this is one of the major goals of the project. However, the problem of salting soon emerged due to the lack of drainage network. Interest in the project was resumed in 1974 by the supreme board of agriculture. Coincided with the development of relations between Iraq at the time and the Eastern Europe countries, there was a trend to establish a project similar to the Belgrade agricultural industrial complex in Dujailah, to reach a state of agricultural industrial integration between agricultural outputs and livestock outputs and the construction of dairy stations, cow stations, factories and modern cities and orientation towards creating a modern, sophisticated countryside. An agreement was reached with Yugoslavian company Var Belirjoy and the implementation was started of Dujailah Industrial Agricultural Compound, the first phase area was 93,000 dunams, completed in the period from 1973 to 1987. At the beginning of operation, the project management achieved good results of agricultural output, whether wheat cultivation or forage crops, which supplied the cow station that was built. However, the dissolution of the department of Dujailah and the division of its administration into several entities at the end of the 1980s, as well as the decline that occurred in the irrigation sector after 2003, contributed collectively to closing of the cow station and the transformation of the project from its planned objectives, where the role of the project management became based on the distribution of water only to farmers.

In addition to what was reclaimed in the 1970s within what is known as the first phase land, partial development work was carried out to exploit the land of the second and third phases. The net area of the project is 225,000 dunams. After development, Dujailah earth canal is $57 \mathrm{~km}$ long and discharged $42 \mathrm{~m}^{3} / \mathrm{s}$. From Dujailah Canal, there are 13 canals branching called (Shakhat), with total length of $250 \mathrm{~km}$ and is mostly earth canals. The Drainage network includes:

1. Field drains of total length $3875 \mathrm{~km}$.

2. Branch and collector drains of total length $1121 \mathrm{~km}$.

3. Pumping stations for drainage, which are: 
a. Shakha 8 Drainage Station, has 5 pumping units, discharge of each is $1.25 \mathrm{~m}^{3} / \mathrm{s}$, and the total discharge of the station is $6 \mathrm{~m}^{3} / \mathrm{s}$.

b. Shakha 10 Drainage Station, has 3 pumping units, discharge of each is $1.25 \mathrm{~m}^{3} / \mathrm{s}$, and the total discharge of the station is $2.5 \mathrm{~m}^{3} / \mathrm{s}$.

C. Shakha 13 Drainage Station, has 6 pumping units, discharge of each is $2.2 \mathrm{~m}^{3} / \mathrm{s}$, and the total discharge of the station is $11 \mathrm{~m}^{3} / \mathrm{s}$ (Al-Simawi, 2010; S. A. Board, 1977; Al-Simawi, 2014; Al-Simawi, 2011; Al-Hakeem, 2015).

\subsubsection{Lower Tigris Projects}

The projects feed downstream of the Kut Barrage, which is mostly exploited nonreclaimed land on both sides of the river, in addition to the existence of some reclaimed sectors. The first to submit a study on the area was Sir William Wilcocks, who called for the construction of Barrages on Tigris to regulate navigation in the river. Later, the U.S. Company TAMS studied the area and made several proposals that were presented to Development Board. Later, Khairallah Waedi Company and the Polish company Seicop were commissioned in 1960 and submitted their final report in 1968 regarding Amarah project.

The area in lower Tigris includes many large projects, the most important of which is the Great Amarah Project; the implementation is only a small percentage of projects. This area includes the following projects:

\subsubsection{Kut-Butaira Project}

Also called Right Kut-Amarah project, the project includes sectors irrigated by pumping from Tigris. The project consists of 9 sectors 8 sectors on the right, one on the right. A report on the project was prepared by the French company Gersar in 1983. In 2007, sector 4 implementation was started near Sheikh Saad sub-district, which includes an integrated irrigation and drainage network, the area of the sector is 10.8 thousand dunams. It feeds through a pumping station with 3 metric pumping units and a $2 \mathrm{~m}^{3} / \mathrm{s}$ total discharge of the station. The sector's land is being drained by a joint station for sectors (1,2,3 and 4) which has been implemented as part of the project development work, it includes 4 metric pumping units with total discharge of the $3 \mathrm{~m}^{3} / \mathrm{s}$, the station diverts drainage water to the nearby marshes. The development of Sector 4 has been completed and work is under way in Sector No.2.

\subsubsection{Abu Beshot Project}

Abu Beshot project is located in the city of Kumet, right of Tigris River, the net area is 23,000 dunams. The project is served by a $12.55 \mathrm{~km}$ lined main canal that feed from Tigris River through an $8.4 \mathrm{~m}^{3} / \mathrm{s}$ capacity pumping station. The project is fully reclaimed and covered, in addition to the network of lined canals, a collector drains of $36.5 \mathrm{~km}$ long, as well as field drains. Drainage water flowing through a pumping station to the nearby marshes, drainage pumping station and includes 4 pumping units with $1.237 \mathrm{~m}^{3} / \mathrm{s}$ discharge per unit, and the total discharge is $3.71 \mathrm{~m}^{3} / \mathrm{s}$. 


\subsubsection{Nahar Saad Project}

As in the Abu Beshot project, Nahar Saad irrigated by pumping project, the land of the project is located on the left of Tigris River, $37 \mathrm{~km}$ upstream of Amarah Barrage. The net area of the project is 75,000 dunams divided into four stages. Project development was started in 1968, where the project feeds from Nahar Saad pumping station, it includes 6 pumping units with discharge of $3.2 \mathrm{~m}^{3} / \mathrm{s}$, the total discharge of the station $16 \mathrm{~m}^{3} / \mathrm{s}$. The pumping station lifts the water to a $35 \mathrm{~km}$ long main canal of the project, of which $19 \mathrm{~km}$ is lined. The first phase has been reclaimed with and area of 25,000 dunams, in which $528 \mathrm{~km}$ of drains excavated. Other stages are still under development. The drainage was through a pumping station on the main drain which discharge water to the nearby marshes, the total discharge of the station is $3.6 \mathrm{~m}^{3} / \mathrm{s}$, the station has four pumping units with discharge of $1.2 \mathrm{~m}^{3} / \mathrm{s}$.

\subsubsection{Great Amarah Project}

One of the large projects in the country as well as its land is a long-used land. The regulation of irrigation in the Amarah area not only achieves irrigation objectives, but also provides navigational submergence for river navigation. The project was studied by several consultants, the last of which was the Indian consultant and WAPCOS. The development program includes many sectors and details to cover a net area of 588,000 dunams, the irrigation system divided into the following main areas in addition to several small streams branching from Tigris River, namely:

a. Butaira and Eraidh Canals which are branching approximately $15 \mathrm{~km}$ upstream Amarah Barrage, to the right of Tigris.

b. Mesharah and Kahlaa Canals which are branching upstream Amarah Barrage, to the left of Tigris.

c. Great Majar Canal which are branching $25 \mathrm{~km}$ downstream Amarah Barrage, to the right of Tigris.

The development of the lands did not carried out except the sugar cane farm in Majar district, which was dedicated to the production of the sugar factory in the city, the canals and drains were dug for two phases and an area of 47 thousand dunams, later, drainage station Eidawia was built in the project, it includes 11 metric pumping units, the total discharge is $10 \mathrm{~m}^{3} / \mathrm{s}$. Status of the farm now declined. On another hand, in Great Amarah project, only the Barrages and Regulators have been implemented, which are:

a. Butaira and Eraidh Regulators: Two regulators are located on the head of Butaira and Eraidh canals which are branching from the right of Tigris River. These regulators and other regulators and Barrages in Amarah area were designed by the consultant Sekoub and Khairallah Waedi. The two identical regulators were completed in 1979, each consisting of 6 openings of dimensions $(8 \times 8) \mathrm{m}$ and passing a maximum discharge of $700 \mathrm{~m}^{3} / \mathrm{s}$. The normal discharge of Butaira Canal is $80 \mathrm{~m}^{3} / \mathrm{s}$ and the normal discharge of Eraidh Canal is $20 \mathrm{~m}^{3} / \mathrm{s}$. The two regulators are designed with such a large capacity to be 
employed for flood management and the passing of flood waves downstream Kut Barrage to the central marshes due to the limited capacity of Tigris River reach in the city of Amarah

b. Kahlaa Regulator: it is located upstream of Amarah regulator to the left to control flow in Kahlaa Branch, completed in 1977. The regulator includes 6 openings controlled by radial gates with dimensions of $(6 \times 8) \mathrm{m}$. Maximum regulator discharge is $477 \mathrm{~m}^{3} / \mathrm{s}$, and operational discharge is $35 \mathrm{~m}^{3} / \mathrm{s}$.

c. Musharah Regulatro: it is located upstream of Amarah regulator to the left to control flow in Musharah Branch, completed in 1978. The regulator includes 2 openings controlled by radial gates with dimensions of $(2 \times 7) \mathrm{m}$. Maximum regulator discharge is $150 \mathrm{~m}^{3} / \mathrm{s}$, and operational discharge is $50 \mathrm{~m}^{3} / \mathrm{s}$.

d. Amarah Barrage: Construction of the barrage started in 2000 and completed the work in 2004. It consist 6 openings controlled by radial gates of dimensions $(6 \times 8) \mathrm{m}$ to pass discharge of $373 \mathrm{~m}^{3} / \mathrm{s}$. The body of the barrage includes fish ladder and navigational lock with dimensions of $(20 \times 217) \mathrm{m}$.

e. Great Majar Regulator: it is located on the head of Majar branch, at $25 \mathrm{~km}$ downstream of Amarah Barrage to the right of Tigris River, it was completed in 1978 and includes 3 openings with dimensions $(6 \times 9) \mathrm{m}$. The maximum regulator discharge is $170 \mathrm{~m}^{3} / \mathrm{s}$, while the normal discharge reaches $100 \mathrm{~m}^{3} / \mathrm{s}$.

f. Qal'at Saleh barrage: it is located near town of Qal'at Saleh on the Tigris, at a distance of $45 \mathrm{~km}$ downstream Amarah Barrage. It was implemented in 1978 and consists of 3 openings with dimensions of $(6 \times 8) \mathrm{m}$ and controlled by radial gates. The barrage includes fish ladder and navigation lock of dimensions $(16.5 \times 100) \mathrm{m}$.

g. Kassara Barrage: it is located on Tigris, at a distance of $70 \mathrm{~km}$ downstream Amarah Barrage, it was implemented in 1978 and consists of 3 openings with dimensions of $(6 \times 8) \mathrm{m}$. The barrage includes fish ladder and navigation lock of dimensions $(16.5 \times 100) \mathrm{m}$. Barrage is abandoned and needs a rehabilitation to resume to operation (Al-Simawi, 2010; S. A. Board, 1977; Al-Simawi, 2011; Al-Simawi, 2014; Ministry of Irrigation, 2001; Directorate General of Irrigation, 1954).

\subsubsection{Shatt Al-Arab Irrigation Project}

Shatt Al-Arab is a strategic waterway, with length of $197 \mathrm{~km}$ and is fed by the rivers Tigris, Euphrates, Karkha and Karun. The exploitation of these rivers by neighboring countries has unfairly affected the flow of this river, which is located in the vicinity of Mesopotamian river system. Finding a solution to this problem is not only an agricultural expansion, but also an alternative to drinking water and irrigation of orchards in Basra, which were known to be one of the largest palm forests in the world. The reduction in flow consequence the advance salt intrusion from Arabian Gulf in the seasons of low discharges, this is negatively affect the agricultural lands that were irrigated and drained naturally through tidal phenomena, as well as the effect on the intakes of water treatment stations. Some alternatives 
have been studied about Shatt Al-Arab from the beginning, but the circumstances and the fact that Shatt Al-Arab is falling into the realm of political and military conflicts have delayed the implementation of this vital project in its integrated form. The reasons for the deterioration of water quality in the Shatt Al-Arab can be attributed with the different degree of impact to the following:

1. The reduction of flow from the feeding rivers due to the projects of the reservoir in the riparian countries, the most important of which are the Karkha and Karun because they are the closest feeding basins and are the historical nutrients for the formation of the Shatt Al-Arab Delta. The Iranian side has constructed dozens of dams and transformed river courses, most notably Karun River, which has been converted into the Behmanshire Canal, the ancient Karun stream has become a route for disposal of various pollutants. Further, the reservoirs in Turkey have had a negative impact on the water quality of Shatt Al-Arab.

2. Throwing municipal and agricultural waste, degrading water quality in rivers and not completing the connection of main drains to MOD, in addition to the Iranian drains, which discharge to Shatt Al-Arab.

3. Throwing dangerous industrial waste and most importantly what is produced by Abadan refinery on the Iranian side.

4. Marine wrecks, which are estimated of 280 different pieces.

Shatt Al-Arab project includes not only the areas that irrigated from the Shatt AlArab itself, but also those irrigated by Tigris and Euphrates in their lower reaches. At the time of Development Board, TAMS Company had submitted several studies on the development of the project from 1954 to 1958. It was followed by study of Japanese company Nippon Koei, which submitted its report in 1972 and was not accepted by the Ministry of Irrigation at the time. A study of the project was subsequently carried out by Polservice and submitted the report in 1981. This report contains the following key details about the project:

1. Development of 28,000 dunams of Tigris river, land between Kassara and Qurna.

2. Development of 35,000 dunams of Euphrates river, land between Emdaina and Qurna.

3. Development of 240,000 dunams on both sides of Shatt Al-Arab.

4. The construction of a Barrage downstream Garmat Ali.

Ensuring the irrigation of orchards and providing drinking water up to the Fao area. The project did not implement its integrated form for many reasons, the most important of which were the circumstances of the war in the 1980s and the subsequent embargo before 2003. However, parts of the project have been implemented, which are:

\subsubsection{Suwaib Project}

Suwaib Project is located in the city of Qurna on the left side of Tigris River. It is a small project with net area of 19,000 dunams. The project is pumped through a station of 5 pumping units, each with discharge of $0.8 \mathrm{~m}^{3} / \mathrm{s}$. Project's land is also drained through drainage station, which includes 3 pumping units, of discharge 
$0.47 \mathrm{~m}^{3} / \mathrm{s}$ per each.

\subsubsection{Shatt Al-Arab Canal}

The most expensive projects in the water resources sector were implemented after 2003 , where the project included the implementation of only a major canal without branch and distributary canals, drainage network or either soil reclamation works. The canal is $130 \mathrm{~km}$ long and $30 \mathrm{~m}^{3} / \mathrm{s}$ discharge capacity, area has been reduced from 240,000 dunams to 120,000 dunams. The Barrage has not implemented as the recommendations of Polservice, but carried out a pumping station only at the site of Kutaiban comprising 7 pumping units and a total discharge of the station is $30 \mathrm{~m}^{3} / \mathrm{s}$, the station raises the water to an open canal left of Shatt Al-Arab extending for 40 $\mathrm{km}$ and before reaching the border with Iran, it passes through siphon structure to the other side of Shatt Al-Aarb Siphon structure has been carried out by Jacking under Shatt Al-Arab for a length of $1200 \mathrm{~m}$, the discharge of the siphon is $20 \mathrm{~m}^{3} / \mathrm{s}$, it consists of 6 pipes with diameter of one meter and two basins for the inlet and the other for the outlet. At the inlet there is pumping station (PS 2) which raises water to the siphon, and this station consists of two pumping sets, the first set comprises 5 pumps of floating type, these lifts from the canal to the siphon inlet basin and the second set comprises 6 fixed pumping units discharging water through the siphon pipes. After the siphon, the canal continues $90 \mathrm{~km}$ to the nearby of Fao.

\subsubsection{Basra Water Canal}

Formerly known as Wafaa Al-Qa'id Canal. The function of this carrier canal is to provide water treatment plants in the cities of Nasiriya, Souq Al-Shoyukh and Basra with a good quality water from Gharraf Canal. The alternative of this route when displayed in the 1980s was to implement pipes route, but due to the conditions of the embargo, the $238.5 \mathrm{~km}$ open canal option was used. Euphrates Center for Studies and Design had prepared the necessary studies and designs for the canal. Work was initiated in 1992 and work was discontinued at the beginning of 1993. Work resumed on 1/3/1996 and the canal opened on 23/12/1997 at a cost of 9.8 billion IQD. Canal started with a discharge of $21 \mathrm{~m}^{3} / \mathrm{s}$ and continues until it intersects by siphon with MOD at the $49 \mathrm{~km}$ distance of the canal, and then at the distance of $61.5 \mathrm{~km}$ reaches the site of the intersection with Euphrates River near, where water is raised to the siphon structure beneath Euphrates by pumping station (PS 1) which has 24 metric pumping units. The siphon consists of 3 pipes of $1.6 \mathrm{~m}$ diameter, the canal to intersect again with MOD at the $86.1 \mathrm{~km}$ distance. At the distance of 165.5 kilometers there is the pumping station (PS 2), which contains 19 metric pumping units to raise water through pipes passing over the structure of a bridge over MOD, which is 3 pipes with diameter of $1.6 \mathrm{~m}$, followed by the intersection of the canal with the Um Al-Ma'arik Canal at a the $169.35 \mathrm{~km}$ distance, Um Al-Ma'arkik Canal crosses Basra Water Canal through box culvert. The canal reaches at a distance of $227.75 \mathrm{~km}$ to the storage basins (R0), which were built for water storage to avoid the impact of water shortage during a malfunction in the 
operation of the canal, as it initially built a basin with capacity of 750,000 cubic meters, and later the another basin built with capacity of 5 million cubic meters. From the basins, the canal extends to its end at $238.5 \mathrm{~km}$ east of Basra International Airport, where Basra water directorate facilities are. Shapes (53), (54) indicate a chart of the path of the Basra water canal, and storage basins at the end of the canal. Figure 33 shows a general outline of Basra Water Canal, and Figure 34 is a general view of R0 reservoir.

For Basra water canal, $200 \mathrm{~km}$ were lined with concrete, while the rest were lined with good soil due to the gypsum content of the soil. The total discharge of the canal is, as mentioned, $21 \mathrm{~m}^{3} / \mathrm{s}$, including $5 \mathrm{~m}^{3} / \mathrm{s}$ for the city of Nasiriya, $1 \mathrm{~m}^{3} / \mathrm{s}$ for the city of Souq Al-Shouyokh and $15 \mathrm{~m}^{3} / \mathrm{s}$ for the city of Basra. The period after 2003, the canal suffered a lot for several reasons, where due to the incorrect maintenance of parts lined with good soil, this caused leaks and collapses in the sections of the canal, the canal itself was subjected to abuses by many parties. This led the water treatment stations to rely on the withdrawal of water from the Shatt Al-Arab again (Al-Simawi, 2010; Al-Simawi; 2014; Al-Simawi, 2011; Ministry of Irrigation, 2001).

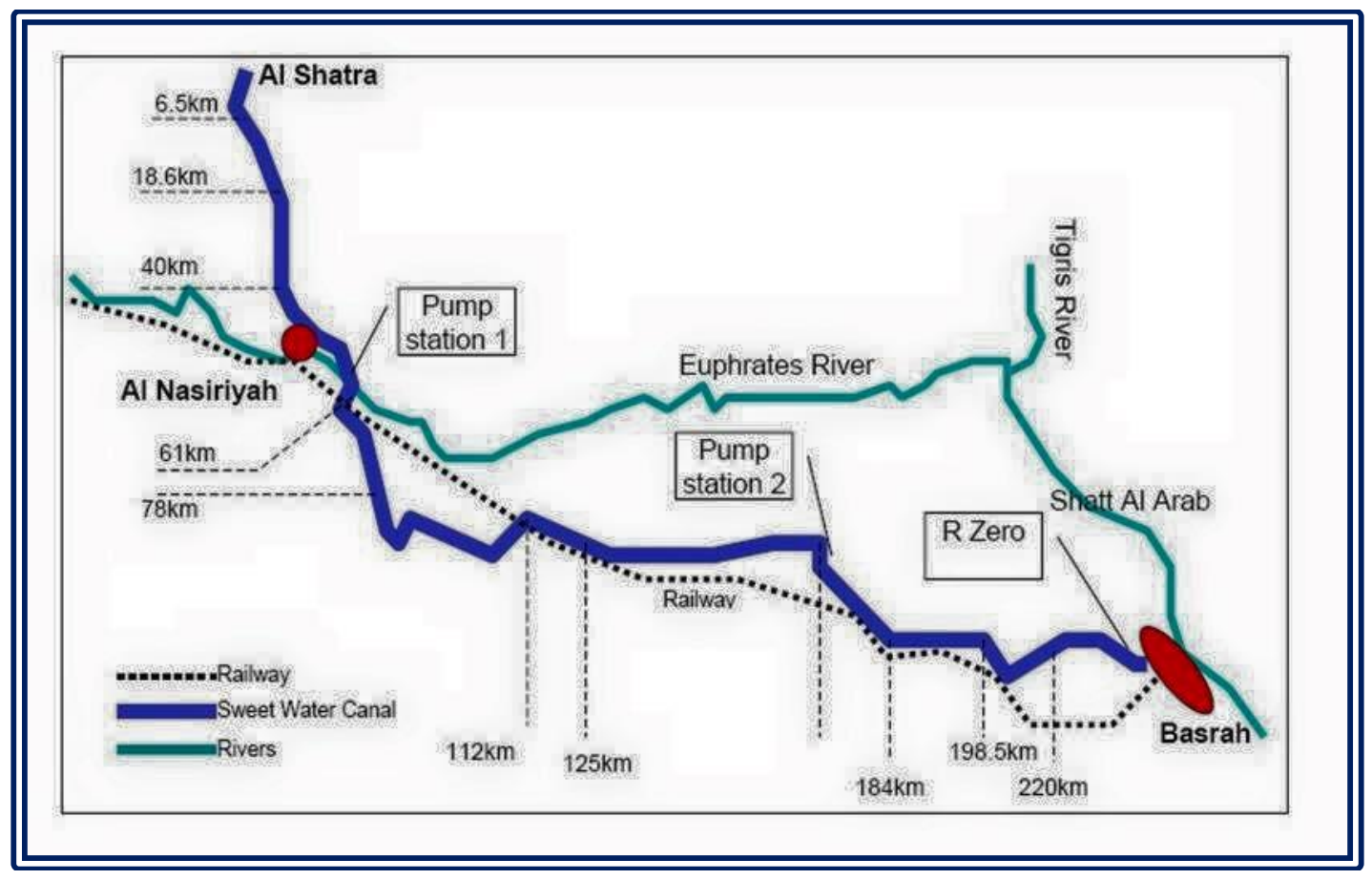

Figure 33: General outline of Basra Water Canal (MoWR n.d.). 


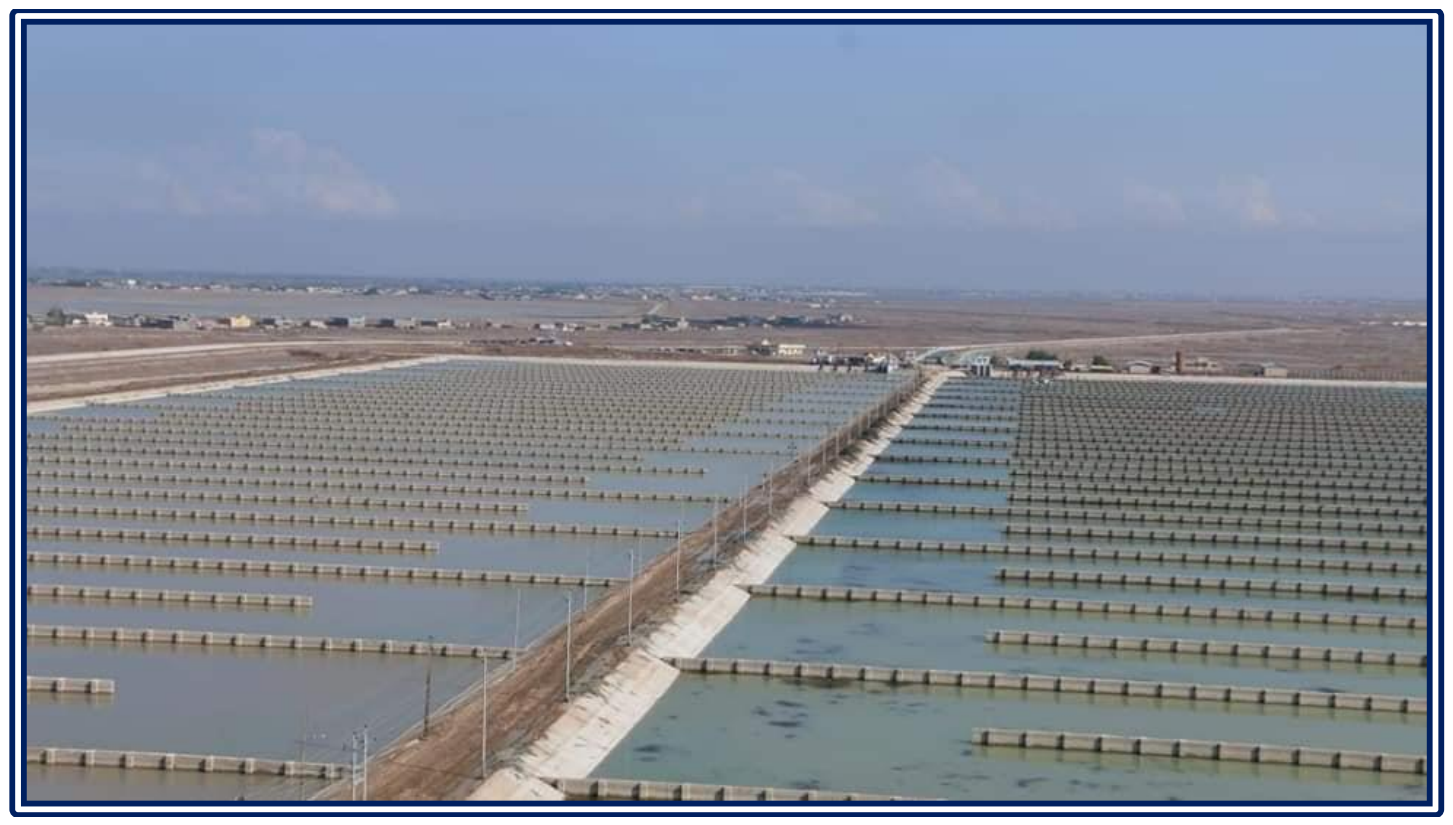

Figure 34: General view of R0 reservoir (MoWR n.d.).

\subsection{Irrigation Projects on Tigris River Tributaries}

Iraq has a good water and land resources in the boundaries of Tigris River tributaries. The first is the small projects in the mountainous area, where the soil and water conditions are very good for agricultural investment. One of the major spots that can be exploited is the boundary of Great Zab River, unfortunately, the incomplete system of storage postpone many important projects. Little Zab and Adhaim Rivers were deployed in one of the largest projects in Iraq, which is Kirkuk-AdhaimHawija Irrigation Project. Finally, Diyala River in term of utilization was divided into middle Diyala, the lands upstream Hemrin Dam, and lower Diyala, the lands downstream Diyala Barrage and feed mainly by the function of this barrages, where on the right side there is Khalis Irrigation Project, while on the right side there is Combined Reach Irrigation Projects.

\subsubsection{Small Projects Irrigation in the Northern Regions}

Small projects in the northern regions are referred to as those projects proposed or implemented in the mountainous areas at the upstream of the tributaries that flow into Tigris River, where a number of flat plains are distributed among the mountains which are used by the people to cultivate various crops and can be exploited for intensive agriculture by adopting complementary irrigation and summer agriculture. These projects, despite the small size of some, represent a very promising opportunity for the cultivation of cash crops due to the suitability of soil and climate as well as the comparatively lower water duty, it is not possible to overcome the fact that instability of security for decades in area was lead to postpone many works and thus missed an important opportunity for development. Although they are called 
small projects, there are some proposed medium-sized projects such as the KhazerGumel project and the Shahrazur project. It is possible to propose more small projects and developing the foothills of the highlands in the form of terraces to achieve more benefits and protect them from erosion.

The flooding of the Dokan and Darbandikhan reservoirs has helped to trigger the interest in looking for opportunities to invest agricultural areas in the northern region. It was necessary to find alternative of agricultural land for the citizens who had been deported from the sites of the two reservoirs in 1954, Development Board entrusted Irrigation General Directorate with foreign consultants to study the possibilities of small irrigation projects in the northern regions. The study was then divided into two regions, the first including the lands of the Khabur basin and Great $\mathrm{Zab}$ basin and the second including the lands of the Lesser Zab basin and Diyala Basin. Later, in 1955, Development Board had selected Kulijian to study irrigation possibilities in three regions:

1. Shewarish-Gewer,

2. Khazir-Gumel,

3. Zakho.

Among the companies that have also contributed to the study of these projects in later stages is the Polish company Polservice, which submitted its report in 1980 after conducting a series of investigations and studies for a number of projects, below some of implemented small irrigation projects in the northern regions:

\subsubsection{Duhok Irrigation Project}

The project was carried out after construction of Duhok Dam, the project was studied in its final form by the Bulgarian company Akrocomplect and was carried out by Pakistani and Emirates companies, it was completed in 1988. The project is located in Duhok plains and Sumail district, where it is located north of the DuhokMosul road and Duhok-Sumail road. The project is fed through an irrigation tunnel that draws water from the Duhok Dam reservoir, which is $2035 \mathrm{~m}$ long and $2 \mathrm{~m}$ in diameter. The water runs after the tunnel in a $14.65 \mathrm{~km}$ main open canal and discharge of $8.2 \mathrm{~m}^{3} / \mathrm{s}$. The main canal has 27 irrigation off-take, the irrigation systems as following:

a. 5600 dunam irrigated by gravity.

b. 7300 dunam irrigated by sprinklers.

c. 2100 dunam irrigated by trickles.

Of the abovementioned areas, the net area of the project is 12.6 thousand dunams. The project does not include drainage network and some of the area were exploited for urban expansion, and there will be more in the future.

\subsubsection{Sangasar project}

One of the projects implemented to resettle those who have been deported due to Dokan reservoir flooding. The project consists of a small dam located on Karin tributary, which flows north of the lake. The project area is 8,300 dunams. It 
includes a main rectangular canal distributes water to users.

\subsubsection{Ranya-Sarchawa Project}

The land of the Ranya-Sarchawa project is located in Ranya district and in the surrounding plains in the north-eastern part of Dokan Dam Lake. The project was studied by the Polish consultant Polservice in 1980. The project is divided into an eastern part, fed by Ranya springs with discharge of $0.5-1 \mathrm{~m}^{3} / \mathrm{s}$, a northern part which feeds from the Sarchawa springs with discharge of $4-5 \mathrm{~m}^{3} / \mathrm{s}$ and a western part that feeds from the Kani-Maran springs and its discharge $0.4-0.5 \mathrm{~m}^{3} / \mathrm{s}$. The net area of the project is approximately 40,000 dunams, and according to the consultant's study, the project plans to include irrigation, sprinklers and drip irrigation.

After 2003, interest in the implementation of the Ranya Sarchawa project increased, and work has been initiated to develop the northern part, which is based on Springs of Sarchawa, the estimated total area is approximately 18,000 dunams. In 2011, the development of this sector was completed, a dam was built around spring which has a length of $520 \mathrm{~m}$ and height of $10 \mathrm{~m}$, reservoir capacity is 350,000 cubic meter. Spring normal discharge is $4 \mathrm{~m}^{3} / \mathrm{s}$. A spillway also included with discharge of 58 $\mathrm{m}^{3} / \mathrm{s}$, also a diversion conduit of $5 \times 8 \mathrm{~m}$ dimension and 2 head regulators with discharge of $2.4 \mathrm{~m}^{3} / \mathrm{s}$. Concrete-lined Canals have carried out, 4 canals of total lengths $13 \mathrm{~km}$.

\subsubsection{Shahrizor Irrigation Project}

The Plains of Shahrizor are located to the southeast of Sulaymaniyah city and are surrounded by the Mountains of Qardagh, Azmar, Surein, and Reservoir of Darbandikhan Dam. The plains include important cities, most notably Halabja, Sayed Sadiq, Halabja Al-Jadida and others. Although not fully developed, the project is an important site because of its proximity to major cities and the presence of large numbers of people in the region. Polish consultant Polservice prepared a study about the project in 1981 and provided alternatives to the exploitation of the project's land. The first alternative includes the investment of 93,700 dunams as a net area and the second alternative with net area of 56,500 dunams, which was approved by the Ministry of Irrigation later due to the scarcity of water in Diyala River. Irrigation system based on developing springs, from which the water to be conveyed to the nearby lands, the irrigated area is currently estimated at 56,000 dunams. The spring collections include the following springs groups:

a. Bustana Sur group.

b. Meyuan Springs and Chami Mewan group.

c. Sarawa group.

d. Khurmal and Balakh group.

e. Zalam group.

f. Hassar Qurniah group. 


\subsubsection{Kalar Project}

The project is located on the left side of Diyala River, where a pumping station on

Diyala River of a capacity $2.6 \mathrm{~m}^{3} / \mathrm{s}$. The station discharge to an $8.7 \mathrm{~km}$ lined main canal. This canal was lined up and many structure carried out between 2004 and 2008, with net area of 6,000 dunams (Sousa and Sevian, 1965; Al-Simawi, 2010; Al-Simawi 2008).

\subsubsection{Eski-Kalak project}

Interest in Eski-Kalak project began from the time of the Development Board, where the U.S. Company Koljian was tasked with surveys, detailed study and design and completed its work in 1956. In the early 1970s, coincided with the establishment of a sugar factory in Mosul, the implementation initiated to supply sugar beets. The project draws its water from Great Zab River, Head Regulator with three openings which feeds a $26 \mathrm{~km}$ main canal and a $9.5 \mathrm{~m}^{3} / \mathrm{s}$ discharge, this canal feeds the first phase of the project, which is around 20,000 dunams, there are branch canals of total lengths $110 \mathrm{~km}$. The second stage is irrigated by pumping through a pumping station at the $16 \mathrm{~km}$ station of the main canal, feeding two canals, first canal no. 5, which is $25 \mathrm{~km}$ long and feeds an area of 11,000 dunams, and canal no. 10, which is $26 \mathrm{~km}$ long and irrigates an area of 12.5 thousand dunams. The total length of the branch canals within the second phase is $73 \mathrm{~km}$ and is currently stopped due to the malfunctioning of the pumping station because the lack of maintenance. All canals are earth canals except $3 \mathrm{~km}$ at the beginning of the main canal are lined with concrete. The first phase was completed in 1971, and the second phase was completed in 1981 (S. A. Board, 1977; Al-Simawi, 2010; Sousa, 1966).

\subsubsection{Kirkuk-Adhaim-Hawija Irrigation Project}

Although the three projects are widespread within Kirkuk, Salah al-Din and Diyala governorates, the operation of these projects in their status are carried out by various departments. However, the nature of the project and the hydraulic operation of infrastructures of the project in addition to studies and designs. Thus, can be considered one large project, which is one of the most important projects of the country, where the total area is more than one million dunams. The lands of project are located on the left of Little Zab River, it starts from Dibis district to Kafri district, where the project is supplying from the far downstream discharges to Diyala River, the project is bordered to the south by Zeghaiton Valley, which is one of the tributaries of Adhaim River, in addition to the lands of Left and Right of Adhaim River downstream of Adhaim Dam.

In addition to the project is the feeding and expansion of the old Hawija project, where Hawija project was fed in earlier periods by Fell and Abbasi rivers. The development of the Hawija project was initiated by the development of the Hawija canal in 1936 and opened in 1940, Hawija Canal feeds from Little Zab River, the intake at the site of Batma, a head regulator controls the discharges of a single opening structure, which dimensions is $1.5 \times 5 \mathrm{~m}$ and discharge is $20 \mathrm{~m}^{3} / \mathrm{s}$. Hawija 
canal had suffered and continues to suffer from insufficient water levels during low seasons of Little Zab River. After the construction of Dokan Dam and the thinking of investing the lands to the left of Little Zab, Bennie \& Partners commissioned by Development Board began to study the project in 1957, then the French company Sogeria carried out detailed studies of the project, designs and contracting documents during the period between 1966 and 1972. According to the preliminary studies of the project, the total area is 1,448,000 dunams. Figure 35 shows a map of the Kirkuk irrigation project. While the size of the development areas within the project are as follows:

1. 764,000 dunams to be irrigated within the Kirkuk irrigation project.

2. 482,000 dunams to be irrigated on the left and right of Adhaim River, downstream Adhaim Dam.

3. 172,000 dunams of Hawija project.

4. 30,000 dunams is expansion of the Hawija irrigation project.

The project consists of three stages as well Hawija irrigation project, details as following:

\subsubsection{Phase 1}

This phase includes parts fed by the main canal of the project to Khardra Valley in Taza district. The main canal in this part is $67 \mathrm{~km}$ of which $37 \mathrm{~km}$ is considered feeder canal from the origin head regulator till Multaqa sub-district, of this distance $25 \mathrm{~km}$ lined with concrete and rubber layers and a part of a length of $12 \mathrm{~km}$ was lined with rubber layers and coarse gravel, rubber layers were used due to nature of gypsum existing in the area. Followed that, a distance of $30 \mathrm{~km}$ lined with good soil and at the end of the canal at this part, there are syphon structure to 


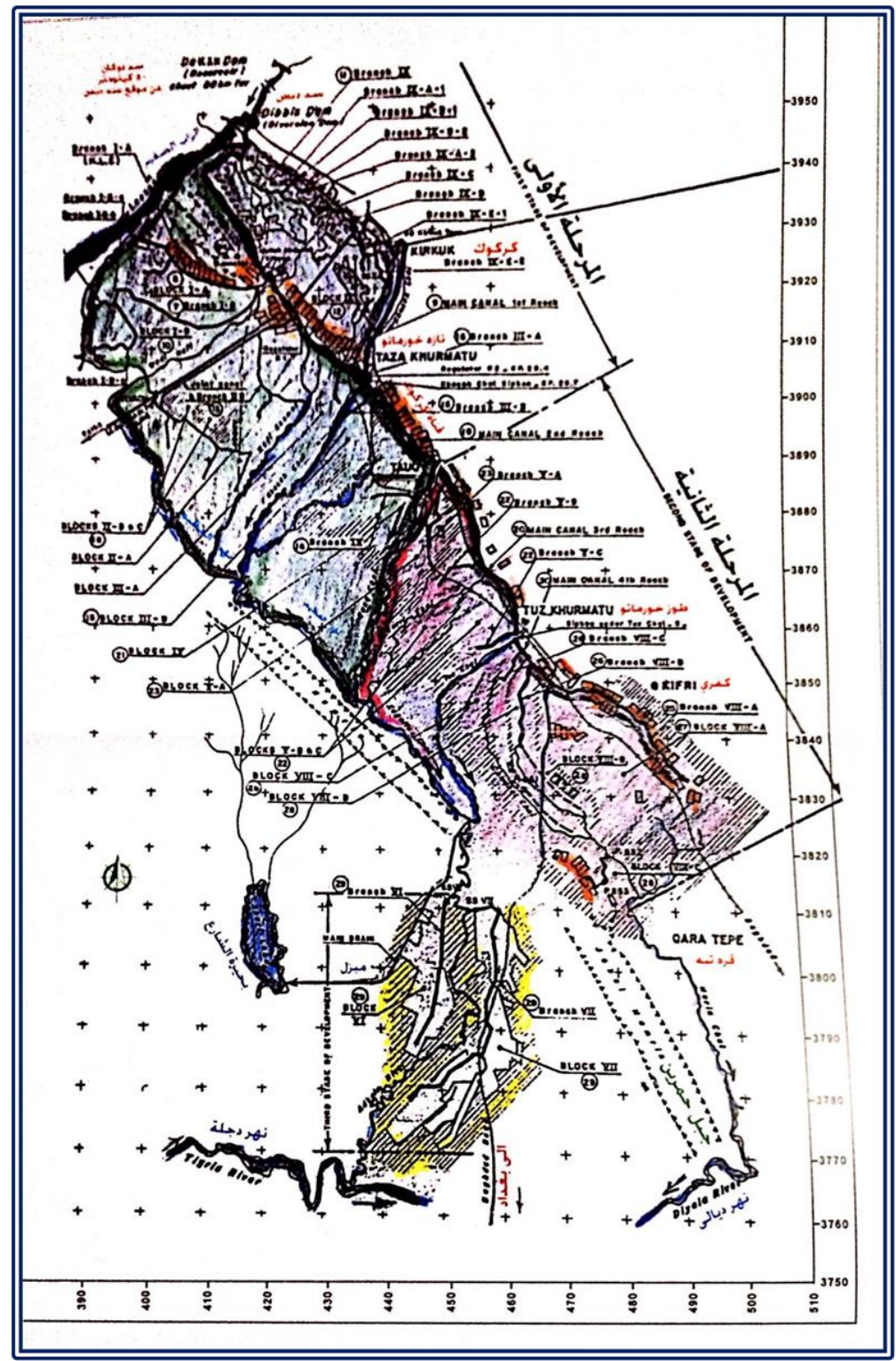

Figure 35: Map of Kirkuk irrigation project (MoWR 2005).

By pass water under Khasa Valley, this syphon followed by another syphon under Khardra Valley. This phase includes the following:

1. Basin No. 9: The first basin in the project, where at the distance of $8 \mathrm{~km}$ from the main canal, the basin feed by Qadisiyah pumping station, which is the main station of this basin, has 14 pumping units a total discharge of $28 \mathrm{~m}^{3} / \mathrm{s}$. The station divert water through pipes of approximately $1.8 \mathrm{~km}$ length, which flow into a stilling basin of the main canal of Basin 9, this canal covers the lands between Kirkuk city and Dibis city and is surrounded by high lands on both sides. Also on the main canal path, the pumping station (FAO), which comprises 
8 pumping units and its total discharge $20 \mathrm{~m}^{3} / \mathrm{s}$, the canal continues to the nearby of Kirkuk city, where it is located at the end the second pumping station (Shaimaa) which includes 5 pumping units of total discharge $3.25 \mathrm{~m}^{3} / \mathrm{s}$. This station provides water for Kirkuk municipal needs. The lands of basin No. 9 are the only ones which are irrigated by pumping as it is high compared to the rest of the project. This basin includes 10,000 dunams irrigated by gravity, and 20,000 dunams irrigated by pumping.

2. Basin No. 1: At the $37 \mathrm{~km}$ distance from the main canal near Multaqa area, the main canal of Basin No. 1 branched from the right, the land of Basin No. 1 is located between Little Zab River and Naft Valley, and Bitira hills in the north. At the end of the main canal of this basin, the feeder canal of the Feeder canal Hawija irrigation project branch. The irrigated area in this basin is 104.5,000 dunams and the area irrigated by sprinklers is 30,000 dunams.

3. Basin No. 2: In the area between Naft Valley and Abu Shihma Valley is the land of Basin No. 2, which has an area of irrigated land of 84.5 thousand dunams. The main canal of the project is a joint canal which feeds Basin No. 2 as well as the eastern parts of Hawija irrigation project.

Basin No. 3: It is the land between Abu Shihma Valley and Khardra Valley. Basin area is 41,000 dunams irrigated by gravity, and 10,000 dunams irrigated by sprinklers.

\subsubsection{Phase 2}

Land of this phase extends from Khardra Valley to Narin Valley in Kafry district, the main canal in this part is $63.3 \mathrm{~km}$ long and passes through several siphons, including Tawook Chai at Tawook Chai Valley at the distance of $87 \mathrm{~km}$ from the main station, which was planned to establish a hydropower station on it, as well as the siphon of Tuz which built in 200, the length of it is $1320 \mathrm{~m}$, it includes two openings with dimensions $(3 \times 3.75 \mathrm{~m})$ and a total discharge of $51 \mathrm{~m}^{3} / \mathrm{s}$. Within this phase are the following basins:

1. Basin No. 4: The land between Khardra Valley and Tawook Chai Valley, the area of 65,000 dunams irrigated by gravity.

2. Basin No. 5: The land between Tawook Chai Valley and Tuz Chai Valley, the area of 99,000 dunams, is partially irrigated and partially implemented.

3. Basin No. 8: The land between Tuz Chai Valley and Narin Valley, the area of 150,000 dunams partially implemented, from this stage the extension of main canal continues to supply Narin Valley with water, which flows into Diyala River to support discharges.

The distribution canals in Kirkuk irrigation project are designed from the type of closed pipes, which are mostly asbestos pipes and the outlets of these pipes are in the form Hydrants, this configuration is called the California System, while the water course canals are pre-cast suspended flumes sitting of pre-casted stands. These infrastructures were largely implemented in the first phase. The second phase, many of which were implemented after the economic blockade, has been shifted 
towards open canals adaption. The two-stage pipeline lengths are $600 \mathrm{~km}$, while the flumes have a total length of $2,250 \mathrm{~km}$.

\subsubsection{Phase 3}

The land located at the downstream of Adhaim Dam, on both sides of Adhaim River, it consists of the following parts:

1. Adhaim Weir: It is located $4 \mathrm{~km}$ downstream from Adhaim Dam to ensure the operational levels of basins 6 and 7 of the third phase, the site of the weir has been selected by the consultant Benniee \& Partners, and was designed by Faw Office of Engineering Consultancy and implemented by the General Company for Industrial Crops of the Ministry of Agriculture in 2001. The weir is $137.2 \mathrm{~m}$ long and $5.5 \mathrm{~m}$ high at an average of $89.5 \mathrm{~m}$ a.s.1. Normal discharge is $1,150 \mathrm{~m}^{3} / \mathrm{s}$ and a maximum discharge is $3,500 \mathrm{~m}^{3} / \mathrm{s}$. There is also a saddle dam functioning as emergency spillway. The weir has 2 gates for sediment removal, with a total discharge of $50 \mathrm{~m}^{3} / \mathrm{s}$.

2. Basin No. 6: It lies to the right of Adhaim River, downstream of Adhaim Dam, where these lands are fed through the head regulator which is right of the Adhaim Weir, the regulator discharge the water to a $44.1 \mathrm{~km}$ canal which feeds the project, its discharge is $43.3 \mathrm{~m}^{3} / \mathrm{s}$, form the canal length about $12.6 \mathrm{~km}$ is not lined. The net area to be irrigated within this basin is 129,000 dunams and is currently partially implemented. The development and management of these lands has been entrusted to the General Industrial Crops Company, which is slowing down. The land of Basin No. 6 drainage is discharging toward Shari Lake.

3. Basin No. 7: which is on the opposite side of Basin No. 6. Its land is among the future projects, with an area of 101,000 dunams.

\subsubsection{Hawija Irrigation Project}

As mentioned earlier, Hawija irrigation project is one of the old existing projects. The project area in full development will be 137,000 dunams. From the beginning, the project feeds from Little Zab River through head regulator near the Batma site, and the water passes to a $28.6 \mathrm{~km}$ main canal, from which, there are several branches branch:

1. Northern branch: Branching at the $4.2 \mathrm{~km}$ distance of the main canal to feed the basins $(1,2,4)$. It is preceded by basins 3 and 10, which draw water directly from the main canal.

2. Western Branch: Branching at the end of the main canal and feeding the basins $[5,6,7,8,9,11]$.

3. Southern Branch: Branching at the end of the main canal and feeding the basins $[15,16,17,18,19,20]$.

4. Eastern Branch: The largest branch where it branches at the end of the main canal and feeds the basins [21 to 37].

The drainage system of the project is the natural drainage to the ancient rivers, 
namely Abbasi and Fell Rivers, and as there is no control on water levels downstream the head regulator. The project's feeding and expansion have been studied and expanded as part of the Kirkuk irrigation project. After examining several alternatives, the option of feeding the project was reached through two routes, the first from the end of Canal A1 in Basin 1, which feeds the main canal with its branches except parts of the eastern branch. The second feeding route is the mentioned Joint Canal, which feeds parts of the eastern branch after the $17 \mathrm{~km}$ distance, to irrigate the basins [25 to 37].

The project was developed in the 1940s, reclamation works were initiated again and the first stages of modern development opened in 2001 and continued until 2003. Due to security status and many other factors, the development of the southern parts of the project stalled after 2003. As a result of the water scarcity and the rotation of canals operation, the canal which are fed from basins 1 and 2 of the Kirkuk irrigation project have been included, this reflecting negatively on the status of Hawija project and highlighting the problem of water scarcity once again.

At the end of the review of Kirkuk irrigation project, this giant project, which was hoped to cover an important part of the country's need for food and the operation of labor, provides a model of the reasons which led to the delay in the completion of such important projects (Al-Simawi, 2010; Al-Simawi, 2011; Al-Simawi, 2014; Ministry of Irrigation, 2001; Directorate General of Irrigation, 1954; Sousa; 1966; Partners, 1962).

\subsubsection{Middle-Diyala projects}

For the land which feeds from Diyala River downstream of Darbandikhan Dam to Hemrin Dam, it is divided into the lands of Upper Diyala and Middle Diyala. Most of what is exploited from these projects is within a geographically middle-lying area, which is mainly exploited and does not involve full reclamation. They are as follows:

\subsubsection{Balajo- Khanaqin Project}

An old existing project that feed from Wand River, and as the Iranian side cut off water from the river, in 1960 the General Irrigation Directorate implemented the project to supply Balajo Canal, which feeds from Diyala River to revive Wand River. The project covers an area of 80,000 dunams, which is irrigated from Balajo Canal and Wand River, and lands of Dakat project, which is irrigated directly from Diyala River. The head regulator of the project is on the left of Diyala River, discharging to the $39.5 \mathrm{~km}$ long main canal which is the same Balajo Canal; the discharge is $10 \mathrm{~m}^{3} / \mathrm{s}$. The canal was lined with concrete, for the land which feeds from Wand River itself, on the right side, land is irrigated through Haj Qara and Qulai canals, while the left side irrigates land through Alyawah and Khanaqin canals. 


\subsubsection{Sheikh Langar Project}

The land of the project is located in the plains between Kafri district and Diyala River. The total project area is 34,280 dunams divided into two phases, the first within area of 18,350 dunams of water and is currently exploited where a main lined canal of $25 \mathrm{~km}$ and branch canals with total length of $38 \mathrm{~km}$ to cover this stage, the second stage is a future stage, planned to be irrigated by pumping and sprinklers, the area of this stage is 15,750 dunams.

\subsubsection{Qara Tabeh Project}

An exploited irrigation project located on the right of Diyala River, the project's land is bordered by Diyala River and The Hemrin Dam Lake. The project area as planned after the development is 104,000 dunams, while the current irrigated area is 71,000 dunams. All canals of the project are earth canals, within the command area of the project, there are the following canals:

a. Salam Canal of discharge $2 \mathrm{~m}^{3} / \mathrm{s}$.

b. Qara Tabeh Canal of discharge $5.27 \mathrm{~m}^{3} / \mathrm{s}$.

c. Kashkul Canal of discharge $2.55 \mathrm{~m}^{3} / \mathrm{s}$.

d. Qara Bulagh canal with discharge of $1 \mathrm{~m}^{3} / \mathrm{s}$.

e. Mihnat Abad Canal with $1 \mathrm{~m}^{3} / \mathrm{s}$ discharge.

f. f. Other small canals feed from Diyala River with total discharge of $4 \mathrm{~m}^{3} / \mathrm{s}$.

\subsubsection{Saadiya Project}

The land in Saadiya area is on the left of Diyala River and feeds from Saadiya earth canal, which is branching from Diyala River in Jalwlaa district; the length of the canal reaches $22 \mathrm{~km}$ and its discharge $2 \mathrm{~m}^{3} / \mathrm{s}$. The project is part of the future development plans to increase irrigation area through pumping. (Resources; 2005; Al-Simawi, 2014; Al-Simawi, 2011; S. A. Board, 1977; Sousa and Sevian, 1965; Hassun and Al-Haialy, 2015).

\subsubsection{Khalis Irrigation Project}

Khalis project is one of the strategic and important projects where the land is covered the right agricultural area of the lower reach of Diyala River, it is fed from the upstream of Diyala Barrage, where Khalis head regulator are. Some of the lands under project command area are irrigated from Tigris River by pumping. Khalis project is divided into two projects, Upper Khalis and Lower Khalis. As a part of its study of Diyala River utilization, Sir M. MacDonald studied the project and reported from 1957 to 1960, the first implementation was initiated in 1967 and continued until 1985.The main Khalis canal is $105 \mathrm{~km}$ long, the upstream part of it is $53 \mathrm{~km}$ unlined, and the rest is lined with concrete. The highest discharge of the canal is $96 \mathrm{~m}^{3} / \mathrm{s}$, and its normal discharge is $65 \mathrm{~m}^{3} / \mathrm{s}$. In addition to the main canal, Khalis irrigation project includes the following:

1. Secondary canals of $169 \mathrm{~km}, 91 \mathrm{~km}$ earth canals, $78 \mathrm{~km}$ lined.

2. Branch canals with length of $538 \mathrm{~km}, 224 \mathrm{~km}$ earth canals, 314 kilometers lined. 
3. Distributary canals of length $1198 \mathrm{~km}, 1188 \mathrm{~km}$ earth canals, 810 kilometers lined.

The project also covered by a drainage network, where the water of the drainage is pumped or drained into Diyala River or Tigris River. The drainage network consisting the below details:

1. $258 \mathrm{~km}$ main drains.

2. $552 \mathrm{~km}$ secondary drains.

3. $2286 \mathrm{~km}$ collector drains.

4. $6668 \mathrm{~km}$ field drains.

Khalis is a pioneering project, including the use of sprinkler and drip irrigation techniques, as well as the use of self-propelled gates of Avis and Avio. Irrigation Automation system was also adopted in the lower Khalis project, where the control center in Ghalbiya area in Diyala governorate is controlling the opening and closing of the gates, due to man error in 1991 the system was damaged and stopped.

The net area of the Upper Khalis project is 215,837 dunams, of which 13,960 dunams of orchards are. The net area of Lowe Khalis is 230,000 dunams, of which 10,000 dunams of orchards. Khalis project includes a number of major pumping stations:

1. Khalis pumping station: the largest pumping station in the project has been implemented in a record time from 25/3/2000 to 1/6/2000 to cope with the scarcity of water in Lower Khalis, where the station has 42 metric pumping units, as well as $16 \mathrm{~km}$ lined canal to convey water to Lower Khalis, the maximum discharge is $50 \mathrm{~m}^{3} / \mathrm{s}$.

2. Jizani pumping station: supporting station to irrigate some land and provide Khalis canal with water drawn from Tigris River, the station includes 12 halfmetric pumping units, 4 metric pumping units, the capacity is $6 \mathrm{~m}^{3} / \mathrm{s}$.

3. Rashidiya Pumping Station: the station lifts water from Tigris River to irrigate land near the river; discharge is $2.5 \mathrm{~m}^{3} / \mathrm{s}$. It has 6 different pumping units with different capacities.

4. South Rashidiya Station: the station lifts water from Tigris River to irrigate land near the river; discharge is $2 \mathrm{~m}^{3} / \mathrm{s}$. It has 11 different pumping units with different capacities.

5. Dawoodi Drainage Station: This station drains the water of the Dawoodi Drain into Tigris River; it contains 6 metric pumping units.

6. Drainage DD2 station: This station discharges DD2 drain into Tigris River and includes two half-metric pumping units.

7. KSD Drainage station: This statin is on KSD drain and contains 6 metric pumping units.

8. KSD 6 Drainage station: This statin is on KSD 6 drain and includes a metric pumping unit (Al-Simawi, 2010; Al-Simawi, 2011; Al-Simawi, 2014; Ministry of Irrigation, 2001). 


\subsubsection{Combined Reach projects}

These are some projects have long been fed by from the left of Diyala River from a number of ancient streams, including orchards, which included the area studied by the consultant Sir M. MacDonald, as in Khalis project within the projects of lower Diyala. After the completion of Diyala Barrage, these projects were organized to feed the water from the Combined Reach head regulator and the Combined Reach Canal, the projects in this section includes the following parts:

\subsubsection{Combined Reach Canal}

After the Combined Reach head regulator at Diyala Barrage, the water is discharge to the $14.6 \mathrm{~km}$ long Combined Reach canal, which has a capacity of $129 \mathrm{~m}^{3} / \mathrm{s}$. It feeds the projects of Mandali, Ruze, Muqdadiyah, Mahrut and Saryah. Along this canal there are several regulators, the most important of which is the $3.5 \mathrm{~km}$ regulator, which is a cross regulator with 6 openings of dimensions $(2.5 \times 4) \mathrm{m}$ and a maximum discharge of $117.8 \mathrm{~m}^{3} / \mathrm{s}$. There are also some of head regulators feed from Combined Reach canal, the most important of which are:

a. Mandaly head regulator: It is at the $3.5 \mathrm{~km}$ distance, on the left of Combined Reach canal, it has two openings with dimensions (1.75 x 3.5) $\mathrm{m}$ and discharge of $6.9 \mathrm{~m}^{3} / \mathrm{s}$.

b. Ruze head regulator: It is at the $3.5 \mathrm{~km}$ distance, on the left of Combined Reach canal, it has 4 openings with dimensions (2x 4) $\mathrm{m}$ and discharge of $47.5 \mathrm{~m}^{3} / \mathrm{s}$.

c. Mahrut head regulator: It is at the end of Combined Reach canal, it has 5 openings with dimensions ( $4 \times 2.3$ ) $\mathrm{m}$ and discharge of $75 \mathrm{~m}^{3} / \mathrm{s}$.

d. Saryah head regulator: It is at the end of Combined Reach canal to the right of Mahrut head regulator, it has 4 openings with dimensions $(4 \times 2.3) \mathrm{m}$ and discharge of $32 \mathrm{~m}^{3} / \mathrm{s}$.

The infrastructures that were mentioned above had been implemented in 1969 .

\subsubsection{Mandaly Irrigation Project}

As it is known, Mandaly area is a border territory known with its orchards and its inhabitants depend on agriculture. Orchards watering are supplied mainly from the Harran Valley, which originates from the Iranian side and feeds as soon as it comes out of the Strait of Komastic, the streams of Falshat, Al-Suwaiq, Jizani, and Mawalih. The Iranian side used water unfairly and river discharges decreased during the 1930s, resulting in a shrinking area of orchards, population migration and a decrease in the number of residents in Mandaly. General Irrigation Directorate studied the issue in the 1930s and 1940s and the choice was to dig wells and pump water into the streams, but this did not work, as the wells were depleted after a period of operation and after studying the area by consultant Sir M. McDonald, several alternatives were analyzed to enhance the area with discharges from Diyala River. The current alternative, an open canal fed from the Combined Reach canal and through a number of pumping stations and pipeline tracks, was chosen to deliver water to Mandaly. 
Mandaly Canal started at the $3.5 \mathrm{~km}$ distance of the Combined Reach canal and continues as an open canal, at the $25 \mathrm{~km}$ distance is pumping station 1 , where this station has 6 pumping units and its maximum discharge is $7.2 \mathrm{~m}^{3} / \mathrm{s}$. The canal passes through a $150 \mathrm{~cm}$ diameter pipe for $2.28 \mathrm{~km}$, which will then be completed as an open canal again. At the $44 \mathrm{~km}$ distance, pumping station 3 , which has six pumping units with discharge capacity of $2.7 \mathrm{~m}^{3} / \mathrm{s}$, feeds agricultural land in Naft Valley. At the distance of kilometer 54 the canal branching into a series of canals feeding the agricultural land as well as there is pumping station no. 2, which includes 6 pumping units with different capacities and discharge of the station amounting to $1.25 \mathrm{~m}^{3} / \mathrm{s}$. This station provides drinking water for the city of Mandaly and watering orchards there.

Mandaly Canal was implemented in the 1970s and subsequently collapsed due to the presence of gypsum layers in the soil, hence, the replacing the lining of concrete with rubber layers in some sections of the canals was considered. The expansion of agricultural areas was planned to achieve the economic feasibility of the project, but the existence of gypsum layers was prevented, and the role of the project became to meet the needs of drinking for humanitarian and social purposes. With a planned net irrigation area of 29,000 dunams, the irrigated area became is 5,044 dunams of orchards and 1,316 dunams of land grown with crops.

Small dams were constructed in Mandaly and Qazania, these dams were soon filled with sediments.

\subsubsection{Ruz Project}

The project is located between Mahrut project and Salah Al-Dein path, which protects the east of the project from floods and drains project's land to Attariya depression, which will be developed in the future to Aziziyah evaporator. Ruz Project feeds through the main Ruz canal, which has a discharge of $38.8 \mathrm{~m}^{3} / \mathrm{s}$. The canals that feed from the main canals up to the $21 \mathrm{~km}$ distance are located within the boundaries of Muqdadiyah project and this distance is not lined. Then the boundaries of Ruz project begin. Reclamation has been under way since 1979 and has achieved a net area of 170,000 dunams. The project's net irrigated area is 230,000 dunams. The canal also supplies drinking water to the city of Baladruz. The reclamation work included the following details within the irrigation and drainage networks:

a. Main and secondary canals, $31.5 \mathrm{~km}$ long lined and $21.5 \mathrm{~km}$ unlined.

b. Branch canals, $309.5 \mathrm{~km}$ long lined and $8 \mathrm{~km}$ unlined.

c. Distributary canals, $1038.4 \mathrm{~km}$ long lined and $272 \mathrm{~km}$ unlined.

d. Irrigation structures, 809 structure.

e. Main Drains, $197 \mathrm{~km}$.

f. Secondary Drains, $340 \mathrm{~km}$

g. Branch Drains, $1,100 \mathrm{~km}$.

h. Field Drains, $4410 \mathrm{~km}$. 


\subsubsection{Muqdadiyah Irrigation Project}

Muqdadiyah Irrigation Project is located between Diyala River and the borders of Ruz, Mahrut and Saryah projects, it is mainly fed by the canals branching from the Combined Reach Canal and the Main Rose Canal within the areas of Muqdadiyah district. The project is one of the oldest projects that have been redeveloped and some canals have been lined between 1982 and 1985. The net area of approximately 73,000 dunams, including 20,964 orchards and 49,872 reclaimed dunams. The most important canals of the project are:

a. North Haroniyah Canal: At the $0.5 \mathrm{~km}$ distance, it is branched from the right side of Combined Reach canal, the discharge of the canal is $1.22 \mathrm{~m}^{3} / \mathrm{s}$.

b. South Haroniyah Canal: At the $3.5 \mathrm{~km}$ distance, it is branched from the left side of Combined Reach canal, the discharge of the canal is $1.7 \mathrm{~m}^{3} / \mathrm{s}$.

c. Muqdadiyah Canal: At the $3.5 \mathrm{~km}$ distance, it is branched from the left side of Combined Reach canal, the discharge of the canal is $6 \mathrm{~m}^{3} / \mathrm{s}$.

d. Group of canals branched from Ruz Canal up to the distance of $21 \mathrm{~km}$, have total discharge of $4.7 \mathrm{~m}^{3} / \mathrm{s}$.

e. Group of canals branched from Combined Reach Canal, have total discharge of $9 \mathrm{~m}^{3} / \mathrm{s}$.

While the irrigation and drainage networks inside the project have the following details, including the above-mentioned canals:

a. Main canals, $15.61 \mathrm{~km}$ long lined and $87.4 \mathrm{~km}$ unlined.

b. Branch canals, $96.7 \mathrm{~km}$ long.

c. Secondary canals, $15.2 \mathrm{~km}$ long lined and $218.6 \mathrm{~km}$ unlined.

d. Main Drains, $96.92 \mathrm{~km}$.

e. Branch Drains, $59.6 \mathrm{~km}$.

f. Field Drains, $289.8 \mathrm{~km}$.

\subsubsection{Mahrut Irrigation Project}

The land of the Mahrut project covers a large area and is partly implemented. The project is located between Ruz and Saryah projects. The project feeds from the Mahrut Canal, which begins at the end of Combined Reach Canal and extends Kanaan Canal, and like the rest of the surrounding projects, the land is drains to Attaryah depression. The main canal of the project was implemented in 1981 and development work was resumed in 2001 and stopped in 2003. The net area of the project is 167,000 dunams. Mahrut Canal is $77.9 \mathrm{~km}$ long, of which $26.14 \mathrm{~km}$ at the beginning is lined. In addition to Kanaan Canal, Al-Izia, Doiylia and Sibana Canals, with total length of $140 \mathrm{~km}$, are branched from the left. The project also includes main drains, which are:

a. Mahrut Main Drain: This drains projects of Muqdadiyah, the north-western part of Ruz project and the eastern parts of the Mahrut project.

b. Northern Sariyah Drain: This drains parts of the Sariyah project and the northwestern parts of Mahrut project.

c. Southern Sariyah Drain: This drains the northern and southern parts Sariyah 
project and part of Mahrut project.

\subsubsection{Sariyah Irrigation Project}

The last project in the series of projects on the left of Diyala Lower, its land is confined between Diyala River and Mahrut project. The project does not include reclamation work, but the work included linking the old canal to Combined Reach canal. The project is one of the most densely populated Diyala River projects and its territory is under continuous urban expansion as many cities are located within the command area of the project, the most important of which is Baquba city.

The net area of the project is 162,000 dunams with 37,000 dunams of land in Tel Asmar, which is located in the project's tail area. There are also 35,000 dunams of orchards. Parts Sariyah canal have been lined when they pass through Baquba and Buhrez. For the land of Tel Asmar, which includes the canals (Shakha 1 and Shakha 2 ), this area suffers from scarcity of water in the summer season. Though, Buhrez pumping station built to support discharge from Diyala River, the station includes 8 metric pumping units (Resources, 2005; Al-Simawi, 2011; Al-Simawi, 2014; Ministry of Irrigation, 2001; Directorate General of Irrigation, 1954).

\subsection{Irrigation Projects on Euphrates River}

Irrigation projects on Euphrates are more related to the history of Mesopotamia, Hilla Branch and Shatt Al-Daghara is the place where the early civilization started in Babylon, Nuffar, Sumer and other spots. For the early of 20th century, Hindiyah Barrage is the first project that implemented to supply projects with irrigation requirements. Later, after commissioning of Development Board, Great Musayab Project is the first projects that had been reclaimed in the 20th century in the 1950s. Finally, during the stage of large advance in reclamation projects implementation in 1970s and 1980s, projects of Great Abu Ghraib, Hilla-Kifl, Hill Branch, Shatt Al-Daghara, Kifl-Shinafiyah and others have a lot of development with different levels.

\subsubsection{Upper Euphrates, Fallujah and Jurf Al-Sakhar Projects}

Some of small and medium sized projects are mainly distributed along Euphrates River in Anbar governorate and north of Babil Governorate. This area, despite its breadth, length of Euphrates reach and population density, is relatively small. One of the reasons is the unsuitability of soil in some areas, as well as the lack of gravity irrigation and the reliance on pumping mainly. The projects referred to are:

\subsubsection{Haditha Dam Reservoir Projects}

These projects have been implemented to compensate those affected by the flooding of Haditha Dam reservoir. These projects are irrigated through earth canals or sprinklers and do not represent projects reclaimed by all means. It feed through floating stations set up on Haditha Dam reservoir or Euphrates River. The implementation was between 1992 and 1996. It can be summarized as follows: 
a. Anah site: land of this site is located in the right of the reservoir of Haditha Dam near the new city of Anah. The net area of the project is 1000 dunams, pumped from a floating station of which the discharge is $0.125 \mathrm{~m}^{3} / \mathrm{s}$. The water is passed through iron pipes of $600 \mathrm{~mm}$ in diameter and 800 meters long.

b. Al-Khor site: land of this site is located in the left of the reservoir of Haditha Dam near Rawa. The net area of the project is 1600 dunams, pumped from a floating station of which the discharge is $0.6 \mathrm{~m}^{3} / \mathrm{s}$. The water is passed through iron pipes of $600 \mathrm{~mm}$ in diameter and 2500 meters long.

c. Kusur Al-Ayman site: land of this site is located in the right of the reservoir of Haditha Dam, northeastern Anah city. The net area of the project is 800 dunams, pumped from a floating station of which the discharge is $0.2 \mathrm{~m}^{3} / \mathrm{s}$. The water is passed through iron pipes of $800 \mathrm{~mm}$ in diameter and 800 meters long.

d. Sagrah site: land of this site is located in the right of the reservoir of Haditha Dam, near Ma'adheid Village. The net area of the project is 1300 dunams, pumped from a floating station of which the discharge is $0.25 \mathrm{~m}^{3} / \mathrm{s}$. The water is passed through iron pipes of $600 \mathrm{~mm}$ in diameter and 1400 meters long.

e. Sakran site: land of this site is located to the left of Euphrates River, downstream f.Haditha Dam. Water is lifted by a pumping station of discharge $0.5 \mathrm{~m}^{3} / \mathrm{s}$ through pipeline of $800 \mathrm{~mm}$ diameter and $10 \mathrm{~km}$ long to the storage reservoir in Sakran Village, where the storage reservoir capacity is 15000 cubic meter. Net area of the project is 1800 dunams, it is irrigated by sprinklers, and the feeding canals of the projects have a total length of $2.5 \mathrm{~km}$.

\subsubsection{Ramadi Irrigation Project}

Ramadi project is located on both sides of Euphrates River from Abu Tayban area northwest of Ramadi to Fallujah. The project, which is divided into six sectors, is based on full pumping and it is partly implemented. The project was studied by Rawafid Company in 1965 and completed in 1970. Works were initiated and the stages were opened between 1980 and 1985. The details of the project sectors are as follows:

a. Sector 1: Located on the right of Euphrates, upstream of Ramadi Barrage, land of the sector irrigated by the main station on Euphrates River, Abu Tayban station which includes 7 metric pumping units, in addition to Zweigher station, which includes two metric pumping units Beziez Zweigher station that includes two half-metric pumping units. This sector has been fully reclaimed through a network of canals and drains for 15.6 thousand dunams. The lined canals have a total length of $85.7 \mathrm{~km}$, while the drains except field drains have a total length of $34.34 \mathrm{~km}$. Drainage water is flowing into Euphrates River through the $1.3 \mathrm{~m}^{3} / \mathrm{s}$ drainage station, which includes two metric pumping units and two pumping units with discharge of $0.45 \mathrm{~m}^{3} / \mathrm{s}$.

b. Sector 2: Downstream sector 1, and is followed by the third sector. This sector is partially reclaimed and irrigated through Qutniyah pumping station which has 5 metric pumping units. The total area of the project is 15,000 dunams, including 
lined canals with lengths of $40.5 \mathrm{~km}$. Drains in this sector has a total length of $9.9 \mathrm{~km}$. Drainage water is flowing into Euphrates River through Zangura Drainage station, which includes a metric pumping unit and a pumping unit with discharge of $0.4 \mathrm{~m}^{3} / \mathrm{s}$.

c. Sector 3: It is downstream sector 2, it is irrigated through the Zangura Irrigation pumping station, which has 5 metric pumping units, also there is Toy pumping station with two metric pumping units. The total area of the project is 12,000 dunams, where the land of this sector has been fully reclaimed and constructed with $42.9 \mathrm{~km}$ of lined canals and $11 \mathrm{~km}$ of drains. Drainage water discharge into Euphrates River through Toy Drainage station that includes a metric pumping unit and another unit with discharge of $0.45 \mathrm{~m}^{3} / \mathrm{s}$.

d. Sector 4: Opposite the previous sectors, the territory of this sector is located on the left side of Euphrates River, which is upstream of Ramadi Barrage. It is irrigated through several pumping stations, which are:

1. Al-Tarabasha Irrigation Station: It comprises two metric pumping units and three units of discharge $0.75 \mathrm{~m}^{3} / \mathrm{s}$.

2. The first station of Beziez Al-Tarabsha: it has two half-metric pumping units.

3. The second station of Beziez Al-Tarabsha: it has two quarter-metric pumping units.

4. Albu-Ali Al-Jassim Irrigation Station: It comprises two metric pumping units and three units of discharge $1.17 \mathrm{~m}^{3} / \mathrm{s}$, as well as two half-metric pumping units .

e. The total land area of the sector is 45,000 dunams and is fully reclaimed, total length of lined canals is $42.9 \mathrm{~km}$ and a total length of drains except field drains is $72.3 \mathrm{~km}$. Drainage water discharged to Euphrates River through Albu-Eitha Drainage Station, which has six metric pumping units.

f. Sector 5: This sector is located downstream of sector 4, and up to ThartharEuphrates Canal. This sector is irrigated through Albu-Thiab pumping station, which has 4 pumping units with $1.17 \mathrm{~m}^{3} / \mathrm{s}$ discharge, and 3 metric pumping units, as well as Albu-Eitha irrigation pumping station, which has two metric pumping units. This sector is partially reclaimed with an area of 55,000 dunams and includes $162.7 \mathrm{~km}$ long drains. The territory of this sector is drained to ThartharEuphrates canal through Siriyah Drainage station, which contains eight metric pumping units.

g. The main drain of the fifth sector, which is connected with that of the fourth stage, has been connected through siphon passing down Tharthar-Euphrates arm with Saqlawiyah main drain, where the later discharging to MOD. Pumping stations are therefore used for emergency purposes only.

h. Sector 6: The territory of this sector lies on the right of Euphrates River near the city of Ramadi; the total area is 114 thousand dunams. It is currently watering through a number of private pumps. Drains has implemented with a total length of $38.6 \mathrm{~km}$, which drains water to Euphrates River through Madheq pumping station, it has six metric pumping units. The sector is partially exploited and its canals are irregularly made. 


\subsubsection{Fallujah-Ameriya Irrigation Project}

The projects is partially-reclaimed project, where the land of the project is located on the right of Euphrates River, the first sector of the project extends from the city of Khalidiya and to the city of Ameriyat Al-Fallujah, and the second sector, which is relatively small, locate to the south of the city Ameriyat Al-Fallujah. The net area of the project is estimated at 55,000 dunams, drainage network were excavated for the first sectors, this sector discharging drainage to Euphrates River through (Ameriya/Fallujah 1) station that includes 5 pumping units with discharge of $1.75 \mathrm{~m}^{3} / \mathrm{s}$ and 4 metric pumping units. The irrigation system is an old earth canal irrigated with private pumps.

\subsubsection{Jurf Al-Sakhar Irrigation Project}

One of the projects exploited on the right of Euphrates River within Jurf Al-Sakhar sub-district in the north of Babylon. The project has a net area of 31,000 dunams, more than 5,000 dunams of which are orchards. The project feeds from a network of canals and pumps, project drainage made through a major drain, from which drainage water pumped into Euphrates River by Jurf Al-Sakhar pumping station, the station includes 6 metric pumping units and two half-metric pumping units (AlMehamdei, 2015; Al-Simawi, 2011; Al-Simawi, 2010).

\subsubsection{Great Abu Ghraib Project}

It is one of the strategic projects in Mesopotamian plain, the land of the project is located the left of Euphrates River and starts from the left of Tharthar-Euphrates Canal to Great Musayab Project, the project is bordered from the north by ThartharTigris Canal, and from the east the city of Baghdad and Tigris River. The project was one of the projects exploited before the development, as its territory was irrigated by Euphrates through the famous ancient canals: Saqlawiya, Abu Ghraib, Yusufiyah, Latifiyah and Eskandariah, head regulator controlling the flow from Euphrates River. After the founding of Supreme Agricultural Board, the idea of constructing of Euphrates Left Canal and Fallujah Barrage, proposed by William Willcocks in 1911, has been raised again. The Dutch company Nedeco has been entrusted for studying the project, and the company has carried out studies and designs since 1975 as well as general supervision of the implementation of the project since the beginning of implementation in 1979. Figure 36 shows a general outline of Great Abu Ghraib Project. The total area of the project that was completed 572,000 dunams, and the project included dozens of pumping stations, which will be detailed later, as well as the following: 


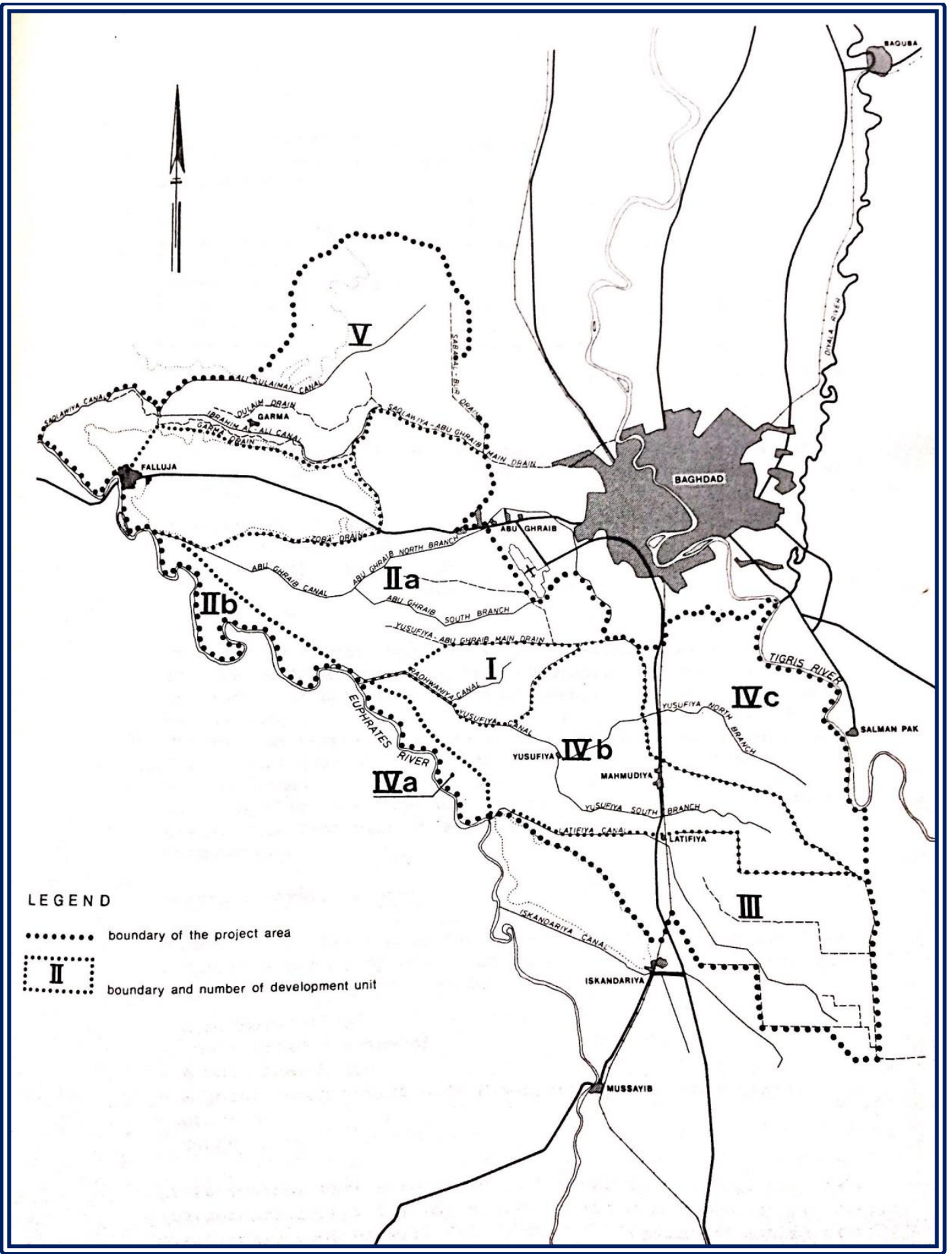

Figure 36: General outline of Great Abu Ghraib Project (Nedeco, 1978). 
1. $1880 \mathrm{~km}$ long paved road network and $10,000 \mathrm{~km}$ of unpaved road network.

2. $1617 \mathrm{~km}$ main, branch canals and distributary canals.

3. $11,000 \mathrm{~km}$ water courses.

4. $2590 \mathrm{~km}$ of drainage canals.

5. $16,000 \mathrm{~km}$ of field drains.

6. 65 million cubic meters of earth works.

7. 82,260 irrigation structure of various sizes.

8. 4.7 million cubic meters of concrete for lining works.

The above quantities represent what is required for the overall development of the project, from which advanced stages have been implemented. Implementation has been initiated since the late 1970 s by foreign companies, and development continued after 1991 only with Iraqi cadres, the progress declined after 2003 due to the security situation in the region, among from the companies that contributed to the implementation of the project in addition to the companies of the Ministry of Irrigation are:

a. Bodemix Polish Company.

b. Turkish Company ZDH.

c. Akrocomplect.

d. Azgo Patior Turkish Company.

In order to detail this large project, it comprises the following parts:

\subsubsection{Fallujah Barrage}

Fallujah Barrage located at Euphrates River at a distance of 5 downstream the city of Fallujah. The barrage has 10 openings controlled by radial gates of dimensions $(8.5 \times 16) \mathrm{m}$; the maximum discharge is $3600 \mathrm{~m}^{3} / \mathrm{s}$ at the maximum operational level $44.79 \mathrm{~m}$ a.s.1. There is fish ladder, and the navigational lock is not implemented, supposed to be implemented in the future. The barrage rise the water to the Combined Canal, that feeding Great Abu Ghraib Irrigation project, this canal is branched from the left side of Fallujah Barrage, where the water discharged through the head regulator which consists of 4 openings of dimensions $(3.5 \times 6) \mathrm{m}$ and has operational discharge of $104 \mathrm{~m}^{3} / \mathrm{s}$.

\subsubsection{The Combined Canal}

The combined canal was created to the left of Euphrates River to draw water from upstream of Fallujah Barrage. It is a $52 \mathrm{~km}$ long earth canal. The canals that branching from the combined canal are Abu Ghraib, Radwaniyah, Yusufiyah and Latifiyah. At the distance of $8 \mathrm{~km}$ from the canal, Abu Ghraib main canal is branching, where the discharge of the canal is $28 \mathrm{~m}^{3} / \mathrm{s}$, the head regulator consists of 3 openings in dimensions $(2.5 \times 3) \mathrm{m}$. At the distance of $30 \mathrm{~km}$, Radwaniyah main canal is branching, canal head regulator has two openings with dimensions $(1.7 \times 2.5)$ and discharging $7.2 \mathrm{~m}^{3} / \mathrm{s}$. At the distance of $36 \mathrm{~km}$, Yusufiyah canal is branching, canal head regulator discharge is $24.4 \mathrm{~m}^{3} / \mathrm{s}$, consisting of two openings with dimensions $(2.5 \times 3) \mathrm{m}$, and at the same location there is a side escape on the right 
side to bypass the excess water to Euphrates River. Finally, at the distance of $52 \mathrm{~km}$ which is the end of the canal, Latifiyah Canal is branching, canal head regulator has a discharge capacity of $23 \mathrm{~m}^{3} / \mathrm{s}$, consisting of 3 openings with dimensions $(2.45 \times 3.25) \mathrm{m}$. At the end also there is a side escape on the right side to bypass the excess water to Euphrates River.

\subsubsection{Saqlawiya Irrigation Project}

Saqlawiya project feeds from Euphrates River, upstream Fallujah Barrage about 18 $\mathrm{km}$ away, back water curve of Fallujah Barrage ensures the sufficient levels of gravity water flow in the project. The net area of the project that irrigated from the Saqlawiya main canal is 113,000 dunams. Under project management, there are lands feed by pumping form Tharthar-Tigris Canal. These located north of the project and are estimated to be 32,000 dunams. Saqlawiya canal is fed by head regulator on the left of Euphrates, a modern regulator built in 2002 as an alternative to the old brick-built regulator. The regulator includes 3 openings of dimensions $(2 \times 4.25) \mathrm{m}$ and passes a discharge of $26 \mathrm{~m}^{3} / \mathrm{s}$. After the head regulator to the right, Azragiah canal is branching, it runs paralleled to Euphrates River. At the hade of the canal is the SF-00 pumping station, which comprises 5 pumping units of discharge $0.8 \mathrm{~m}^{3} / \mathrm{s}$. At the middle of the canal is also Azaragiah station, which support canal discharges form Euphrates, it has a metric pumping unit. The $17 \mathrm{~km}$ long Saqlawiya canal, branching at the end into two lined canal, the first is Ali AlSulaiman Canal, $52 \mathrm{~km}$ long and $11 \mathrm{~m}^{3} / \mathrm{s}$ discharge capacity, this canal irrigate area of 76.5 thousand dunams. The second canal is the $30 \mathrm{~km}$-long Ibrahim al-Ali canal with discharge of $7 \mathrm{~m}^{3} / \mathrm{s}$, the canal irrigate an area of 49.5 thousand dunams. The Drainage network in Saqlawiya consists of the following:

a. $79 \mathrm{~km}$ main drain.

b. Branch drains with length of $377 \mathrm{~km}$.

c. $924 \mathrm{~km}$ of collector drains.

d. $1072 \mathrm{~km}$ of field drains.

The main drain discharge is $24 \mathrm{~m}^{3} / \mathrm{s}$, flowing by gravity to MOD, the main drain is a carrier also for some sectors of Ramadi project as well. The project is partially reclaimed at $25 \%$.

The pumping stations on Tharthar-Tigris canal are irrigating what is known as Garma Project, a project with an estimated area of 32,000 dunams. The details of the stations are as follows:

a. Mishihna pumping station includes 5 metric pumping units and a half-meter pumping unit.

b. Banat Al-Hassan pumping station has 3 pumping units of discharge $0.27 \mathrm{~m}^{3} / \mathrm{s}$.

c. Hamra pumping station has 3 metric pumping units.

d. Issawia pumping station has 3 metric pumping units.

e. Mishihna support pumping station with 3 metric pumping units.

f. Shiha and Albo-Fahad pumping station includes a metric pumping unit. 


\subsubsection{Abu Ghraib Irrigation Project}

The project is irrigated from the combined canal. The main canal of project is 18 $\mathrm{km}$ long lined canal; discharge is $28 \mathrm{~m}^{3} / \mathrm{s}$. At the end, the canal branched into three canals, the northern canal with discharge of $7 \mathrm{~m}^{3} / \mathrm{s}$, the eastern canal with discharge of $8 \mathrm{~m} 3 / \mathrm{s}$ and the southern canal with discharge of $7 \mathrm{~m}^{3} / \mathrm{s}$. The net area of the project is 170,000 dunams, of which 92,000 dunams had implemented with field drains. There are also lands irrigated from the combined canal through 5 pumping stations, 3 pumping stations have been managed by private farmer, and the stations under project management are:

a. Fallujah 3 pumping station, has 3 pumping units, each $0.345 \mathrm{~m}^{3} / \mathrm{s}$ of discharge capacity, and two metric pumping units and a half-metric pumping unit.

b. Fallujah 5 pumping station has 3 pumping units of $1.07 \mathrm{~m}^{3} / \mathrm{s}$ discharge and two metric pumping units.

The project is drained to MOD through several drains and there is a pumping station at the northern section, which is Zubaa pumping station, it has 7 metric pumping units operating when in need.

\subsubsection{Fallujah Irrigation Project}

The lands enclosed between the right of the Combined Canal and the left of Euphrates River, as well as land in the head of the Combined Canal. The project irrigated by private pumps. The net area is estimated at 72,000 dunams.

\subsubsection{Radwaniyah Irrigation Project}

Radwaniyah project is located between Abu Ghraib and Yusufiyah projects, the project feed from the Combined Canal through a $9.5 \mathrm{~km}$ main canal of discharge $7.2 \mathrm{~m}^{3} / \mathrm{s}$. The project is fully developed, where 29,000 dunams of the total area 49,000 dunams was fully reclaimed. The project drains also to MOD.

\subsubsection{Yusufiyah Project}

It is one of the old projects which are irrigated from the ancient Yusufiyah Canal and extends its territory from Euphrates River to Tigris River; Yusufiyah Canal is still in existence and works to supply the land with water. The project is bordered to the north by Abu Ghraib and Radwaniyah projects and to the south by Latifiyah project. After the development of the area within the Great Abu Ghraib project, the lands of Yusufiyah were divided into two parts within the plan, the first partition from Euphrates to MOD which irrigated from the old and new Yusufiyah canal and was called Yusufiyah Project. While the lands after MOD up to Tigris River, is irrigated through the old Yusufiyah Canal, as well as pumping stations on Tigris River, this project is called Hour Rajab project.

In addition to the old Yusufiyah canal, the new Yusufiyah is branching from the Combined Canal with discharge of $24.4 \mathrm{~m}^{3} / \mathrm{s}$, it feeds some of new lined canals as well Shishbar canal with discharge of $10.3 \mathrm{~m}^{3} / \mathrm{s}$ and Halan canal with discharge of $2 \mathrm{~m}^{3} / \mathrm{s}$. The net area of the Yusufiyah project is estimated at 122,000 dunams, of 
which 82,000 dunams were supplied by lined canals, also, a net area of 44,000 dunams has been reclaimed, other areas are under development. Drainage of the project is also connected to MOD.

\subsubsection{Hour Rajab Project}

The land of the project is irrigated east of MOD and west of Tigris River from the old Yusufiyah Canal and pumping stations on Tigris as part of Hour Rajab project. The net area of the project is 95,000 dunams; the reclamation work was initiated in 1999 through the implementation of pumping stations and lining canals. The areas covered by the lining were 65,000 dunams. Drainage network connected also with MOD. Irrigation pumping stations details as follows:

a. First Yusufiyah irrigation station, on Tigris River has 7 metric pumping units.

b. Second Yusufiyah irrigation station, on Tigris River has 6 metric pumping units.

c. Al-Dora irrigation station, on Tigris River has 3 metric pumping units.

d. Al-Rasheed/Manari irrigation station, on Tigris River has 4 metric pumping units.

e. Hour Rajab station, on Tigris River has 5 metric pumping units and a half-meter pumping unit.

f. Sikhraicha station, on Yusufiyah canal, it includes 3 metric pumping units.

\subsubsection{Latifiyah Project}

Latifiyah project is located to the south of the Yusufiyah project and is bordered to the east by MOD and to the west and south by Eskandariah project. The project is mainly fed by the new lined Latifiyah Canal those branches from the end of the combined canal. Some of the lands are irrigated from the old Latifiyah Canal. The net area of the project is 103,000 dunams, new Latitiyah canal is $51 \mathrm{~km}$-long lined canal, and the old Latifiyah earth canal is $34 \mathrm{~km}$ long. The area for which irrigation and drainage networks have been implemented has reached 80,000 dunams.

\subsubsection{Eskandariah Irrigation Project}

Eskandariah project is located at the end of Great Abu Ghraib grand project, although the preliminary design of the project included the connection of the combined canal to the head of the old Eskandariah Canal, but what is currently being fed the project from the Old Eskandariah Canal in addition to the new Eskandariah Canal new that branched from the new Latifiyah Canal at the $29 \mathrm{~km}$ distance. Eskandariah new head regulator at the new Latifiyah canal includes two openings with dimensions $(2.45 \times 3.25) \mathrm{m}$ and the discharge of the system $6.5 \mathrm{~m}^{3} / \mathrm{s}$. The land irrigated from this route is estimated at 20.6 thousand dunams. Eskandariah's old canal is partially lined is fed from Euphrates River and is $18 \mathrm{~km}$ long, the operation of the head regulator of this canal is partly influenced by Hindiyah Barrage, this regulator consists of a single opening of $(2.5 \times 5.8) \mathrm{m}$ dimensions and a discharge of $8 \mathrm{~m}^{3} / \mathrm{s}$. Eskandariah's old canal provides an area of 15,750 dunams. While, the total of the project is 31,000 dunams. Some of the land inside the project is irrigated 
by pumping within Muwailha and Jafjafa canals. The details of the stations are as follows:

a. Muwailha pumping station: pumping water for the Muwailha canal with 5 metric pumping units and a half-meter pumping unit.

b. JafJafa pumping station: pumping water for Jafjafa canal and consist 4 metric pumping units, two half-metric pumping units, and a quarter-metric pumping unit.

c. T Abbas Aba'oub pumping station: the station has two metric pumping units.

The project is draining the water to MOD and to the northern Musayab drain. Within the drainage network, the Eskandariah MN-00 pumping station has 6 metric pumping units and a half-metric pumping unit (Al-Simawi, 2010; Al-Simawi, 2011; Al-Simawi, 2014; Ministry of Irrigation, 2001; Directorate General of Irrigation, 1954; Sousa, 1946).

\subsubsection{Great Musayab Project}

Great Musayab project is one of the old projects where its land was irrigated from the old Cotha Canal. After founding of Development Board, Musayab project was the first project to be reclaimed in Iraq, where the decision to implement the project was taken in 1952 and initiated in 1953, and the development work was completed in 1956. The work mainly consist the development of existing earth canals and excavating of drains at various levels. The net area after the development was 250,000 dunams; later, new area added which is Sumoud farm, whose land is located after the Southern Musayab Drain, with net area of 17,000 dunams. The project feed by gravity from Euphrates River and the irrigation system includes the following details:

1. Musayab head regulator consists of 4 openings with dimensions $(2.9 \times 5) \mathrm{m}$, controlled by radial gates. The maximum discharge of the regulator is $60 \mathrm{~m}^{3} / \mathrm{s}$, and its normal discharge is $40 \mathrm{~m}^{3} / \mathrm{s}$.

2. The main canal which is $49.5 \mathrm{~km}$ long.

3. Branch and secondary canals with total length of $151.5 \mathrm{~km}$.

4. 241 distributary canals, of a total length of $693 \mathrm{~km}$.

Drainage network consists of the following parts:

1. Northern Drain, the length is $47.5 \mathrm{~km}$ and discharge is $15 \mathrm{~m}^{3} / \mathrm{s}$. Part of this drain became a reach of MOD.

2. Southern Drain, is $59.5 \mathrm{~km}$ long and discharge is $29 \mathrm{~m}^{3} / \mathrm{s}$.

3. Branch and secondary drains, of total lengths $197 \mathrm{~km}$.

4. Collector drains of total length $638 \mathrm{~km}$.

5. Open field drains of total lengths $1796 \mathrm{~km}$.

6. Kish pumping station on the southern drain, this station serves Musayab project and Eskandariah-Mahawel project, consisting of three stations in the same location, which are:

a. New Kish pumping station has 5 pumping units, each $3,375 \mathrm{~m}^{3} / \mathrm{s}$.

b. Old Kish pumping station has 5 pumping units, each of discharge $1.6 \mathrm{~m}^{3} / \mathrm{s}$.

c. Kish horizontal pumping station has 3 metric pumping units. 
Great Musayab project generally needs sophisticated rehabilitation work. All of its canals are earth and most of the canals design section and slopes were changed as a result of improper maintenance, a large number of brick-built structures have become out of work and bypass have been made around the structures (Al-Simawi, 2010; Water Resources Directorate in Babylon, n.d.; Al-Simawi, 2011; Al-Simawi, 2014; Resources, 2005).

\subsubsection{Eskandariah-Mahawel Project}

Eskandariah-Mahawel project is located between the borders of the Eskandariah project Great Musayab projects to the east and Euphrates River to the west, and is bordered to the south by Hilla Branch Babil Canal. The project is divided into three phases:

Phase 1: The land which is fed mainly from Hilla Branch upstream Babail Canal, the area is 125,000 dunams. The canals that feed the project are:

1. Mahawel Canal: The canal is branching from Hilla Branch at the distance of $8 \mathrm{~km}$, extends up to $20 \mathrm{~km}$, at the head there is a regulator with discharge of $10.7 \mathrm{~m}^{3} / \mathrm{s}$. The canal passes through the city Mahawel, also a pumping station with 13 metric pumping units has been installed near the head to support discharges.

2. Khatouniyah Canal: Branching at the $25 \mathrm{~km}$ distance of the left of Hilla Branch, $5.4 \mathrm{~km}$ long and discharge is $1.4 \mathrm{~m}^{3} / \mathrm{s}$.

3. Fandiyah Canal: Branching at the $25.5 \mathrm{~km}$ distance from the left of Hilla Branch, $8 \mathrm{~km}$ long and discharge is $0.9 \mathrm{~m}^{3} / \mathrm{s}$.

4. Nile Canal: Branching at the $27 \mathrm{~km}$ distance from the left of Hilla Branch, 17.88 $\mathrm{km}$ long and $3.5 \mathrm{~m}^{3} / \mathrm{s}$ discharge.

5. The left side Babil Canal: the right side are within the boundaries of the HillaHashimia project. The canal is branched at a distance of $27.3 \mathrm{~km}$ from the left of Hilla Branch, one of the largest branching streams of Hilla Branch, with length of $36 \mathrm{~km}$ and a discharge of $15 \mathrm{~m}^{3} / \mathrm{s}$.

Phase 2: This phase is feed from Nasiriya Canal, a fully reclaimed phase also called the Nasiriya Project. The territory of this stage is located south of Musayab Canal, and the canal of Nasiriya is branched from the left of Euphrates River at a distance of $8 \mathrm{~km}$ upstream of Hindiyah Barrage, head regulator has two openings with dimensions of $(1.8 \times 3) \mathrm{m}$ and discharge $4.7 \mathrm{~m}^{3} / \mathrm{s}$. The irrigation system within the project consists of:

1. Nasiriya's main lined canal is $12.8 \mathrm{~km}$ long.

2. Secondary canals with length of $24 \mathrm{~km}$.

3. $65.8 \mathrm{~km}$ distributary canals.

4. $130.75 \mathrm{~km}$ water courses.

All canals of the project are lined and cover the project area of 13,000 dunams. The project, as well as the first phase of the Eskandariah-Mahawel project, is being drained through drainage network. This network, which flows into the Southern Musayab Drain, where Kish pumping station contributes to discharge the drainage 
water, drainage network consists the following parts:

1. $22.5 \mathrm{~km}$ main drains.

2. $103 \mathrm{~km}$ branch drains.

3. $104 \mathrm{~km}$ secondary drains.

4. $590 \mathrm{~km}$ collector drains.

Drainage pumping station No.22, within the network of Nasiriya project, which includes 8 metric pumping units.

Phase 3: The land of this stage lies between the Eskandariah canal and Musayab canal and feeds through private pumps on the left of Euphrates. The area of this phase is 25.7 thousand dunams and a number of its land is currently being exploited as lakes for fish farming, which are also spread through other phases of the project (Al-Simawi, 2011; Al-Simawi, 2014; Water Resources Directorate in Babylon, n.d.; Mousa, 2017).

\subsubsection{Husseinia and Bani Hassan Projects}

After building of Hindiyah Barrage, the canals of Husseinia and Bani Hassan were dug, Husseinia Canal to deliver water to the city of Karbala and Bani Hassan Canal to irrigate the lands to the right of Euphrates downstream Hindiyah Barrage, as well as Karbala Drain from 1928 to 1931. The development of the project was studied at Development Board era by Nedeco for the period from 1954 to 1956 . It was followed by studies from Iraqi entities, the most important of which are the design departments in the Ministry of Irrigation. The project is divided into two parts:

\subsubsection{Husseinia Project}

The project feeds mainly from the recently lined Husseinia Canal. The canal is $28 \mathrm{~km}$ long and its maximum discharge is $55 \mathrm{~m}^{3} / \mathrm{s}$. This project feeds agricultural land, Karbala orchards and drinking needs for Karbala. The net area of the project is 112.5 thousand dunams, of which 56,000 dunams are orchards. From Husseiniya Canal several canals were branched which are Al-Wand, Kamalyah, Al-Jadida, Abu Zara' and Hindiyah. At the end of the project, the $22 \mathrm{~km}$ long Rushdiyah Canal is branched out.

The Drainage network covers an area of 96,000 dunams of the project and drains water to the main drain, which ends with pumping station which lifts water to Razzaza Lake, drainage water lifted through Razzaza pumping station, that consists of two pumping sets, the first is Razzaza vertical station consists of 5 pumping units of $3.8 \mathrm{~m}^{3} / \mathrm{s}$ discharge capacity, and the second is Razzaza support station, it consists 12 metric pumping units.

One of the things that Karbala city experiencing is the rise in groundwater levels, so the drainage system plays an important role in controlling this problem. The city of Karbala is also had an official and informal urban expansion which reduce the area of the project day by day. 


\subsubsection{Bani Hassan Project}

The project is located to the right of Euphrates River for the distance from Hindiyah Barrage to Kifl area. From the east, the project is bordered by Euphrates River and from the west by Karbala-Najaf road. The project is mainly fed from the newlylined Bani Hassan Canal, where the canal is $68 \mathrm{~km}$ long and its maximum discharge is $45 \mathrm{~m}^{3} / \mathrm{s}$. The net area of the project is 105.5 thousand dunams. Irrigation network is mainly earth canals connected to the main canal, Bani Hassan Canal, the total length of these canals is $149.3 \mathrm{~km}$ and irrigated area is 82.5 thousand dunams. Drainage network consists of three sections implemented in the 1960s as follows: Northern section: Its land is drained by Imam Mansour drain, which reaches discharge of $6 \mathrm{~m}^{3} / \mathrm{s}$, and is linked to Husseinia drains.

a. Central section: Its territory is drained to Euphrates River through Sichla Drainage station; it includes 3 pumping units with $1.25 \mathrm{~m}^{3} / \mathrm{s}$ discharge capacity and 6 metric pumping units.

b. Southern section: Its land is drained by Abu Fishaiga drain, which extends to the south of the project, and pumping drainage water to Euphrates River through Southern Husseinia pumping station, the station includes two pumping sets, the first set of 3 pumps of discharge $1.8 \mathrm{~m}^{3} / \mathrm{s}$ and the second set of 3 half metric pumping units. There is also in southern section, what is so called Khurus pumping station, which lifts water from Khurus drain and has two metric pumping units (Al-Simawi, 2010; Al-Simawi, 2011; Al-Simawi, 2014; S. A. Board, 1977; Directorate General of Irrigation, 1954).

\subsubsection{Hilla-Kifl Project}

It is one of the old projects that were fed from Kifl Canal, which modified later after building of Hindiyah Barrage. The project is located between Hindiyah Barrage and the city of Kifl, bordered to the west by Euphrates River and to the east by Hilla Branch and Hilla-Kifl road.

The areas to the south of Hindiyah Barrage are generally distinguished by rising groundwater levels. Due to the spread of salinity, Tewerej Drainage network for parts of project land was implemented in 1954. Nedeco carried out a study and designs for the drains of Hilla-Kifl, also the 55.5km-long Hilla-Kifl main drain was completed in 1959 to serve the land in the project. The project was later studied by Swiss consultants and completed the study in 1984. Reclamation work was initiated in 1982, works were begun by Romanian companies, where the reclamation of the northern and central sectors was carried out. After 2006, at various intervals, the reclamation of the southern sector was initiated, as well as the lining of Kifl Canal, which is still on going. The net area of the project is 152,000 dunams.

The irrigation system is fed by three canals branching from Kifl Canal, which are:

1. Pumping canal: A $17.74 \mathrm{~km}$ lined canal supplied with water through a pumping station built near Kifl Canal with 6 metric pumping units and 3 half-metric pumping units. The path of this canal is adjacent to Hilla Branch.

2. Hilla Canal: A $51 \mathrm{~km}$ lined canal with discharge of $14.2 \mathrm{~m}^{3} / \mathrm{s}$. This canal passes 
from the center of the project and its route is adjacent to Hilla city and the eastern edge of the project.

3. The Kifl Canal: the extension of the old Kifl, as the upstream reach of it is $6.9 \mathrm{~km}$ long and is considered a main canal that supplies the Pumping and Hilla canals, and then the path of the old canal is the current canal of Kifl, which has been partially lined. The canal is $50.25 \mathrm{~km}$ long and discharge capacity is $18.5 \mathrm{~m}^{3} / \mathrm{s}$. The canal runs along Euphrates River and ends at the city of Kifl, a supporting pumping station called the Abu Jamus has been installed with two metric pumping units to raise water from Euphrates River to the canal.

There are more canals in the irrigation network, branch, secondary and distributary canals with total length of $291 \mathrm{~km}$, and water courses with total length of $2507 \mathrm{~km}$. The Drainage network discharge to Eastern Shamia drain, and the main Hilla-Kifl drain is the backbone of the project to drain the lands, it is connected by branch drains with total length of $243 \mathrm{~km}$ and collector drains with total length of $1150 \mathrm{~km}$, while the field drains are estimated within the areas covered by the reclamation is 6696km (Al-Simawi, 2011; Al-Simawi, 2014; Al-Simawi, 2011; Water Resources Directorate in Babylon, n.d.; Mahmoud, 2011). Figure 37 shows a map of Hilla-Kifl Irrigation Project.

\subsubsection{Hilla Branch Projects}

Hilla Branch and its extension of Shatt Al- Diwaniyah are one of the ancient routes of Euphrates River; also, it is the most important branch that feed from Euphrates River to irrigate the territory of Babylon, Qadisiyah and Muthana governorates, in addition to provide drinking needs for cities on its course. Hilla-Diwaniyah area was studied by Nedeco from 1958 to 1960 for the first time, dividing the project into four sectors; Nedeco again submitted a study on the drainage network in the region in 1972. Then a study was presented also by Nedeco in 1986, which included 9 sectors, 3 right of Hilla Branch and three each for right and left of Shatt Al-Daghara. Hilla Branch projects consist of the following:

\subsubsection{Hilla Branch}

Hilla Branch according to the irrigation management extends from Hindiyah Barrage to the head of Shatt Al-Diwaniyah, for a length of $101 \mathrm{~km}$. The maximum discharge of this reach is $245 \mathrm{~m}^{3} / \mathrm{s}$. It was planned to expand the capacity to pass a $300 \mathrm{~m}^{3} / \mathrm{s}$. Along Hilla Branch are the following regulators:

a. Doora Regulator: South of Hilla city at a distance of $51.1 \mathrm{~km}$. The regulator consists of 6 openings with dimensions $(6 \times 9) \mathrm{m}$, the maximum discharge is $249 \mathrm{~m}^{3} / \mathrm{s}$. To the right of the regulator is a $6 \times 90 \mathrm{~m}$-dimension navigation lock.

b. Al-Tayas Regulator: South of Midhatiyah city at a distance of $76 \mathrm{~km}$. The regulator consists of 5 openings with dimensions $(6 \times 9) \mathrm{m}$, the maximum discharge is $206 \mathrm{~m}^{3} / \mathrm{s}$. To the right of the regulator is a $6 \times 90 \mathrm{~m}$-dimension navigation lock, the regulator was opened in 1982 . 
c. Shatt Al-Diwaniyah head regulator: this regulator together with head regulator of Shatt Al-Daghara were opened in 1928, a new regulators have been re-built as an alternative to the old ones. New Shatt Al-Diwaniyah head regulator was opened in 2010 and consists of 4 openings with dimensions $(3.75 \times 6) \mathrm{m}$, it is controlled by radial gates to pass a maximum discharge of $96 \mathrm{~m}^{3} / \mathrm{s}$.

d. Shatt Al-Daghara head regulator: The new regulator of Shatt Al-Daghara was opened in 1980 and is located upstream of Shatt Al-Diwaniyah head regulator, consisting of 3 openings with dimensions $(4 \times 6) \mathrm{m}$, the regulator controlled by radial gates to pass a maximum discharge of $96 \mathrm{~m}^{3} / \mathrm{s}$, while the normal discharge is $55 \mathrm{~m}^{3} / \mathrm{s}$. 


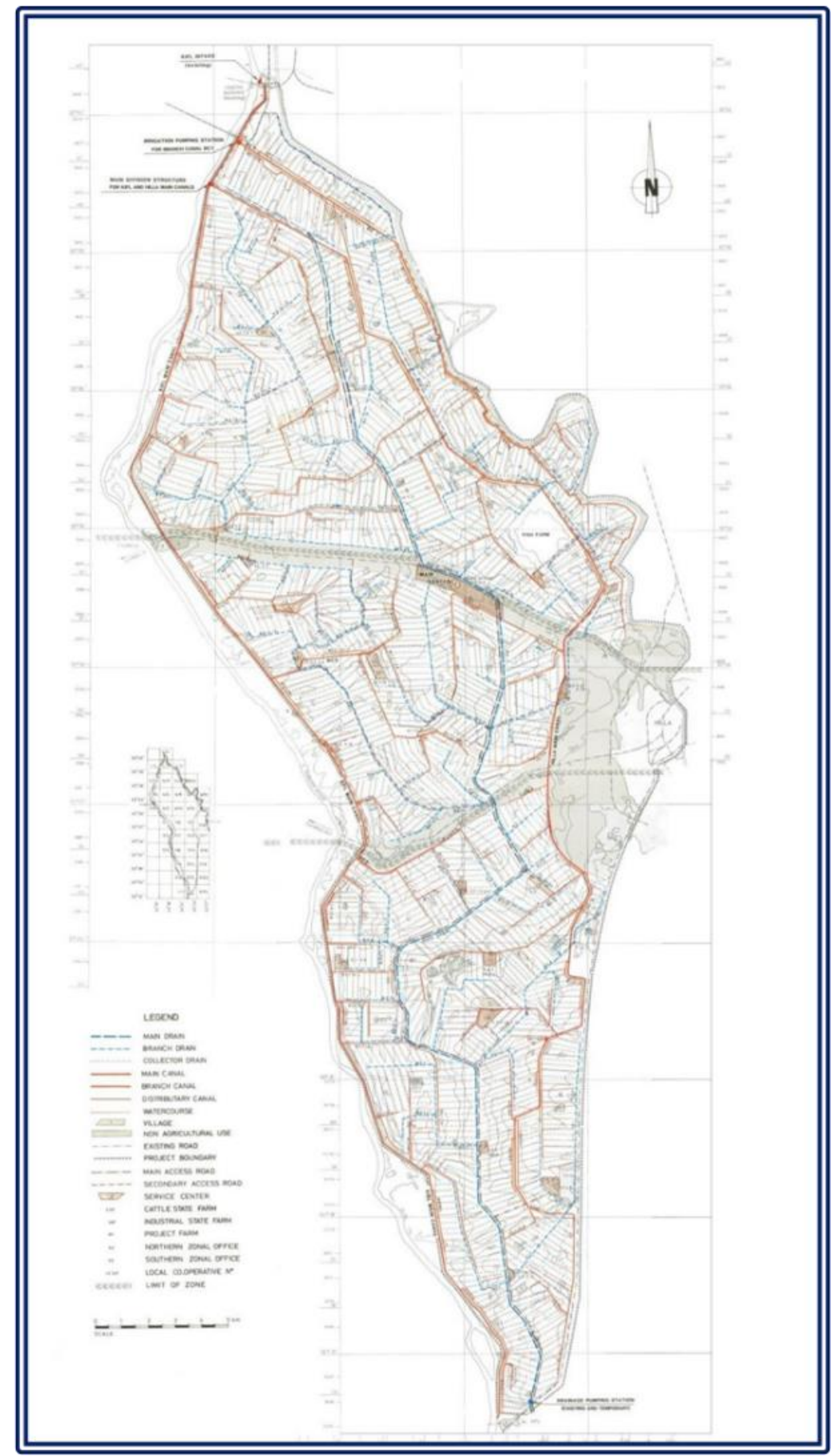

Figure 37: General map of Hilla-Kifl Irrigation Project. 


\subsubsection{Hilla-Hashimia Project}

The lands on the left of Hilla Branch, from the right of Babil Canal to the left of Dhulmia Canal. No study about the project was made after that of Nedeco, until Euphrates Center for Studies and Design prepared a study of the integrated irrigation and drainage network in 1990. Drainage network up to collector drains were implemented between 1993 and 1995. In addition to a pumping station, that was constructed in 1996. The irrigated area covered by the project's canals is 410,000 dunams, of which 240,000 dunams covered by drainage network. Irrigation Network consists of Babil Canal, which was mentioned earlier in Hilla-Eskandariah project and a number of canals which feed by gravity or private pumps, the most important of which are:

a. Wardia Canal: Branching at the $36.9 \mathrm{~km}$ distance from Hilla Branch. Canal length is $8.1 \mathrm{~km}$ long and the discharge is $1.3 \mathrm{~m}^{3} / \mathrm{s}$. Canal head regulator consists one opening of dimension $(1.25 \times 1.5) \mathrm{m}$.

b. Bermana Canal: Branching at the $57.4 \mathrm{~km}$ distance from Hilla Branch. Canal length is $9 \mathrm{~km}$ long and the discharge is $1 \mathrm{~m}^{3} / \mathrm{s}$. Canal head regulator consists one opening of dimension (1x1.3) $\mathrm{m}$.

c. Meshaimish Canal: Branching at the $61.7 \mathrm{~km}$ distance from Hilla Branch. Canal length is $8.1 \mathrm{~km}$ long and the discharge is $0.7 \mathrm{~m}^{3} / \mathrm{s}$. Canal head regulator consists one opening of dimension $(1 \times 1.2) \mathrm{m}$.

d. Rubianah Canal: Branching at the $70.26 \mathrm{~km}$ distance from Hilla Branch. Canal length is $5.5 \mathrm{~km}$ long and the discharge is $0.7 \mathrm{~m}^{3} / \mathrm{s}$. Canal head regulator consists one opening of dimension (1x1.2) $\mathrm{m}$.

e. Bashya Canal: Branching at the $74.7 \mathrm{~km}$ distance from Hilla Branch. Canal length is $9 \mathrm{~km}$ long and the discharge is $0.7 \mathrm{~m}^{3} / \mathrm{s}$.

f. Kedis Canal: Branching at the $76.6 \mathrm{~km}$ distance from Hilla Branch. Canal length is $9 \mathrm{~km}$ long and the discharge is $0.7 \mathrm{~m}^{3} / \mathrm{s}$. Canal head regulator consists one opening of dimension $(1.4 \times 0.8) \mathrm{m}$.

g. Khamisiah Canal: Branching at the $76.68 \mathrm{~km}$ distance from Hilla Branch. Canal length is $25.45 \mathrm{~km}$ long and the discharge is $6 \mathrm{~m}^{3} / \mathrm{s}$.

h. Awadel Canal: Branching at the $76.95 \mathrm{~km}$ distance from Hilla Branch. Canal length is $15.4 \mathrm{~km}$ long and the discharge is $2.7 \mathrm{~m}^{3} / \mathrm{s}$. Canal head regulator consists two openings of dimension $(1 \times 1.2) \mathrm{m}$.

i. Zebar Canal: Branching at the $81.12 \mathrm{~km}$ distance from Hilla Branch. Canal length is $0.9 \mathrm{~km}$ long and the discharge is $081 \mathrm{~m}^{3} / \mathrm{s}$.

j. Um Al-Wared Canal: Branching at the $88.7 \mathrm{~km}$ distance from Hilla Branch. Canal length is $30 \mathrm{~km}$ long and the discharge is $3.5 \mathrm{~m}^{3} / \mathrm{s}$.

k. Shomeli Canal: Branching at the $90.2 \mathrm{~km}$ distance from Hilla Branch. Canal length is $35.5 \mathrm{~km}$ long and the discharge is $6.2 \mathrm{~m}^{3} / \mathrm{s}$.

1. Dhulmia Canal: Branching at the $95.84 \mathrm{~km}$ distance from Hilla Branch. Canal length is $32 \mathrm{~km}$ long and the discharge is $7.1 \mathrm{~m}^{3} / \mathrm{s}$. The land to the left of this canal is in the boundaries of Hilla- Hashmia hill project, while the land to the right, is within the boundaries of Hurriya-Daghara project. 
Drainage network consists of the following:

a. Main drain with total length of $93.3 \mathrm{~km}$.

b. Branch and secondary drains with total length of $343 \mathrm{~km}$.

c. collector drains with total length of $318 \mathrm{~km}$.

d. Al-Shomeli drainage station, which pumps the water to MOD, where it has 3 pumping units of $5.3 \mathrm{~m}^{3} / \mathrm{s}$ discharge per each. The length of the carrier canal from the station to MOD is $20 \mathrm{~km}$.

\subsubsection{Hilla-Diwaniyah Project}

Hilla-Diwaniyah project is no different from the Hilla-Hashimia project except that it feeds from the right side of Hilla Branch through other canals. Drainage network is connected to East Shamiya drain. The project is a part of the Hilla-DiwaniyahDaghara project, which was submitted by Nedeco, this was divided into two projects, the first involving 3 sectors of the right of Hilla Branch, named after HillaDiwaniyah project, and the second includes the sectors of Shatt Al-Daghara. The net area Hilla-Diwaniyah project is 282,000 dunams. Development of the project was implemented by the Greek company Scapaneus, which was initiated in 1975 , but the project is still a partially-reclaimed project. The irrigation system in the project includes several canals, the most important of which are:

a. Tajiah Canal: Branching at the $45.75 \mathrm{~km}$ distance from Hilla Branch. Canal length is $8.77 \mathrm{~km}$ long and the discharge is $0.65 \mathrm{~m}^{3} / \mathrm{s}$. Canal head regulator consists one opening of dimension $(1.5 \times 0.6) \mathrm{m}$.

b. Qadisiyah Canal: Branching at the $47.6 \mathrm{~km}$ distance from Hilla Branch. Canal length is $32.2 \mathrm{~km}$ long and the discharge is $8.1 \mathrm{~m}^{3} / \mathrm{s}$. Canal head regulator consists two openings of dimension $(1.2 \times 1.5) \mathrm{m}$. Qadisiyah Canal supported by First Irwaiyah pumping station, which includes 3 pumping units, each discharging $0.75 \mathrm{~m}^{3} / \mathrm{s}$.

c. Doora Canal: Branching at the $51.8 \mathrm{~km}$ distance from Hilla Branch. Canal is partially lined and its length is $25 \mathrm{~km}$ long, the discharge is $3.6 \mathrm{~m}^{3} / \mathrm{s}$. Canal head regulator consists two openings of dimension $(1.2 \times 1.5) \mathrm{m}$.

d. Himeinia Canal: Branching at the $54.37 \mathrm{~km}$ distance from Hilla Branch. Canal length is $8.5 \mathrm{~km}$ long and the discharge is $0.62 \mathrm{~m}^{3} / \mathrm{s}$.

e. Wesmi Canal: Branching at the $54.9 \mathrm{~km}$ distance from Hilla Branch. Canal length is $4.2 \mathrm{~km}$ long and the discharge is $0.2 \mathrm{~m}^{3} / \mathrm{s}$.

f. Elaj Canal: Branching at the $56.47 \mathrm{~km}$ distance from Hilla Branch. Canal length is $31.5 \mathrm{~km}$ long and the discharge is $6.8 \mathrm{~m}^{3} / \mathrm{s}$. Canal head regulator consists two openings of dimension (1 x 2) $\mathrm{m}$.

g. Abu Qamchi Canal: Branching at the $60.2 \mathrm{~km}$ distance from Hilla Branch. Canal length is $7.68 \mathrm{~km}$ long and the discharge is $0.58 \mathrm{~m}^{3} / \mathrm{s}$.

h. Amadiya Canal: Branching at the $61.97 \mathrm{~km}$ distance from Hilla Branch. Canal length is $11.2 \mathrm{~km}$ long and the discharge is $1.1 \mathrm{~m}^{3} / \mathrm{s}$.

i. Jarboua'ya Canal: One of the large canals branching from the right of Hilla Branch, such as Qadisiyah and Haidari and Wardia Canals. This canal, 
branching at the $62.6 \mathrm{~km}$ distance from Hilla Branch. Canal length is $29.35 \mathrm{~km}$ long and the discharge is $9.63 \mathrm{~m}^{3} / \mathrm{s}$. Canal head regulator consists two opening of dimension $(2 \times 1.5) \mathrm{m}$. Canal is supported by Second Irwaiyah pumping station, the station includes 3 pumping units of $1.5 \mathrm{~m}^{3} / \mathrm{s}$ discharge capacity.

j. Hashmia Canal: Branching at the $65 \mathrm{~km}$ distance from Hilla Branch. Canal length is $13.13 \mathrm{~km}$ long and the discharge is $1 \mathrm{~m}^{3} / \mathrm{s}$.

k. Bazul Canal: Branching at the $85.75 \mathrm{~km}$ distance from Hilla Branch. Canal length is $4.5 \mathrm{~km}$ long and the discharge is $0.71 \mathrm{~m}^{3} / \mathrm{s}$.

1. Ebaikher Canal: Branching at the $88.15 \mathrm{~km}$ distance from Hilla Branch. Canal length is $5.8 \mathrm{~km}$ long and the discharge is $0.53 \mathrm{~m}^{3} / \mathrm{s}$.

m. Haidari Table: One of the large canals where it branches at the $\mathrm{km} 90.35$ distance from Hilla Branch, it also extends within the boundaries of Qadisiyah governorate and reaches the length of the table to $28.27 \mathrm{~km}$ and discharged $7.42 \mathrm{~m}^{3} / \mathrm{s}$. Canal head regulator has two openings with dimensions of $(2 \times 3.2)$ $\mathrm{m}$.

Drainage network in this project, which flows into Eastern Shamia Drain, consists of the following:

a. $32.19 \mathrm{~km}$ main drain.

b. Branch drains with total length of $266 \mathrm{~km}$.

c. Secondary drains with total length of $511.36 \mathrm{~km}$.

d. Collector drains with total length of $832 \mathrm{~km}$ (Resources, 2005; Al-Simawi, 2011; Construction, 1989; S. A. Board, 1977; Water Resources Directorate in Babylon, n.d.; Mousa, 2017).

\subsubsection{Hurriya-Daghara Project}

It is one of the important and large projects that feed mainly from Shatt Al-Daghara, in addition to the right of Dhulmia Canal and Hurriya Canal which are branching from Hilla Branch and Sharifiya Canal, which is branched from the left of Shatt AlDiwaniyah. This project covers 6 sectors of the Hilla-Diwaniyah-Dagarh project. Most of the project's land is exploited through old canals and there are reclaimed sectors, some of which are still in the process of being reclaimed. A new $23 \mathrm{~km}$ of Shatt Al-Daghara was excavated in 1952, replacing the old route and being linked to the rest of the old route to the length of Shatt Al-Daghra to $65 \mathrm{~km}$. The net area of the project is approximately 643,000 dunams. One of the best sectors of the project in terms of completing the work of lining and reclamation is Sector 4, which includes Thuraima Canal and Right Jannabia Canal, where the Bulgarian company Akrocomplecet developed this sector, and carried out the full reclamation for an area of 65,000 dunams. The development of Sector 7 of the project was initiated in 2001 and is still under development. The irrigation system consists of canal described in Table 3 below, as well as right side of Dhulmia Canal. Most of the project's land is irrigated by gravity, except for Abu Sabkha canal, some of the lands in the boundary of the canal irrigated by pumping, a pumping station on canal route of seven metric pumping units. The project covered by a large drainage network 
that collects and discharge drainage water to MOD. There are two main drains in the project, the first drain MD III to the left of Shatt al-Daghara, with a length of approximately $75 \mathrm{~km}$, and the second drain MD IV to the right of Shatt al-Daghra, with a length of approximately $53 \mathrm{~km}$ (Resources, 2005; Al-Simawi, 2011; AlSimawi, 2014; Al-Musawi, 2015; Al-Zamilie, 2017).

Table 3: Canals of Hurriya-Daghara Project (Al-Musawi, 2015; Al-Zamilie, 2017).

\begin{tabular}{|c|c|c|c|c|c|}
\hline Canal Name & $\begin{array}{l}\text { Canal } \\
\text { Type }\end{array}$ & $\begin{array}{c}\text { Canal } \\
\text { length } \\
(\mathbf{k m})\end{array}$ & $\begin{array}{c}\text { Canal } \\
\text { discharge } \\
\left(\mathbf{m}^{3} / \mathbf{s}\right) \\
\end{array}$ & $\begin{array}{l}\text { Branching } \\
\text { Side }\end{array}$ & $\begin{array}{l}\text { Kilometric } \\
\text { distance of } \\
\text { branching }\end{array}$ \\
\hline \multicolumn{6}{|c|}{ From Hilla Branch } \\
\hline Hurriya & Earth & 6 & 7 & Left & 101 \\
\hline \multicolumn{6}{|c|}{ From Shatt Al-Diwaniyah } \\
\hline Sharifiyah & Lined & 15.6 & 2.86 & Left & 0.34 \\
\hline \multicolumn{6}{|c|}{ From Hurriya Canal } \\
\hline North Hurriya & Earth & 3 & 18.6 & Tail & 6 \\
\hline South Hurriya & Earth & 2 & 24.3 & Tail & 6 \\
\hline \multicolumn{6}{|c|}{ From Shatt Al-Daghara } \\
\hline Abu Sabkha & Lined & 11.9 & 5.95 & Right & 10.9 \\
\hline Um Al-Sukhaila & Earth & 4.4 & 0.4 & Right & 15 \\
\hline Um Henain & Lined & 6.3 & 0.5 & Right & 16.15 \\
\hline Warshana & Earth & 3.5 & 0.5 & Right & 18.14 \\
\hline Fawara & Lined & 9.7 & 2 & Right & 19.19 \\
\hline Main Jo'an & Lined & 15.2 & 8.5 & Right & 20.13 \\
\hline Tubar Shekheir & Earth & 10.9 & 5.3 & Left & 27.32 \\
\hline Al-Fani & Earth & 13.3 & 2 & Left & 28.3 \\
\hline New Jo'an & Earth & 9 & 1.7 & Right & 30.3 \\
\hline Nuffar Canal & Earth & 4.3 & 0.6 & Left & 31.7 \\
\hline Al-Kheir & Earth & 14.5 & 3 & Right & 32.1 \\
\hline Nuffar River & Earth & 14.4 & 2.8 & Left & 39.3 \\
\hline Main Juheish & Lined & 27.6 & 4.5 & Left & 41 \\
\hline Thuraima & Lined & 52 & 38.5 & Right & 42.39 \\
\hline Noniah & Lined & 7 & 0.4 & Left & 43.1 \\
\hline Efach & Lined & 17.5 & 2 & Left & 43.38 \\
\hline Aradat & Lined & 4.2 & 0.6 & Left & 60.25 \\
\hline Kafarat & Earth & 4.17 & 0.4 & Left & 61.5 \\
\hline Limfawiyah & Lined & 3.8 & 0.3 & Left & 62.6 \\
\hline Right Jannabiya & Lined & 30.6 & 8 & Right & 64 \\
\hline Left Jannabiya & Lined & 27.1 & 6.4 & Left & 64.1 \\
\hline $\begin{array}{c}\text { Shatt Al-Daharra } \\
\text { Tails }\end{array}$ & Earth & 24.48 & 1.9 & Tail & 65 \\
\hline
\end{tabular}




\subsubsection{Shatt Al-Diwaniya Projects}

Few canals are branching form Satt Al-Diwaniya, starting from Shatt Al-Diwaniya head regulator till Ruamaitha project boundary, the lands of the project is not reclaimed yet, and many canals depends on private pumps.

After Hilla Branch, Shatt Al-Diwaniya continues for a distance of approximately $120 \mathrm{~km}$ and discharge is $60 \mathrm{~m}^{3} / \mathrm{s}$. A cross regulator is located in Siniya sub district at the $34.5 \mathrm{~km}$ distance Shatt Al-Diwaniya. Due to the high levels of groundwater in Diwaniya city and the implementation of a new head regulator for Shatt AlDiwaniya and its increased discharge, and to secure water for cities located downstream, Shatt Al-Diwaniya Diversion Canal has been implemented. It is a 27.9 $\mathrm{km}$ long, $45 \mathrm{~m}^{3} / \mathrm{s}$ discharge capacity lined canal, which passes two-thirds of the discharge and one-third of the discharge is left to run in Shatt Al-Diwaniya within its original course within the city of Diwaniya.

The canal begins from the right Siniya regulator and continues along the borders of the city of Diwaniya and flows into Shatt Al- Diwaniy at the distance of 62 kilometers.

Upstream Siniya regulator also, New Shafiya Canal is branching, a $30 \mathrm{~km}$ long earth canal and discharge is $15.7 \mathrm{~m}^{3} / \mathrm{s}$, a new pumping station comprising 4 units has been implemented on Shatt Al-Diwaniya Diversion Canal, with the aim supporting discharges of New Shafiya for future reclamation. Also, Old Shafiya Canal, an earth canal that branches at a distance of $35.82 \mathrm{~km}$ from Shatt AlDiwaniya, the canal extends $7.8 \mathrm{~km}$ long and its discharge $1 \mathrm{~m}^{3} / \mathrm{s}$.

The remaining distance within Diwaniya and Hamza districts from Shatt AlDiwaniya is watered through earth canals and private pumping stations (Al-Simawi 2014; Al-Simawi; 2010; Al-Zamilie, 2017).

\subsubsection{Rumaitha Irrigation Project}

It is one of the old projects at the tails Hilla Branch, where it irrigates the land of the Rumaitha district. From 1940 to 1954, General Irrigation Directorate organized irrigation in the project and constructed canals and regulator. Project has two sections of a 144,000-dunam winter irrigation section and a summer irrigation area of 35.5 thousand dunams. The irrigation system within the project consists of several canals, the most important of which are:

1. Al-Hechaimi Canal: The length of the canal is $20 \mathrm{~km}$ and discharge of $3.36 \mathrm{~m}^{3} / \mathrm{s}$, canal head regulator has one opening with dimensions of $(1.5 \times 3) \mathrm{m}$.

2. A'wja Canal: The length of the canal is $13.5 \mathrm{~km}$ and discharged of $2.21 \mathrm{~m}^{3} / \mathrm{s}$, canal head regulator has one opening with dimensions of $(1.5 \times 3) \mathrm{m}$.

3. Qazwini Canal: The length of the canal is $18 \mathrm{~km}$ and discharge of $2.27 \mathrm{~m}^{3} / \mathrm{s}$, canal head regulator has one opening with dimensions of $(2.2 \times 3.75) \mathrm{m}$.

4. Nu'mani Canal: The length of the canal is $6 \mathrm{~km}$ and discharge of $1.36 \mathrm{~m}^{3} / \mathrm{s}$, now feed from Shatt Al-Rumaitha Support Canal.

5. A'rdhiat Canal: The length of the canal is $18 \mathrm{~km}$ and discharge of $18 \mathrm{~m}^{3} / \mathrm{s}$.

6. Nejmei Canal: The length of the canal is $10 \mathrm{~km}$ and discharge of $1.6 \mathrm{~m}^{3} / \mathrm{s}$, canal 
head regulator has one opening with dimensions of $(1.7 \times 3.1) \mathrm{m}$.

7. Abu Sekhair Canal: The length of the canal is $4 \mathrm{~km}$ and discharge of $1.5 \mathrm{~m}^{3} / \mathrm{s}$, canal head regulator has one opening with dimensions of $(1 \times 1.2) \mathrm{m}$.

Further, there is the important Gat'aa Regulator on Shatt Al-Ruamaitha, which consists of 4 openings of dimensions $(2.2 \times 3.75) \mathrm{m}$ and passes a discharge of $9.55 \mathrm{~m}^{3} / \mathrm{s}$. The project was studied by Nespac Company from Pakistan and has drawn up plans for the necessary lining and reclamation work. In 1971, Dar Baghdad Company also prepared a study about the main project drains, consisting of main Rumaitha Drain of length $58 \mathrm{~km}$, the main Qazweini Drain with length of $38 \mathrm{~km}$ and the Eastern Drain with length of $37.5 \mathrm{~km}$. Excavations of the main drains for the project were made, which was flowing into Euphrates River, now connected to Eastern Euphrates Drain. Due to of the scarcity of water that affected Iraq in 1999, and as Rumaitha lands in the tails Hilla Branch system. A new canal built to support Rumaitha with water, it is Shatt Al-Rumaitha Support, and it feed from the upstream of Khawarnaq Regulator near the city of Ghamas, which is part of the KiflShinafiyah project. Canal was implemented within 3 months in 2000 and is a $64.5 \mathrm{~km}$-long, $15 \mathrm{~m}^{3} / \mathrm{s}$ discharge capacity lined canal (Al-Simawi, 2011; Al-Simawi, 2014; Al-Simawi, 2011; Directorate General of Irrigation, 1954; Ministry of Irrigation, 2001).

\subsubsection{Kifl-Shinafiyah project}

Kifl-Shinafiyah project is one of the old existing. The project begins from the branching of Euphrates River near Kifl city to Kufa and Shamiya Branches and ends when they meet near the city of Shinafiyah. The project is an important and socially complex. The project was initially studied by the U.S. company TAMS in 1958 to develop river navigation in the region. From 1975 to 1978, Selkhozpormexport Company conducted investigations and studies and submitted its report in 1980 . The French company Sugrea then developed the designs of the regulator on Kufa and Shamyia Branches, although there are regulators at the end of Kufa Branch carried out during the 1930s and 1950s. The designs of the main drains were then developed by Nespac Company, namely Eastern Euphrates, Western Shamyia and the Najaf Sea Drains. The Indian consultant WAPCOS also prepared the designs of the irrigation and drainage networks for the Kifl-Shinafiyah project, the report was submitted in 1983, with net area of 664,000 dunams.

One of the phenomena prevalent in this region is what is known as the phenomenon (Nagarat), which is a waterfall developed in the river due to the difference and as a result of the occurrence of the waterfall and the erosion of the point of its estuary the waterfall moves upstream, causing a decrease in the levels of rivers and affecting irrigation. The project comprises a number of major Barrages and regulators, and it has been considered that the navigation route on Kufa Branch as the largest branch and the route of the approved river navigation line. The Barrages in the project are Kuafa, Meshkhab and Abu Ashraa Barrages, while the main regulators are Abbasiyah, Shamiya, Khawarnaq and Al-Ya'aw Regulators. 
Irrigation network in the project is mainly composed earthen canals which feeds Shamyia and Kufa Branches. Table 4 and Table 5 below illustrate the branching of the canals within Kifl-Shinafiyah project.

Table 4: Canals branching from Kufa Branch (Elaiwy, 2018).

\begin{tabular}{|c|c|c|c|}
\hline Canal name & Discharge $\left(\mathrm{m}^{3} / \mathbf{s}\right)$ & Length $(\mathbf{k m})$ & $\begin{array}{c}\text { Irrigated area } \\
\text { (thousands dunams) }\end{array}$ \\
\hline Chahat & 28 & 33.4 & 27.25 \\
\hline Sedeir & 3.2 & 28 & 9.5 \\
\hline Abu Gedha' & 4.2 & 18 & 9 \\
\hline Bedairiyah & 8 & 26.5 & 24 \\
\hline Hashimiy & 2.2 & 13 & 12.3 \\
\hline Shahriyah & 4.2 & 4.2 & 15.2 \\
\hline Turra & 4 & 4.2 & 2 \\
\hline Azzamiyah & 4 & 3 & 1 \\
\hline Jala'awiy & 2 & 4 & 1 \\
\hline Keshikheil & 1 & 3 & 1.15 \\
\hline Bachay & 1 & 2 & 0.5 \\
\hline Abu Dananer & 3.2 & 5.8 & 1.8 \\
\hline A'rfy & 3.2 & 4.1 & 1.45 \\
\hline Malha wal Daham & 1 & 2.5 & 1.1 \\
\hline Mejehleiah & 2 & 3.2 & 1.8 \\
\hline Debaineiah & 15 & 9.1 & 6.19 \\
\hline Sewariah & 16 & 8.1 & 1.29 \\
\hline Right Jannabia & 9 & 9.3 & 7.35 \\
\hline Shallal & 12 & 9.5 & 9.6 \\
\hline Sayed Alwan & 1 & 2 & 0.4 \\
\hline Mawlani & 1 & 2.7 & 1.45 \\
\hline A'yesh & 1 & 9.2 & 0.96 \\
\hline Gat'at Al-Marashdah & 1 & 2.6 & 0.63 \\
\hline Gat'at Al-Zurfan & 1 & 2.5 & 1.26 \\
\hline Left Jannabia & 10 & 6.1 & 7.15 \\
\hline Al-Leithawi & 5 & 4.1 & 0.95 \\
\hline Al-Ehaimer & 6 & 8.9 & 2.5 \\
\hline Abdullah Al-Majeed & 3.5 & 2.7 & 0.45 \\
\hline Abu Al-Dejaeij & 1 & 3.3 & 0.75 \\
\hline Al-Rufai' & 2 & 4.9 & 0.75 \\
\hline Bezaiz Shatt Al-Ghazali & 3 & 7.8 & 0.95 \\
\hline Da'ariah & 1 & 2.3 & 0.4 \\
\hline Um Al-Housh & 1 & 2.5 & 0.45 \\
\hline Tubar Hamadi & 12 & 9 & 13.5 \\
\hline Tubar Al-Jawasim & 1.5 & 3 & 1.3 \\
\hline Shiblawi & 6 & 6.9 & 8.5 \\
\hline Qadisiya & 9 & 9.4 & 4 \\
\hline
\end{tabular}


Table 5: Canals branching from Shamiya Branch (Elaiwy, 2018).

\begin{tabular}{|c|c|c|c|}
\hline Canal name & Discharge $\left(\mathrm{m}^{3} / \mathrm{s}\right)$ & Length (km) & $\begin{array}{c}\text { Irrigated area } \\
\text { (thousands } \\
\text { dunams) }\end{array}$ \\
\hline Haidari & 9 & 16 & 12 \\
\hline Al-Adel & 1.5 & 4 & 1.5 \\
\hline Wahabi & 9 & 18 & 10 \\
\hline Abu Gharab & 9 & 16 & 12 \\
\hline A'ryan & 5 & 15.7 & 5 \\
\hline Fatha & 9 & 15.7 & 5.5 \\
\hline Al-A'ma & 9 & 7 & 5 \\
\hline Ayashy & 1 & 1.6 & 1.5 \\
\hline Um Hayaia & 9 & 9 & 10 \\
\hline Abu Khora & 5 & 4.5 & 5 \\
\hline Abu Dawanech & 1 & 3.5 & 1 \\
\hline Al-Zayde & 7 & 6.9 & 3 \\
\hline Vartical Al-Masy & 12 & 18 & 12 \\
\hline Mehanawiyah & 12 & 21 & 2.5 \\
\hline Cheihan & 2 & 12 & 5 \\
\hline A'gar & 2 & 5.6 & 3.2 \\
\hline Ghudheib & 1 & 9 & 2.75 \\
\hline Hadady & 1 & 7 & 0.65 \\
\hline Mehdi Al-Asal & 2 & 5 & 4.68 \\
\hline Najarmah & 9 & 5 & 14.1 \\
\hline Gharbasha & 1.5 & 9 & 2.35 \\
\hline Ghashaniyah & 4 & 4 & 6.27 \\
\hline Daragha & 3 & 4 & 4.73 \\
\hline Mu'abrah & 2 & 14 & 2 \\
\hline Feidha & 2 & 4 & 4.7 \\
\hline Tubar Al-Ibrahim & 6 & 3.5 & 12 \\
\hline Hawi & 2 & 10 & 4.6 \\
\hline Abu Halan & 0.5 & 10 & 0.9 \\
\hline Dhahi Al-humood & 1 & 4 & 1.35 \\
\hline Al-Negheil & 1 & 11 & 2 \\
\hline Al-Nehas & 1 & 6 & 3 \\
\hline Neghaisheiah & 0.5 & 4 & 1 \\
\hline
\end{tabular}


It is noticeable that no canal is branching from Kufa Branch until Manathra district. Among the canals referred to Sedeir Canal, which is the only one that feeds Najaf Sea region.

The reclamation for small sector in the project to the right of Shamiya Branch was initiated in 2008 and for a square of 12,000 dunams.

Drainage network is mainly Eastern and Eastern Shamiya Drains, which flows into Euphrates River. Drainage network includes a number of pumps, which are:

1. Northern Kufa pumping station with two metric pumping units and a pumping unit of discharge $0.75 \mathrm{~m}^{3} / \mathrm{s}$.

2. Southern Kufa pumping station with two metric pumping units.

3. Kasrat Chahat pumping station which includes 3 metric pumping units.

4. Bakriya Drainage pumping station which includes a half-metric pumping unit.

Finally, it is worth to mention that in 1993 a support canal which called Qadisiya Canal were dug, started from the upstream of Abu Ashra Barrage and flow towards Atshan Branch to the south of Shinafiyah in order to support discharges in Atshan which is a branch of Euphrates (Resources, 2005; Al-Simawi, 2011; Al-Simawi, 2014; Al-Simawi, 2011; Elaiwy, 2018; Sousa, 1946).

\subsubsection{Lower Euphrates Projects}

These are projects that located on Euphrates downstream Shinafiyah city in Muthana and Dhi Qar governorates. These projects are mainly among large, unfinished future projects, namely, Shinafiyah-Nasiriya, Muthana and Souq alShoyukh. Lower Euphrates projects include:

\subsubsection{Pumping Irrigation Projects in Muthana Governorate}

Small projects which are watered by pumping from Euphrates River within Muthana governorate, the pumping stations were established before 2003 as part of the farming campaigns. Its details are in Table 6 below.

Table 6: Pumping irrigation projects in Muthana Governorate (Al-Simawi, 2011).

\begin{tabular}{|c|c|c|}
\hline Project/Station Name & $\begin{array}{c}\text { Irrigated Area } \\
\text { thousand dunams) }\end{array}$ & Design Discharge $\left(\mathbf{m}^{\mathbf{3}} / \mathbf{s}\right)$ \\
\hline Al-Khedhir & 10 & 3 \\
\hline Tal Al-gut & 10 & 4 \\
\hline Al-Tubba & 20 & 1 \\
\hline Al-Bedeir & 4 & 1 \\
\hline Al-Ghadeir & 10 & 3 \\
\hline Siweir tails & 20 & 1 \\
\hline Al-Kheir & 5 & 1 \\
\hline Al-Kawthar & 10 & 3 \\
\hline
\end{tabular}




\subsubsection{Muthana Irrigation Project}

One of the proposed projects in Muthana governorate, where its boundary lies between Shatt Al-Siweir and Euphrates River, was presented by Swiss consultants in 1981. Its net area at the time of development is 48,000 dunams. It is currently irrigated by canals and pumps, which is an irregular irrigation system, while the Drainage network was implemented after 2005 and includes a main drain and a number of branch and secondary drains in addition to a pumping station that raises the drainage water to Eastern Euphrates Drain, the station includes 3 pumping units, each of which discharges $1.35 \mathrm{~m}^{3} / \mathrm{s}$.

\subsubsection{Euphrates Tail system}

When Euphrates at Souq Al-Shuyokh district, the river branched into a series of branches that feed agricultural canals in the area. The development of the area was studied by TAMS in 1952, and a number of barrages and regulators were built later. These are Ghlewen Regulator, Ekaikah Barrage, Garmat Hassan Regulator and Haffar Barrage (Al-Simawi, 2010; Al-Simawi, 2011).

\subsubsection{Al-Kheir Projects}

Although the status of these projects is not currently clear, they are considered cancelled projects. However, some of the land of these projects is still being exploited by farmers, and some are currently flooded. With the fact that some canals may be submerged or studied, the size of these projects, which amounted to nearly one million dunams, justify the importance to know about these projects. Al-Kheir projects started to reclaim land from the marshes in 1996 and the work was extended until 2003. Among the projects are:

1. Hour Odeh project in Al-Salam sub district of Maysan governorate, with an area of 2,100 dunams.

2. Wawyah project in Majar district, with an area of 6,400 dunams.

3. Maleha project in Hammar Marsh to the right of Euphrates River, the area was 122,000 dunams.

4. Shafi project, to the right of Euphrates in Souq Al-Shoyukh district, the area was 122,000 dunam, this project is a sector form the planned Shatt Al-Arab Irrigation Project.

5. Right Euphrates in the district of Souq Al-Shoyuk, with an area of 40,000 dunams

6. Um Nakhla project in Garamat Bani Sa'eid, the area was 80,000 dunams.

7. Many projects on Glory River.

There is currently no statistics or proven description of the status of projects and as of the year 2000, the cost of 27.6 billion IQD was spent. (Ministry of Irrigation, 2001). 


\subsection{Main Drains}

A main drain has been proposed between Tigris and Euphrates for the first time in Willcocks report. The first study of the master plans of the main drains was presented by the American company TAMS in 1952, where it proposed the path of the MOD and to flow in Hammar Marsh. Many of the main drains have been implemented, and there are still proposed and studied drains such as East Tigris Drain and Western Euphrates Drain.

There are other proposed drains such as East Tigris Drain, West Euphrates Drain, and some of the evaporation lakes, but still no action.

\subsubsection{Main Outfall Drain (MOD)}

MOD is the backbone of drainage in Mesopotamian plain, extending from the end of the Ishaqi project and continuing to Shatt Al-Basra which is connected to Arab Gulf, the length is $565 \mathrm{~km}$. MOD is draining an estimated 6 million dunams of land, completed in 1992.

After the study by TAMS, a study by Sir M. McDonald in 1963 was presented regarding the drainage in Mesopotamia. By the early 1970s, Soviet companies were contracted to carry out excavations of MOD, where the first phase were excavated from 1973 until 1977, this is the middle sector where the path was $156 \mathrm{~km}$ long. Then, Philip Hullzmann and Polenski were contracted to implement the southern sector, after adopting an alternative proposal to link MOD to Arab Gulf instead of Hammar Marsh. This phase was completed in 1986, Basra Bay were developed also for a distance of $44 \mathrm{~km}$.

In 1984, the Brazilian company Mendes began implementing Siphon structure and pumping station on Euphrates River, then, the company left the site in 1990, without completing the work in its final form. For the period 1981-1983, Nedeco prepared a study about the Northern sector which is linked to Ishaqi main drains.

Finally, Iraqi companies began implementing the northern sector and expanding the middle sector and completed their work in 1992. MOD consists of the following parts:

\subsubsection{Northern Sector}

It starts from the end Ishaqi project drains to Dalmaj Lake, where it passes through siphon structure below Tharthar-Tigris Canal. This sector is $206 \mathrm{~km}$ long and the discharge capacity $98 \mathrm{~m}^{3} / \mathrm{s}$ at Dalmaj Lake site.

\subsubsection{Middle Sector}

This sector starts from the north of Dalmaj Lake to the intersection of MOD with Euphrates River. The route within this section is $187 \mathrm{~km}$ long and discharge is $200 \mathrm{~m}^{3} / \mathrm{s}$, it is functioning as a navigation route for river vessels. One of the most important parts of this sector is Lake Dalmaj, an ancient marsh first used as an evaporation lake for the drainage of Musayab project in 1956. The lake has a capacity of 200 million cubic meters and a surface area of $200 \mathrm{~km}^{2}$. It is surrounded 
by a $72 \mathrm{~km}$ dykes. The role of Dalmaj Lake is to act as a balance reservoir within the course of MOD. The following facilities are also located within this sector:

a. Cross regulator on MOD in the distance of 330 kilometers. This system consists of 4 openings with dimensions $(4 \times 4) \mathrm{m}$ and passes a maximum discharge of $100 \mathrm{~m}^{3} / \mathrm{s}$. It is in the final stages of implementation. This regulator controls the discharges entering Dalmaj Lake.

b. Outlet regulator of Dalmaj Lake, which is located at the beginning of the drainage canal that links Dalmaj Lake to MOD. The regulator consists of 4 openings of dimensions $(3 \times 3.5) \mathrm{m}$, it was completed in 1988 .

c. Cross regulator on MOD in the distance of 249 kilometers. This system consists of 3 openings with dimensions $(3 \times 3.5) \mathrm{m}$. It is located upstream of the drainage canal that links MOD with Dalmaj Lake, to maneuver with discharges. It was completed it in 1990.

d. Emergency Escape, located at the $172 \mathrm{~km}$ distance, upstream the pumping station by $11 \mathrm{~km}$. This escape does the function of passing excess water to nearby marshes in case the pumping station stops. The escape consist an escape canal located on the left of MOD and a head regulator consisting of 10 openings with dimensions $(2.5 \times 4) \mathrm{m}$ of discharge capacity $200 \mathrm{~m}^{3} / \mathrm{s}$. This escape was implemented in 2012.

\subsubsection{Southern Sector}

This sector starts from the pumping station and the siphon to Shatt Al-Basra Shatt. The length of the route is $172 \mathrm{~km}$ and discharge capacity is $300 \mathrm{~m}^{3} / \mathrm{s}$. Also, it is functioning as a navigation canal, which is connected to the middle sector by navigation locks that did not implemented yet, these planned navigation locks are located at the intersection of MOD with Euphrates River. This sector includes the following facilities:

a. MOD Pumping Station: the station is upstream the siphon structure, at the 161 $\mathrm{km}$ distance, one of the largest pumping stations in MENA region, and the largest pumping station in Iraq. The station lifts the water of MOD to the inlet of the siphon. The implementation of the station was started in 2002 and opened in 2008 and comprises 12 pumping units, each of which is $20 \mathrm{~m}^{3} / \mathrm{s}$ discharge capacity. Figure 38 shows a general view of MOD pumping station from the inside.

b. Siphon Structure at intersection with Euphrates River: Siphon structure consists of three openings, two in service and one standby. The dimensions of each opening are $(4 \times 5) \mathrm{m}$, the length of the siphon below Euphrates river is $320 \mathrm{~m}$, and the discharge capacity is $200 \mathrm{~m}^{3} / \mathrm{s}$ can pass. Figure 39 shows and outline for the intersection of Euphrates River and MOD.

c. Shatt Al-Basra Regulator: The last structure located on MOD at the distance of $\mathrm{km}(0)$. The regulator consists of two sets of gates. The first group is 5 gates with dimensions $(4 \times 4) \mathrm{m}$ and the second group two flood gates with dimensions of $(4 \times 6) \mathrm{m}$. The gates pass the discharge of $500 \mathrm{~m}^{3} / \mathrm{s}$. The regulator includes a 
fish ladder and a navigational lock with dimensions of $(16.5 \times 191) \mathrm{m}$. The regulator was completed in 1973. It was damaged due to the military actions that accompanied the occupation of Iraq in 2003. Hence; it is currently out of service (Al-Simawi, 2011; Al-Simawi, 2011; Al-Simawi, 2014; Al-Jabbari and Nawfal, 2001; Al-Simawi, 2010).

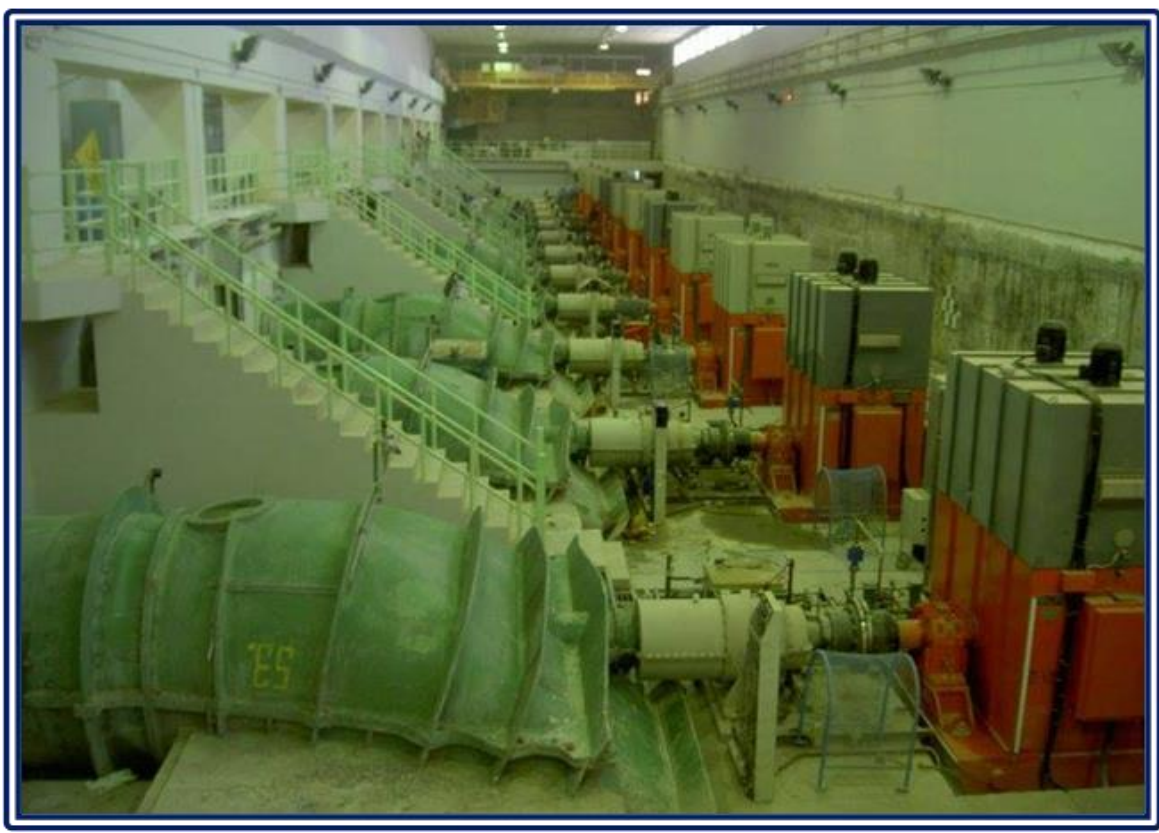

Figure 38: General view of MOD pumping station from the inside. (MoWR n.d.) 


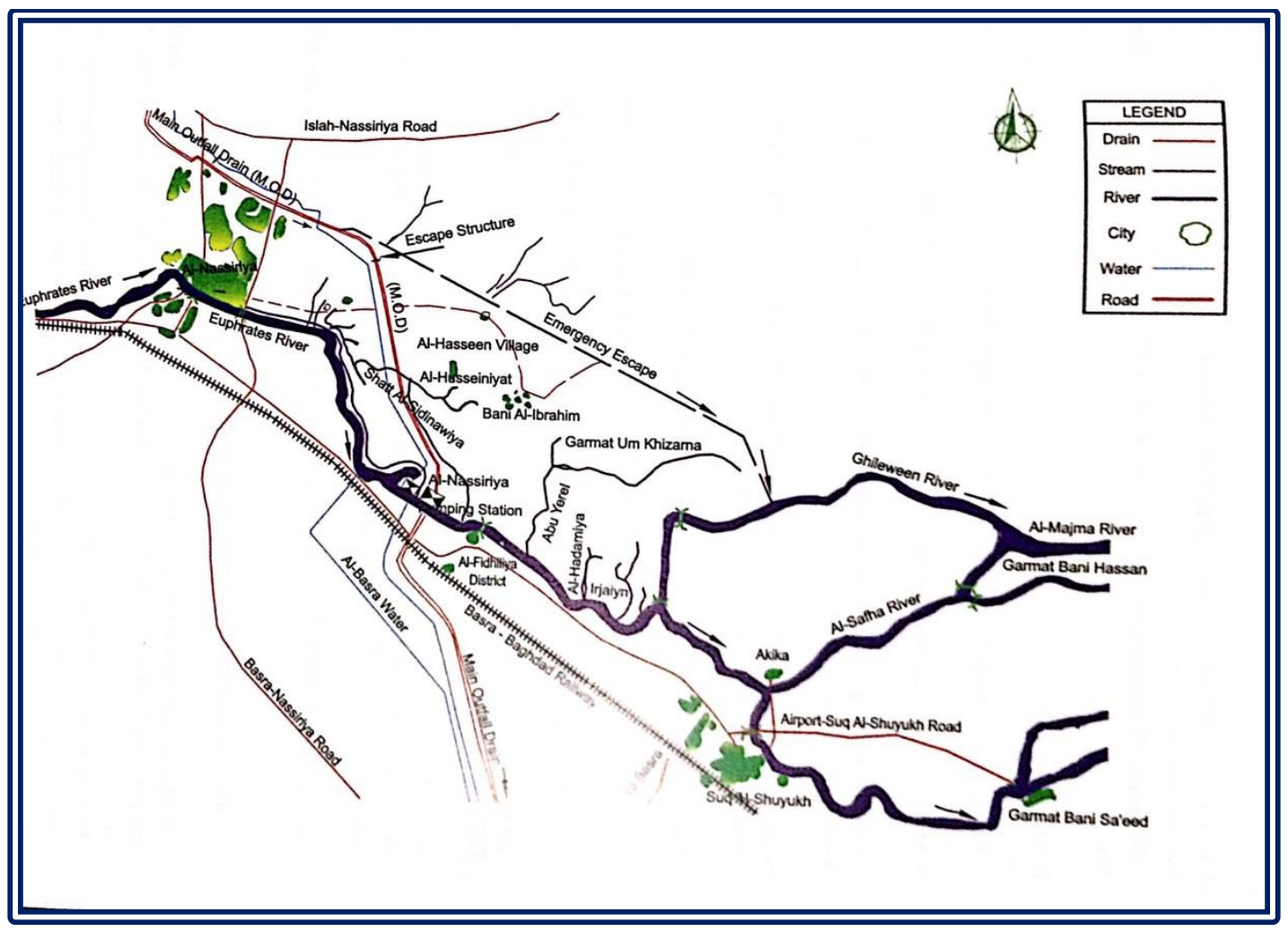

Figure 39: Outline of the intersection of Euphrates River and MOD (MoWR 2005).

\subsubsection{Eastern Euphrates Drain}

It is one of the main and partially implemented drains. After full development, the drain is $261 \mathrm{~km}$ long and the discharge capacity is $85 \mathrm{~m}^{3} / \mathrm{s}$. It is connected with MOD at the $189 \mathrm{~km}$ distance. The project was started in 2001 and it is an ongoing project. Two main drains are connected with this drain, Eastern Shamiya, which became part of Eastern Euphrates Drain and the Western Shamiya. Eastern Euphrates Drain is carried out until the border of Kifl-Shinafiyah project, but the connection with the drains of project has not been completed, where siphon structure is required under Shamiya Branch to pass the waters of the Western Shamyia Drain. Regarding Shamiya Drains, the detail as following:

\subsubsection{Eastern Shamiya Drain}

This drain is a part of Eastern Euphrates Drain of the kilometer distance (168-261). The implementation started by General Irrigation Directorate in 1943 and was developed in later stages, to drain the projects of Hilla-Kifl, Hilla-Diwaniya, and parts of Kifl-Shinafiyah project.

At the beginning of the drain, the evaporator is Hour Ibin Najem, which is used as a balance reservoir to reduce the peak discharge Eastern Shamiya Drain, where the evaporator has an area of 16.7 thousand dunams. This drain continues to flow into 
Euphrates River in Shamiya Branch and causes a rise in the salinity of the water.

\subsubsection{Western Shamiya Drain}

This drain is disposing the drainage water between Kufa Branch and Shamiya Branch. Implementation of the drain was started in 1953 and is still being expanded after the completion of the Designs of Kifl-Shinafiyah project. The drain is $74 \mathrm{~km}$ long and the discharge after development is $30.3 \mathrm{~m}^{3} / \mathrm{s}$. It currently flows into Shamiya Branch and has the same negative impact on Euphrates River as Eastern Shamiya Drain (Al-Simawi, 2011; Al-Simawi, 2010; Ministry of Irrigation, n.d.).

\subsubsection{Great Gharraf Drain}

It is one of the main drains and was also called Shatra Drain, which is $157 \mathrm{~km}$ long and its discharge is $46 \mathrm{~m}^{3} / \mathrm{s}$. It is draining the lands of Middle-Tigris project in addition to Dalmaj and West Gharraf projects. Great Gharraf Drain is connected with MOD at the $217 \mathrm{~km}$ distance; also West Gharraf is flowing in this drain (AlSimawi, 2011). 


\section{References}

[1] Adamo, N., Al-Ansari, N., Sissakian, V., Knutsson, S. and Laue, J. (2018). Mosul Dam: Full Story (in Arabic).

[2] Adamo, N., Sissakian, V., Al-Ansari, N., Elagely, M., Knutsson, S. and Laue, J. (2018). Comparative Study of Mosul and Haditha Dams in Iraq: Different Construction Materials Contribute to Different Designs. Journal of Earth Sciences and Geotechnical Engineering Vol.8, No.2, pp.71-89. https://www.researchgate.net/publication/323486528_Comparative_Study_of _Mosul_and_Haditha_Dams_in_Iraq_Different_Construction_Materials_Con tribute_to_Different_designs.

[3] Adamo, N., Sissakian, V., Al-Ansari, N., Knutsson, S. Laue, J., and Elagely, M. (2018). Comparative Study of Mosul and Haditha Dams, Iraq: Foundation Treatments in the Two Dams. Journal of Earth Sciences and Geotechnical Engineering, Vol.8, No.2, pp.53-70.

https://www.researchgate.net/publication/323486448_Comparative_Study_of _Mosul_and_Haditha_Dams_Iraq_Foundation_Treatments_in_the_Two_Da ms.

[4] Al-Hakeem and Hussein, A. (2015). Studies in Iraqi Agriculture: Part 2 (in Arabic).

[5] Al-Husseinawi, Y., Zhenhong, L., Clarke, P. and Edwards, S. (2018). Evaluation of the Stability of the Darbandikhan Dam after the 12 November 2017 Mw 7.3 Sarpol-e Zahab (Iran-Iraq Border) Earthquake. Remote Sensing 10 (9): 1426. https://doi.org/10.3390/rs10091426.

[6] Al-Jabbari, Hussein, M. and Fadhil Nawfal, B. (2001). Saddam River (in Arabic).

[7] Al-Mehamdei and Menawir , A. H. (2015). Integrated Management of Water Resources in Anbar Governorate (in Arabic). Saint Kleimnts.

[8] Al-Musawi, Dua'a Mousa. (2015). Hydrology of Shatt Al-Daghara, Study in Natural Geography.

[9] Al-Simawi, H. (2008). Encyclopedia of Dams in Iraq.

[10] Al-Simawi, H. (2010). Irrigation and Drainage Projects in Iraq.

[11] Al-Simawi, H. (2011). Irrigation and Drainage Pumping Stations in Iraq (in Arabic).

[12] Al-Simawi, H. (2014). Irrigation Regulators in Iraq Until the End of the Year 2013.

[13] AL-Simawi, H. (2011). Large Main Drains in Iraq and Their Status until 2011.

[14] Al-Ta'i, Matheel (2015). Effect of Influent Point of Atharthar Lake on the Distribution of Water Quality. Baghdad.

[15] Al-Zamilie, Karrar Hamza (2017). Spatial Analysis of Agricultural Land Use in Diwaniyah District.

[16] Annunziato, A., Andredakis, I. and Probst, P. (2016). Impact of Flood by a Possible Failure of the Mosul Dam. Joint Research Centre. https://doi.org/10.2788/689469. 
[17] Ararat, Korsh, Raid Abdul, Mehdi, Haider Ahmed, Falih, Ali Mohammed Maher, and Bachmann, A. (2008). Darbandikhan Lake Poisoning Event.

[18] Board, Development (1956). Development Board Publication.

[19] Board, Supreme Agricultural (1977). Large and Medium Agricultural Projects (in Arabic).

[20] Irrigation Development Commission (1951). The Control of the Rivers of Iraq and the Utilization of Their Waters.

[21] Construction, Rafidain Company for Dams (1989). Flood Wave of ThartharEuphrates Main Regulator (in Arabic).

[22] Consulting Engineering Bearue, University of Baghdad (2011). Lakes Testing.

[23] Darbandikhan Official Account on Facebook. n.d. Accessed June 1, 2019. https://www.facebook.com/DerbendikhanDam.

[24] Designs, Directorate General of Engineering (2008). Feasibility Study of Middle Tigris Irrigation Project (in Arabic).

[25] Directorate General of Irrigation (1954). Report about Directorate General of Irrigation Works for a Five Years from 1949 to 1954 (in Arabic).

[26] Elaiwy, H. K. (2018). Geographical Distribution of Water Resources in Middle Euphrates.

[27] Hachim, A. H. (2018). Nishama Escape (Unpublished, in Arabic).

[28] Hassan, K. H. (2006). Geographical Analysis of Drained Marshes in Southern Iraq (in Arabic). Dhi Qar University Journal 2 (1).

https://www.researchgate.net/publication/301790213_Developing_Flood_Dis charge_Capacity_of_Kmait_River.

[29] Hassan, R., Ammar, A., Anwer, H., Al-Ansari, N. and Knutsson, S. 2(019). Reduction in the Storage Capacity of Dokan Dam Reservoir. In Proceedings of the 1st Springer Conference of the Arabian Journal of Geosciences (CAJG1), Tunisia 2018, 5:429-32. https://doi.org/10.1007/978-3-030-01572-5_101.

[30] Hassun, Sara Abdullah, and Abdul, Amer Abbas Al-Haialy (2015). Regional Planning and Rural Development in Khanaqin District Farmland (in Arabic). Diayal, No. 67.

[31] Industry, Directorate General of (1957). Tharthar Salinity, a Report Submitted to Development Board.

[32] Iraq, Nature (2014). The New Eden Project: Executive Summary 2003-2013. http://www.natureiraq.org/uploads/5/2/9/9/52997379/report_new_eden.pdf.

[33] Issa, Issa (2015). Sedimentological and Hydrological Investigation of Mosul Dam Reservoir. Lulea.

https://www.researchgate.net/publication/275034112_Sedimentological_and_ Hydrological_Investigation_of_Mosul_Dam_Reservoir.

[34] Kelley, J. R., Lillian, D. Wakeley, S., Broadfoot, W., Monte, L P., Christian, J. Mcgrath, T. E, Mcgill, J., Jorgeson, D. and Talbot, C.A. (2007). Geologic Setting of Mosul Dam and Its Engineering Implications. US Army Corps of Engineers.

https://www.researchgate.net/publication/235208177_Geologic_Setting_of_ Mosul_Dam_and_Its_Engineering_Implications. 
[35] Li, J., Ameen, A.M.S., Mohammad, T.A., Al-Ansari, N. and Yaseen, Z.M. (2018). A Systematic Operation Program of a Hydropower Plant Based on Minimizing the Principal Stress: Haditha Dam Case Study. Water (Switzerland) 10 (9): 1-19. https://doi.org/10.3390/w10091270.

[36] Macdonald, Sir M. (1967). East Gharraf Irrigation and Drainage Project: Planning Report.

[37] Macdonald, Sir M. (1971). Badra, Jassan, Zurbatyeh Irrigation Project: Design Report.

[38] Mahmoud, A. H. (2011). Valuating the Feasibility Study of Hilla - Kifl Irrigation Project. Iraqi Journal of Civil Engineering 11.

[39] Ministry of Irrigation (n.d.). Euphrates East Drain Project, Contract 1, Volume II.

[40] Ministry of Irrigation (1984). 7 Nissan Project, Phase I, Volume 3.

[41] Ministry of Irrigation (1988). A Report of the Year 1988 Flood.

[42] Ministry of Irrigation (n.d.) (2001). The Implemented Projects from 1/1/1996 to $1 / 6 / 2001$.

[43] Mosul, University of (1978). Hawija Project: From Services to Production (in Arabic).

[44] Mousa, Z. A. (2017). Geographical Evaluation of Irrigation and Drainage Network in Babylon Governorate (in Arabic)."Journal of the College of Education and Humanitarian Sciences/University of Babylon 32.

[45] Ministry of Water Resources (n.d.). Ministry of Water Resources Official Page on Facebook. Accessed June 14, 2019. https://www.facebook.com/waterresources $2 /$ ? _ $\mathrm{tn} \_=\mathrm{kC}-$ R0.g\&eid=ARB_vikp82C0hDpmLSD5DywN37xKMKk8imYIn2PhYPeUh2 KW2Kj_a4mh-PBME0E2_ymGK4R0-

TzxN71H\&hc_ref=ARTjh7GWKUgcCsFz1D3H1C92eUW9dbL4UdO_cA_ vttchORbUsIHWsOhQy4rbVssSgrk\& fref $=$ nf \&_xts_[0]=68.ARAJtjsqk9j7 gRAv.

[46] Nedeco (1978). Abu Ghrain Project: Planning Report, Volume IV.

[47] Binnie and Partners(1962). Kirkuk Irrigation Project: Feasibility Report.

[48] Ministry of Water Resources (2005). The Encyclopedia of Irrigation in Iraq, February 1918-February 2005.

[49] Saeed, F. H. (2018). Optimum Utilization of Iraqi Eastern Streams. In Water Scarcity in Iraq, Current Situation and Future Challenges. Iraqi Forum for Intellectuals and Academics. https://iraqi-forum2014.com/optimumutilization-of-iraqi-eastern-streams/?lang=en.

[50] Saiid, M. (1978). The Ancient Sites in the Basin of the Hadithaa Dam on the Euphrates. 
[51] Saleh, S. A., Omar, R. A., and Abdulsalam, M. S. (2017). Innovated Method to Estimate the Water Income in the Section of Tharthar Valley near the Site of Hatra Proposed Dam 22 (6): 88-102. https://www.researchgate.net/publication/318457144_Innovated_Method_to_ Estimate_the_Water_Income_in_the_Section_of_Tharthar_Valley_near_the Site_of_Hatra_Proposed_Dam.

[52] Sissakian, V. (2011). Genesis And Age Estimation Of The Tharthar Depression, Central West Iraq. Iraqi Bulletin of Geology and Mining 7 (January):pp.47-62.

https://www.researchgate.net/publication/274633668_GENESIS_AND_AGE _ESTIMATION_OF_THE_THARTHAR_DEPRESSION_CENTRAL_WES T_IRAQ.

[53] Sissakian, V., Adamo, N., Al-Ansari, N., Knutsson, S. Laue, J. and Elagely, M. (2018). A Comparative Study of Mosul and Haditha Dams, Iraq: Geological Conditions. Journal of Earth Sciences and Geotechnical Engineering 8 (March). https://www.researchgate.net/publication/323486340_A_Comparative_Study _of_Mosul_and_Haditha_Dams_Iraq_Geological_Conditions.

[54] SMEC (2006). Dokan and Derbendikhan Dam Inspections. http://documents.worldbank.org/curated/en/846331468044054012/E15370Do kan0an1am0Inspection0Report.doc.

[55] Sousa, A. (1944). Euphrates Basin, and Habbaniyah Lake Project (in Arabic). http://hdl.handle.net/2333.1/fj6q5fx4.

[56] Sousa, A. (1946). Irrigation Development in Iraq.

[57] Sousa, A. (1947). Major Irrigation Projects: The Reservoir of Shweicha Marsh.

[58] Sousa, A. (1948). Irrigation of Samarra during Abbasid Khalef: Part 1 (in Arabic).

[59] Sousa, A. (1966). Baghdad Floods in the History: Volume 3 (in Arabic).

[60] Sousa, A., and Vahe, S. (1965). A Report about Potential Irrigation Projects in Northern Areas: Part 1 (in Arabic).

[61] Technopromexport (1978). Haditha Project on the Euphrates River-Technical Design, Volume I: Summary.

[62] Trevi Group Website (n.d.). Accessed June 1, 2019. http://www.trevigroup.com/en/.

[63] USACE (2003). Iraqi Dam Assessments.

[64] Water Resources Directorate in Babylon (n.d.).

[65] Wilcox, William (1917). Irrigation of Mesopotamia.

[66] Zubaidy, R. Z. Al., Hayder, A. A. T., and Khafaji, S.A. (2016). Developing Flood Discharge Capacity of Kmait River Developing Flood Discharge Capacity of Kmait River. March 2008. https://www.researchgate.net/publication/301790213_Developing_Flood_Dis charge_Capacity_of_Kmait_River. 